\title{
Inflammatory cytokines in obstructive jaundice
}

Citation for published version (APA):

Bemelmans, M. H. A. (1994). Inflammatory cytokines in obstructive jaundice. [Doctoral Thesis, Maastricht University]. Datawyse / Universitaire Pers Maastricht. https://doi.org/10.26481/dis.19940527mb

Document status and date:

Published: 01/01/1994

DOI:

10.26481/dis. $19940527 \mathrm{mb}$

Document Version:

Publisher's PDF, also known as Version of record

\section{Please check the document version of this publication:}

- A submitted manuscript is the version of the article upon submission and before peer-review. There can be important differences between the submitted version and the official published version of record.

People interested in the research are advised to contact the author for the final version of the publication, or visit the DOI to the publisher's website.

- The final author version and the galley proof are versions of the publication after peer review.

- The final published version features the final layout of the paper including the volume, issue and page numbers.

Link to publication

\footnotetext{
General rights rights.

- You may freely distribute the URL identifying the publication in the public portal. please follow below link for the End User Agreement:

www.umlib.nl/taverne-license

Take down policy

If you believe that this document breaches copyright please contact us at:

repository@maastrichtuniversity.nl

providing details and we will investigate your claim.
}

Copyright and moral rights for the publications made accessible in the public portal are retained by the authors and/or other copyright owners and it is a condition of accessing publications that users recognise and abide by the legal requirements associated with these

- Users may download and print one copy of any publication from the public portal for the purpose of private study or research.

- You may not further distribute the material or use it for any profit-making activity or commercial gain

If the publication is distributed under the terms of Article $25 \mathrm{fa}$ of the Dutch Copyright Act, indicated by the "Taverne" license above, 
INFLAMMATORY CYTOKINES IN OBSTRUCTIVE JAUNDICE 


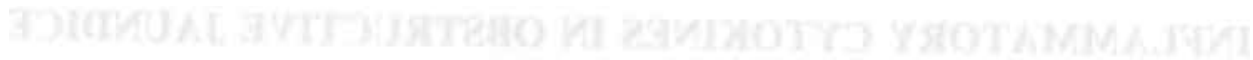




\title{
PROEFSCHRIFT
}

ter verkrijging van de graad van doctor aan de Rijksuniversiteit Limburg te Maastricht, op gezag van de Rector Magnificus, Prof. dr. H. Philipsen, volgens het besluit van het College van Dekanen, in het openbaar te verdedigen op vrijdag, 27 mei 1994 om 16.00 uur

\author{
door \\ Marcus Henricus Adrianus Bemelmans. \\ geboren op 7 februari 1964 te Maastricht
}

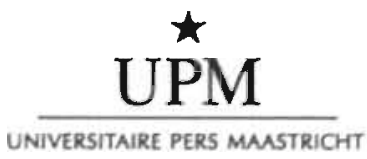




\section{Promotores}

Prof. dr. D.J. Gouma

Prof. dr. P.B. Soeters

\section{Co-promotor}

Dr. W.A. Buurman

\section{Beoordelingscommissie}

Prof. dr. R.W. Stockbrügger (veorzitter)

Prof. dr. L.A. Aarden (Vrije Universiteit)

Prof. dr. P.W. de Leeuw

Prof. dr. F.C.S. Ramaekers

Prof, dr. G.N.J. Tytgat (Universiteit van Amsterdam)

Prof. dr. E.F.M. Wouters

O M.H.A. Bemelmans, Maastricht 1994

CIP-DATA KONINKLIJKE BIBLIOTHEEK, DEN HAAG Bemelmans, Marcus Henricus Adrianus

Inflammatory cytokines in obstructive jaundice / Marcus Henricus Adrianus Bemelmans. - Maastricht: Universitaire Pers Maastricht. - Ill.

Thesis Maastricht. - With ref. - With summary in Dutch. ISBN 90-5278-137-0

Subject headings: jaundice / cytokines

Layout: Karin Scheele, A Point, Maastricht

Production: Datawyse, Maastricht / Krips Repro Meppel 
In memory of my brother René To my parents 


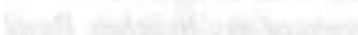

年

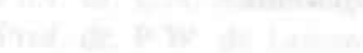

arara 


\section{CONTENTS}

CHAPTER 1. Preface

Introduction:

1. Inflammation

2. Inflammatory aspects

2.1 Inflammatory aspects of gastro-intestinal diseases

2.2 Inflammatory aspects of obstructive jaundice

3. Cytokines

4. Interleukin-6

5. Tumor Necrosis Factor

6. Soluble TNF Receptors

7. Cytokines

7.1 Cytokines in gastrointestinal diseases

7.2 Cytokines in obstructive jaundice

8. Aim of the thesis

CHAPTER 2. Introduction to and discussion of the experimental work 19 References to chapters 1 and 2

CHAPTER 3. Cytokines TNF and IL-6 in biliary obstruction in mice

CHAPTER 4. The effect of anti-TNF treatment on circulating Tumor Necrosis Factor and mortality after surgery in jaundiced mice

CHAPTER 5. Increased levels of TNF and soluble TNF receptors in biliary obstruction in mice; prognostic importance of sTNFR-P55 and sTNFR-P75 but not of TNF for mortality after surgery

CHAPTER 6. Influence of nephrectomy on Tumor Necrosis Factor clearance in a murine model 
CHAPTER 7. Tissue distribution and clearance of soluble murine TNF receptors in mice

CHAPTER 8. LPS induced sTNF-Receptor release in vivo in a murine model: investigation of the role of TNF, IL- $1, \mathrm{LIF}$, and IFN- $\gamma$

CHAPTER 9. Evidence that T-cell activation by anti-CD3 induces soluble TNF Receptor release in a murine model: effect of pentoxifylline, methylprednisolone, antiTNF, and anti-IFN $\gamma$

CHAPTER 10. Increased plasma levels of soluble Tumor Necrosis Factor receptors in sepsis syndrome: correlation with plasma creatinine

CHAPTER 11. Summary / Samenvatting

Dankwoord 165

Publications 


\section{Chapter 1 \\ PREFACE AND INTRODUCTION}

\section{PREFACE}

Surgical procedures are generally associated with local and more general inflammatory changes as a response to the surgical trauma (1). These inflammatory changes reveal a good correlation with the septic complications after surgical procedures. Especially the septic complications are responsible for the high morbidity and mortality after surgery (2). Thus far, monitoring and detection of inflammation was of great importance for the surgeon to prevent these septic complications. Moreover, more knowledge of the pathophysiology which is underlying the complications associated with inflammation after surgery could lead to a better understanding and eventually to a more successful prevention of such complications.

To assess the presence of inflammation, surgeons for a long time had only the possession over the classical hallmarks of inflammation such as "dolor, rubor, calor, tumor, and functio laesa". In the early days of modern surgery, sedimentation rate of erythrocytes (ESR), and leucocyte count and differentiation rate became available for monitoring inflammation which was followed more recently by the recognition of acute phase proteins (APP). The levels of the APP were upregulated in response to trauma, inflammation, burns, and sepsis and their increases are related to the magnitude of the trigger $(3,4)$. Nevertheless, the earliest increase in A.PP is observed approximately 6 hours after the initial event (CRP, SAA) with peak levels after 24-48 hours. Other acute phase proteins are much slower and the first response is observed after 24-48 hours ( $\alpha$-acid glycoprotein, C3, C4) (5). Because of this late increase, these measurements added limited extra information to the clinical view of the surgeon. Moreover, they were of little value for a better understanding of the pathophysiology of the inflammatory response.

In the mid-1960s, several biological markers derived from lymphocytes were discovered in biological fluids which regulate growth and function of a variety of leukocytes. In the past decades it became evident that these regulatory proteins were member of a large family of proteins that regulate various immune mechanisms, which were called cytokines. A definition for cytokines was proposed by Balkwell and Burge in 1989: "Cytokine is one term for a group of protein cell regulators, variously called lymphokines, monokines, interleukins, and interferons, which are produced by a wide: variety of cells in the body, play an important. role in many physiological responses, are involved in the pathophysiology of a range of diseases, and have therapeutic potential" (6). 
Cytokines were suggested to play an important role in inflammatory processes, for example during surgery. It was hypothesized that during suigery a selective hypoperfusion of the bowel was present, leading to a local ischemia. The local ischemia lead to a damage of the mucosal integrity and eventually to activation of the immune system and subsequent cytokine release. At this moment many cytokines are known: Interleukin-1 (LL-1) till IL-13, interferons, growth inhibitory/stimulatory cytokines and chemotactic cytokines (7-12). Although their functional properties are as yet far from being elucidated, it is clear that cytokines are very powerful and specific proteins. They exert their action by binding to specific high affinity receptors and can already be active at picomolar concentrations. The cytokines IL-1, IL-6 and Tumor Necrosis Factor (TNF), also called inflammatory cytokines, have been shown to play an important role in septic shock $(13,14)$. In line with this observation, antibodies against these cytokines or receptor antagonists have been shown to protect experimental animals against a lethal endotoxic shock, supposedly because of inactivation of TNF (15-19). An interesting phenomenon is the observation that several cytokine receptors, which are present on cell membranes, can be liberated in inflammatory situations and circulate thereafter in soluble form (20). They can bind to cytokines in the circulation and inactivate the proteins. The latter property was supported by data which showed that injection of soluble TNF receptors protected against a lethal endotoxic shock in mice, supposedly because of inactivation of TNF (21). However, they can also prolong the presence of their ligands in the circulation by stabilization of the complex (22).

Knowledge of such cytokines and cytokine receptors could give more insight into the pathophysiology of inflammatory diseases and more specifically into the pathophysiology underlying the complications observed after obstructive jaundice, a disease state in which we are mainly interested in this thesis. Moreover, cytokine measurements could be very useful in monitoring effectiveness of interventions in these diseases which are still difficult to assess at this moment.

Our interest in obstructive jaundice originated from the fact that surgery in patients with obstructive jaundice is associated with an increased morbidity and mortality (23. 25 ) and until now, still no parameter has been found which is uniformly useful for prediction of the complication in this disease state (26). The increased complications rate arising after surgery in these patients is subscribed to the presence of an inflammatory status. The inflammatory status is caused by endotoxemia which is present in jaundiced patients as has been suggested by previous investigators $(27,28)$. This endotoxemia is supposed to be the result of the absence of bile acids in the bowel. Normally, the bile acids disperse the endotoxins in the bowel in non toxic subunits. Due to their absence in the bowel during obstructive jaundice, endotoxins can enter the bloodstream (29-31). The endotoxins lead to the release of inflammatory cytokines in to the circulation. The cytokines play an important role in the endotoxin induced changes such as hypotension, fever, malaise and eventually shock.

Therefore, in this thesis, we studied the regulation of cytokines and their receptors in inflammation in general and more specific in obstructive jaundice. 


\section{INTRODUCTION}

\section{Inflammation}

Inflammation is a reaction which is meant to attack intruding agents and to prevent spread of harmful agents over the complete body. Furthermore, it should protect against infection and remove the debris from the damaged tissues. Nevertheless, inflammation is not always as beneficial as one would expect from a teleological point of view. There is substantial evidence that in diseases associated with high levels of inflammatory mediators, negative or harmful effects of these mediators can be observed (32).

One of the most extreme examples of this fact is that administration of lipopolysaccharide (LPS; also called endotoxin, a cell wall component of gram negative bacteria) and bacteria induce a shock-like syndrome which can eventually lead to development of multiple organ failure (MOF) and death (15-17,19,21).

Inflammatory responses are governed by activation of an inflammatory cascade including activation of endothelial cells, macrophages, monocytes, and other tissue cells, all of which will lead to alterations in eicosanoids, kinins and activation of the complement system and to the release of inflammatory cytokines such as IL-1, TNF, IL-6 and IFN- $\gamma(4,5)$. These cytokines on their tum will induce a secondary inflammatory reaction of the host reflected by an increase in inflammatory markers like A.P., proteinases, and glucocorticoids. In parallel, dependent on the extent of the inflammatory response, several nutritional changes can take place such as enhanced amino acid uptake, decreased iron and zinc levels $(33,34)$ and increased levels of copper (34), phenomena which are still not completely understood.

All inflammatory mediators and reactions are interconnected in one or another way, although the mechanisms are as yet not completely elucidated. This seems in line with observations showing that interventions in various parts of the inflammatory cascade such as the cascade of cytokines, eicosanoids, and coagtiation can prevent the deleterious effects of an exaggerated inflammatory responses and prevent death in otherwise lethal situations $(15-19,35)$.

As mentioned in the preface, inflammatory responses appear to have also harmful effects in surgical patients such as patients with obstructive jaundice and the outcome after surgery in these patients is strongly influenced by these inflammatory responses $(25,27,28)$.

\section{$2 \quad$ Inflammatory aspects}

\subsection{Inflammatory aspects of gastro-intestinal diseases}

Gastrointestina! (GI) diseases often reveal characteristics which fit with the description of inflammation. The inflammatory reaction in GI diseases has been studied extensively, especially in the case of inflammatory bowel diseases like Ulcerative Colitis and 
Crohn's disease (36-42). Nevertheless, there is also a growing interest for inflammatory aspects of other GI diseases such as hepatitis, liver cirrhosis and for the inflammatory derangements during diseases which lead to obstructive jaundice $(24,25,27,28)$.

In all GI diseases, the barrier function of the intestine plays a central role. In physiological circumstances, this barrier prevents translocation of the microbial flora and microbial products present in the GI tract into the portal circulation. In this mechanism also bile acids play a prominent role, since they disperse endotoxins, present in the GI tract into non-toxic subunits (29-31). It is evident that diminishment of this barrier function by GI diseases will lead eventually to inflammation and decreased host resistance (43-47).

\subsection{Inflammatory aspects of obstructive jaundice}

While some GI diseases, such as Ulcerative Colitis and Crohn's disease affect directly the intestine through their local inflammatory derangements, obstructive jaundice influences the intestinal homeostasis indirectly by interfering with the bile acid release with as a consequence inadequate dispersion of endotoxins in the gut. The ultimate result is translocation of endotoxins which will induce overflow and leakage of endotoxins into the portal circulation. Normally the endotoxins present in the portal tract, are inactivated by the Kupffer cells $(48,49)$. Kupffer cells can remove substances from the circulation by phagocytosis or pinocytosis, depending on the size of the particles. Moreover, Kupffer cells are more efficient in removing endotoxins from the circulation compared to other macrophages (50). However, when endotoxin inactivation by the Kupffer cells is inadequate which is the case diring obstructive jaundice, endotoxins will enter the systemic circulation, with all its consequences. In line with the assumption that bile acids are essential in regulation of endotoxin homeostasis, administration of sodium deoxycholate to patients with obstructive jaundice resulted in reduced endotoxemia and absence of renal impairment (51). Moreover, administration of oral bile salts or infusion of polimixin B to rats with experimental obstructive jaundice before oral administration of endotoxins markedly reduced mortality compared to the control rats which did not receive the bile salts or polimixin B, supporting the important role of bile acids and endotoxins $(52,53)$.

The presence of these endotoxins in the circulation, a situation which can be mimicked. by administration of endotoxins to healthy volunteers and experimental animals, will induce the release of several inflammatory mediators amongst others cytokines such as IL-1, Il-6 and TNF, which on their turn will initiate APP release (54-56). The fore mentioned cytokines are very powerful proteins. This is illustrated by the fact that injection of TNF or IL-I into experimental animals can induce a lethal shock syndrome, although TNF is a more potent cytokine in this respect than $\mathrm{L}-1$ (57). The discovery of these cytokines as mediators of inflammation during the last decades offered a major step forward for the unravelling of the pathophysiology of the GI diseases in general and for clarifying of the pathophysiology underlying obstructive jaundice specifically. 


\section{Cytokines}

The discovery of cytokines is actually the result from research of four different groups of investigators (58). The first group is the group of Lymphokine Research, the second group is the Interferon group, the third group is the group studying Hematopoietic Growth Factors, i.e. colony stimulating factors and the fourth group was arising from the researchers interested in the Growth Factors acting on non-hematopoietic cells.

Lymphokine research started in the beginning of the sixties when researchers became interested in factors which they called lymphokines: "cell-free soluble factors (responsible for cell-mediated immunological reactions), which are generated during interaction of sensitized lymphocytes with specific antigen" (59). Among the lymphokines recognized was $I L-2$, a product of activated lymphocytes, which supports growth of activated lymphocytes (60).

The first lymphokine obtained from monocytes/macrophages was Tumor Necrosis Factor (TNF) (61). TNF was shown to affect tumor growth as well as induce cachexia in experimental models, as will be discussed below. Another monocyte derived cytokine was Lymphocyte Activation Factor (LAF), nowadays known as IL-1. IL-1 was originally detected as a mitogenic signal for thymocytes derived from cells from human peripheral blood (62). Nowadays it is evident that it is a central mediator of inflammatory responses with immunological properties (natural killer activity, T-cell activation, B-cell activation), pro-inflammatory properties (fever, sleep, anorexia, endothelial cell activation, death, shock neutrophil tissue infiltration, increased adhesion molecule expression, amino acid turnover, cyclo-oxygenase and lipoxygenase gene expression etc.) and protective effects (hyperoxia, lethal radiation, malaria, bacterial infections, inflammatory bowel disease and histamine release) $(60,63)$.

The Interferon Group consisted mainly out of virologists. Isaacs and Lindeman described interferon as a factor which was produced by cells after infection with a virus and which could transfect cellular resistance to certain other viruses ("nonimmune interferons") (64). A number of years later it was discovered that also activated T-lymphocytes produce an interferon related protein (65). The protein, which affected immune reactions, is nowadays known as interferon- $\gamma$ ("immune interferon") (66). The third source of cytokine research has evolved from research on Colony Stimulating Factors (CSF), which were acting on the hematopoietic cells (97). Factors which can be rated amongst CSFs are multi-CSF (IL-3), granulocyte/ macrophage specific CSF (GM-CSF), macrophage specific CSF (M-CSF), and granulocyte specific CSF (G-CSF). Their most important function is to support proliferation and differentiation of the hematopoietic cells. The fourth research group studied Growth Factors acting on non-hematopoietic cells among which are rated epidermal growth factor (EGF), platelet derived growth factor (PDGF) and fibroblast growth factor (FGF) (58). One of the last proteins discovered by this group is transforming growth factor (TGF) (68). TGF is present in two forms (TGF- $\alpha$ and TGF- $B$ ) and has pluriform properties ranging from immunosuppression to the induction of deposition of extracellular matrix 
(69-73). These properties makes the cytokine extremely interesting to the surgeon since the immunosuppression which is observed after surgery but also in other disease states could be related to increased levels of TGF- $B$. Indeed, recent data in a murine model showed that following hemorrhage TGF- $\beta$ release is contributing to the immunosuppression observed in these mice (74). It is of interest that in jaundiced patients increased levels of TGF- $B$ are observed. Furthermore, increased levels of TGF- $B$ have been shown to be related to the vascular restenosis after balloon angioplasty (75). Scarring and adhesion formation has also been shown to be controlled by TGF- $B$ $(76,77)$. Treating wounds in experimental animals with anti TGF- $B$ resulted in the same strength of the tissue after healing, but prevented formation of scar tissue. These properties make this cytokine extremely interesting for future research in surgery.

The wide variety in names for the above described proteins, which were actually closely related to each other, resulted in 1974 in the proposition to call these proteins cytokines (78), a name which is nowadays commonly accepted. Nevertheless, the nomenclature is far from ideal, especially since 2-3 new cytokines per year are discovered and the names do not cover their functions. In this thesis we will specifically focus on the inflammatory cytokines IL-6 and TNF and its soluble receptors.

\section{Interleukin-6 (IL-6)}

11-6 is a cytokine which has been termed by several names: interferon- $B 2,26-k D a$ protein, hepatocyte stimulating factor, B-cell stimulatory factor 2 , hybridoma/ plasmocytoma growth factor, and monocyte/granulocyte inducer type II (79.84). Since molecular cloning revealed that all these proteins were identical, it was proposed in 1988 to call the protein Interleukin-6 (IL-6) $(79,80,82,83,85)$. IL-6 is a cytokine with plurifold properties and with a molecular mass of approximately $26 \mathrm{kDa}(79,82)$. The human IL-6 molecule consists out of 212 amino acids, including 2 potential $\mathrm{N}$ glycosylation sites and is located on chromosome 7. Comparison of human $\mathrm{L}-6$ with murine and rat IL-6 revealed a homology at DNA level of $65 \%$ and $68 \%$ resp., while at protein levels these figures were $42 \%$ and $58 \%(82,83)$. Especially the four cysteine residues of the IL-6, molecule are very good conserved between the species. This suggests that despite the relative differences at DNA levels between different species, the iertiary structure is conserved. Since human IL-6 is active on murine cells, this leads to the assumption that the $\mathrm{NH}_{2}$ terminal region of the molecule, where substantial species differences are observed, is not essential for biological function $(83,86)$. The receptor for IL-6 (IL-6R) consists out of 468 amino acids, and the molecular weight of this glycoprotein is approximately $80 \mathrm{kDa}(82,83,87,88)$. The receptor is present on T-cells, monocytes and macrophages, and is responsible for binding of the IL-6. molecule $(82,83,87,88)$. Nevertheless, the signal transduction is not controlled by the intracellular domain of the $\mathrm{IL}-6 \mathrm{R}$, since absence of this domain still results in activation of cells. It was discovered that another protein, gp 130 is responsible for signal transduction by forming a high affinity complex together with the IL-6R $(82,83,89)$. The soluble receptor for $\mathrm{LL}-6$ has been observed in the urine indicating that the 
receptor is supposedly released into normal body fluids during physiological circumstances, a phenomenon which is also the case for the soluble receptor of TNF, IFN- $\gamma$ and IL-1 (90-96).

IL-6 gene expression is increased in almost every human organ after trauma (79). Moreover, IL-6 gene expression can be enhanced by several cytokines such as TNF, IL-1 and PDGF, but also by virus infections and bacterial products such as LPS $(83,97)$. The cytokine can be produced by T-cells, fibroblasts, monocytes, and endothelial cells upon stimulation with a variety of stimuli. These stimuli include T-cell mitogens such as PHA or ConA, various viruses including human immunodeficiency virus, IL-1, TNF, IL-2, IFN-B, PDGF, protein kinase C, calciumionophore A23187, and LPS $(82,83,85)$. Injection of the latter into experimental animals but also into healthy volunteers resulted in the appearance of $\mathrm{IL}-6$ in the circulation, reaching maximal levels after 2-3 hours (54).

As the wide variety in original names already suggests, IL-6 is a cytokine with multiple functions. $\mathrm{IL}-6$ acts on cells involved in hematopoiesis like megakaryocytes, myeloid leukemic cells and stem cells. Moreover, IL-6 injection to mice or monkeys increased platelet numbers together with an increased size of megakaryocytes $(98,99)$. These facts suggest that IL- 6 may be effective clinically for the treatment of treatment induced thrombocytopenia.

IL-6 is together with TNF, IL-1, and LIF an important regulator of the acute phase response $(100,101)$. Increased IL-6 synthesis has been reported in many diseases. These diseases can be divided into 4 major groups: The polyclonal B cell activation or autoimmune diseases (Rheumatoid arthritis, AIDS, Cardiac myxoma, Castelman's disease, thyroiditis, and insulin dependent diabetes mellitus), Malignancies (lymphoma, leukemia, plasmocytoma, myeloma, Hodgkin's disease, renal cell carcinoma), proliferative diseases ( psoriasis, glomerulonephritis) and others (sepsis, burns, morbus. Paget and inflammatory diseases) (82). Moreover, IL-6 was shown to be a good prognostic marker for lethality not only in a murine septic shock model (102), bur also in septic patients (103). In line with these results, recent data showed that injection of antibodies against IL-6 prevented mortality after an injection with a lethal dose of endotoxin in a murine model (17). Surprisingly, injection with high doses of IL-6 in experimental animals is not lethal, which makes the exact role of IL-6 in the pathophysiology of sepsis difficult to understand.

It has been reported that IL-6 shows a good correlation with CRP, immunoglobin production and with thrombocytosis in patients with severe burns (104). Sequential serum IL-6 measurements can be used to differentiate rejection from nephrotoxicity' in rena! allograft patients (105). Furthermore, it was reported that the IL-6 increase after trauma or LPS injection was much faster than that of CRP, making IL-6 a more helpful tool for estimation of the inflammatory status than CRP $(55,56,95)$. Therefore, IL-6 is especially helpful as an indicator in situations where an acute trauma, inflammation or 
endotoxemia is present. The latter property is extremely helpful in the case of obstructive jaundice which is accompanied by endotoxemia.

\section{TNF}

The actual discovery of TNF goes back to the end of the 19th century (1893), when William B. Coley discovered that erysipelas possessed a powerful antagonistic effect. against sarcomas (106). He observed in a patient with an inoperable sarcoma of the neck that the tumor completely disappeared after two consecutive attacks of erysipelas and that the patient was alive and in good health seven years later. His conclusion at that time was that the curative action of erysipelas was systemic and most likely due to the toxic products of the streptococci. In fact, Dr Coley was at that very moment probably witnessing the effects of TNF induced by the toxins which were released in the course of the erysipelas attacks. After this observation, Coley started experiments in which he injected patients with irresectable tumors with toxins obtained from streptococci (107). However, these toxin injections were harmful and therefore he continued with research aimed at reduction of the toxicity of his so-called Coley's toxin.

In 1962 O'Malley et al reported that serum of endotoxin (LPS) injected mice could induce hemorrhagic necrosis in tumors (108). Similar observations were done by Carswell and Old et al in 1975 (61). They observed that serum of mice primed with bacillus Calmette Guérin foliowed by LPS injection could induce necrosis in transplantable tumors in other littermates. They called the protein (which was later shown to be a product of mononuclear phagocytes) in the circulation responsible for this phenomenon, Tumor Necrosis Factor or TNF. In 1984 TNF was purified and characterized by Pennica et al. (109).

Somewhat years later, a macrophage derived factor was isolated from endotoxin injected mice which caused suppression of lipoprotein lipase (LPL). Moreover, injection of this protein into healthy mice resulted in cachexia. The protein, purified by Beutler et al. and produced by macrophages stimulated with LPS, was called cachectin by the investigators $(110,111)$.

By comparing the biological activities and next sequencing both proteins, Beutler and Cerami showed in 1985 that mouse cachectin and human TNF were similar proteins (112). The gene of the TNF- $\alpha$ protein is located on the short arm of chromosome 6 , in close proximity to the major histocompatibility complex (MHC). It is closely linked to another cytokine, which was discovered in 1968 by two groups: Ruddle \& Waksman and Granger \& Williams $(113,114)$. The first investigators called the protein Cytotoxic Factor while the second group investigators named it Lymphotoxin. In 1987 it became evident that TNF and Lymphotoxin were 35\% homologous (115), that they bound to the same receptors and shared many activities like killing of L929 cells, induction of necrosis in Meth A sarcomas and activation of PMN's (116,117). These observations 
prompted them to change the name of Lymphotoxin into TNF-B and the name of TNF in TNF- $\alpha$.

Human TNF is produced as a pro-hormone of 233 amino acids. The propeptide is processed to a mature secreted form of 157 amino acids by cleavage of an atypical residue of 76 amino acids (90). The latter residue is strongly conserved between the different species which suggests an important function for this part of the molecule (90), although the exact function is not yet elucidated. After cleavage of the precursor molecule, the $17 \mathrm{kDa}$ mature molecule is synthesized. Nevertheless, there is also a 26 $\mathrm{kDa}$ membrane associated form of TNF reported, which can activate cells locally by binding to their TNF receptors $(118,119)$ ). It is thus far not clear, whether all secreted mature TNF is derived from the membrane bound form or that it can be secreted also directly without formation of membrane bound TNF. Recent studies have indicated that TNF is circulating in a trimeric form with a sort of "jelly roll" motif that resembles the structure of several viruses $(120,121)$.

TNF is produced by several cells such as T-lymphocytes and mononuclear phagocytes in response to diverse stimuli such as T-cell activation, TNF itself, immune complexes, C5a and LPS $(13,90,122-125)$. TNF is a predominant mediator in metabolic changes observed after LPS injection (126). It affects vascular endothelium as well as local and circulating leukocytes. Moreover, TNF induces a cascade of inflammatory reactions as well as production of other cytokines $(90,127)$. TNF incorporates many beneficial properties especially when TNF is restricted to local areas (123). These effects include the promotion of margination of leukocytes at the inflammatory site to regulate host defense; however, when TNF is reaching the systemic circulation a syndrome can develop which can not be distinguished from the septic shock syndrome, eventually leading to multiple organ failure and death $(13,32,90,127-129)$.

Another characteristic of TNF is its cytotoxicity for tumor cells, especially in combination with IFN- $\gamma(90,130)$. However, one disadvantage of TNF is its high toxicity, which reduces the possibility of using the cytokine systemically in a clinical situation. Nevertheless, in patients with sarcoma or melanoma of the extremities, the combination of TNF, IFN- $\gamma$ and Melphalan given via an isolated limb perfusion, thereby avoiding the systemic effects, is reported to be extremely effective for eradication of the tumor (130). Another possibility of using TNF is the latest discovery from the laboratory from Prof. Fiers. They developed human TNF mutants that reacted with the human TNF Receptor-P55 (TNFR-P55, one of the two TNF receptors), but largely lost the ability to bind to human TNF Receptor-P75 (TNFR-P75). Their results showed that the mutant R32W, by triggering TNFR-P55 retained its cytotoxic activity on the human adenocarcinoma cell line HT-29. Moreover, the mutant R32W was almost not toxic for normal mice while it still revealed antitumor activity in vivo (131). Although these data are still in experimental situation and although it has to be studied whether the antitumor activity of the mutants is also present in primates and humans in vivo, the first results are very promising. 
Furthermore, TNF is suggested to play an important role in many diseases. In patients with adult respiratory distress syndrome, significant amounts of TNF were observed in the bronchopulmonary secretions whereas no TNF was detected in samples of control patients (128). The group of Waage et al. obtained data showing an association between serum TNF levels and mortality in patients with meningococcal disease (32). In line with the fact that TNF can be harmful in certain situations, immunization against TNF using anti-TNF antibodies prevented endotoxin induced mortality in several animal models $(19,129,132)$. On the basis of these results, the antibody was tested in clinical situations. However, thus far data which support the beneficial effect of the antibody in clinical situations are lacking, possibly because in those situations the pathology is more diverse and single cytokine therapy is not sufficient. Moreover, in an experimental bacterial sepsis model of cecal ligation and puncture (CLP), TNF was shown to have beneficial effects and administration of anti-TNF antibodies resulted in death within 1-3 days (133). The latter data suggested that TNF has a physiological role in the CLP model to localize the inflammation. Recent data showed that in murine Candida Albicans infection, TNF also might serve a protective role (134).

As already mentioned, TNF can be induced in experimental animals by injecting animals with LPS. However, TNF measurements do have their drawbacks since the duration of TNF release in response to endotoxin is short, which implicates that presence of TNF can easily be missed. Furthermore, since measurement systems for TNF are not identical (bioassay, ELISA, RIA), there are massive differences between their results, making the interpretation of the data not always easy $(135,136)$. For example, bioassays detect only biologically active proteins and proteins coupled to soluble receptors are not "recognized". In ELISA systems, detection is dependent on the epitope recognition of the antibody. If the recognition of the detecting antibody is not hindered by eventual binding proteins coupled to the protein which has to be measured, this fact will lead to higher levels of these proteins consisting not only out of biologically active but also immunologically detectable proteins. Because some groups use assays that detect biologically active TNF while others use assays which measure immunologically detectable TNF, it is essential to investigate which detection systems are used by the different research groups before interpretation of their data takes place.

In conclusion, TNF is a cytokine with plurifold properties and with very potent effects, harmful as well as beneficial; the exact regulation and function however, is not completely elucidated.

\section{Soluble TNF Receptors}

TNF receptors are present on the majority of cells (90), although there are a few exceptions such as erythrocytes and unstimulated T-lymphocytes. The amount of TNF receptors on the cell membrane is quite heterogenous ranging from 200-10.000 receptors per cell (90). Nevertheless, there is no correlation between the amount of 
receptors on the cell membrane and the response of cells to TNF (137). It was recognized that there were two TNF receptors present on the cell membrane, one receptor of $55 \mathrm{kDa}$ (TNFR-P55) and a $75 \mathrm{kDa}$ receptor (TNFR-P75) (138-144). The observed aminoacid sequence for TNFR-P55 showed a protein of 426 aa with an extracellular domain of 182 aa and an intracellular domain of 220 aa $(90,141,142)$. The TNFR-P75 consisted out of 439 aa, with an extracellular domain of 235 aa and an intracellular part of 174 aa (90). There is no homology between the intracellular parts of the two TNF receptors, which suggests that the signal pathways are different $(90,145)$. Moreover, the structural features which are regulating the functions of the TNF receptors remain to be elucidated.

In the human situation the Kd for TNFR-P55 is $0.5 \mathrm{nM}$ and for TNFR-P75 $0.1 \mathrm{nM}$ (90). Lymphotoxin binds to both receptors $(141,146,147)$. In the murine situation these figures are $0.2 \mathrm{nM}$ for TNFR-P55 and $50 \mathrm{pM}$ for TNFR-P75 (148), although Goodwin et al. propose approximately identical binding affinities for both murine receptors (149).

The mouse TNFR-P55 is $64 \%$ identical to its human counterpart, while TNFR-P75 revealed a homology of $62 \%$. While the homology in TNFR-P55 between the mouse and humans is located in the extracellular domain, the similarities in TNFR-P75 are located in the intracellular domain, which could play a role in the species specificity between both receptors. After all, murine TNFR-P55 has similar affinity for MTNF and hTNF, while the murine TNFR-P75 has only affinity for murine TNF and no affinity for hTNF (149-152).

Recently a murine model was developed which was deficient for TNFR-P55 and which gave the opportunity to elucidate the role of both receptors more specifically. The mice, deficient for TNFR-P55 were resistent to lethal endotoxic shock by L.PS as well as to superantigen shock by s. aureus enterotoxin B (153). However, the mice were more sensitive to infection with L. monocytogenes, thus showing that TNFR-P55 has harmful as well as beneficial effects in vivo.

In vitro data showed that the cytotoxic activity of TNF is probably under control of the TNFR-P55 receptor (154), although Heller et al suggest that also the TNFR-P75 is involved (155). Moreover, it was shown that TNF induced cell adhesion to human endothelial cells was under control of the TNFR-P55 receptor (156). This receptor was also regulating control of NF-kB activation, and expression of intercellular adhesion molecule type 1 (ICAM-1), E-selectin and vascular cell adhesion molecule-1 (VCAM1) (156). However, in a recent report it was shown that both TNFR-P55 and TNFRP75 were involved in regulation of ICAM-1 expression by HL-60 human promyelocytic leukemia cells in vitro (157). Moreover, both TNFR can mediate proliferative responses of human mononuclear phagocytes in response to lectins such as PHA (i58). The TNFR-P75 was recently suggested to play an important role in the induction of cytokine secretion without ligand dependent TNFR-P55 involvement (159). Tartaglia et al. suggested a hypothetical model in which both TNF receptors could mediate 
signals, and that at low TNF concentrations TNFR-P75 is functioning as a catcher by binding TNF and delivering it to the TNFR-P55, which has a lower affinity for TNF (151).

The group of Olsson and Dayer discovered the presence of TNF-binding proteins (TNFBP) not only in the serum and urine of patients on hemodialysis treatment and of patients with fever, but also in the circulation and in the urine of healthy volunteers (160). In 1990 it was discovered by Engelmann et al. that there were two proteins present in the urine which bind TNF, both approximately $30 \mathrm{kDa}$ (139). They appeared to be identical to the TNFBP and to consist out of the extracellular parts of the TNF receptors (161). Therefore they were called soluble TNF Receptors (sTNFR). IIt was demonstrated by Natan et al. that these sTNFR can be liberated from the cell membrane of polymorphonuclear cells by stimulation of these cells by physiological polypeptides (FMLP, C5a, CSF-GM) and pharmacologic agonists (A23187) $(138,162)$. Moreover, new in vitro data revealed that also hypoxia can induce sTNFR release by the human macrophage cell line THP-1 (163). Recent data showed that sTNFR release in the circulation in vivo can be induced by LPS administration into healthy volunteers or baboons and by a severe trauma $(20,164-166)$. In contrast to circulating TNF, systemic sTNFR levels remain high for a longer period of time and therefore they are longer detectable in the circulation. The latter property is of interest, because this fact implicates that sTNFR leveis would be of more value for monitoring inflammatory responses, since TNF levels can easily be missed due to its short presence in the circulation.

So far the exact function of STNFR is not known, although there are several speculations. The sTNFR were suggested to represent a sort of buffer capacity of the human body against inflammatory situations where an excess of TNF is released into the circulation $(22,138)$. Moreover, by releasing the extra cellular part of the TNF receptor, the cells were temporary less sensitive to the harmful effects of TNF. Nevertheless, it was also suggested that STNFR could prolong the biologic effects of TNF by stabilization of the molecule and by forming a "slow release reservoir" (22). In line with the hypothesis that sTNFR can bind TNF, thereby preventing the toxic effects of TNF, experiments in animal models have shown that administration of sTNFR can protect mice from lethal effects of TNF and septic shock (91). In a baboon model, it was shown that sTNFR injection before administration of an $\mathrm{LD}_{100}$ of live E. Coli. resulted in diminished volume of resuscitation fluid required to maintain the animals in a stabile phase and a diminished fall in arterial blood pressure (164). Recently, soluble receptor constructs were developed, consisting out of the extracellular part of the TNF receptor coupled to a human Fc part. These constructs were shown to be even more effective in preventing mortality in sepsis models than the sTNFR itself, probably because of their increased affinity and avidity for $\operatorname{TNF}(21,167)$.

The latest data reveal that in patients with renal failure, the levels of soluble TNF receptors are increased, which implicates an important role for the kidney in regulation of circulating levels of TNF receptors (92). These observations necessitate monitoring 
of renal function in patients where diminished renal function is expected. Nevertheless, sTNFR measurements seem to provide a useful addition for monitoring inflammatory reactions.

\section{Cytokines}

\subsection{Cytokines in gastrointestinal diseases}

As already mentioned, the discovery of cytokines gave new impulses to research on the pathophysiology of GI diseases. It became clear that the inflammatory cytokines were involved in most GI disease. In Crohn's disease, there is evidence for a continuous IL-6 production, most likely a reflection of continuous stimulation of IL-6 producing cells (168). In childhood inflammatory bowel disease (IBD) there is evidence for a rise of TNF in the serum when the disease exacerbates (36). Moreover, it was suggested that TNF played a role in the growth failure which is observed in children with IBD (169). Monocytes of patients with IBD show increased production of inflammatory cytokines such as IL-1B, IL-6 and TNF $(37,38,170)$, while monocytes of patients with hepatitis produce increased amounts of TNF $(171,172)$ and isolated intestinal lamina propria mononuclear cells of IBD patients are clearly activated (173). It was demonstrated that TNF and PAF are present in the stool of patients with IBD, shigella dysenteriae infection and pouchitis, especially during exacerbation of the disease (39-42). Also expression of adhesion molecules (proteins present on the luminal surface of endothelial cells which can bind to circulating neutrophils), such as ELAM-1 (E-selectin) is increased during inflammatory episodes of IBD (174). In primary biliary cirrhosis and primary sclerosing cholangitis high circulating levels of ICAM-1 are present (175). Moreover, cytokine production by T-lymphocytes in the former group was reported to be diminished upon stimulation (176).

\subsection{Cytokines in obstructive jaundice}

There are also indications that cytokines could play a role in obstructive jaundice. Greve demonstrated in a rat model with experimental biliary obsuruction that in several animais circulating TNF was present (23). Although the data were difficult to interpret, probably due to the short halflife of TNF, they suggested that TNF and endotoxin might be involved in mortality after trauma in jaundiced rats.

As mentioned previously, obstructive jaundice is accompanied by the presence of endotoxemia. These endotoxins must be inactivated by Kupffer cells (177). During obstructive jaundice however, these cells are not functioning properly, resulting in overflow of endotoxins from the portal circulation into the systemic circulation (177. 179). These endotoxins in the systemic circulation might lead to the release of inflammatory cytokines. This putative production of cytokines in response to endotoxin might explain the malaise and some of the complications observed after surgery in obstructive 
jaundice, especially since there is growing evidence that overproduction of cytokines can be harmful to the host. In line with this last hypothesis, antibodies, receptor antagonists, soluble receptors or drugs affecting cytokine levels or production may offer a useful intervention method to deal with the sometimes exaggerated cytokine response in GI diseases such as biliary obstruction. Moreover, interference in the cascade of deranged cytokine release might elucidate some parts of the pathophysiology of GI diseases.

\section{Aim of the thesis}

The goal of this thesis is to investigate the putative involvement of cytokines (TNF, soluble TNF Receptors and IL-6) in experimental biliary obstruction in mice and in the complications frequently occurring during the disease. Parallel, in order to better understand the complex regulatory mechanisms of cytokines, we investigated the kinetics of circulating TNF and its soluble receptors in a murine model. 


\section{Chapter 2 \\ INTRODUCTION AND DISCUSSION \\ OF THE EXPERIMENTAL WORK}

In the first experimental study presented in Chapter 3, the presence of the cytokines IL-6 and TNF in the serum of jaundiced mice is investigated. Previous reports showed that endotoxins are present in the circulation of jaundiced patients and animals with experimental biliary obstruction $(27,28,43)$. As already discussed in the introduction, the presence of microbial products such as endotoxins in the circulation will lead to the release of inflammatory cytokines, IL-6 and TNF. These circulating inflammatory cytokines are investigated in jaundiced mice in an attempt to elucidate the complex pathophysiology underlying the complications observed in obstructive jaundice.

In order to assess a potential activated state of peritoneal macrophages of these jaundiced mice as a result of the inflammatory status, the spontaneous and induced production of IL-6 and TNF by peritoneal macrophages was evaluated.

The resuits of the study show that 3-4 hours after surgery a strong increase in serum IL-6 levels is observed in both sham operated mice and jaundiced mice. However, while IL-6 in the sham operated mice decreased in the days after the operation till levels around detection limits. IL-6 levels in biliary obstructed mice showed a second increase after 10-12 days. Moreover, TNF was present in the circulation of jaundiced mice, which was in contrast to sham operated mice where no TNF was detectable in the circulation.

The results of both the spontaneous and indiced cytokine production by the macrophages revealed that macrophages of jaundiced mice produced significantly more IL- 6 and TNF compared to sham operated mice.

Taken together, these data strongly suggest that biliary obstruction is accompanied by an inflammatory status as reflected by the serum cytokine levels and the activated state of the peritoneal macrophages. The observation that an altered inflammatory and immunological status is present in jaundiced mice is in line with previous reports describing endotoxins in the circulation of jaundiced patients and jaundiced animals, resulting in several immunological derangements $(28,43,178,179)$. These derangements include depressed immune function, reduced phagocytic capacity of Kupffer cells, and coagulation disorders.

Recent studies have shown that TNF can be harmful when present in excess in the circulation (eg after endotoxin injection or in meningococcal disease)(32,132). In line with these observations, administration of anti-TNF antibodies protected animals against a lethal endotoxin shock (132). Trauma in obstructive jaundice, a situation in 
which endotoxins and cytokines are present in the circulation, is also connected with a high mortality (23). Since intervention in the TNF regulation in animals with a lethal endotoxin shock had such impressive results, this prompted us to investigate whether similar intervention in jaundiced animals before a surgical trauma would also be beneficial.

In Chapter 4, a model is presented of a surgical trauma in jaundiced mice which is associated with a considerable mortality. The model was originally used by Zager et al. in septic animals (180). Later it was also used in jaundiced rats by Greve and it was considered a good model for surgical trauma in jaundiced animals (23). The trauma consisted of bilateral renal ischemia (RI) during 30 minutes.

The mortality observed after RI was accompanied by high TNF levels and a high mortality, an observation which was in line with the results reported by Greve et al. in jaundiced rats. TNF was blocked by administration of a monoclonal anti-TNF antibody (TN3) or pentoxifylline (a well known anti-TNF agent). Also lactulose syrup orally was used, a well known anti-endotoxin agent. Moreover, lactulose was earlier shown to reduce the LPS induced TNF production by monocytes and to reduce mortality after a trauma in jaundiced rats $(23,181)$. The results obtained after RI in jaundiced mice show that blocking TNF by TN3 or pentoxifylline administration significantly reduced TNF levels, but failed to reduce mortality. Lactulose however significantly reduced TNF levels and mortality. These data suggest that next to TNF other factors are involved, since blocking TNF alone was not sufficient to reduce mortality. Lactulose supposedly affected one of these additional factors. Since lactulose was present in the intestine and because the intestine is considered to be the motor of sepsis, one might speculate that the presence of lactulose in the intestine is of importance.

The fact that blocking TNF alone was not successful in obstructive jaundice could be the result of differences in TNF properties in obstructive jaundice compared to the situation where mice are injected with LPS, where anti-TNF treatment works well (132). After all, after an endotoxin injection TNF is present in the circulation for a short period of time, while during obstructive jaundice the presence of TNF is longer lasting.

Another reason which could play a role in the ineffectiveness of the anti-TNF treatment was the fact that just recently, it became evident that TNF was present in two forms $(135,136)$. A biologically active form could be present representing the "free" TNF molecule and an inactive form which was however immunologically detectable and consisted supposedly of TNF bound to TNF "binding proteins". Therefore, in Chapter 5 , both forms of TNF were studied in jaundiced mice using two different assays. Bioactive TNF was measured with a bioassay (WEHI-assay, a cell cytotoxicity assay), whereas immunologically detectable TNF was detected by ELISA. The data obtained revealed that TNF present in obstructive jaundice was biologically inactive and that it probably consisted of TNF and TNF binding proteins. 
The fact that TNF was biologically inactive could very well play a role in the ineffectivity of anti-TNF treatment. Moreover, these results are in contrast to the LPS shock model where pretreatment with a monoclonal anti-TNF antibody was shown to be protective against a lethal endotoxin shock. This implicates that the pathophysiology in both models is different.

Recently, as mentioned in the introduction, it was discovered that two soluble TNF receptors (sTNFR-P55 and STNFR-P75) were present in the circulation of healthy human volunteers $(139,142,160)$. These soluble receptors were suggested to play an important role in inactivation of TNF. Engelmann et al. and Porteu et al. showed that these receptors most likely represented the proteolytically cleaved extracellular part of the membrane bound TNF receptors $(138,139,162)$. Moreover, the group of Wallach et al. showed that the TNF binding proteins discovered by Lantz et al., Peetre et al. and Dayer et al. were identical to these extra cellular parts of the TNF receptors, the so called soluble TNF receptors (sTNFR) $(140,160,161,182)$. These soluble TNF receptors were thought to be inactivators of TNF. However, they could also function as slow release reservoirs, thereby prolonging the local effects of TNF, which has a short half life (22).

Because TNF in biliary obstructed mice was inactive and since TNF binding proteins or sTNFR were supposed to play a role in this inactivation, this prompted us to further unravel sTNFR regulation and function in jaundiced mice. Therefore, a new ELISA was developed to measure s'TNFR (sTNFR-P55 and sTNFR-P75) in mice using highly specific polyclonal antibodies against both soluble murine TNF receptors. Measurement of the sTNFR in the circulation of jaundiced mice showed that levels of both soluble receptors are significantly increased. This fact could be responsible for the observation that serum TNF in jaundiced mice is mostly circulating in inactive form. Moreover, increased sTNFR levels seem be better markers reflecting the inflammatory response in these mice than TNF.

Because in the previous Chapter lactulose was shown to be protective when given to jaundiced mice before RI by a mechanism unknown and because sTNFR were suggested to be very sensitive inflammatory markers, measurement of these sTNFR could be of value to further elucidate the mortality after RI in obstructive jaundice. Therefore, sTNFR levels were studied together with TNF levels after RI in jaundiced mice. Moreover, the effect of TN3, pentoxifylline and lactulose was tested on the outcome after surgery and on cytokine levels. The results reveal that both sTNFR are increased after RI. Moreover, sTNFR levels in contrast to circulating TNF levels show a good correlation with mortality. Of the agents tested, only lactulose reduced mortality as was also observed in the experiments described in Chapter 4. In addition, lactulose significantly reduced sTNFR-P75 levels. The reduced sTNFR-P75 levels might very well be an indication for a reduction of the inflammatory situation in these mice, which could very well play a role in the reduction of the mortality after lactulose pretreatment. 
So far, the results showed that IL-6, TNF and sTNFR were present in the circulation of jaundiced mice. The data obtained showed that TNF in these mice was inactive and suggest that a constant production, inactivation and clearance was present in these mice.

Since the mechanism of TNF regulation and clearance was not completely clear, this prompted us to investigate clearance of TNF in a murine model. Recent reports suggested that TNF clearance was largely regulated by the kidney (183-185). In Chapter 6, data on the role of the kidney in TNF clearance are presented.

Analysis of the kinetics of TNF after simple bilateral nephrectomy showed that circulating TNF levels increase, which suggests that the kidney is the most important organ in TNF clearance. However, this TNF was biologically inactive.

As already mentioned, endotoxin (LPS) present in jaundiced mice, is a well known inducer of TNF. To further unravel the role of the kidney in TNF clearance, TNF levels were also studied in a septic mode! after nephrectomy.

The data show that levels of biologically active TNF are similar in both groups of mice after LPS. Levels of immunologically detectable TNF are however significantly higher in BN mice compared to the control mice. These data suggest that inactivation of TNF is equally effective in both groups. Clearance of the immunologically detectable TNF complexes however, seems strongly impaired in $\mathrm{BN}$ mice.

The differential affinity of human and murine TNF for murine sTNFR-P55 and murine sTNFR-P75 was used to study which receptor was involved in TNF metabolism. In this study, murine TNF was measured with the WEHI-bioassay (bioactive TNF) and with a murine TNF specific ELISA recognizing immunologically detectable TNF. Bioactive human TNF was measured with the WEHI bio-assay and an ELISA which was reported to recognize only free bioactive TNF (135). Moreover, immunologically detectable human TNF was detected with the MEDGENIX ELISA, which was shown to detect the total amount of human TNF (136). The data reveal that human TNF in contrast to murine TNF is not inactivated in mice in the circulation, data that strongly suggest that sTNFR-P75 rather than sTNFR-P55 is involved in inactivation of TNF. Furthermore, these data show that in mice sTNFR-P75 is the most important receptor for inactivation and clearance of TNF. This was not surprising since the serum levels of sTIFR-P75 were approximately 100 times higher than sTNFR-P55 levels in mice. Moreover, these data also indicate that in experiments where human TNF in mice is used, one has to realize that only effects of triggering the TNFR-P55 are investigated. The discrepancy in sTNFR serum levels in mice is in contrast to the situation in man and monkeys where sTNFR-P55 and sTNFR-P75 levels are in the same range $(20,164,165)$. The exact role of the discrepancy between these species is not yet known.

To further strengthen our hypothesis that sTNFR-P75 was responsible for inactivation of TNF, additional radiolabellings studies were performed. After injection of ${ }^{125} \mathrm{I}$ labelled TNF, it was studied which receptor bound the TNF molecule using immunoprecipitation techniques. Moreover, it was investigated whether the TNF molecule was 
intact after binding to one of the receptors. The results showed that STNFR-P75 was the predominant receptor which bound TNF. Moreover, binding of the STNFR-P75 to the TNF molecule did not result in breakdown of the TNF molecule, since the molecular weight of TNF after binding remained identical.

These data further strengthen the role of sTNFR-P75 in the clearance and inactivation of TNF. Moreover, the role of the kidney in this process was elucidated. Nevertheless, despite the indications that STNFR play a role in inactivation and clearance of TNF by the kidneys, regulation of sTNFR clearance itself is not yet clear. Therefore, in Chapter 7 , the role of the kidney in clearance of sTNFR was studied.

First, the effect of bilateral nephrectomy (BN) on serum levels of both receptors was studied. The results showed that after nephrectomy a rapid increase in serum levels of both sTNFR's was observed. After approximately 4 hours, a plateau level was reached, which suggested that other organs take over the clearance, although this taking over was associated with a considerable delay. Moreover, this new equilibrium was reached at the cost of a higher serum level of the receptors.

In vivo, LPS was shown to lead to a rapid increase in TNF and sTNFR levels in the circulation. Because the kidney was suggested to be an important organ in STNFR clearance, the effect of rapid release of sTNFR induced by LPS was studied in this model. Therefore, BN mice were injected with LPS. After LPS injection and nephrectomy, an strong increase in STNFR was observed. The kinetics were identical as after simple nephrectomy, only the absolute sTNFR levels were higher. These data suggested that even at higher serum sTNFR levels, other organs were still capable of installing a new equilibrium. This equilibrium is reached however, at the cost of a much higher serum level of sTNFR compared to the situation without LPS. To further unravel the clearance of soluble receptors, one receptor (sTNFR-P75) was purified and ${ }^{125}$ I labelled. The sTNFR-P75 was chosen, since the data from Chapter 6 revealed that this was the most important receptor for TNF inactivation and clearance in mice. After injection of the labelled protein, blood samples, tissue samples and urine were taken. These experiments offered the opportunity to study the half life of the receptor on the one hand and the tissue distribution of the receptor on the other hand. In that way, additional information could be acquired about the clearance of the sTNFR. The results showed that the highest radioactivity signals were observed in the urine and kidneys, followed by liver, spleen and lungs. These data underlined the role of the kidney in clearance of sTNFR but in addition supported the hypothesis that other organs such as the liver, spleen and lungs were also involved.

In order to further investigate the role of the kidneys, similar experiments were performed in bilaterally nephrectomized mice. The data show that BN reduced the parametric clearance rate of the receptor with approximately $50 \%$. Uptake of radioactivity by liver, spleen and lungs was clearly increased in BN mice compared to sham operated mice, supporting the hypothesis that other organs take over the clearance in absence of the kidneys. 
The data obtained from the experiments described in Chapter 6 and 7 show that the kidney is of major importance for proper regulation of TNF and STNFR levels.

Therefore, in diseases in which renal function is affected, interpretation of TNF and sTNFR levels is extremely difficult. Increased levels in these diseases are partially the result of diminished renal function and partially the result of the inflammatory reaction. Moreover, the data from the previous Chapters suggest that TNF is a cytokine which is meant to function locally and which is extremely harmful when it is present in excessive quantities in the systemic circulation. Therefore, the body possesses protective mechanisms such as the release of TNFR from the cell membrane, which has a dual effect. On the one hand, the cell is temporarily insensitive to TNF, on the other hand the release provides the body with high amounts of inactivators (sTNFR) for the inactivation of the TNF molecule.

If this hypothesis is correct, the body must be able to release enormous amounts of sTNFR in a very short period of time to bind TNF thereby preventing systemic effects of the TNF molecule, such as hypotension and shock. In vitro data showed that TNF receptors can be released from the cell membrane by several agents such as $\mathrm{N}$-formylmethionyl-leucyl-phenylalanine (FMLP), C5a, TNF and LPS $(138,162)$. Moreover, the reports of Spinas and van Zee showed that LPS could lead to increased levels of soluble TNF receptors in the circulation $(20,164)$.

To further investigate this hypothesis, the mechanism of soluble TNFR release was studied in two different in vivo models, an endotoxin model and a model of T-cellular activation. In Chapter 8 experiments are presented aimed to investigate the mechanism and kinetics of LPS induced sTNFR release in vivo. In those studies, the role of several potent cytokines, TNF, IL-1, Leukemia Inhibiting Factor (LIF), and IFN- $\gamma$ in the release of sTNFR was investigated. These cytokines were tested because recent reports suggested that they were in one or another way of importance in LPS induced mortality. The results show that although these cytokines are involved in LPS induced sTNFR release, none of them regulates sTNFR release exclusively.

Previous reports showed that during diseases where T-cell activation is present such as rheumatoid arthritis high levels of circulating TNF are observed (186). Moreover, injection with an anti-CD3 in mice results in a massive cytokine release (TNF, IFN- $\gamma$, IL-2, IL-6, IL-3, IL-10) together with a reversible systemic clinical reaction (chills, headache, pyrexia, vomiting, diarrhea, and tachycardia) $(187,188)$.

In Chapter 9, it was studied whether the systemic TNF release by in vivo $\mathrm{T}$-cell activation using an anti-CD3 $\mathrm{mAb}$ was accompanied by the release of soluble TNF receptors. Moreover, because TNF is supposed to play an important role in the anti$\mathrm{CD} 3$ induced syndrome, the effect of an anti-TNF mAb and pentoxifylline (a known TNF reducing agent) on anti-CD3 induced sTNFR release was studied. Since anti-CD3 not only induces the release of TNF but also the release of IFN- $\gamma$ and because IFN- $\gamma$ is supposed to play an important role in this mechanism, the effect of pretreatment with a $\mathrm{mAb}$ against IFN- $\gamma$ was studied. The results show that anti-CD3 injection induced the release of sTNFR in the circulation. The regulation was however clearly different 
from the LPS induced sTNFR release. In addition, reduction of TNF and IFN- $\gamma$ affected significantly sTNFR levels. Despite the changes in STNFR levels, TNF and IFN- $\gamma$ are not the sole mediators regulating the sTNFR release. Other, still unknown factors are bound to be involved.

Because steroids reduce TNF levels and because they are used in clinical situations in man to attenuate the side effects consecutive to the first injections of OKT3 $(189,190)$, the effect of pretreatment of the anti-CD3 injected mice with methylprednisolone (mPDS) was studied. The results showed that steroids reduced TNF levels without significant reduction of sTNFR levels. One might hypothesize that this represented a reduced inflammatory status together with still available buffer capacity by sTNFR levels.

In conclusion, these data show that in vivo LPS and anti-CD3 lead to a rapid increase in sTNFR levels, which fit with the hypothesis that these receptors are important factors for inactivation of circulating TNF.

The data from the previous investigations in mice reveal that during inflammation (a.o. in obstructive jaundice) cytokines are present. In addition, several reports showed that sepsis was accompanied by the release of circulating cytokines such as TNF, IL-6, and sTNFR $(20,54,164)$. The data from the previous Chapters suggested that TNF was meant to function locally and that it became harmful when present systemically. In addition, the kidney was shown to be an important organ for clearance of TNF and sTNFR. The importance of a good renal function for clearance of both TNF and sTNFR is stressed in Chapter 6 and 7. In order to prevent these systemic effects, the body possessed defending mechanisms such as sTNFR to inactivate TNF. In Chapter 8 and 9 it was shown that in keeping with this hypothesis, induction of TNF release by LPS or T-cellular activation was associated with a rapid increase in STNFR levels.

In order to study cytokine levels and renal function in clinical situations, the study described in Chapter 10 was performed. In that Chapier, the presence of the cytokines IL-6, TNF and sTNFR in the circulation of septic patients with a positive blood culture was studied. Furthermore, the renal function in these patients was studied.

The data reveal that in line with literature data, IL-6 leveis in contrast to TNF levels show a good correlation with monality. Interestingly, sTNFR levels correlated with mortality as well as renal function, while TNF showed hardly any correlation with mortality. The results suggest that the increased sTNFR levels are partially the result of the reduced renal function and partially of the inflammatory processes in these patients, which makes interpretation of these levels in these patients difficult. Nevertheless, in diseases where renal function is unaffected, sTNFR levels probably reflect very accurate inflammation and are therefore of value. Moreover, since sTNFR levels are increased over a longer period of time compared with TNF levels, sTNFR. levels provide more information on the inflammatory status. 
Future research will further elucidate the interpretation and usefulness of cytokine levels in inflammatory diseases and eventually, the pathophysiology underlying the inflammatory derangements will be further clarified. 


\section{REFERENCES TO CHAPTER 1 AND 2}

1. Baue, A.E. The horror autotoxicus and multiple-organ failure. Arch Surg. 1992;127:1451. 1462.

2. Ayala, A., M.M. Perrin, M.A. Wagner, I.H. Chaudry. Enhanced susceptibility to sepsis after simple hemorrhage. Arch. Surg. 1990;125:70-75.

3. Rock, C.S., S.M. Coyle, C.V. Keogh, D.D. Lazarus, A.S. Hawes, M. Leskiw, L.L. Moldawer, T.P. Stein, S.F. Lowry. Influence of hypercortisolemia on the acute-phase protein reponse to endotoxin in humans. Surgery 1992;112:467-474.

4. Dinarello, C.A. Interleukin-1 and the pathogenesis of the acute-phase response, New Eng. $J$. Med. 1984;311:1413-1418.

5. Biochemistry of inflammation (Immunology and medicine series). Volume 18, chapter 13. Edited by J.T. Whicher and S.W. Evans. Kluwer Academic publishers 1992.

6. Balkwell, F.R., F. Burke. The cytokine network. Immunol. Today 1989;10:299-304.

7. McConnen, M. Immunex's soluble receptors proving their anti-inflammatory point in the clinic. Biotechnology News 1993;13:1.

8. Howard, M., T. Muchamuel, S. Andrade, S. Menon. Interleukin-10 protects mice from iethal endotoxemia. J. Exp. Med. 1993;177:1205-1208.

9. Paul, S.R., F. Bennett, J.A. Calvetti, K. Kelleher, C.R. Wood, R.M. O'Hara, Jr., A.C. Leary, B. Sibley, S.C. Clark, D.A. Williams, Y.C. Yang. Molecular cloning of a cDNA encoding Interleukin 11, a stromal cell-derived lymphopoetic and hematopoetic cytokine. Proc. Nail. Acad. Sci. USA 1990;87:7512-7516.

10. Schoenhaut, D.S., A.O. Chua, A.G. Wolitzky, P.M. Quinn, C.M. Dwyer, W. McComas, P.C. Familletti, M.K. Gately, U. Gubler. Cloning and expression of murine IL-12. J. Immunol. 1992;148:3433-3440.

11. Minty, A., P. Chalon, J.-M. Derocg, X. Dumont, J.-C. Guillemot, M. Kaghad, C. Labii, P. Leplatois, P. Liauzun. B. Miloux. C. Minty, P. Cassellas, G. Loison, J. Lupker, D. Shire, P. Ferrara, D. Caput. Interleukin-13 is a new human lymphokine regulating inflammatory and immune responses. Nature 1993;362:248-250.

12. Howard, M., A. O'Garra. Biological properties of Interleukin-10. Immunol. Today 1992:13:198-200.

13. Molloy, R.G., J.A. Mannick, M.L. Rodrick. Cytokines, sepsis and immunomodulation. Br. J. Surg. 1993;80:289-297.

14. Welbourn, C.R.B., Y. Young. Endotoxin, septic shock and acute lung injury: neutrophils, macrophages and inflammatory mediators. Br. J. Surg. 1993:79:998-1003.

15. Alexander, H.R., G.M. Doherty, C.M. Buresh, D.J. Venzon, J.A. Norton. A recombinant human receptor antagonist to interleukin-1 improves survival after lethal endotoxemia in mice. J. Exp. Med. 1991;173:1029.1032.

16. Alexander, H.R., G.M. Doherty, D.J. Venzon, M.J. Merino, D.L. Fraker, J.A. Norton. Recombinant Interleukin-1 receptor antagonist (IL-1 ra): effective therapy against gram-negative sepsis in rats. Surgery 1992;112:188-194.

17. Stames, H.F., Jr., M.K. Pearce, A. Tewari, J.H. Yim, J.-C. Zou, J.S. Abrahams. Anti-IL-6 monoclonal antibodies protect against lethal Escherichia coli infection and lethal Tumoir Necrosis Factor- $\alpha$ challenge in mice. J. Immunol. 1990:145:4185-4191. 
18. Heremans, H., C. Dillen, W. Put, Jo van Damme, A. Billiau. Protective effect of antiInterleukin (IL)-6 antibody against endotoxin, associated with paradoxically increased IL-6 levels. Eur. J. Immunol. 1992:22:2395-2401.

19. Silva, A.T., K.F. Bayston, J. Cohen. Prophylactic and therapeutic effects of a monoclonal antibody to Tumor Necrosis Factor- $\alpha$ in experimental gram-negative shock. J. Inf. Dis. 1990;162:421-427.

20. Spinas, G.A., U. Keller, M. Brockhaus. Release of soluble receptors for Tumor Necrosis Factor (TNF) in relation to circulating TNF during experimental endotoxemia. J. Clin. Invest. 1992:90:533-536.

21. Lesslauer, W., H. Tabuchi, R. Gentz, M. Brockhaus, E.J. Schlaegger, G. Grau, P.F. Piguet, P. Pontaire, P. Vassali, H. Loetscher. Recombinant soluble Tumor Necrosis Factor receptor proteins protect mice from lipopolysaccharide-induced lethality. Eur. J. Immunol. 1991;21: 2883-2886.

22. Aderka, D., H. Engelmann, Y. Maor, C. Brakebush, D. Wallach. Stabilization of the bioactivity of Tumor Necrosis Factor by its soluble receptors. J. Exp. Med. 1992;175:323-329.

23. Greve, J.W., J.G. Maessen, T. Tiebosch, W.A. Buurman, D.J. Gouma. Prevention of postoperative complications in jaundiced rats. Ann. Surg. 1990;212:221-227.

24. Blamey, S.L., K.C.H. Fearon, W.H. Gilmour, D.H. Osborne, D.C. Carter. Prediction of risk in biliary surgery. Br. J. Surg. 1983;70:535-538.

25. Pitt, H.A., J.L. Cameron, R.G. Postier, T.R. Gadacz. Factors affecting mortality in biliary tract surgery. Am. J. Surg. 1981;141:66-72.

26. Clements, W.D.B., T. Diamond, D.C. McCrory, B.J. Rowlands. Biliary drainage in obstructive jaundice: experimental and clinical aspects. Br. J. Surg. 1993;80:834-842.

27. Diamond, T., S. Dolan, R.L.E. Thompson, B.J. Rowlands. Development and reversal of endotoxemia and endotoxin-related death in obstructive jaundice. Br. J. Surg. 1990;108:370375 .

28. Hunt, D.R., M.E.M. Allison, C.R.M. Prentice, L.H. Blumgart. Endotoxemia, disturbance of coagulation, and obstructive jaundice. Am. J. Surg. 1982;144:325-329.

29. Shands, J., Jr., P.W. Chun. The dispersion of gram-negative lipopolysaccharide by deoxycholate. J. Biol. Chem. 1980:255:1221-1226.

30. Tarminia, D.F., K.C. Milner, E. Ribi, J. Rudbach. Reaction of endotoxin and surfactants. II. immunologic properties of endotoxins treated with sodium deoxycholate. J. Immunol. $1968: 100: 444-450$.

31. Ribi, E., R.L. Anacker, R. Brown, W.T, Haskins, B. Malmgren, K.C. Milner, J.A. Rudbach. Reaction of endotoxin and surfactants. I. Physical and biological properties of endotoxin treated with sodium deoxycholate. J. Bacteriol, 1966;92:1493-1509.

32. Waage, A., A. Halstensen, T. Espevik. Association between Tumour Necrosis Factor in serum and fatal outcome in patients with meningococcal disease. Lancet 1987:355-357.

33. Kampschmidt, R.F., L.A. Pulliam. Effect of human monocyte pyrogen on plasma iron, plasma zinc, and blood neutrophils in rabbits and rats. Proc. Soc. Exp. Biol. Med. 1978:158:32-35.

34. Myers, M.A., A. Fleck, B. Sampson, C.M. Colley, J. Bent, G. Hall. Early plasma protein and mineral changes after surgery: a two stage procedure. J. Clin. Path. 1984;37:862-866.

35. Casals-Stenzel, J. Protective effect of WEB 2086, a novel antagonist of platelet activating factor, in endotoxic shock. Eur. J. of Pharmacol. 1987:135:117-122.

36. Murch, S.H., V.A. Lamkin, M.O. Savage, J.A. Walker-Smith, T.T. MacDonald. Serum concentrations of Tumour Necrosis Factor $\alpha$ in childhood chronic inflammatory bowel disease. Gut 1991;32:913-917.

37. Mahida, Y.R., E. Scott, L. Kurlak, A. Gallagher, C.J. Hawkey, Interleukin 1B, Tumour 
Necrosis Factor $\alpha$ and Interleukin- 6 synthesis by circulating mononuclear cells isolated from patients with active Ulcerative Colitis and Crohn's disease. Eur. J. Gastroenterolgy and Hepatol. 1992:4:501-507.

38. Andus, T., V. Gross, I. Casar, D. Krumm, J. Hosp, M. David, J. Schölmerich. Activation of monocytes during inflammatory bowel disease. Pathobiology 1991:59:166-170.

39. De Silva, D.G.H, L.N. Mendis, N. Sheron, G.J.M. Alexander, D.C.A. Candy, H. Chart, B. Rowe. TNF $\alpha$ in stool as marker of intestinal inflammation. Lancet 1992;340:372 (letter).

40. Braegger, C.P., S. Nicholls, S.H. Murch, S. Stephens, T.T. Macdonald. Tumour Necrosis Factor alpha in stool as a marker of intestinal inflammation. Lancet;339:89-91.

41. Lanfranchi, G.A., A. Tragnone. Serum and faecal Tumour Necrosis Factor- $\alpha$ as marker of intestinal inflammation. Lancet 1992;339:1053 (letter).

42. Chaussade, S., Y. Denizot, J.F. Colombel, J. Benvensite, D. Couturier. Paf-acether in stool as marker of intestinal inflammation. Lancet 1992;339:739 (letter).

43. Greve, J.W., D.J. Gouma, P.B. Soeters, W.A. Buurman. Suppression of cellular immunity in obstructive jaundice is caused by endotoxins: a study with germ-free rats. Gastroenterology 1990:98:478-485.

44. Pinto, M., A. Kaplun. Immune status in mice with experimental biliary obstruction. Clin. Immunol. Immunopath. 1980;16:396-405.

45. Roughneen, P.T., A.D. Kulkarni, D.J. Gouma, W.C. Fanslow, B.J. Rowlands. Suppression of host versus graft response in experimental biuliary obstruction. Transplantation 1986;42:687689.

46. Roughneen, P.T., D.J. Gouma, A.D. Kulkami, W.F. Fanslow, B.J. Rowlands. Impaired specific cell-mediated immunity in experimental biliary obstruction and its reversibility by internal biliary drainage. J. Surg. Res. 1986:41:113-125.

47. Holman, J.M., L.F. Rikkers. Biliary obstruction and host defense failure. J. Surg. Res. 1982:32:208-213.

48. Drivas, G., O. James, N. Wardle. Stydy of reticuloendothelial phagocytic capacity in patients with cholesthasis. Br. Med. J. 1976;1:1568-1569.

49. Jacob, A.I., P.K. Goldberg, N. Bloom, G.A. Degenshein, P.J. Kozinn. Endotoxin and bacteria in portal blood. Gastroenterology 1977;72:1268-1270.

50. Nolan, J.P. Intestinal endotoxins as mediators of hepatic injury, an idea whose time has come again. Hepatology 1989:10:887-891.

51. Cahill, C.J., J.A. Pain, M.E. Bailey, Bile salts, endotoxin and renal function in obstructive jaundice. Surg. Gynecol. Obstet. 1987:165:519-522.

52. Ingoldby, C.J.H. The value of polymixin B in endotoxemia due to experimental obstructive jaundice and mesenteric ischaemia. Br. J. Surg. 1980;67:565-567.

53. Bailey, M.E. Endotoxin, bile salts and renal function in obstructive jaundice. Br. I. Surg. 1976;63:774-778.

54. Spinas, G.A., D. Bloesch, U. Keller, W. Zimmerli, S Cammisuli. Pretreatment with ibuprofen augments circulating Tumor Necrosis Factor- $\alpha$, Interleukin- 6 , and elastase during acute. endotoxemia. J. Inf. Dis. 1991:163:89-95.

55. Nishimoto, N., K. Yoshizaki, H. Tagoh, M. Monden, S. Kishimoto, T. Hirano, T. Kishimoto. Elevation of serum Interleukin-6 prior to acute phase proteins on the inflammation by surgical operation. Clin. Immunol. Immunopath. 1989;50:399-40I.

56. Ohzato, H., K. Yoshizaki, N. Nishimoto, A. Ogata, H. Tagoh, M. Monden, M. Gotoh, T. Kishimoto, T. Mori. Interleukin-6 as a new indicator of inflammatory status: detection of serum levels of Interleukin-6 and C-reactive protein after surgery. Surgery, 1992;111:201-209.

57. Okusawa, S., J.A. Gelfand, T. Ikejima, R.J. Conolly, C.A. Dinarello. Interleukin-1 induces a shock-like state in rabbits. J. Clin. Invest. 1988;81:1162-1172. 
58. Vilcek, J., J. Le. In: the cytokine handbook, Chapter 1:1-17. Edited by Angus Thompson. London 1992 Academic press limited.

59. Dumonde, D.C., R.A. Wolstencroft, G.S. Panayi, M. Matthew, J. Morley, W.T. Howson. "Lymphokines": Non-antibody mediators of cellular immunity generated by lymphocyte activation. Nature 1969;224:38-42.

60. Aarden, L.A., T.K. Brunner, J.-C. Cerottini, J.-M. Dayer, A.L de Weck, C.A. Dinarello, G.Di Sabato, J.J. Farrar, I. Gery, S. Gillis, R.E. Handschumacher, C.S. Henney, M.K. Hoffmann, W.J. Koopman, S.M. Krane, L.B. Lachman, L. Lefkowits. Revised nomenclature for antigennonspecific T cell proliferation and helper factors. J. Immunol. 1979;123:2928-2929.

61. Carswell, E.A., L.J. Old, S. Green, N. Fiore, B. Williamson. An endotoxin-induced serum factor that causes necrosis of tumors. Proc. Natl. Acad. Sci. USA 1975;72:3666-3670.

62. Gery, I., R.K. Gershon, B.M. Waksman. Potentiation of cultured mouse thymocyte responses by factors released by peripheral leukocytes. J. Immunol. 1971;107:1778-1780.

63. Dinarello. C.A. Interleukin-1. In: the cytokine handbook, Chapter 3:47-82. Edited by Angus Thompson. London 1992 Academic press limited.

64. Isaacs, A., J. Lindenmann. Virus interference. I. The interferon. Proc. R. Soc. (London), Ser. B. 1957:147:258-267.

65. Wheelock, E.F. Interferon-like virus-inhibitor induced in human leukocytes by phytohemagglutinin. Science 1965:149:310-311.

66. de Maeyer, E., J. de Maeyer-Guignard. Interferons. In: the cytokine handbook, Chapter 11:215-239. Edited by Angus Thompson. London 1992 Academic press limited.

67. Nicola, N.A. In: Colony Stimulating Factors; Cell and Molecular Biology (eds T.M. Dexter. J.M. Garland and N.G. Testa), Marcel Dekker, Inc, New York, pp. 77-I09.

68. De Larco, J.E., G.J. Todaro. Growth factors from murine sarcoma virus-transformed cells. Proc. Natl. Acad. Sci. USA 1978;75:4001-4005.

69. Border, W.A., E. Ruslahti. Transforming Growth Factor- $B$ in disease: the dark side of tissue repair. J. Clin. Invest. 1992;90:1-7.

70. Wahl, S., N. McCarthy-Francis, S.E. Mergenhagen. Inflammatory and immunomodulatory roles of TGF-B. Immunol, Today 1989;10:258-261.

71. Wahl, S. Transforming Growth Factor Beta (TGF-B) in inflammation: a cause and a cure. $J$. Clin. Immunol, 1992:12:61-74.

72. Zhou, D., A. Munster, R.A. Winchurch. Pathologic concentrations of Interleukin-6 inhibit Tcell responses via induction of activation of TGF-B. FASEB J. 1991;5:2582-2585.

73. Ayala. A., J.B. Knotis, W. Ertel, M.M. Perrin, M.H. Morrison. I. Shaudry. Role of Interleukin6 and Transforming Growth Factor- $B$ in the induction of depressed splenocyte response following sepsis. Arch. Surg. 1993;128:89-95.

74. Ayala, A., D.R. Meldrum, M.M. Perrin, I.H. Chaudry. The release of transforming growth factor- $B$ following haemorrhage: its role as a mediator of host immunosuppression. Immunology 1993;79:479-484.

75. Nikol, S., J.M. Isner, G. Pickering. M. Kearney, G. Leclerc, L. Weir. Expression of Transforming Growth Factor-BI is increased in human vascular restenosis lesions. J. Clin. Invest. 1992;90:1582-1592.

76. Shah. M., D.M. Foreman, M.W.J. Ferguson. Control of scarring in adult wounds by neutralising antibody to Transforming Growth Factor B. Lancet 1992:339:213-214.

77. Williams, R.S., A.M. Rossi, N. Chegini, G. Schultz. Effect of Transforming Growth Factor B. on postoperative adhesion formation and intact peritoneum. J. Surg. Res. 1992;52:65-70.

78. Cohen, S., P.E. Bigazzi, T. Yoshida. Similarities of T-cell function in cell-mediated immunity and antibody production. Cell. Immunol. 1974;12:150-159. 
79. Sehgal, P.B. Interleukin-6: a regulator of plasma protein gene expression in hepatic and nonhepatic tissues. Mol. Biol. Med. 1990;7:117-130.

80. Wong, G.C., S.C. Clark. Multiple actions of Interleukin-6 within a cytokine network. Immunol. Today 1988;9:137-139.

81. van Snick J., J.-C. Renauld, R.J. Simpson, C. Uyttenhove, A. Vink. Mouse IL-6: a hybridoma growth factor with multiple effects on normal B and T cells. Ann. N. Y. Acad. Sci. 1989;557: 206-214.

82. Hirano, T. Interleukin-6. In: the cytokine handbook, Chapter 8:169-190. Edited by Angus Thompson. London 1992 Academic press limited.

83. van Snick, J. Interleukin-6: an overview. Ann. Rev. Immunol. 1990,8:253-278.

84. Andus, T., T. Geiger, T. Hirano, H. Northoff, U. Ganter, J. Bauer, T. Kishimoto, P.C. Heinrich. Recombinant human B cell stimulatory factor 2 (BSF-2/IFN-B2) regulates Bfibrinogen and albumin mRNA levels in Fao-cells. FEBS Lett. 1987;221:18-22.

85. Brach, M.A., F. Herrmann. Interleukin-6: presence and future. Int. J. Lab. Res. 1992;22:143. 151.

86. Brakenhoff, J.P.J., M. Hart, L.A. Aarden. Analysis of human IL-6 mutants expressed in Escherichia coli. Biologic activities are not affected by deletion of amino acids 1-28. J. Immunol. 1989;143:1175-1182.

87. Yamasaki, K., T. Taga, Y. Hirata, H. Yawata, Y. Kawanishi, B. Seed, T. Taniguchi, T. Hirano, T. Kishimoto. Cloning and expression of the human Interleukin-6 (BSF-2/IFN B2) receptor. Science 1988;241:825-828.

88. Coulie, P.G., M. Stevens, J. van Snick. High- and low-affinity receptors for murine Interleukin-6. Distinct distribution on B and T cells. Eur. J. Immunol. 1989;19:2107-2114.

89. Gearing, D.P., M.R. Comeau, D.J. Friend, S.D. Gimpel, C.J. Thut, J. McGourty, K.K. Brasher, J.A. King, S. Gillis, B. Mosley, S.F. Ziegler, D. Cosman. The Il-6 signal transducer, gp 130: an oncostatin M receptor and affinity converter for the LIF receptor. Science 1992; 255:1434. 1437.

90. Fiers, W. Tumor Necrosis Factor, characterization at the molecular, cellular and in vivo level. FEBS Lett. 1991;285:199-212.

91. Bertini, R., R. Delgado, R. Faggioni, M. Gascon, A. Ythier, P. Ghezzi. Urinary TNF-binding protein (TNF soluble receptor) protects mice against the lethal effect of TNF and endotoxic shock. Eur. Cytokine Netw. 1993;4:39-42.

92. Brockhaus, M., Y. Bar-Khayim, S. Gurwicz, A. Frensdorff, N. Haran. Plasma Tumor Necrosis Factor soluble receptors in chronic renal failure. Kidney Int. 1992;42:663-667.

93. Olsson, I., M. L̇antz, E. Nilsson, C. Peetre, H. Thyssell, A. Grubb, G. Adolf. Isolation and characterization of a Tumor Necrosis Factor binding protein from urine. Eur. j. Haematol. $1989 ; 42: 270-275$.

94. Seckinger, P., K. Williamson, J.-F. Balavoine, B. Mach, G. Mazzei, A. Shaw, J.-M. Dayer. A urine inhibitor of Interleukin $I$ activity affects both Interleukin $I \alpha$ and IB but not Tumor Necrosis Factor $\alpha$. J. Immunol. 1987;139:1541-1545.

95. Seckinger, P., J.W. Lowenthal, K. Williamson, J.-M. Dayer, H.R. MacDonald. A urine inhibitor of Interleukin 1 activity that blocks ligand binding. J. Immunol. 1987;139:1546-1549.

96. Novick, D., H. Engelmann, D. Wallach. Purification of soluble cytokine receptors from normal human urine by ligand-affinity and immunoaffinity chromatography. J. Chromatogr. 1990;510:331-337.

97. Sehgal, P.B., D.C. Helfgott, U. Santhanam, S.B. Tatter, R.H. Clarick, J, Ghrayeb, L.T. May. Regulation of the acute phase and immune responses in viral disease. J. Exp. Med. 1988;167: $1951-1956$. 
98. Asano, S., A. Okano, K. Ozawa, t. Nakahata, T. Ishibashi, K. Koike, H. Kimura, Y. Tanioka, A. Shibuya, T. Hirano, T. Kishimoto, F. Takaku, Y. Akiyama. In vivo effects of recombinant Interleukin-6 in primates: stimulated production of platelets. Blood 1990;75:1602-1605.

99. Ishibashi, T., H. Kimura, Y. Shikama, T. Uchida, S. Kariyone, T. Hirano, T. Kishimoto, F. Takatsuki, Y. Akiyama. Interleukin-6 is a potent thrombopoietic factor in vivo in mice. Blood $1989 ; 74: 1241-1244$.

100. Castell, J.V., M.J. Gómez-Lechón, M. David, T. Hirano, T. Kishimoto, P.C. Heinrich. Recombinant human Interleukin-6 (IL-6/BSF-2/HSF) regulates the synthesis of acute phase proteins in human hepatocytes. FEBS Lett. 1988;232:347-350.

101. Ayala, A., P. Wang. Z.F. Ba, M.M. Perrin, W. Ertel, L.H. Chaudry. Differential alterations in plasma. IL-6i and TNF levels after trauma and hemorrhage. Am. J. Physiol. 1991:260:RI67. RI7I.

102. Kelly, N.M., A.S. Cross. Interleukin-6 is a better marker of lethality than Tumor Necrosis Factor in endotoxin treated mice. FEMS Mirobiol. Immunol. 1992;89:317-322.

103. Hack, C.E., E.R. De Groot, R.J.F. Felt-Bersma, J.H. Nuijens, R.J.M. Strack van Schijndel, A.J.M. Eerenberg-Belmer, L.G. Thijs, L.A.Aarden. Increased plasma levels of Interleukin-6 in sepsis. Blood 1989;74:1704-1710.

104. Nijsten, M.W.N., C.E. Hack, M. Helle, H.J. ten Duis, H.J. Klasen, L.A. Aarden, Interleukin-6 and its relation to the humoral immune response and clinical parameters in burned patients. Surgery 1991:109:761-767.

105. Yoshimura, N., T. Oka, B.D. Kahan. Sequential determinations of serum Interleukin-6 levels as an immunodiagnostic tool to differentiate rejection from nephrotoxicity in renal allograft patients. Transplantation 1991:51:172-176.

106. Coley, W.B. The treatment of malignant tumors by repeated inoculations of Erysipelas: with a report of ten original cases. Am. J. Med. Sci. 1893:5:487-511.

107. Coley, W.B. Late results of the treatment of inoperable sarcoma by the mixed toxins of erysipelas and bacillus prodigiosus. Am. J. Med. Sci. 1906;131:375-430.

108. O'Malley, W.E., B. Achinstein, M.J. Shear. Action of bacterial polysaccharide on tumors. II. Damage of sarcoma 37 by serum of mice treated with serratia marcescens polysaccharide, and induced tolerance. J. Natl. Cancer, I. 1962;29:1169-1175.

109. Pennica, D., G.E. Nedwin, J.S. Hayflick, P.H. Seeburg, R. Derynck, M.A. Palladino, W.J. Kohi, B.B. Aggarwal, D.V. Goeddel. Human Tumour Necrosis Factor: precursor structure, expression and homology to lymphotoxin. Nature 1984;312:724-729.

i i0. Beuller, B., J. Maboney, N. le Trang, P. Pekala, A. Cerami. Purification of Cachectin, a lipoprotein lipase-suppressing hormone secreted by endotoxin-induced RAW 264.7 cells. $J$. Exp. Med. 1985;161:984-995.

111. Mahoney, J.R., Jr., B.A. Beutler, N. le Trang, W. Vine, Y. Ikeda, M. Kawakami, A. Cerami. Lipopolysaccharide-treated RAW 264.7 cells produce a mediator that inhibits lipoprotein lipase in 3T3-LI cells. I. Immunol. 1985;134:1673-1675.

112. Beutler, B., D. Greenwald, J.D. Hulmes, M. Chang, Y.-C.E. Pan, J. Mathison, R. Ulevitch, A. Cerami. Identity of Tumour Necrosis Factor and the macrophage-secreted factor Cachectin. Nature 1985;316:552-554.

113. Ruddle, N.H., B.H. Waksman. Cytotoxicity mediated by soluble antigen and lymphocytes in delayed hypersensitivity. J. Exp. Med. 1968:128:1267-1279.

114. Granger, G.A., T.W. Williams. Lymphocyte cytotoxicity in vitro: activation and release of a cytotoxic factor. Nature 1968:218:1253-1254.

115. Li, C.-B., P.W. Gray, P.-F. Lin, K.M. McGrath, F.H. Ruddle, N.H. Ruddle. Cloning and expression of murine lymphotoxin cDNA. J. Immunol. 1987;138:4496-4501. 
116. Gray, P.W., B.B. Aggarwal, C.V. Benton, T.S. Bringman, W.J. Henzel, J.A. Jarett, D.W. Leung, B. Moffat, P. Ng, L.P. Svedersky, M.A. Palladino, G.E. Nedwin. Cloning and expression of cDNA for human lymphotoxin, a lymphokine with tumour necrosis activity. Nature 1984:312:721-724.

117. Shalaby, M.R., B.B. Aggarwal, E. Rinderknecht, L.P. Svedersky, B.S. Finkle, M.A. Palladino, Jr. Activation of human polymorphonuclear neutrophil functions by Interferon- $\gamma$ and Tumor Necrosis Factors. J. Immunol. 1985;135:2069-2073.

118. Macchia, D., F. Almerigogna, P. Parronchi, A. Ravina, E. Maggi, S. Romanani. Membrane Tumour Necrosis Factor- $\alpha$ is involved in the polyclonal B-cell activation induced by HIV. infected human T cells. Nature 1993;363:464-466.

119. Kriegler, M., C. Perez, K. DeFay, I. Albert, S.D. Lu. A novel form of TNF/Cachectin is a cell surface cytotoxic transmembrane protein: ramifications for the complex physiology of TNF. Cell 1988:53:45-53.

120. Jones, E.Y., D.I. Stuart, N.P.C. Walker. Structure of Tumour Necrosis Factor, Nature 1989;338:225-228.

121. Eck, M.J., B. Beutler, G. Kuo, J.P. Merryweather, S.R. Sprang. Crystallization of trimeric recombinant human Tumor Necrosis Factor (Cachectin). J. Biol. Chem. 1988;263:1281612819.

122. Alegre, M., P. Vandenabeele, V. Flamand, M. Moser, O. Leo, D. Abramowicz, J. Urbain, W. Fiers, and M. Goldman. Hypothermia and hypglycemia induced by anti-CD3 monoclonal antibody in mice: role of tumor necrosis factor. Eur. J. Immunol. 1990;20:707-710.

123. Manogue, K.R., S.J.H. van Deventer, A. Cerami. Tumour Necrosis Factor or Cachectin. In: the cytokine handbook, Chapter 12:241-256. Edited by Angus Thompson. London 1992 Academic press limited.

124. Debets, J.M.H., C.J. van der Linden, I.E.M. Dieteren, J.F.M. Leeuwenberg, W.A. Buurman. Fc-receptor cross-linking induces secretion of Tumor Necrosis Factor by monocytes. $J$. Immunol. 1988:141:1197-1201.

125. Debets, J.M.H., C.J. van der Linden, I.E.M. Spronken, W.A. Buuman. T-cell mediated secretion of Tumor Necrosis Factor by monocytes. Scand. J. Immunol. 1988;27:601-608.

126. Von Allmen, D., P. Hasselgren, T. Higashiguchi, J. Frederick, O. Zamir, J.E. Fisher. Increased intestinal protein synthesis during sepsis and following the administration of Tumour Necrosis Factor $\alpha$ or Interleukin-1 $\alpha$. Biochem. J. 1992:286:585-589.

127. Beutler, B., A. Cerami. Cachectin: more than a Tumor Necrosis Factor. New Engl. J. Med. 1987:316:379-385.

128. Millar, A.B., M. Singer, A. Meager, N.M. Foley, N.McI. Johnson, G.A.W. Rook. Tumour Necrosis Factor in bronchopulmonary secretions of patients with adult respiratory distress syndrome. Lancet 1989:712-714.

129. Tracey, K.J., A. Cerami. Cachectin/tumor necrosis factor and other cytokines in infectious disease. Curt. Opin. Immunol. 1989;1:454-461.

130. Lienard, D., F. Lejeune, J. Delmotte, N. Renard, P. Ewalenko. High-dose recombinant Tumor Necrosis. Factoro in combination with Interferon gamma and Melphalan in isolation perfusion of the limbs for melanoma and sarcoma. J. Clin. Onc. 1992;10:52-60.

131. Van Ostade, X., P. Vandenabeele, B. Everaerdt, H. Loetscher, R. Gentz. M. Brockhaus, W. Lesslauer, J. Tavernier, P. Broukaer, W. Fiers. Human TNF mutants with selective activity on the p55 receptor. Nature 1993;361:266-269.

132. Beutler, B., I.W. Milsark, A.C. Cerami. Passive immunization against Cachectin/Tumor Necrosis Factor protects mice from lethal effect of endotoxin. Science 1985;229:869.87l. 
133. Echtenacher, B., W. Falk, D.N. Mlinnel, P.H. Krammer. Requirement of endogenous Tumor Necrosis Factor/Cachectin for recovery from experimental peritonitis. J. Immunol. 1990;145: 3762-3766.

134. Allendoerfer, R., D.M. Magee, J.G. Smith, L. Bonewald, J.R. Graybill. Induction of Tumor Necrosis Factor- $\alpha$ in murine Candida albicans infection. J. Inf. Dis. 1993:167:1168-1172.

135. Engelberts, L, A. Moller, G. J. M. Schoen, C. J. van der Linden, and W. A. Buurman. Evaluation of measurement of human TNF in plasma by ELISA. Lymphokine Res. 1991;10: 133-140.

136. Engelberts, I., S. Stevens, G. J. M. Francot, C. J. van der Linden, and W. A. Buurman. Evidence for different effects of soluble TNF-receptors on various TNF measurements in human biological fluids. Lancet. 1991:338:515-516.

137. Grell, M., P. Scheurich, A. Meager, K. Pfizenmaier. TR60 and TR80 Tumor Necosis Factor (TNF)-receptors can independently mediate cytolysis. Lymphokine Res. 1993;12:143-148.

138. Ding. A.H., F. Porteu. Regulation of Tumor Necrosis Factor receptors on phagocytes. P. Soc. Exp. Biol. Med. 1992;200:458-465.

139. Engelmann, H., D. Novick, and D. Wallach. Two tumor necrosis factor-binding proteins purified from human urine: evidence for immunological cross-reactivity with cell surface tumor necrosis factor receptors. J. Biol. Chem. 1990;265:1531-1536.

140. Nophar, Y.. O. Kemper, C. Brakebush, H. Engelmann, R. Zwang, D. Aderka, H. Holtman, and D. Wallach. Soluble forms of tumor necrosis factor receptors (TNF-Rs): the cDNA for the type I TNF-R, cloned using amino and sequence data of its soluble form, encodes both the cell surface and a soluble form of the receptor. EMBO J. 1990,9:3269-3278.

141. Schall, T.J., M. Lewis, K.J. Koller, A. Lee, G.C. Rice, G.H.W. Wong, T. Gatanaga, G.A. Granger, R. Lentz, H. Raab, W.J. Kohr, D.V. Goeddel. Molecular cloning and expression of a receptor for human Tumor Necrosis Factor. Cell 1990:61:361-370.

142. Heller, R.A., K. Song, M.A. Onash, W.H. Fisher, D. Chang, G.M. Ringold. Complementary DNA cloning of a receptors for Tumor Necrosis Factor and demonstration of a shed form of the receptor. Proc. Natl'. Acad. Sci. USA 1990;87;615I-6155.

143. Brockhaus, M., H. J. Schoenfeld, E. J. Schlaeger, W. Hunziker, W. Lesslauer, and H. Loetscher. Identification of two types of tumor necrosis factor receptors on human cell lines by monoclonal antibodies. Proc. Natl. Acad. Sci. USA 1990;87:3127-3131.

144. Hohmann, H. P., R. Remy, M. Brockhaus, and A. P. G. M. van Loon. Two different cell types have different major receptors for human tumor necrosis factor (TNF $\alpha$ ). J. Biol. Chem. 1989:264:14927-14934.

145. Dembic, Z., H. Loetscher, U. Gubler, Y.-C.E. Pan, H.-W. Lahm, R. Gentz, M. Brockhaus, W. Lesslauer. Two human TNF receptors hace similar extracellular, but distinct intracellular, domain sequences. Cytokine 1990;2:231-237.

146. Loetscher, H., Y.-C.E. Pan, H.-W. Lahm, R. Gentz, M. Brockhaus, H. Tabuchi, W. Lesslauer. Molecular cloning and expression of the human $55 \mathrm{Kd}$ Tumor Necrosis Factor Receptor. Cell 1990,61:351-359.

147. Stauber, G.B., R.A. Aiyer, B.B. Aggarwal. Human Tumor Necrosis- $\alpha$ receptor. J. Biof. Chem. 1988:263:19088-19104.

148. Lewis, M., L.A. Tartaglia, A. Lee, G.L. Bennet, G.C. Rice, G.H.W. Wong, E.Y. Chen, and D.V. Goeddel. Cloning and expression of cDNAs for two distinct murine tumor necrosis factor receptors demonstrate one receptor is species specific. Proc. Natl. Acad. Sci. 1991;88: 28302834 .

149. Goodwin, R.G., D. Anderson, R. Jerzy, T. Davis, C.I. Brannan, N.G. Copeland, N.A. Jenkins, C.A. Smith. Molecular cloning and expression of the type 1 and type 2 murine receptors for Tumor Necrosis Factor. Mol. Cell. Biol. 1991:11:3020-3026. 
150. Smith, R.A., M. Kirstein, W. Fiers, C. Bagglioni. Species specificity of human and murine Tumor Necrosis Factor. J. Biol. Chem, 1986;261:14871-14874.

151. Tartaglia, L.A., D.V. Goeddel. Two TNF receptors. Immunol. Today 1992;13:151-153.

152. Tartaglia, L. A., R. F. Weber, I. S. Figari, C. Reynolds, M. A. Palladino, and D. V. Goeddel. The two different receptors for tumor necrosis factor mediate distinct cellular responses. Proc. Natl. Acad. Sci. USA. 1991,88:9292-9296.

153. Pfeffer, K., T. Matsuyama, T.M. Kündig, A. Wakeham, K. Kishihara, A. Shahinian, K. Wiegeman, P.S. Ohashi, M. Krönke, T.W. Mak. Mice deficient for the 55kD Tumor Necrosis Factor receptor are resistant to endotoxic shock yet succumb to L. monocytogenes infection. Cell 1993;73:457-467.

154. Tartaglia, L.A., M. Rothe, Y-F. Hu, D.V. Goeddel. Tumor Necrosis Factor's cytotoxic activity is signaled by the p55 TNF receptor. Cell 1993;73:213-216.

155. Heller, R.A., K. Song, N. Fan, D.J. Chang. The p70 Tumor Necrosis Factor receptor mediates cytotoxicity. Cell 1992;70:47-56.

156. Mackay, F., H. Loetscher, D. Stueber, G. Gehr, W. Lesslauer, Tumor Necrosis Factor $\alpha$ (TNF$\alpha$ )-induced cell adhesion to human endothelial cells is under dominant control of one TNF receptor type, TNF-R55. J. Exp. Med. 1993:177:1277-1286.

157. Abe, Y., M. Gatanaga, Y. Osuka, S. Kimura, R.A. Burger, G.A. Granger, T. Gatanaga. Role of 55- and 75-kDa Tumor Necrosis Factor membrane receptors in the regulation of intercellular Adhesion Molecule-1 expression by HL-60 human promyelocytic leukemia cells in vitro. J. Immunol. 1993;150:5070-5079.

158. Gehr, G., R. Gentz, M. Brockhaus, H. Loetscher, W. Lesslauer. Both Tumor Necrosis Factor receptor types mediate proliferative signals in human mononuclear cell activation. J. Immunol. 1992;149:911-917.

159. Vandenabeele, P., W. Declercq, D. Vercammen, M. v.d. Craen, J. Grooten, H. Loetscher, M. Brockhaus, W. Lesslauer, W. Fiers. Functional characterization of the human Tumor Necrosis Factor receptor p75 in a transfected rat/mouse T cell hybridoma. J. Exp. Med. 1992:176:10151024.

160. Seckinger, P., S. Isaaz, and J. M. Dayer. A human inhibitor of tumor necrosis factor- $\alpha . J$. Exp. Med. 1988;167:1511-1516.

161. Lantz. M., U. Gullberg, E. Nilsson, and I. Olsson. Characterization in vitro of a human tumor necrosis factor-binding protein. J. Clin. Invest. 1990;86:1396-/402.

162. Porteu, F., and C. Natan. Shedding of tumor necrosis factor by activated human neutrophils. J. Exp. Med. 1990; 172: 599-607.

163. Scannell, G., K. Waxman, G.J. Kaml, G. Ioli, T. Gatanaga, R. Yamamoto, G.A. Granger: Hypoxia induces a human macrophage cell line to release Tumor Necrosis Factor- $\alpha$ and its soluble receptors in vitro. I. Surg. Res. 1993;54:281-285.

164. Van Zee, K.J., T. Kohno, E. Fischer, C.S. Rock, L.L. Moldawer, S.F. Lewry. Tumor Necrosis Façtor soluble receptors circulate during exerimental and clínical inflammation and can protect against excessive Tumor Necrosis Factoro in vitro and in vivo. Proc. Natl. Acad. Sci. USA $1992,89: 4845-4849$.

165. Tan, L.R., K. Waxman, G. Scanell, G. Loli, G.A. Granger. Trauma causes early release of soluble receptors for Tumor Necrosis Factor. J. Trauma 1993;34:634-638.

166. Shapiro, L., B.D. Clark, S.F. Orencole, D.D. Poutsiaka, E.V. Granowitz, C.A. Dinarello. Detection of 'Tumor Necrosis Factor soluble receptor 555 in blood samples from healthy and endotoxemic humans. J. Inf. Dis. 1993;167:1344-1350.

167. Ashkenazi, A. S. A. Marsters, D. J. Capon, S. M. Chamov, I. S. Figari, D. Pennica, D. V. Goeddel, M. A. Palladino, and D. H. Smith. Protection against endotoxic shock by a Tumor Necrosis Factor receptor immunoadhesin. Proc. Natl. Acad. Sci. 1991:88:10535-10539. 
168. Gross, V., T. Andus, L. Caesar, M. Roth, J. Schölmerich. Evidence for continuous stimulation of Interleukin-6 production in Crohn's disease. Gastroenterology 1992;102:514-519.

169. MacDonald, T.T., P. Hutchings, M.-Y. Choy, S. Murch, A. Cooke. Tumour Necrosis Factor ad Interferon- $\gamma$ production measured at the single cell level in normal and inflamed human intestine. Clin. Exp. Immunol. 1990;81:301-305.

170. Maeda, M., N. Watanabe, H. Neda, N. Yamauchi, T. Okamoto, H. Sasaki, Y. Tsuji, S. Akiyama, Y. Tsuji, Y. Niitsu. Serum Tumor Necrosis Factor activity in inflammatory bowel disease. Immunopharm. Immunotox. 1992;14:451-461.

171. MeClain, C.J., D.A. Cohen. Increased Tumor Necrosis Factor production by monocytes in alcoholic hepatitis. Hepatology 1989;9:349-351.

172. Bird, G.L.A., N. Sheron, A.K. Goka, G.J. Alexander, R.S. Williams. Increased plasma Tumor Necrosis Factor in severe alcoholic hepatitis. Ann. Int. Med. 1990;112:917-920.

173. Schreiber, S., R.P. MacDermott, A. Raedler, R. Pinnau, M.J. Bertovich, G.S. Nash. Increased activation of isolated intestinal lamina propria mononuclear cells in inflammatory bowel disease. Gastroenterology 1991:101:1020-1030.

174. Koizumi, M., N. King, R. Lobb, C. Benjamin, D.K. Podolsky. Expression of vascular adhesion molecules in inflammatory bowel disease. Gastroenterology 1992;103:840-847.

175. Adams, D.H., E. Mainolfi, P. Burra, J.M. Neuberger, R. Ayres, E. Ellias, R. Rothlein. Detection of circulating intercellular adhesion molecule-1 in chronic liver diseases. Hepatology 1992:16:810-814.

176. Sprengler, U., A. Möller, M.C. Jung, G. Messer, R. Zachoval, R.M. Hoffmann, J. Eisenburg, G. Paumgartner, G. Rietmuller, E.H. Weiss, G.R. Pape. T lymphocytes from patients with primary biliary cirrhosis produce reduced amounts of Lymphotoxin, Tumor Necrosis Factor and Interferon- $\gamma$ upon mitogen stimulation. J. Hepatol. 1992;11:129-135.

177. Toth, C.A., P. Thomas. Liver endocytosis and Kupffer cells. Hepatology 1992;16:255-266.

178. Tanaka, N., S. Ryden, L. Bergqvist, P. Christensen, S. Bengmark. Reticulo-endothelial function in rats with obstructive jaundice. Br. J. Surg. 1985;72:946-949.

179. Clements, B., i. Halliday, M.D. McCaigue, R.G. Barclay, B.J. Rowlands. Effects of extrahepatic obstructive jaundice on Kupffer cell clearance capacity. Arch. Surg. 1993;128:200-205.

180. Zager, R.A. Escherichia coli endotoxin injections potentiate experimental ischemic renal injury. Am. J. Physiol. 1986;251:F988-F994.

181. Greve, J.W., D.J. Gouma, P.A.M. van Leeuwen, W.A. Buurman. Lactulose inhibits endotoxininduced tumour necrosis factor production by monocytes. An in vitro study. Gut 1990;31:198203.

182. Peetre, C., H. Thysell, A. Grubb, and I. Olsson. A tumor necrosis factor binding protein is present in human biological fluids. Eur. J. Haematol. 1988:41:414-419.

183. Pessina, G.P.. A. Pacini, V. Bocci, E. Maioli, A. Naldini, Studies on Tumor Necrosis Factor (TNF): II. Metabolic fate and ditribution of human recombinant TNF. Lymphokine Res. 1987;6:35-44.

184. Hession, C., J.M. Decker, A.P. Sherblom, S. Kumar, C.C. Yue, R.J. Mattaliano, R. Tizard, E. Kawashima, U. Schmeissner, S. Heletky, E.P. Chow, C.A. Burne, A. Shaw, A.V. Muchmore. Uromodulin (Tamm-Horsfall glycoprotein): a renal ligand for lymphokines. Science 1987;237: 1479.

185. Beutler, B.A., I.A. Milsark, A. Cerami. Cachectin/tumor necrosis factor: production, distribution, and metabolic fate in vivo. J. Immunol. 1985:135:3972-3977.

186. Cope, A.P., D. Aderka, M. Doherty, H. Engelmann, D. Gibbons, A.C. Jones, F.M. Brennan, R.N. Maini, D. Wallach, M. Feldmann. Increased levels of soluble Tumor Necrosis Factor receptors in the sera and synovial fluid of patients with rheumatic diseases. Arthritis Rheum. 1992;35:1160-1169. 
187. Alegre, M.L., P. Vandenabeele, M. Depierreux, S. Floquin, M. Deschodt-Lanckman, V. Flamand, M. Moser, O. Leo, J. Urbain, W. Fiers, M. Goldman. Cytokine release syndrome induced by the 145-2C11 anti-CD3 monoclonal antibody in mice: Prevention by high doses of methylprednisolone. J. Immunol. 1991;146:1184-1191.

188. Durez, P., D. Abramowicz, C. Gérard, M. van Mechelen, Z. Amraoui, C. Dubois, O. Leo, T. Velu, M. Goldman. In vivo induction of Interleukin-10 by anti-CD3 monoclonal antibody or bacterial lipopolysaccharide: differential modulation by cyclosporin A. J. Exp. Med. 1993:177: 551-555.

189. Chatenoud, L., C. Legendre, C. Ferran, J.F. Bach, H. Kreis. Corticosteroid inhibition of the OKT3-induced cytokine related syndrome. Dosage and kinetics prerequisites. Transplantation 1991:51:334-338.

190. Ferran, C., M. Dy, S. Merite, K. Sheehan, R. Schreiber, F. Leboulenger, P. Landais, J. Bluestone, J.F. Bach, L. Chatenoud. Reduction of morbidity and cytokine release in anti-CD3 MoAb-treated mice by corticosteroids. Transplantation. 1990;50:642-648. 


\section{Chapter 3}

\section{CYTOKINES TNF AND IL-6 IN BILIARY OBSTRUCTION IN MICE}

M.H.A. Bemelmans, J.W. Greve, D.J. Gouma, W.A. Buurman.

Hepatology 1992; 15:1132-1136 


\section{Abstract}

The putative role of the cytokines Interleukin-6 and Tumor Necrosis Factor in the pathophysiology of the complications and mortality after surgery in jaundiced patients was studied in a murine model. Cytokine serum levels were determined in mice with an experimental biliary obstruction. As indicator of the activation status of macrophages, cytokine release by mononuclear phagocytes obtained from such mice was assessed.

Following surgery Interleukin-6 levels increased to $2-3 \mathrm{ng} / \mathrm{ml}$ after 3-4 hours but declined rapidly afterwards to levels of $60 \mathrm{pg} / \mathrm{ml}$ after 10 days. After 12 days substantial Interleukin-6 levels were observed in jaundiced mice $(100 \mathrm{pg} / \mathrm{ml})$, while levels in sham mice further decreased $(\mathrm{p}<0.001)$. The cytokine Tumor Necrosis Factor was frequently present in the serum of jaundiced mice. After 22 days, at sacrifice, all jaundiced mice showed significant Tumor Necrosis Factor levels $(\mathrm{p}<0.001)$. This in contrast to sham mice in which Tumor Necrosis Factor was never detected.

The presence of an activated state of macrophages in jaundiced mice was concluded from the observed high spontaneous cytokine release and significantly higher release after stimulation $(\mathrm{p}<0.05)$.

The presence of circulating cytokines was discussed in the context of the postoperative complications observed in jaundiced patients.

\section{Introduction}

Under physiological circumstances minimal amounts of endotoxins, present in the gastrointestinal tract, are absorbed, and if absorbed they are effectively cleared by the reticuloendothelial system of the liver (1). In contrast, in jaundiced patients and in animals with experimental biliary obsiruction, endotoxemia occurs $(2,3)$.

Endotoxemia is known to induce release of inflammatory cytokines such as Tumor Necrosis Factor (TNF) and Interleukin-6 (IL-6), cytokines with plurifold properties. TNF and IL-6 possess multiple biological activities that affect a broad range of cells and elicit major changes in the biochemical " physiological and immunological status of the hosi $(4,5,6)$. These inflammatory cytokines are thought to play a major role in the pathophysiology of septic shock and multiple organ failure.

Endotoxemia has been considered to play a central role in the increased complication rate after surgery in obstructive jaundice $(7,8)$. Whether IL-6 and TNF are mediators of the increased complication rate after surgery in obstructive jaundice, which is considered to be related to endotoxemia, remains to be investigated. The objective of this study was to reveal whether biliary obstruction in an experimental murine model leads to circulating cytokine levels and activation of cytokine producing cells.

The data reported show that biliary obstruction in mice causes circulating TNF and IL-

6 levels and activation of macrophages. The relevance of these cytokines to the 
underlying mechanisms of complications seen after surgery in obstructive jaundice is discussed.

\section{Materials and methods}

Animals. Female Swiss mice weighing 27.5-34.5 grams were obtained from Charles River Breeding Laboratories. They were maintained on a standard laboratory diet and were allowed free access to water. University of Limburg criteria for care and use of laboratory animals in research were followed throughout.

Reagents. Lipopolysaccharide E.coli O55:B5 (LPS), phenol extracted (cat no. L2880), phorbol myristate acid (PMA), MTT (3-[4,5-dimethylthiazol-2-yl]-2,5diphenyltetrazolium bromide) and DMF ( $\mathrm{N}, \mathrm{N}$-dimethyl formamide) were obtained from Sigma (St Louis, MO). Culture medium consisted of RPMI 1640 (Gibco, Paisley, UK) supplemented with $10 \%$ bovine calf serum (Hyclone, Logan, UT), penicillin $100 \mathrm{U} / \mathrm{ml}$ and streptomycin $100 \mu \mathrm{g} / \mathrm{ml}$ (Flow, Irvine, U.K.).

TN3 (9), a hamster monoclonal antibody specific for murine TNF was a generous gift from Drs. K.C.F. Sheehan and R.D. Schreiber, St. Louis, MO, produced by Celltech Slough, UK. SDS (sodium dodecyl sulfate) was obtained from Bio-Rad (Richmond, CA).

Surgical procedures. Female Swiss mice $(n=96)$ were operated under a light ether anesthesia. They were divided at random in two groups, a sham operated control group and a biliary obstruction group. A mid-abdominal incision was made and the common bile duct was ligated and divided as described by Pinto (10). In mice undergoing a sham operation the bile duct was dissected, ligatures were placed but not tied and removed again.

Experimental procedure. The biliary obstructed and sham mice were divided in 4 groups of 24 mice, which were operated on 4 consecutive days. In each group, 12 mice were used to measure TNF and triglycerides and 12 to measure IL 6 and bilirubin to reduce the amount of blood taken from each mouse individually. Pre-operative blood samples $(200 \mu \mathrm{l})$ were obtained by orbital puncture at least 3 days before operation. From the group operated on day 1 (group 1), blood was taken at day 4,7,10,14,18,22. From group 2 at day $3,6,8,13,17,22$; from group 3 at day $2,5,9,12,16,22$; from group 4 at day $1,4,11,15,22$. At 22 days animals were sacrificed and blood samples were collected under ether anesthesia. At the end of the experiment peritoneal macrophages were harvested. The data of the cytokines IL-6, TNF and other parameters were determined day by day by pooling data of the 4 groups. At 22 days jaundice in the biliary obstructed mice was confirmed by measuring bilirubin. Ten mice died during the experiment ( 7 biliary obstructed mice and 3 sham mice).

Body weights of the mice in both groups were recorded on day $0,7,14$ and 22 . 
To measure IL-6 and TNF during the first hours after the operation a separate group of 24 mice was randomized in biliary obstruction or sham. At 2,4,8 hours after the operation approximately $150 \mu \mathrm{l}$ of blood was collected.

Bloodchemistry. Bilirubin was determined with a Cobas Bio (Hoffman La Roche, Basle, Switzerland), using the bilirubin test (Hoffman La Roche, Basle, Switzerland).

Enzyme linked immunosorbent assay (ELISA) for murine TNF. Elisa for murine TNF was performed as described earlier by Dentener (11). A hamster anti-murine TNF monoclonal (TN3) was used as capture antibody and a polyclonal rabbit anti-murine TNF (Genzyme) as second antibody. The elisa has a lower detection limit of $50 \mathrm{pg} / \mathrm{ml}$.

Bioassay for $I L-6$. Serum IL-6 activity was measured by bioassay using an IL-6 dependent B9 hybridoma cell-line (12) (a generous gift from Dr. L. Aarden, CLB, Amsterdam, The Netherlands) and proliferative activity was estimated using the MTT method (13). The detection limit of the bioassay is $5 \mathrm{pg} / \mathrm{ml}$.

Culture of peritoneal macrophages. Peritoneal macrophages were adjusted to $2 \times 10^{5}$ cells $/ \mathrm{ml}$. Cells were incubated in 96-well flat-bottom plates $(200 \mu \mathrm{l} /$ well). LPS was added at $10 \mathrm{pg} / \mathrm{mi}, 10 \mathrm{ng} / \mathrm{ml}$ and $500 \mathrm{ng} / \mathrm{ml}$ and PMA at $10 \mathrm{ng} / \mathrm{ml}$. Supernatants were harvested after 18 hours of culture. For TNF assessment, all individual supernatants were measured, data were pooled and mean \pm SEM was determined. For IL-6 measurement, supernatants of 6 mice were pooled and assayed in duplicate. The obtained data were pooled and mean \pm SEM was determined.

Statistical analysis. (14) Results are presented as means \pm 1 SD unless stated otherwise. Statistical differences between the means of hematological data, chemical data, cytokine production by macrophages and serum TNF in timegroups were analyzed with the Wilcoxon rank-sum test. Analysis of variance (ANOVA) was used for comparison of differences in serum cytokine levels and bodyweights. Probability $(p)$ values below 0.05 were considered to be statistically significant.

\section{Results}

Confirmation of jaundice. At the end of the experiment jaundice was confirmed by determining serum bilirubin levels. Serum bilirubin levels increased rapidly after the operation and after 22 days bilirubin levels were $3.47 \pm 0.67 \mu \mathrm{mol} / \mathrm{l}$ for sham mice vs $348 \pm 146.7 \mu \mathrm{mol} / \mathrm{h}$ for biliary obstructed mice $(\mathrm{p}<0.001)$ (Fig 1).

Preoperative bodyweight of sham mice was $30.9 \pm 2.1$ grams vs $31.1 \pm 2$ grams for biliary obstructed mice. A. considerable weight loss was observed after the operation in both groups (data not shown). Bodyweight after 7 and 14 days was respectively $28.3 \pm 1.6$ and $28.9 \pm 1.9$ in sham mice and $26.7 \pm 1.6$ and $25.8 \pm 1.9$ in biliary obstructed mice. After 
22 days at sacrifice, there was a significant weight difference between sham and biliary obstructed mice (respectively $29.1 \pm 1.7$ grams vs $26.9 \pm 2.6$ grams; $p<0.01$ ). The hematocrit of biliary obstructed mice was significantly lower compared to sham mice (respectively $35 \pm 3 \%$ vs $46 \pm 2.3 \%$, p $<0.001$ ).

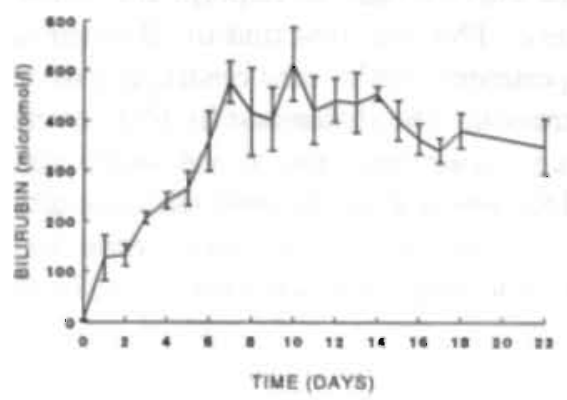

Circulating $I L-6$. Before operation none of the mice had circulating IL-6 levels. Directly following surgery IL-6 levels increased in both biliary obstructed and sham mice. Highest levels were found 3-4 hours after the operation with peak levels of 2500 units/ml for biliary obstructed mice and 1300 units/mi for sham mice. At the end of day 1 the levels declined, although IL-6 levels of biliary obstructed mice diminished seemingly slower. After 5 days IL-6 levels of sham mice retumed to less than 50 units $/ \mathrm{ml}$ and diminished subsequently to 10 units/ml or less after 13-15 days. In the biliary obstructed mice, substantial IL-6 levels were observed from day 12 onwards.

In the period from day 5-22, using analysis of variance, the later IL-6 levels of sham mice are significantly lower than the earlier samples $(\mathrm{p}<0.0$ $01)$. The difference between the biliary obstructed mice and the sham mice was statisticaly significant ( $<<0.001)$ (Fig 2 ).
Figure 1: Bilirubin levels in biliary obstructed mice during 22 days. Data are means \pm SEM.
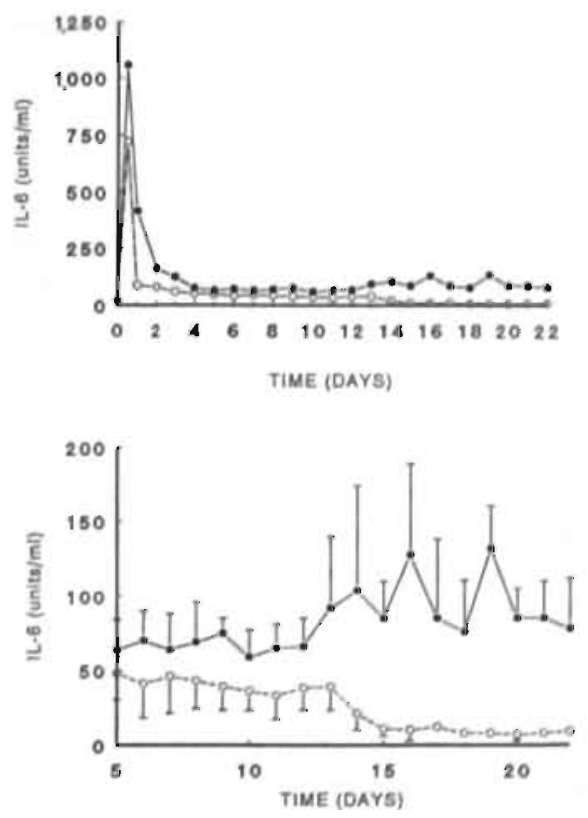

Figure 2: IL-6 serumconcentrations in biliary obstructed (-) and sham mice (G). Upper graph shows IL-6 levels during the whole experiment (SD not given for clarity). Lower graph gives an exploded view of the IL-6 levels from 5-22 days, data are expressed as means $\pm \mathrm{SD}$. 
Circulating TNF. Circulating TNF levels were below detection limit at the onset of the experiment in both biliary obstructed and sham mice. In the sham operated group, TNF was never detected during the experiment. In contrast, in biliary obstructed mice TNF was found from the first postoperative day onwards (Fig 3a).

A considerable variation between the individual mice was observed. In $68 \%$ of the biliary obstructed mice, TNF was detected at least once during the experiment before sacrifice (range $52-2925 \mathrm{pg} / \mathrm{ml}$ ). In $20 \%$ of the mice, TNF was detected in all samples taken from the first postoperative day of the experiment. All biliary obstructed mice had detectable TNF levels at the end of the experiment. The difference in TNF levels between biliary obstructed mice and sham mice, using analysis of variance, was statistically significant ( $<<0.001$ ). Fig $3 \mathrm{~b}$ shows TNF levels after dividing the mice into timegroups. In every timegroup only one sample per mouse has been taken and statistical differences were determined using the Wilcoxon rank-sum test. Significant differences were reached in every timegroup.

Figure 3: TNF serumconcentrations in biliary obstructed and sham mice.

a) TNF levels of each individual mouse. At each on the $\mathrm{X}$-axis indicated timepoint, at least. 5 biliary obstructed mice and 6 sham mice were investigated. TNF levels of sham mice were all below detection level and therefore not indicated. The number of biliary obstructed mice mice with TNF levels below detection level are indicated in the box below the graph. At the end of the experiment day 22, all biliary obstructed mice were investigated. The lower detection limit of TNF was $50 \mathrm{pg} / \mathrm{ml}$.

b) Serum TNF levels in biliary obstructed and sham mice, divided into timegroups. Open bars represent TNF levels in sham mice, hatched bars TNF levels in BDL mice. Timegroup 0: sham $(n=22)$, bile duct ligated $(B D L)$ mice $(n=26) ; 1-4$ days: sham $(n=22)$, BDL $(n=26)$; 4-7 days: sham $(n=22)$, BDL $(n=26) ; 8-11$ days: sham $(n=22), B D L(n=26) ; 12-15$ days: sham $(n=21)$, BDL $(n=26)$; $16-18$ days: sham $(n=17), B D L(n=19) ; 19-22$ days (in the graph indicated as 22 days): sham $(n=21), B D L$ $(n=23)$, In every timegroup only one sample per mouse has been taken. Data are expressed as means \pm SEM; $*=p<0.05, \quad * *=p<0.01$, $* *=0<0.001$ (Wilcoxon rank-sum test). Horizontal line at $50 \mathrm{pg} / \mathrm{ml}$ represents detection limit.
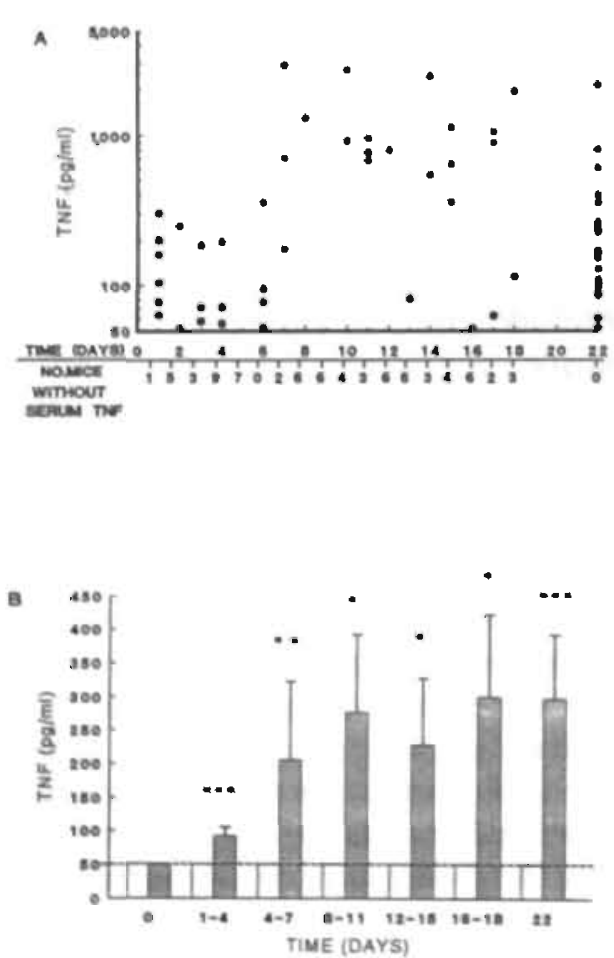
In vitro cytokine production by peritoneal macrophages. Spontaneous and induced IL-6 and TNF release by peritoneal macrophages was determined at the end of the experiment. Spontaneous IL-6 release of peritoneal macrophages of biliary obstructed mice $(47.5 \pm 20.4$ units $/ \mathrm{ml})$ was not significantly different from the macrophages of sham mice $(11.2+2.4$ units/ml; p=0.11). Stimulation with $10 \mathrm{pg} / \mathrm{ml}$ LPS or $10 \mathrm{ng} / \mathrm{ml}$ LPS induced a significantly higher IL-6 release by macrophages of biliary obstructed mice compared to sham mice ( $\mathrm{p}<0.05$ ). Maximum IL- 6 levels were reached when stimulated with $500 \mathrm{ng} / \mathrm{ml}$ LPS (Fig 4). Biliary obstructed mice reached IL-6 levels of $963 \pm 188$ units $/ \mathrm{ml}$ and sham mice reached a maximum IL-6 level of $638 \pm 135$ units $/ \mathrm{ml}$, although significance was not reached $(\mathrm{p}=0.2)$. Also the difference between PMA enhanced release of IL -6 by macrophages of biliary obstructed and sham mice did not reach significance.

Spontaneous TNF release by macrophages of biliary obstructed mice showed significantly higher TNF release $(2760 \pm 1298 \mathrm{pg} / \mathrm{ml})$ than sham mice $(94.2 \pm 24.5 \mathrm{pg} / \mathrm{ml}$; $\mathrm{p}<0.05$ ). Stimulation of the macrophages with LPS in concentrations of $10 \mathrm{ng} / \mathrm{ml}$ or $500 \mathrm{ng} / \mathrm{ml}$ induced an increase in TNF release by macrophages of both biliary obstructed and sham mice (Fig 4).

LPS induced TNF release by macrophages of biliary obstructed mice was significantly higher than that of sham mice $(\mathrm{p}<0.05)$. Similarly, stimulation with PMA induced a significantly increased TNF release by macrophages of biliary obstructed mice when compared to those of sham mice $(\mathrm{p}<0.05)$.

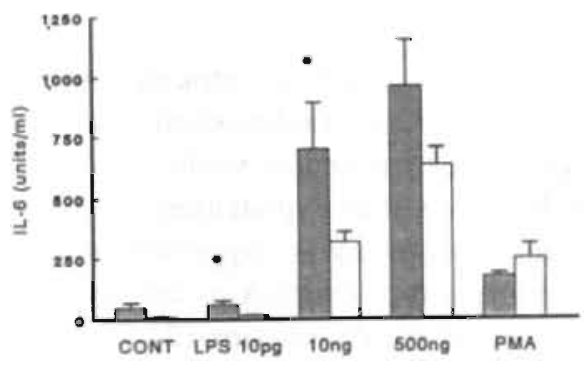

Figure 4: IL-6 and TNF production by peritoneal macrophages. Hatched bars represent cytokine levels in biliary obstructed mice, open

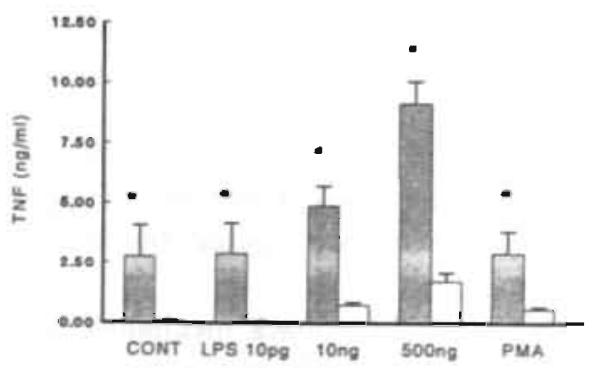
bars represent cytokine levels in sham operated mice. Peritoneal macrophages were cultured for 18 hours, non stimulated, stimulated with LPS $10 \mathrm{pg} / \mathrm{ml}$, LPS $10 \mathrm{ng} / \mathrm{ml}$, LPS $500 \mathrm{ng} / \mathrm{ml}$ or with PMA $10 \mathrm{ng} / \mathrm{ml}$. The upper graph gives IL -6 release by the peritoneal macrophages, the lower graph gives the TNF release. Data are expressed as means \pm SEM. Significant difference indicated: $*=p<0.05$ in relation to identical experiments in sham mice. 


\section{Discussion}

Bile duct obstruction in mice was used as a model to study effects of obstructive jaundice. Jaundice was confirmed by high bilirubin levels. The observed initial weight loss and reduced hematocrit are supported by data in rats reported by Greve and Holman $(7,15)$. The data presented show that substantial cytokine levels were present in biliary obstructed mice. An initial rise in IL-6 levels was observed in both the experimental and sham group with a peak round 3-4 hours after the operation, which declined rapidly afterwards. A similar increase in circulating IL-6 levels was found after elective surgery in man $(16,17)$. It is suggested therefore that the operation trauma in our mice was responsible for the initial rise in circulating IL-6. From day 12 onwards all biliary obstructed mice showed high IL-6 levels. Furthermore significant TNF levels were present in a large proportion of the biliary obstructed mice. The observed wide diversity of TNF levels may be due to the fact that TNF production is not a continuous process, but rather a process of which is known that a rather rapid increase and decline occurs. Therefore, the data reflect the presence of TNF at the moment of sampling. A similar wide variety in TNF levels was found by Greve et al. in biliary obstructed rats after renal ischemia (8):

In order to determine whether the presence of circulating cytokines was accompanied by the presence of activated macrophages, we measured spontaneous and stimulated release of TNF and IL-6 by peritoneal macrophages. Peritoneal macrophages of biliary obstructed mice showed a higher spontaneous and stimulated cytokine release than sham mice for TNF and to a lesser degree for IL-6, indicating an activated state of these cells.

The presence of the activated status of macrophages and the systemic cytokine levels in biliary obstructed mice may be caused by several mechanisms. Endotoxemia, portal as well as systemic, which has been demonstrated in experimental studies and in patients with obstructive jaundice $(2,3,18)$, may be a possible explanation for our observations. Based on in vitro data $(19,20,21)$, endotoxemia was suggested to be caused by several mechanisms such as increased absorption of endotoxins due to the absence of bile acids, which function as dispersing agent for endotoxins $(22,23,24)$. Also a decreased Kupffer cell clearance of lipopolysaccharides due to high plasma bile acid levels was reported to explain endotoxemia $(3,25)$. Furthermore, biliary obstruction affects excretion of $\operatorname{IgA}$ leading to reduced $\operatorname{IgA}$ levels in the gut $(26,27)$. A causative relationship however, between endotoxemia and the diminished biliary excretion of IgA has not been shown.

Recently we reported that bile acids, especially deoxycholic acid, reduce the release of TNF in response to endotoxin (28). The absence of bile acids in the gut of the biliary obsiructed mice may therefore underlay cytokine release caused by local endotoxins, responsible for the observed cytokine levels.

The TNF release is known to be counterregulated via several feedback mechanisms, in which the pituitary adrenal axis, prostaglandins, corticosteroids and a negative 
feedback of IL-6 on TNF play a role (29-34). The data therefore suggest that the obstructive jaundice interfered with the normal feedback mechanisms for TNF release. The data presented show, that obstructive jaundice in mice leads to prolonged increased levels of the cytokines TNF and IL-6, which have been shown to be related to the pathogenesis of multiple organ failure and adult respiratory distress syndrome (35). The presence itself of the cytokines in jaundiced mice seems not to be sufficient to trigger substantial morbidity. However, recent clinical data obtained from patients which were treated with TNF have indicated that TNF has a pathogenetic role in abnormalities of liver function and in cholestasis (36). It has to be elucidated in animal experiments, if the observed increase of complications following surgery in obstructive jaundice is mediated by the presence of these cytokines. Furthermore has to be studied if this complication rate can be altered by interference in the cytokine metabolism. 


\section{References}

1. Nolan, J.P. Endotoxin, reticuloendothelial function, and liver injury. Hepatology 1981;1:458465.

2. Gouma, D.J., J.C.U. Coelho, J.D. Fisher, J.F. Schlegel, Y.F. Li, F.G. Moody. Endotoxemia after relief of biliary obstruction by internal and external drainage in rats. Am. J. Surg. 1986:151:476-479.

3. Van Bossuyt, H., C. Desmaretz, G.B. Gaeta, E. Wisse. The role of bile acids in the development of endotoxemia during obstructive jaundice in the rat. J. Hepatol. 1990;10:274-279.

4. Beutler, B., A. Cerami. Cachectin: More than a tumor necrosis factor. N. Engl. J. Med. 1987:316:379-385.

5. Beutler, B., J. Mahony, N. Le Trang, P. Pekala, A. Cerami. Purification of cachectin,a lipoprotein lipase-suppressing hormone secreted by endotoxin induced raw 264.7 cells. J. Exp. Med. 1985:161:984-995.

6. Sehgal, P.B. Interleukin-6: a regulator of plasma protein gene expression in hepatic and nonhepatic tissues. Mol. Biol. Med. 1990;7:117-130.

7. Greve, J.W., D.J. Gouma, P.B. Soeters, W.A. Buurman. Suppression of cellular immunity in obstructive jaundice is caused by endotoxins. A study in germfree rats. Gastroenterology 1990,98:478-485.

8. Greve, J.W., J.G. Maessen, T. Tiebosch, W.A. Buurman, D.J. Gouma. Prevention of postoperative complications in jaundiced rats; internal biliary drainage versus oral lactulose. Ann. Surg, 1990;212:221-227.

9. Sheehan, K.C.F., N.H. Ruddle, R.D. Schreiber. Generation and characterisation of hamster monoclonal antibodies that neutralizes Murine Tumor Necrosis Factors. J. Immunol. 1989; 142:3884.

10. Pinto, M., A. Kaplun. Immune status in mice with experimental biliary obstruction. Clin. Immunol. Immunopath. 1980;16:396-405.

11. Dentener, M.A. J.W. Greve, J.G. Maessen, W.A. Buturman. Role of tumor necrosis factor in the phenomenon of the enhanced sensitivity of animals to endotoxin after exposure to lead. immunopharm. Immunot, 1989:11:321-324.

12. Aarden, L.A., E.R. De Groot, O.L. Schaap, P. Lansdorp. Production of hybridoma growth factor by human monocytes, Eur. J. Immunol. 1987;17:1411.

13. Hansen, M.B., S.E. Nielsen, K. Berg. Re-examination and further development of a precise and rapid dye method for measuring cell growth/cel kill. J. Immunol. Methods 1989;119:203210 .

14. Norusis, M.J. ed. SPSS/PC+ V3.1 BASE MANUAL for the IBM PC/XT/AT and PS/2. SPSS Inc., Chicago, USA.

15. Holman, J.M., L.F. Rikkers. Biliary obstruction and host defense failure. J. Surg. Res. 1982;32:208-213.

16. Pullicino, E.A., F. Carli, S. Poole, B. Rafferty, S.T.A. Malik, M. Elia. The relationship between the circulating concentrations of interleukin-6 (IL-6), tumor necrosis factor (TNF) and the acute phase response to elective surgery and accidental injury. Lymphokine Res. 1990:9:231-238.

17. Shenkin, A., W.D. Fraser, J. Series, A.C. Winstanley, H. McCartney, H. Burns, J. Van Damme. The serum Interleukin-6 response to elective surgery. Lymphokine Res. 1989;8:123127.

18. Pain, J.A., M.E Bailey. Measurement of operative plasma endotoxin levels in jaundiced and non-jaundiced patients. Eur. Surg. Res, 1987:19:207-216. 
19. Tarmina, D.F., K.C. Milner, E. Ribi, J.A. Rudbach. Reaction of endotoxins and surfactants. Immunologic properties of endotoxins treated with sodiumdeoxycholate. I. Immunol. 1968:100:444-450.

20. Shands, J.W., P.W. Chun. The dispersion of gram-negative lipopolysaccharide by deoxycholate. J. Biol. Chem. 1980;255: 1221-1226.

21. Ribi, E., R.L. Anacker, R. Brown, et al. Reaction of endotoxin and surfactants I. Physical and biological properties of endotoxin treated with sodium deoxycholate. J. Bacteriol. 1966;92: 1493-1509.

22. Bailey, M.E. Endotoxin, bile salts and renal function in obstructive jaundice, Br. J. Surg. 1976,63:774-778.

23. Bertok, L. Physico-chemical defense of vertebrate organisms: the role of bile acids in defense against bacterial endotoxins. Perspect. Biol. Med. 1977:70-76.

24. Deventer, van S.J.H., J.W. ten Cate, G.N.J. Tytgat. Intestinal endotoxemia. Gastroenterology $1988,94: 825-831$.

25. Fox, E.S., P. Thomas, S.A. Broitman. Clearance of gut-derived endotoxins by the liver. Gastroenterology 1989,96:456-461.

26. Lemaitre-Coelho, I., G. Jackson, J.P. Vaerman. High serum levels of secretory IgA and free secretory component in the serum of rats with biliary obstruction. J. Exp. Med. 1978:147:934. 939.

27. Harmatz, P., R. Kleinman, B. Bunnell, D. McClenathan, W. Walker, K. Bloch. The effect of bile duct obstruction on the clearance of circulating IgA immune complexes. Hepatology 1984,4:96-100.

28. Greve, J.W., D.J. Gouma, W.A. Buurman. Bile acids inhibit endotoxin induced release of tumor necrosis factor by monocytes. Hepatology 1989;10:454-458.

29. Kunkel, S., R.C. Wiggins, S.W. Chensue, J. Larrick. Regulation of macrophage tumor necrosis factor production by prostaglandin $\mathrm{E}_{2}$. Biochem. Biophys. Res. Comm. 1986;137:4041.410.

30. Zuckerman, S.H., J. Shellhaas, L.D. Butler. Differential regulation of lipopolysaccharideinduced interleukin 1 and tumor necrosis factor synthesis: effects of endogenous and exogenous glucocorticoids and the role of the pituitary-adrenal axis. Eur. I. Immunol. 1989:19:301. 305.

31. Schindler, R., J. Mancilla, S. Endres, R. Ghorbani, S.C. Clark, C.A. Dinarello. Correlations and interactions in the production of interleukin-6 (IL-6), IL-1, and tumor necrosis factor (TNF) in human blood mononuclear cells: IL-6 suppresses IL-1 and TNF. Elood 1990:1:4047.

32. Bertini, R., M. Bianchi, A. Erroi, P. Villa, P. Ghezzi. Dexamethasone modulation of in vivo effects of endotoxin, tumor necrosis factor, and interleukiri-1 on liver cytochrome P-450. plasma fibrinogen, and serum iron. J. Leukocyte Biol. 1989;46:254-262.

33. Mathison, J.C. G.D. Virca, E. Wolfson, P.S. Tobias, K. Glaser, R.J. Ulevitch. Adaptation to bacterial lipopolysaccharide controls lipopolysaccharide-induced tumor necrosis factor production in rabbit macrophages. J. Clin. Invest. 1990;85:1108-1118.

34. Remick, D.G., R.M. Strieter, J.P. Lynch III, D. Nguyen, M. Eskandari, S.L. KunkeI. In vivo dynamics of murine tumor necrosis factor alpha gene expression: kinetics of dexamethasoneinduced suppression. Lab. Invest 1989;60:766-771.

35. Waage, A., A. Halstensen, T. Espevik. Association between tumor necrosis factor in serum and fatal outcome in patients with meningococcal disease. Lancer 1987;1:355-357.

36. Jones, A., P.J. Selby, C. Viner, S. Hobbs, M.E. Gore, T.J. McElwain. Tumour necrosis factor, cholestatic jaundice, and chronic liver disease. Gut 1990;31:938-939. 



\section{Chapter 4}

\section{THE EFFECT OF ANTI-TNF TREATMENT ON}

CIRCULATING TUMOR NECROSIS FACTOR AND MORTALITY AFTER SURGERY IN JAUNDICED MICE

M.H.A. Bemelmans, J.W. Greve, D.J. Gouma, W.A. Buurman.

Br. J. Surg. 1993;80:1055-1058 


\begin{abstract}
Tumor Necrosis Factor may play an important role in the increased incidence of postoperative complications after surgery in patients with obstructive jaundice. This study evaluates the effect of different anti-TNF treatments, a monoclonal anti-TNF antibody (TN3), pentoxifylline and lactulose on the outcome after a severe surgical trauma in mice with experimental biliary obstruction. Circulating serum TNF levels and mortality were monitored.

Severe surgical trauma, such as renal ischemia in jaundiced mice results in increased levels of circulating TNF ( $3.5 \mathrm{ng} / \mathrm{ml})$ and a high mortality $(54 \%)$. Three different antiTNF treatments resulted in significant reduction of postoperative levels of circulating TNF (TN3 and pentoxifylline $\mathrm{p}<0.01$ and lactulose $\mathrm{p}<0.05$ ). Treatment with TN3 and pentoxifylline did not lead to al significant reduced mortality (36\% and $44 \%)$. Only lactulose resulted in significant reduced mortality $(7 \% ; \mathrm{p}<0.01)$. TNF is not the only mediator responsible for mortality after surgery in jaundiced mice. Other mechanisms which are affected by lactulose are involved.
\end{abstract}

\title{
Introduction
}

Surgery in patients with obstructive jaundice is associated with significant morbidity and a high incidence of infectious complications (1-3). Several underlying mechanisms may play a part in this phenomenon such as high serum bilirubin and bile acid levels (4), depressed immune function (5-9), poor nutritional status (10,11) and endotoxemia $(2,12-15)$. Internal or external biliary drainage, bile acid or mannitol administration and oral lactulose have been studied in the prevention of these complications but without substantial benefit $(7,15-24)$.

Endotoxemia in humans and animals with biliary obstruction correlates with the occurrence of postoperative complications $(14,20,25)$. Endotoxennia results in circulating Tumor Necrosis Factor (TNF), a central mediator of endotoxin toxicity (26). Circulating TNF can be detected in mice with experimental biliary obstruction and may play a role in the pathogenesis of the complications seen after surgery (27).

This study compared the effects of different treatments which interfere with either the effects of TNF or the release of TNF in mice with biliary obstruction with bilateral renal ischemia as a severe surgical trauma. The effects on circulating TNF and mortality were studied. The anti-TNF agents used were a monoclonal anti-TNF antibody (TN3), pentoxifylline which is known to inhibit TNF release in vitro and in vivo without affecting interleukin-6 release $(28,29)$ and oral lactulose which has been shown to reduce Lipopolysaccharide (LPS) induced TNF production in vitro (30). 


\section{Materials and methods}

Animals. Female Swiss mice weighing 27.5-34.5 grams (Charles River Breeding Laboratories, Heidelberg, FRG) were maintained on a standard laboratory diet and were allowed free access to water.

Reagents. Bovine Serum Albumin (BSA), 3-[4,5-dimethylthiazol-2-yl]-2,5 diphenyltetrazolium bromide (MTT), N,N-dimethyl formamide (DMF) and substrate O-PhenylDiamine (OPD) were obtained from Sigma (St Louis, MO). TN3 (31), a hamster monoclonal antibody specific for murine TNF was a generous gift from Drs K.C.F. Sheehan and R.D. Schreiber, St Louis, MO, produced by Celltech, Slough, UK. Sodium dodecyl sulfate (SDS) was obtained from Bio-Rad (Richmond, CA). Peroxidase conjugated goat anti rabbit IgG was obtained from Jackson (Westgrove, PA). Polyclonal rabbit anti-murine TNF antiserum (RAMT) was produced by injecting rabbits with murine TNF kindly provided by Knoll/BASF (Ludwigshafen,FRG). Pentoxifylline was donated by Hoechst (Wiesbaden, FRG). Lactulose (Duphalac) was a kind gift from Duphar (Weesp, The Netherlands).

Surgical procedures. Female Swiss mice were operated under light ether anesthesia on a temperature controlled watermattress. Through a $1.0 \mathrm{~cm}$ long mid-abdominal incision the common bile duct was ligated and divided as a modification (27) of the method of Pinto (6). After surgery all mice received $1 \mathrm{ml}$ saline subcutaneously.

Renal ischemia (RI) was performed 18 days after bile duct ligation (BDL). Mice were anesthetized with ether and the renal vascular pedicles were clamped for 30 minutes with soft tip clamps to cause renal ischemia. During the ischemic period the abdomen was closed, ether anesthesia interrupted and the animals allowed to recover. In sham operated mice the renal vessels were dissected but not clamped. After 30 minutes of (sham) ischemia, the abdomen was opened again (also in the sham group) and clamps were removed (or "sham" removed). After macroscopic confirmation of reperfusion, the abdomen was closed. Blood was obtained by puncture of the retrobulbar venous plexus.

Experimental design. After BDL, mice were randomly divided into 5 experimental groups (Table 1). RI was performed at day 18. Group 1 received sham RI (BDLSHAM). Group 2 received RI without pretreatment (BDL-RI). Group 3 received antiTNF antibody (TN3), $0.5 \mathrm{mg}$ per mouse before RI (BDL-TN3). Group 4 received pentoxifylline preoperatively $1 \mathrm{mg} /$ mouse (BDL-pentox) and group 5 received oral lactulose (Duphalac; BDL-DUPH) before RI. TN3 was given intraperitoneally 4 hours before ischemia. Group 4 received pentoxifylline at $t=-2$ hours intraperitoneally. Group 5 was treated for three days with oral lactulose $(0.25 \mathrm{ml} 30 \%$ Duphalac syrup in water) twice daily before RI. Blood was sampled one day before ischemia and 1.5 hour after ischemia (time of TNF peak; unpublished data). After blood collection all mice received $1 \mathrm{ml}$ saline subcutaneously. 
Previous experiments have shown that after 18 days all mice have substantial plasma levels of bilirubin (27). Bilirubin levels were measured in randomly selected blood samples of 27 mice taken 1 day before ischemia to assure biliary obstruction (mean $349 \pm 31 \mu \mathrm{mol} / \mathrm{l})$. Animals with bile leakage or which did not survive 1.5 hours after RI were excluded. This led to an unequal distribution of animals over the different groups. Survival was monitored for 5 days after RI (day 23) in a so called "steady state" obstructive jaundice to prevent interference of mortality of end stage biliary obstruction (occurring 25 days after biliary obstruction).

Table 1. Experimental Design*

\begin{tabular}{llllll}
\hline & $\begin{array}{l}\text { Group 1 } \\
\text { BDi-SHAM } \\
(\mathrm{n}=10)\end{array}$ & $\begin{array}{l}\text { Group 2 } \\
\text { BDL-RI } \\
(\mathrm{n}=13)\end{array}$ & $\begin{array}{l}\text { Group 3 } \\
\text { BDL-TN3 } \\
(\mathrm{n}=11)\end{array}$ & $\begin{array}{l}\text { Group 4 } \\
\text { BDL-PENTOX } \\
(\mathrm{n}=9)\end{array}$ & $\begin{array}{l}\text { Group 5 } \\
\text { BDL-DUPH } \\
(\mathrm{n}=14)\end{array}$ \\
\hline Day 0 & BDL & BDL & BDL & BDL & BDL \\
Day 15 & - & - & - & - & DUPH \\
Day 16. & - & - & - & - & DUPH \\
Day 17 & - & - & - & - & DUPH \\
Day 18 & SHAM-RI & RI & TN3-RI & PENTOX-RI & DUPH-RI \\
\hline
\end{tabular}

$\mathrm{BDL}=$ bile duct ligation, $\mathrm{RI}=$ renal ischemia, $\mathrm{TN} 3=$ monoclonal anti-TNF antibody, Pentox= pentoxifylline, Duph= Duphalac (lactulose). Serum TNF was measured by ELISA 90 minutes after reperfusion. Survival was assessed during 120 hours.

Enzyme !inked immunosorbent assay (ELISA) for murine TNF. ELISA was performed as described by Dentener (32). The ELISA had a lower detection limit of $50 \mathrm{pg} / \mathrm{ml}$ TNF,

Statistical analysis. Differences in serum TNF levels were calculated using analysis of variance (ANOVA, 33). Significance levels for differences in mortality between treatment groups were determined by the log rank test. Data are expressed as means \pm SEM unless stated otherwise. Probability values below 0.05 were considered to be statistically significant. 


\section{Results}

Serum TNF values before and after renal ischemia in BDL mice. Preoperative blood samples, collected one day before RI, 17 days after BDL, showed that significant levels of TNF were circulating in the majority of the mice with an average TNF level of approximately $250 \mathrm{pg} / \mathrm{ml}$ (Fig 1). There were no significant differences between the TNF levels in the five experimental groups before surgery. Surgical trauma in BDL mice resulted in a sharp increase in circulating TNF with average levels of circulating TNF of $3.5 \mathrm{ng} / \mathrm{ml}, 1.5$ hours after the operation (Fig 1). This was significantly different $(\mathrm{P}<0.01)$ from the sham operated mice which showed only a minor increase in circulating TNF. All anti-TNF treatments significantly reduced postoperative levels. TN3 was the most potent inhibitor. Pentoxifylline reduced the increase in circulating TNF, resulting in circulating TNF levels ranging from $180-1790 \mathrm{pg} / \mathrm{ml}$. Lactulose was less potent in inhibiting the increase in circulating TNF after the operation, leading to TNF levels ranging from $160-5600 \mathrm{pg} / \mathrm{ml}$.

\section{Figure 1: Serum TNF levels after RI in biliary} obstructed mice. Open bars represent TNF levels at day 17 after biliary obstruction, one day before the surgical trauma. Hatched bars represent TNF levels 90 minutes after surgical trauma. Data are expressed as means $\pm \mathrm{SD}$. $\mathrm{RI}=$ renal ischemia, $\mathrm{TN} 3=$ monoclonal antiTNF antibody, pentox = pentoxifylline and Duph $=$ Duphalac (lactulose). Data are expressed as means \pm SD. ${ }^{*}=p<0.05,{ }^{* *}=p<0.01$. $* * *=p<0.001$.

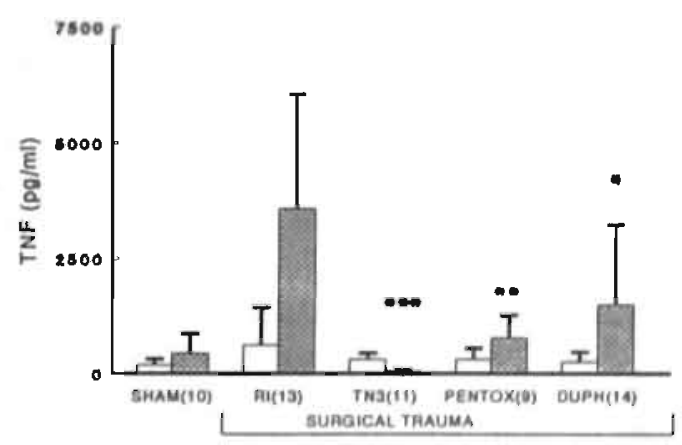

Table 2. Mortality after a bilateral renal ischemia in biliary obstructed mice."

\begin{tabular}{lcc}
\hline & MORTALITY & P-VALUE \\
\hline GROUP 1: SHAM-RI & $0 \%$ & $\mathrm{p}<0.01$ \\
GROUP 2: RI & $54 \%$ & - \\
GROUP 3: TN3-RI & $36 \%$ & $\mathrm{NS}$ \\
GROUP 4: PENTOX-RI & $44 \%$ & NS \\
GROUP 5: DUPH-RI & $7 \%$ & $\mathrm{p}<0.01$ \\
\hline
\end{tabular}

\footnotetext{
"Mortality was recorded during 120 hours. Levels of significance for differences in mortality between treatment groups compared with the non treated. RI group were determined by the log rank test (NS $=$ not significant $)$.
} 
Mortality after surgical trauma in BDL mice. Bilateral RI resulted in a mortality of $54 \%$ in Group 2 (Table 2). No mortality was observed after sham operation $(p<0.01$ ). Despite the fact that pretreatment with TN3 resulted in significantly reduced TNF levels this did not lead to a significantly reduced mortality ( $36 \%$; $p=0.48)$. Pretreatment with pentoxifylline was not effective in reducing mortality $(44 \% ; p=0.79)$ but pretreatment with lactulose resulted in significantly reduced mortality $(7 \% ; \mathrm{p}<0.01$ compared to the non treated group).

\section{Discussion}

TNF is known to play a pathogenetic role in several diseases like septic shock, transplant rejection and gastrointestinal diseases (34-39). Serum TNF levels were reported to be positively correlated with the fatal outcome in septic patients $(34,35)$. Moreover, experiments of Tracey et al. indicate that inhibition of TNF production by anti-TNF antibodies can prevent such endotoxin-induced mortality in animals (40). In contrast to these data, endogenous TNF has been shown to be involved in the immune process responsible for recovery from experimental peritonitis, indicating important physiologic functions for TNF (41). TNF is also suggested to play a role in the pathogenesis of the complications seen after surgery in jaundiced patients (20). Recently it was shown that in mice with experimental BDL TNF was circulating (27). Here we show that RI in jaundiced mice results in a high mortality (54\%) and increased levels of circulating TNF. Since TNF is suggested to play a central role in the observed mortality, we investigated the effects of different anti-TNF treatments. While TN3 and pentoxifylline are specific anti-TNF agents, lactulose has, besides its reduction of the endotoxin induced TNF production by monocytes $(20,30)$ various other effects attributable to its anti-endotoxin properties $(17,42)$. Anti-TNF treatment led to significant reduction of postoperative levels of circulating TNF. Although TN 3 was the most potent inhibitor, TN3 treatment did not lead to a significant reduced mortality $(36 \%)$. The same holds for treatment with pentoxifylline, which resulted in a mortality of $44 \%$. The failure of TN3 and pentoxifylline treatment is most likely not due to bacteraemia, since several reports describe the presence of systemic endotoxemia without bacteraemia in the presence of severe hepatic damage $(43,44)$; moreover, in a study of Katz et al. was shown that BDL did not affect bacterial clearance from the circulation (45). Only lactulose treatment resulted in a significant reduced mortality of $7 \%$, although it was less potent in reducing circulating TNF.

The positive effect of lactulose on mortality after surgery in BDL mice is in accordance with previous reports, which showed that lactulose prevented endotoxin related complications in jaundiced patients (17) and reduced mortality after surgery in jaundiced rats (20). In some studies this effect has been subscribed to the fact that lactulose inactivates endotoxin as measured by the LAL assay $(17,42)$. However, our group did 
not observe this inactivation, but reported that lactulose inhibits the production of TNF by monocytes in response to endotoxin (30).

The mechanism by which lactulose results in reduced mortality remains to be elucidated. It is of importance to realize that lactulose is administered orally and is present in the intestinal lumen, which is the most important source for endotoxins $(13,17,20,46)$. Under normal conditions, only very limited translocation of bacteria and leakage of these endotoxins occurs $(13,17,47)$. In situations of mucosal damage, stress, inflammation or BDL however, intestinal permeability is increased $(2,15,17,46)$. Lactulose was suggested to have a beneficial effect on leakage of these endotoxins into the circulation (17,48-50). This effect is supported by reports showing that endotoxemia is reduced by administration of lactulose $(17,42)$.

Recently it has been shown that the gut is potentially a source of inflammatory products; in patients with active ulcerative colitis, large amounts of TNF were observed in the faeces, whereas in the circulation only very little TNF is present $(37,51)$. If endotoxins and cytokines produced in the bowel are playing a role in the observed mortality, the presence of lactulose in the gut may explain the difference in effectivity. In summary, the experiments show that RI in mice with biliary obstruction is associated with high levels of circulating TNF and a high mortality. Of the anti-TNF treatments used, only lactulose results in a reduced mortality, next to the reduction of circulating TNF. This indicates that circulating TNF is not the ultimate factor in the mortality observed in these mice. Further studies are needed to confirm the presence of cytokines in jaundiced patients and to elucidate the pathophysiology of the mortality after surgery. 


\section{References}

1. Wait, R.B., K.U. Kahng. Renal failure complicating obstructive jaundice. Am. J. Surg. 1989:157:256-263.

2: $\quad$ Cahill, C.J., J.A. Pain, M.E. Bailey. Bile salts, endotoxin and renal function in obstructive jaundice, Surg. Gynaecol. Obstet, 1987;165:519-522.

3. Pitt, H.A., J.L. Cameron, R.G. Postier, T.R. Gadacz. Factors affecting mortality in biliary tract surgery. Am. J. Surg, 1981;141:66-72.

4. Neal, G., B. Lewis, B. Weaver, D. Panveliwalla. Senum bile acids in liver disease. Gut 1971:12:145-152.

5. Greve, J.W., D.J. Gouma, P.B. Soeters, W.A. Buurman. Suppression of cellular immunity in obstructive jaundice is caused by endotoxins: A study with germ-free rats. Gastroenterology 1990,98:478-485.

6. Pinto, M., A. Kaplun. Immune status in mice with experimental biliary obstruction. Clin. Immunol. Immunopathol. 1980;16:396-405.

7. Roughneen, P.T., D.J. Gouma, A.D. Kulkarni, W.F. Fanslow, B.J. Rowlands. Impaired specific cell-mediated immunity in experimental biliary obstruction and its reversibility by internal biliary drainage. J. Surg. Res. 1986;41:113-125.

8. Pain, J.A. Reticulo-endothelial function in obstructive jaundice. Br. J. Surg. 1987;74:10911094.

9. Holman, J.M., L.F. Rikkers. Biliary obstruction and host defense failure. J. Surg. Res. 1982:32:208-213.

10. Gouma, D.J., P.T. Roughneen, S. Kumar, F.G. Moody, B.J. Rowlands. Changes in nutritional status associated with obstructive jaundice and biliary drainage in rats. Am. J. Clin. Nutr. $1986 ; 44: 362-369$.

11. Buzby, G.B., J.L. Mullen, D.C. Mattews, C.L. Hobbs, E.F. Rosato. Prognostic nutritional index in gastrointestinal surgery. Am. J. Surg. 1980;139:160-167.

12. Wardle, R.B., N.A. Wright. Endotoxin and acute renal failure associated with obstructive. jaundice. Br. Med. J. 1970;4:472-474.

13. Deventer, v S.J.H., J.W. ten Cate, G.N.J. Tytgat. Intestinal endotoxemia. Gastroenterology 1988;94:825-831.

14. Wilkinson, S.P., H. Moody, J.D. Stamatakis, V.V. Kakkar, R. Williams. Endotoxemia and renal failure in cirrhosis and obstructive jaundice. Br. Med. J. 1976;2:1415-1418.

15. Bailey, M.E. Endotoxin, bile salts and renal function in obstructive jaundice. Br. J. Surg. 1976;63:774-778.

16. Gubem, J.M., J.J. Sancho, J. Simo, A. Sitges-serra. A randomized trial on the effect. of mannitol on postoperative renal function in patients with obstructive jaundice. Surgery 1988;103:39-44.

17. Pain, J.A., M.E. Bailey. Experimental and clinical study of lactulose in obstructive jaundice. Br. J. Surg. 1986;73:775-778.

18. Evans, H.J.R., V. Torrealba, C. Hudd, M. Knight. The effect of preoperative bile salt administration on postoperative renal function in patients with obstructive jaundice. $\mathrm{Br}$. J. Surg. 1982,69:706-708.

19. Dawson, J.L. Postoperative renal function in obstructive jaundice: effect of a mannitol diuresis. Br. Med. I. 1965;1:82-86.

20. Greve, J.W., J.G. Maessen, T. Tiebosch, W.A. Buurman, D.J. Gouma. Prevention of postoperative complications in jaundiced rats. Ann. Surg. 1991;212:221-227. 
21. Gouma, DJ., J.C.U. Coelho, J.D. Fisher, J.F. Schlegel, Y.F. Li, F.G. Moody. Endotoxemia after relief of biliary obstruction by internal and extemal drainage in rats. Am. J. Surg. 1986:151:476-479.

22. Greve, J.W., D.J. Gouma, W.A. Buurman. Bile acids inhibit endotoxin induced tumor necrosis factor production by monocytes. An in vitro study. Gut 1990;31:198-203.

23. Hunt, D.R., M.E.M. Allison, C.R.M. Prentice, L.H. Blumgart. Endotoxemia, disturbance of coagulation, and obstructive jaundice. Am. J. Surg. 1982;144;325-329.

24. Gouma, D.J., J.C.U. Coelho, J.F. Schlegel, Y.F. Li, F.G. Moody. The effect of preoperative internal and external biliary drainage on mortality of jaundiced rats. Arch. Surg. 1987;122: 731-734.

25. Pain, J.A., C.J. Cahill, M.E. Bailey. Perioperative complications in obstructive jaundice : therapeutic considerations. Br. J. Surg. 1985;72:942-945.

26. Beutler, B., A. Cerami. Cachectin: more than a tumor necrosis factor. N. Engl. J. Med. 1987:316:379-385.

27. Bemelmans, M.H.A., J.W. Greve, D.J. Gouma, W.A. Buurman. Cytokines Tumor Necrosis Factor and Interleukin-6 in experimental biliary obstruction in mice. Hepatology 1992;15: $1132-1136$.

28. Zabel, P., D.T. Wolter, M.M. Schönharting, U.F. Schade. Oxpentifylline in endotoxemia. Lancet $1989 ; i: 1474-1477$.

29. Waage, A., M. Sorensen, B. Stordal. Differential effect of oxpentifylline on tumour necrosis factor and interleukin-6 production. Lancet 1990:335:543.

30. Greve, J.W.. D.J. Gouma, P.A.M. van Leeuwen "W.A. Butrman. Lactulose inhibits endotoxin induced tumour necrosis factor production by monocytes. An in vitro study. Hepatology 1989:10:454-458.

31. Sheehan, K.C.F., N.H. Ruddle, R.D. Schreiber. Generation and characterization of hamster monoclonal antibodies that neutralizes Murine Tumor Necrosis Factors. J. Immunol. 1989; 142:3884-3893.

32. Dentener, M.A., J.W. Greve, J.G. Maessen, W.A. Buurman. Role of tumor necrosis factor in the phenomenon of the enhanced sensitivity of animals to endotoxin after exposure to iead. Immunopharm. Immunot. 1989:11:321-324.

33. Norusis, M.J. ed. SPSS/PC+ V3.1 BASE MANUAL for the IBM PC/XT/AT and PS/2. SPSS Inc., Chicago, USA.

34. Waage, A., A. Halstensen, T. Espevik. Association between tumor necrosis factor in serum and fatal outcome in patients with meningococcal disease. Lancet 1987:355-357.

35. Calandra, T., J.D. Baumgartner, G.E. Grau, M.M. Wu, P.H. Lambert, J.J. Schellekens JJ, J. Verhoef, M.P. Glauser, Swiss-Dutch J5 immunoglobin study group. Prognostic values of tumor necrosis factor/cachectin, interleukin-1, interferon- $\alpha$ in the senum of patients with septic shock. J. Inf. Dis. 1990;161:983-987.

36. Yoshioka, K., S. Kakumu, M. Arao, Y. Tșușumi, M. Inoue. Tumor Necrosis Factor $\alpha$ production by peripheral blood mononuclear cells of patients with chronic liver disease. Hepatology 1989:10:769-773.

37. Murch, S.H., V.A. Lamkin, M.O. Savage, J.A. Walker-Smith, T.T. MacDonald. Serum concentrations of tumour necrosis factoor $\alpha$ in childhood chronic inflammatory bowel disease. Gut 1991:32:913-917.

38. Jones, A., P.J. Selby, S. Hobbs, M.E. Gore, T.J. McElwain. Tumour necrosis factor, cholestatic jaundice and chronic liver disease. Gut 1990;31:938-939.

39. Imagawa, D.K., J.M. Millis, P. Seu, K.M. Olthof, J. Hart, E. Wasef, R.A. Dempsey, S. Stephens, R.W. Busuttil. The role of tumor necrosis factor in allograft rejection. Transplantation 1991;51:57-62. 
40. Tracey, K.J., Y. Fong, D.G. Hesse, K.R. Manogue, A.T. Lee, G.C. Kuo, S.F. Lowri, A. Cerami. Anti-endotoxin/TNF monoclonal antibodies prevent septic shock during lethal bacteriaemia. Nature 1987;330:662-664.

41. Echtenacher, B., W. Falk, D.N. Mannel, P.H. Krammer. Requirement of endogenous Tumor Necrosis Factor/Cachectin for recovery from experimental peritonitis. J. Immunol. 1990;145: 3762-3766.

42. Liehr, H., G. Englisch, U. Rasenack. Lactulose-A drug with antiendotoxin effect. Hepatogastroenterology 1980;27:356-360.

43. Cooperstock, M.S., R.P. Tucker, J.V. Baublis. Possible pathogenetic role of endotoxin in Reye's syndrome. Lancet 1975;1272-1273'.

44. Wilkinson "S.P., V. Arroyo, B.G. Gazzard, H. Moodie, R. Williams. Relation of renal impairment and hemorrhagic diathesis to endotoxemia in fulminant hepatic failure. Lancet 1974:1:521.

45. Katz, S., J.L. Grosfeld, K. Gross, D.A. Plager, D. Ross, R.S. Rosenthal, M. Hull, T.R. Weber. Impaired bacterial clearance and trapping in obstructive jaundice. Ann. Surg. 1984:199:14-20.

46. Nolan, J.P. Intestinal endotoxins as mediators of hepatic injury. An idea whose time has come again (Editorial). Hepatology 1989;10:887-889.

47. Delhunty, T., D. Hollander. A comparison of intestinal permeability between humans and three common laboratory animals. Comp. Biochem. Physiol. 1987;86A:565-567.

48. Nathavitharana, K.A., D.R. Lloyd, F. Raafat, G.A. Brown, A.S. McNeish. Urinary mannitol:lactulose excretion ratios and jejunal mucosal structure. Arch. Dis. Child. 1988,63:10541059.

49. Turner, M.W., P. Boulton, J.G. Shields, S. Strobel, S. Gibson, H.R.P. Miller, R.J. Levinsky. Intestinal hypersensitivity reactions in the rat $\mathrm{L}$. Uptake of intact protein, permeability to sugars and their correlation with mucosal mast-cell activation. Immunology 1988;63:119-124.

50. Ziegler, T.R., R.J. Smith, S.T. O'Dwyer, R.H. Demling, D.W. Wilmore. Increased intestinal permeability associated with infection in burn patients. Arch. Surg. 1988;123:1313-1319.

51. Braegger, C.P., S. Nichols, S.H. Murch, S. Stephens, T.T. Macdonald. Tumour necrosis factor alpha in stool as a marker of intestinal inflammation. Lancet 1992;339:89-91. 


\section{Chapter 5}

\section{INCREASED LEVELS OF TNF AND SOLUBLE TNF RECEPTORS IN BILIARY OBSTRUCTION IN MICE; SOLUBLE TNF RECEPTORS AS PROGNOSTIC FACTORS FOR MORTALITY}

M.H.A. Bemelmans, J.W. Greve, D.J. Gouma, W.A. Buurman. Submitted 


\section{Abstract}

Systemic TNF, an indicator of inflammatory responses, is present in mice with biliary obstruction. Two soluble TNF receptors, sTNFR-P55 and STNFR-P75, which are present in the circulation of healthy individuals are reported to play an essential role in the natural defense against TNF. Here we have investigated the properties of circulating TNF in jaundiced mice. The data show that TNF in these mice is biologically inactive, which prompted us to investigate the presence of sTNFR-P55 and sTNFR-P75 in such mice. The data reveal that in mice with obstructive jaundice an increase of both soluble TNF receptors is observed $(\mathrm{P}<0.001)$.

Surgical trauma in mice with obstructive jaundice is known to be accompanied by a high mortality (36\%) and enhanced TNF levels. Here we report that both systemic TNF and soluble TNF receptor levels are substantially enhanced after a surgical trauma in biliary obstructed mice and that soluble TNF receptor levels rather than TNF levels were found to be correlated with mortality. In line with this observation we demonstrate that pretreatment with oral lactulose before a surgical trauma in these mice, which was earlier shown to reduce mortality, significantly reduces postoperative levels of sTNFR-P75 $(p<0.005)$ and mortality $(0 \% ; \mathrm{P}<0.05)$ without reducing TNF levels, while anti-TNF antibodies had no effect on sTNF receptor levels and mortality.

In conclusion, our data suggest that TNF in biliary obstruction is rapidly inactivated by increased levels of soluble TNF receptors. Furthermore, soluble TNF receptor levels rather than TNF levels show a good correlation with mortality after surgery in obstructive jaundice. The positive effect of lactulose on mortality could be due to a decreased inflammatory status as reflected by reduced sTNFR-P75 levels.

\section{Introduction}

Endotoxemia is reported to be present iñ biliary obstruction in man as well as in animals $(1,2)$. Moreover, TNF, an indicator of an ongoing inflammatory process, is present in the circulation of biliary obstructed mice (3). It was shown that surgery in biliary obstructed mice resulted in an increase in circulating TNF and in a high mortality (4). Various anti-TNF treatments such as an anti-TNF mAb and lactulose, an agent which reduces TNF release by macrophages in vitro (5), have been tested. Preoperative oral lactulose syrup was the only agent which reduced the mortality after surgery in these mice by a still unresolved mechanism, this in contrast to preoperative anti-TNF treatment. These data suggested that blocking circulating TNF, using antiTNF mAbs is not crucial in preventing the observed mortality (4). This is in contrast to the effect of anti-TNF mAb's in septic models where anti-TNF treatment was shown to be highly effective (6). The fact that systemic anti-TNF treatment fails in the obstructive jaundice model, does not exclude an important role for TNF, since TNF levels at cellular level may be not sufficiently affected. Moreover, the fact that endotoxin, a strong inducer of TNF, plays an important role not only in obstructive jaundice 
(7) but also in other diseases (8,9), supports the hypothesis that TNF is of major importance in the pathophysiology of these diseases.

More recently it has been reported that TNF can circulate in a bioactive form and an inactive form (10). The latter is immunologically detectable and consists most likely of complexes of TNF bound to TNF binding proteins, which represent most likely soluble TNF receptors (sTNFR)(11). There are two TNFR, the $55 \mathrm{kD}$ TNF receptor (TNFR-P55) and the $75 \mathrm{kD}$ receptor (TNFR-P75) (12-14). The extracellular parts of both TNFR are present as soluble TNF receptors (sTNFR) in the circulation and are released from the cell membrane in several inflammatory situations (15-17) and experimental endotoxemia in man as well as in mice $(16,17)$. On the one hand, liberation of TNFR from the cell surface can protect for the deleterious effects of TNF by binding circulating TNF and forming biologically inactive TNF-sTNFR complexes which are cleared by the kidney (11) whereas on the other hand, the loss of cell surface receptors could lead to a transiently decreased responsiveness of cells to TNF (18). In those circumstances sTNFR could be regarded as TNF antagonists. Endotoxin is a strong inducer of liberation of sTNFR (17) and high sTNFR levels are considered to be an indicator for on ongoing inflammatory response. However, also TNF increases levels of sTNFR and sTNFR levels are considered to be important parameters for the status of inflammatory diseases $(19,20)$.

To investigate the inflammatory response in obstructive jaundice, we studied the role of TNF and sTNFR in obstructive jaundice. Moreover, since surgery in obstructive jaundice was associated with a high mortality and lactulose was shown to reduce LPS induced TNF release in vitro and to reduce endotoxemia and survival in vivo $(1,4,7)$, we investigated whether lactulose treatment (a powerful TNF inhibitor) affected sTNFR levels.

\section{Materials and methods}

Animals. Female Swiss mice weighing 27.5-34.5 grams were obtained from Charles River Breeding Laboratories (Heidelberg, FRG). The mice were maintained on a standard laboratory diet and were allowed free access to water. University of Limburg criteria for animal care and use of laboratory animals in research were followed throughout. The experiments were approved by the ethical committee for animal care of the University of Limburg.

Reagents. Bovine Serum Albımin (BSA), 3-[4,5-dimethylthiazol-2-yl]-2,5 diphenyltetrazolium bromide (MTT), and $\mathrm{N}, \mathrm{N}$-dimethyl formamide (DMF) were obtained from Sigma (St. Louis, MO); 3, 3',5, 5'- tetramethylbenzidine (TMB) was obtained from Kirkegaard \& Perry Laboratories Inc. (Gaithersburg, Maryland). TN3, a hamster monoclonal antibody specific for murine TNF was a generous gift from Celltech, Slough, UK (21). Sodium dodecyl sulfate (SDS) was obtained from Bio-Rad (Richmond, CA). Peroxidase conjugated goat anti rabbit IgG was obtained from Jackson 
(Westgrove, PA), Polyclonal rabbit anti-murine TNF antiserum (RAMT) was produced by injecting rabbits with murine TNF kindly provided by Knoll/BASF (Ludwigshafen, FRG). Recombinant murine TNFR-P55, TNFR-P75, rabbit anti soluble murine TNFRP55 and P75 were kindly provided by Dr. D.V. Goeddel (Genentech, San Francisco, CA). Lactulose syrup (Duphalac) was a kind gift from Duphar (Weesp, The Netherlands). Crystalline lactulose (Legendal) was obtained from Inpharzam (Amersfoort, The Netherlands).

Surgical procedures. Female Swiss mice were operated under light ether anesthesia. Surgery was performed on a temperature controlled watermattress.

Bile duct ligation (BDL): A $1.0 \mathrm{~cm}$ long mid-abdominal incision was made and the common bile duct was ligated and divided following our modification of the method described by Pinto $(3,22)$. The abdominal wall was closed in two layers. After the BDL all mice received $1 \mathrm{ml}$ saline subcutaneously. Blood was sampled on defined time points. Mice were sacrificed after 16 days.

Renal Ischemia (RI): RI was performed 14 days after BDL. On day 13, $100 \mu \mathrm{l}$ of blood was taken from every mouse. Mice were anesthetized with ether and a midline abdominal incision was made. The renal vessel pedicles were clamped during 30 minutes with soft tip vascular clamps to cause renal ischemia. During the ischemic period the abdomen was closed, ether anesthesia was interrupted and the animals were allowed to recover. In sham operated mice, renal vessels were dissected but not clamped. After 30 minutes of (sham) ischemia, the abdomen was opened again (also in the sham group) and clamps were removed. After macroscopic confirmation of the reperfusion, the abdomen was closed. Blood was obtained by puncture of the retrobulbar venous plexus after $90 \mathrm{~min}$.

\section{Experimental protocol}

$B D L:$ Mice were randomized into two groups, a BDL group $(\mathrm{n}=9)$ and a sham operated group $(\mathrm{SH} ; \mathrm{n}=8)$. Blood was sampled the day before the operation and on day $4,8,12$, and day 16. TNF was measured by elisa and bioassay and STNFR were measured by elisa. Renal function was assessed by serum urea measurements and biliary obstruction was confirmed by bilirubin measurements. Renal blood flow measurements using paraaminohippuric acid were done in a separate group of mice.

$R I$ : Mice underwent a BDL or sham operation. BDL mice were randomized into 4 experimental groups: Group 1. BDL mice receiving from day $11-14$ twice daily $0.3 \mathrm{ml}$ distilled water orally (by gavage) followed by RI at day 14 (BDL-RI); Group 2. BDL mice receiving from day $11-14$ twice daily $0.2 \mathrm{ml} 30 \%$ lactulose syrup orally followed by RI at day 14 (BDL-Syr); Group 3. BDL mice receiving from day 11-14 twice daily $0.2 \mathrm{ml}$ crystalline lactulose $(200 \mathrm{mg} / \mathrm{ml})$ orally followed by RI at day 14 (BDL-Crys); Group 4. BDL mice receiving $0.5 \mathrm{mg}$ of the monoclonal anti-TNF antibody (TN3) ip dissolved in $0.5 \mathrm{ml}$ saline 7 hours before the operation (BDL-TN3). The antibody was administered 7 hours before RI because previous data in acute septic models showed a high efficacy when given at that time point (21). A control group of 7 mice receiving 
$0.5 \mathrm{ml}$ saline ip 7 hours before the operation was used as a control group for group 4 . However, because the results after RI were not different from control group 1, which received fluid orally, these data were for clarity purposes not shown.

The two different lactulose preparations were used since in vitro experiments showed that lactulose syrup is a more powerful TNF inhibitor than crystalline lactulose (5), Preliminary data reveal that the difference is possibly due to differences in purification processes. The presence of 3-Deoxy-D-Glyceropentulose (3-DGP) in lactulose could play a role in this phenomenon. Moreover, 3-DGP is reported to be a biological antiinflammatory agent (23). Blood for TNF and sTNFR measurements was collected 90 $\min$ and 24 hours after RI after which the mice were exsanguinated. During these 24 hours mortality was monitored. Animals with leakage of bile or animals which did not survive the first $90 \mathrm{~min}$. after reperfusion were excluded from the experiment. After correction for mortality during $\mathbf{R I}$, the remaining animals were divided as follows over the groups: group 1: $n=14$, group $2: n=11$, group $3: n=11$, group $4: n=11$; sham operated group 5: $\mathrm{n}=9$ (Table 1).

Table 1. Experimental Design *

\begin{tabular}{llllll}
\hline & $\begin{array}{l}\text { Group 1 } \\
\text { RI } \\
(\mathrm{n}=14)\end{array}$ & $\begin{array}{l}\text { Group 2 } \\
\text { Syr } \\
(\mathrm{n}=11)\end{array}$ & $\begin{array}{l}\text { Group 3 } \\
\text { Crys. } \\
(\mathrm{n}=11)\end{array}$ & $\begin{array}{l}\text { Group 4 } \\
\text { TN3 } \\
(\mathrm{n}=11)\end{array}$ & $\begin{array}{l}\text { Group 5 } \\
\text { Sham-RI } \\
(\mathrm{n}=9)\end{array}$ \\
\hline Day 0 & BDL & BDL & BDL & BDL & Sham BDL \\
Day 11 & PBS & Syr & Crys & - & PBS \\
Day 12 & PBS & Syr & Crys & - & PBS \\
Day 13 & PBS & Syr & Crys & - & PBS \\
Day 14 & RI & RI & RI & TN3.RI & RI \\
\hline
\end{tabular}

- $\mathrm{BDL}=$ bile duct ligation, $\mathrm{RI}=$ renal ischemia, $\mathrm{TN} 3=$ monoclonal anti-TNF antibody, Crys= crystalline lactulose, Syr= lactulose syrup. Serum TNF and sTNFR were measured by ELISA 90 minutes after reperfusion. Survival was assessed during 24 hours.

Enzyme linked immunosorbent assay (ELISA) for murine TNF: ELISA for murine TNF was performed as described earlier by Dentener (24). In short: A 96-well immuno maxisorp plate (Nunc, Roskilde, Denmark) was coated with TN3. Aspecific binding was blocked with BSA. After washings, $100 \mu \mathrm{l}$ diluted serum sample $(50 \mu \mathrm{l}$ serum/ 50 $\mu$ PBS) was added to each well. A standard titration curve was obtained by making a serial dilution of a known sample of murine recombinant TNF in nomal murine serum. Subsequently, plates were washed and incubated with a polyclonal rabbit anti- 
murine TNF antiserum followed by a peroxidase conjugated goat anti rabbit IgG and substrate TMB, activated with $\mathrm{H}_{2} \mathrm{O}_{2}$. The reaction was stopped and optical density was read. The ELISA has a lower detection limit of $50 \mathrm{pg} / \mathrm{ml}$ TNF. The ELISA recognizes free TNF as well as TNF bound to binding proteins (immunologically detectable TNF).

WEHI 164 cytotoxicity bioassay. Biological TNF activity was measured using the murine fibrosarcoma WEHI 164 cell line $(25,26)$. The MTT-method was used to assess cell killing as described previously (27). A standard titration curve was obtained by making a serial dilution of a known quantity of a murine rTNF sample. The dilution giving rise to $50 \%$ lysis was correlated to the $\mathrm{LD}_{50}$ of the standard curve. $\mathrm{LD}_{50}$ ranged between 10 and $40 \mathrm{pg} / \mathrm{ml}$.

Enzyme linked immunosorbent assay for soluble murine TNF-Receptors. ELISA for murine sTNFR was performed as described earlier (17). A 96 well immuno-maxisorp plate (Nunc, Roskilde, Denmark) was coated with rabbit anti-soluble murine TNFRP55 or rabbit anti-soluble murine TNFR-P75, resp. A standard titration curve was obtained by making a serial dilution of a known sample of recombinant murine TNFRP55 or TNFR-P75, resp. Subsequently, plates were washed and incubated with biotinylated polyclonal rabbit anti-soluble mTNFR-P55 or anti-soluble mTNFR-P75. After washings, plates were incubated with streptavidin peroxidase followed by enzyme reaction. The detection limit for murine sTNFR-P55 is $5 \mathrm{pg} / \mathrm{ml}$ and for murine sTNFRP75 $50 \mathrm{pg} / \mathrm{ml}$.

Renal blood flow (RBF) measurements. RBF was assessed by modification of the method of Selkurt et al (28). In stead of administration of para-aminohippuric acid ( $\mathrm{PAH})$ by catheters we administered PAH by means of osmotic minipumps implanted intraperitoneally. To this end, $6 \mathrm{BDL}$ operations and 4 sham operations were performed. Fourteen days aftei surgery, Osmotic Alzet minipumps (model 1003D), Alza corporation Palo Alto, CA) were implanted ip. Before surgery, the pumps were filled with $100 \mu \mathrm{l}$ of $2.1 \mathrm{M}$ PAH. After filling, they were incubated for 4 hours at $37 \mathrm{C}$ in sterile saline in order to obtain stable flow. Thereafter, the pumps were implanted ip. Blood was sampled 18,28 and 52 hours after implantation. Blood was taken by orbital puncture and collected on ice in heparinized cups (Microvette CB1000, Sarstedt, Numbrecht, FRG). For PAH determinations, $100 \mu \mathrm{l}$ of whole blood was deproteinized with $100 \mu \mathrm{l}$ of $50 \%$ trichloracetic acid, thoroughly mixed, allowed to stand for deproteinization $\left(4^{\circ} \mathrm{C}, 30\right.$ minutes) and centrifuged after which the supernatant was stored at $-70^{\circ} \mathrm{C}$. PAH was determined by standard techniques as described previously (29). PAH extraction rate is considered to be more than $90 \%$ (30). Therefore, RBF was calculated as input divided by the whole blood concentration of PAH in $\mathrm{ml} / \mathrm{min}$ (30).

Statistical analysis: Statistics were performed using the SPSS/PC+ Statistical Software Package (31). Differences in serum TNF and sTNFR levels were calculated using analysis of variance. Differences between TNF or STNFR levels preoperatively or 
postoperatively and mortality were determined using the Kruskall Wallis Test. Differences in mortality were calculated by the Log-Rank test. Data are expressed as means \pm SEM unless stated otherwise. Probability values below 0.05 were considered to be statistically significant.

\section{Results}

Confirmation of jaundice and evaluation of renal function. Bilirubin levels in biliary obstructed mice, taken 16 days after the BDL were significantly higher compared to the sham operated control mice $(277 \pm 82 \mu \mathrm{mol} / \mathrm{l}$ vs $3.7 \pm 0.8 \mu \mathrm{mol} / \mathrm{l}$, resp; $\mathrm{p}<0.001)$, indicating that the operation had been successful. Since biliary obstruction was suggested to be accompanied by an altered renal function (32-34) and because TNF and sTNFR levels are affected by decreased renal function (11), we studied urea levels as well as renal blood flow (RBF). Urea measurements 16 days after BDL revealed no significant differences between the BDL $(n=9)$ and the sham $(n=8)$ mice $(8.3 \pm 5.4$ vs $9.1 \pm 1.3 \mathrm{mmol} / \mathrm{l} ; \mathrm{NS}$ ).

The implantation of the osmotic minipump in BDL mice for RBF measurement resulted in a reduced RBF 18 hours after implantation compared to control mice as shown in Table 2. The data reveal that the RBF in BDL mice is only transiently reduced and the results suggest that this reduction is most likely due to surgery. After surgery, the RBF gradually improves resulting in comparable RBF after 52 hours between BDL and control mice. The results of the urea levels and the RBF data in $\mathrm{BDL}$ mice suggest that renal function is not or negligibly affected in BDL. mice.

Table 2. Renal blood flow $(\mathrm{ml} / \mathrm{min})$ after bile duct ligation. (BDL) or Sham operation.

\begin{tabular}{llll} 
& $18 \mathrm{hr}^{\prime \prime}$ & $28 \mathrm{hr}$ & $52 \mathrm{hr}$ \\
\hline Sham $(\mathrm{n}=4)$ & $2.55 \pm 0.18^{ \pm}$ & $3.41 \pm 0.85$ & $2.25 \pm 0.51$ \\
BDL $(\mathrm{n}=6)$ & $1.37 \pm 0.31$ & $1.85 \pm 0.49$ & $2.30 \pm 0.24$ \\
\hline
\end{tabular}

Time point after implantation of osmotic mini-pump.

" Data are expressed as means \pm SEM.

Circulating TNF and kinetics of sTNFR after BDL:

Circulating TNF levels measured by ELISA before operation were below detection limit. After sham BDL operation, TNF levels remained undetectable during the experimental procedure. In the BDL group however, there was a ciear increase in circulating TNF that became evident after 8 days, reaching peak levels after 16 days ( $p<0.001$; Fig. 1). However, in none of the samples biologically active TNF could be 
detected by the WEHI-bioassay, suggesting that TNF circulates as biologically inactive TNF-sTNFR complexes (Fig. 1).

Figure 1: TNF levels in BDL and sham operated mice. Solid line represents serum TNF levels in BDL (closed circles; $n=9$ ) and sham operated mice (open circles; $n=8$ ) during 16 days, as measured by ELISA. Dashed line represents TNF levels as determined by WEHI assay. Data are expressed as means \pm SEM.

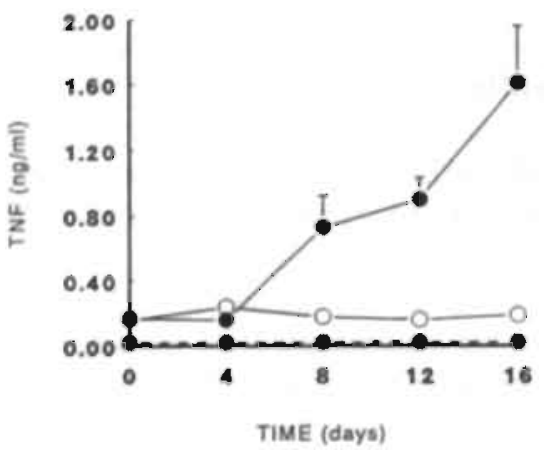

Whereas TNF is not detectable in serum of normal non-treated mice, we detected approximately $90 \mathrm{pg} / \mathrm{ml}$ sTNFR-P55 and $5.5 \mathrm{ng} / \mathrm{ml}$ sTNFR-P75 in normal control mice, levels which are in the same range as we reported previously (17). Sham BDL operation resulted in a negligible increase in STNFR-P75 levels, whereas sTNFR-P55 levels remained similar. Biliary obstruction however resulted in a rapid increase in both sTNFR-P55 levels and sTNFR-P75 levels. sTNFR-P55 levels showed peak levels of $400 \mathrm{pg} / \mathrm{ml}$ after $12-16$ days ( $<<0.01$ compared to sham operated controls; Fig. 2A), while sTNFR-P75 levels revealed peak levels after 12 days of $34 \mathrm{ng} / \mathrm{ml}(\mathrm{p}<0.01$ compared to the sham operated controls; Fig. 2B). These increased levels are strongly suggestive for an ongoing inflammatory process in these mice. In a previous study it was shown that endotoxin administration in combination with renal ischemia (RI) resulted in high TNF levels and high mortality, while either treatment separately was tolerated well in normal mice (35). In accordance with this study, RI in jaundiced mice, a situation which is known to be accompanied by endotoxemia results in a high mortality (4). Because endotoxemia is associated with high TNF and sTNFR levels and since these levels are related to mortality $(8,9,36)$, renal ischemia was used as a surgical trauma model in BDL mice.

Serum TNF and serum sTNFR after RI: TNF levels as determined by ELISA were below detection limit in the sham operated group and revealed a small increase up to $0.21 \mathrm{ng} / \mathrm{ml}$ after RI (data not shown). In the 4 experimental BDL groups, there were preoperatively no significant differences in serum TNF levels as measured by ELISA (Fig. 3). Serum samples taken $90 \mathrm{~min}$. after RI revealed that serum TNF levels were significantly increased in group 1 (BDL-RI group). As expected, TNF levels were significantly reduced in group 4 (anti-TNF group) compared to group 1, while they were not statistically different in group 2 (lactulose syrup group) and 3 (crystalline 
lactulose group) compared to group 1 (Fig. 3). Moreover, no significant differences were observed between serum TNF levels of BDL mice before RI from group 1-4 which were going to die compared with TNF levels of survivors $(p=0.91)$, nor was this difference present 90 minutes after RI $(p=0.54)$. In none of the animals the TNF as detected by ELISA was biologically active after RI (data not shown).

Figure 2: Serum sTNFR levels in BDL and sham operated mice. BDL mice are represented by closed circles $(n=9)$ and sham operated mice by open circles $(n=8)$ Serum sTNFR were monitored during 16 days. Upper graph A represents sTNFR-P55 levels and lower graph $B$ represents sTNFR-P75 levels. Data are expressed as means \pm SEM.

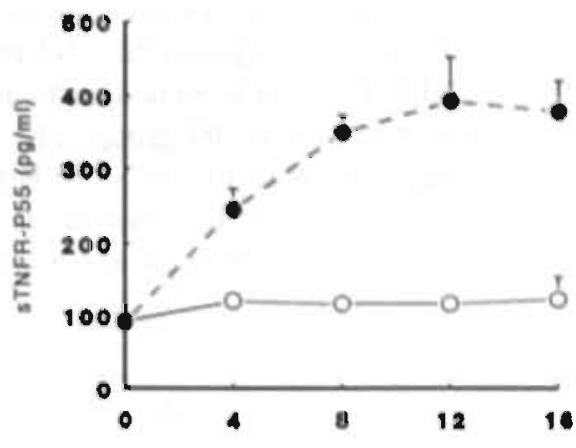

A

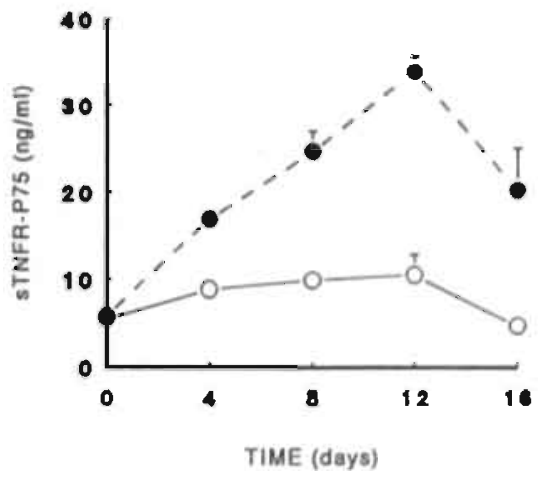

B

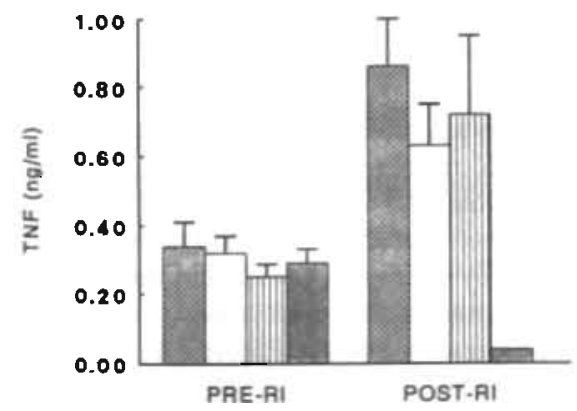

Figure 3: Serum. TNF level's before and $90 \mathrm{~min}$ after RI in BDL mice. Control mice (group 1) are represented by crosshatched bars $(n=14)$. lactulose syrup (group 2), treated BDL mice by open bars $(n=11)$, crystalline lactulose (group 3) treated BDL mice by vertically hatched bars $(n=11)$ and TN3 treated (group 4) BDL mice by hatched bars $(n=11)$, as measured by ELISA. Data are expressed as, means \pm SEM. 
In the four individual treatment groups (group 1-4), sTNFR-P55 levels and sTNFR-P75 levels were similarly increased preoperatively before RI (Fig. 4 A/B), while sTNFR levels in the sham group (group 5) were at the same level as normal control mice. After RI, a significant increase was observed of sTNFR-P55 levels and sTNFR-P75 levels in all experimental groups, although the increase in the sham group subjected to RI was much smaller compared to the BDL-RI group (Fig 4 A/B). There were no differences between sTNFR-P55 levels in the BDL-RI mice (group 1) and the treatment groups. However, while the increase in STNFR-P75 levels in the BDL-RI group, the crystalline lactulose group and the TN3 group were not significantly different form each other, sTNFR-P75 levels were significantly reduced in the lactulose syrup group $(p<0.005)$ compared to BDL-RI group. The fact that crystalline lactulose in contrast to lactulose syrup does lead to low sTNFR levels appears to be in line with in vitro results where the former is less potent in reducing LPS induced TNF release by monocytes than the latter, although in vivo TNF reduction is minimal.

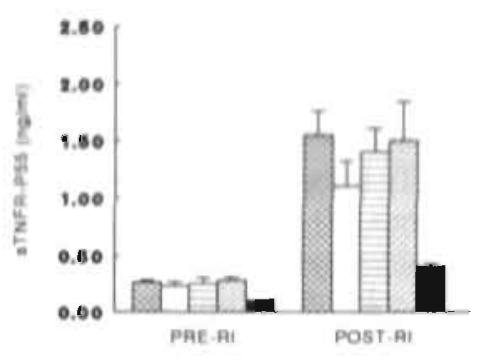

A

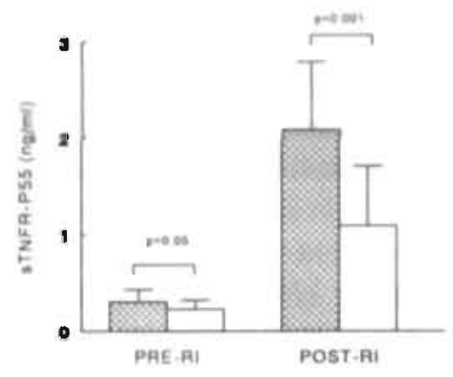

A

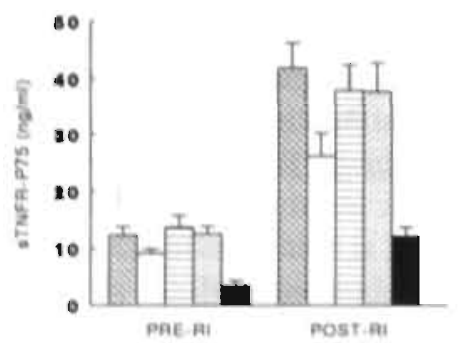

B

Fisure 4: Serum sTNFR levels before and 90 min after RI in BDL mice. Control mice (group I) are represented by crosshatched bars $(n=14)$, lactulose syrup (group 2) treated BDL mice by open bars $(n=11)$, crystalline lactulose (group 3) treated BDL mice by horizontally hatched bars $(n=11), T N 3$ treated (group 4) BDL mice by hatched bars $(n=11)$ and sham operated BDL mice by closed bars ( $n=9$ ). Upper graph A represents sTNFR-P55 levels, lower graph B represents sTNFR-P75 levels. Data are expressed as means \pm SEM.

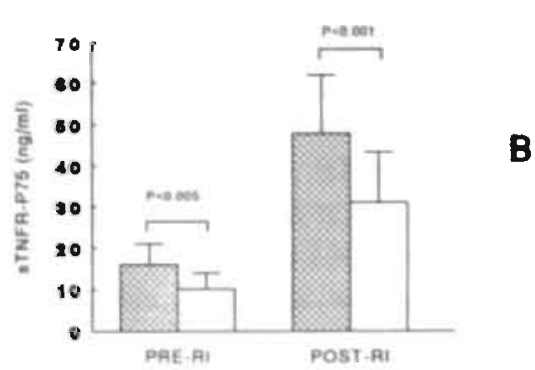

Figure 5: Serum sTNFR levels before and 90 min after $R I$ in all experimental $B D L$ mice (sham operated BDL mice excluded) in survivors and non survivors. The survivors are represented by open bars $(n=32)$ and non survivors by crosshatched bars $(n=15)$. Upper graph A represents sTNFR-P55 levels, lower graph B, represents sTNFR-P75 levels. Data are expressed as means \pm STD. 
Mortality: Mortality in the BDL-RI group was $36 \%$ (Table 3). Pretreatment with TN3 or crystalline lactulose did not reduce mortality (both $45 \%$ ). However, in agreement with previous published data, lactulose syrup significantly reduced mortality $(0 \%$; $\mathrm{p}<0.05$ ). Preoperatively, there was a significant difference between both sTNFR-P55 and sTNFR-P75 levels in mice of group 1-4 that survived RI compared to the mice of these groups that did not survive RI ( $p=0.035$ and $p<0.005$, resp.). This difference was also present $90 \mathrm{~min}$ after RI ( $<<0.001$ and $p<0.001$, resp; Fig. 5).

Table 3. Mortality after $\mathrm{RI}^{3}$.

\begin{tabular}{llcl} 
& & Mortality & P-value \\
\hline BDL/RI & $(5 / 14)$ & $36 \%$ & $=$ \\
TN3/RI & $(5 / 11)$ & $45 \%$ & NS \\
Lactulose syrup/RI & $(0 / 11)$ & $0 \%$ & $\mathrm{p}<0.05$ \\
Crystalline lactulose/RI & $(5 / 11)$ & $45 \%$ & NS \\
Sham BDL/RI & $(0 / 9)$ & $0 \%$ & $\mathrm{p}<0.05$ \\
\hline
\end{tabular}

$\mathrm{BDL}=$ Bile Duct Ligation; $\mathrm{RI}=$ Renal Ischemia; $\mathrm{TN} 3=$ monoclonal anti-TNF antibody .

"Mortality was recorded during 24 hours.

\section{Discussion}

The presence of the cytokine TNF in the circulation is considered to be indicative for the presence of an ongoing inflammatory response (37). However, also increased levels of circulating sTNFR, which are considered to be antagonists of TNE, are observed in the circulation during inflammation $(19,20)$. During experimental endotoxemia, sTNFR levels are strongly increased and remain, in contrast to systemic TNF, elevated for a longer period of time $(16,17,20)$. Therefore, sTNFR levels appear to be of value for monitoring the inflanmatory response. Since obstructive jaundice is associated with endotoxemia, we determined besides TNF also sTNFR in BDL mice. The data showed that in BDL mice both TNF and sTNFR levels (sTNFR-P55 as well as sTNFR-P75) are strongly enhanced, indicating an ongoing inflammatory process. These observations support previous data from our group showing the presence of systemic TNF and IL-6, indicative for an inflammatory process in BDL mice (3).

The fact that detected TNF in BDL mice is not biologically active probably indicates, taking into account the short half-life of TNF, the presence of an ongoing synthesis of TNF, after which the protein is rapidly inactivated in the circulation (10). We hypothesize that this inactivation is, at least partially, caused by formation of bio-inactive, immunologically detectable complexes of TNF with STNFR. Indeed, we observed in- 
creased levels of both sTNFR in the circulation of BDL mice. Nevertheless, while TNF levels seem to increase during the progression of obstructive jaundice, sTNFR levels seem to reach plateau levels and sTNFR-P75 even reveals a decrease after several days. Because bioactive TNF remains absent, these data suggest that even the diminished amount of sTNFR is capable of inactivating TNF. However, it is not sure whether STNFR are the only inhibitors of TNF.

Since TNF-sTNFR complexes are cleared by the kidney (11), it was essential to exclude that the observed increase in STNFR after BDL was due to diminished renal function. To this end we determined renal function by measuring serum urea and renal blood flow by PAH clearance in BDL mice. In contrast with several reports which describe a decreased renal function after biliary obstruction (32-34), but in agreement with others (38), we observed no significant differences in renal function in BDL mice, which could be held responsible for the massive increase in levels of circulating sTNFR. We conclude therefore that the increased levels of sTNFR after BDL reflect an ongoing inflammatory process rather than a decreased renal function. However, the data regarding the RBF reveal that surgery in BDL mice (implantation of the pumps) is associated with a temporary reduction in RBF. This appears to reflect the higher susceptibility of BDL mice to trauma.

Intervention with lactulose syrup was the only treatment which resulted in a significant reduced mortality while systemic TNF levels were not significantly reduced. This is in keeping with previous data which showed that TNF was of little prognostic importance for mortality $(4,39)$. In contrast, sTNFR levels were found to be strongly correlated with mortality after surgery in jaundiced mice.

The protective mechanism of lactulose syrup is thus far unclear. The significant reduction in sTNFR-P75 levels suggest that the effect of lactulose syrup on mortality is the result of reduction of the inflammatory status of the mice. Lactulose sytup could reduce the inflammatory status by its reported reduction of endotoxemia by inactivating endotoxins originating from the gut (1). However, also a direct effect of lactulose on cytokine production by mononuclear phagocytes could be responsible (5). The fact that crystalline lactulose is not as effective as lactulose syrup is in line with previous data showing that lactulose syrup is a more potent LPS inactivator (1) and reduced more effectively TNF production of mononuclear phagocytes after LPS stimulation (5). The difference in effect between lactulose syrup and crystalline lactulose is expected to result from differences in purification process of both lactulose preparations. The putative presence of 3-Deoxy-D-Glyceropentulose (a compound which is known for its antiproliferative and cytotoxic properties), could play a role in the observed differences (23). In pilot experiments with different lactulose contaminants, 3-DGP appeared to inhibit TNF release after injection of endotoxin in mice (data not shown).

As mentioned above, increased levels of sTNF- R are not only a result of an inflammatory response but are also influenced by renal function $(36,40)$. Recently, we observed that plasma levels of both sTNFR are affected to an identical extent by 
decreased renal function (data not shown). After RI, lactulose syrup affected only sTNFR-P75 levels, but not sTNFR-P55 levels. Due to the discrepancy between both sTNFR levels, it is concluded that the reduction of sTNFR-P75 levels after RI was more likely to be the result of the reduced inflammatory status, than that it was the result of a decreased clearance of the sTNFR by the kidneys. However, we can not exclude that the increased STNFR levels after RI are partially due to diminished renal function.

In conclusion, the presence of TNF in inactivated form together with enhanced levels of both STNFR in the circulation of mice with biliary obstruction is indicative for an ongoing inflammatory process. Further, the data show that sTNFR levels, in contrast to systemic TNF levels, correlate with mortality after a surgical trauma in jaundiced mice. Lactulose syrup treatment is associated with a positive effect on mortality and with a reduction of sTNFR-P75 levels, which suggests that the inflammatory response is reduced, although the underlying mechanism remains unclear. The clinical importance of increased sTNFR levels as an indicator for inflammation after surgery in obstructive jaundice remains to be elucidated. 


\section{References}

1. Pain, J.A., M.E. Bailey. Experimental and clinical study of lactulose in obstructive jaundice. Br. J. Surg. 1986; 73: 775-778.

2. Van Bossuyt, H., C. Desmaretz, G.B. Gaeta, E. Wisse. The role of bile acids in the development of endotoxemia during obstructive jaundice in the rat. J. Hepatol. 1990;10:274-279.

3. Bemelmans, M.H.A., J.W. Greve, D.J. Gouma, W.A. Buurman. Cytokines Tumor Necrosis Factor and Interleukin-6 in experimental biliary obstruction in mice. Hepatology 1992;15: $1132-1136$.

4. Bemelmans, M.H.A., D.J. Gouma, J.W. Greve, W.A. Buurman. The effect of anti-TNF treatment on circulating Tumor Necrosis Factor and mortality after surgery in jaundiced mice. Br. J. Surg. 1993;80:1055-1058.

5. Greve, J.W., D.J, Gouma, P.A.M. van Leeuwen, W.A. Buurman. Lactulose inhibits endotoxin induced tumour necrosis factor production by monocytes. An in vitro study. Hepatology $1989 ; 10: 454-458$.

6. Beutler, B., I.W. Milsark, A.C. Cerami. Passive immunization against Cachectin/Tumor Necrosis Factor protects mice from lethal effect of endotoxin. Science 1985:229:869-871.

7. Greve, J.W., J.G. Maessen, T. Tiebosch, W.A. Buurman, D.J. Gouma. Prevention of postoperative complications in jaundiced rats. Ann. Surg. 1991;212:22I-227.

8. Millar, A.B., M. Singer, A. Meager, N.M. Foley, N.Mc.I. Johnson, G.A.W. Rook. Tumour Necrosis Factor in bronchopulmonary secretions of patients with adult respiratory distress syndrome. Lancet 1989:712-714.

9. Waage, A., A. Halstensen, T. Espevik. Association between Tumour Necrosis Factor in serum and fatal outcome in patients with meningococcal disease. Lancet 1987;355-357.

10. Munck-Petersen, C., B.K. Møller. Immunological reactivity and bioactivity of tumour necrosis factor. Lancet 1988;i:934-935.

11. Bemelmans, M.H.A., D.J. Gouma, W.A. Buurman. Influence of nephrectomy on Tumor Necrosis Factor (TNF) clearance in a murine model. $J$. Immunol. 1993; 150:2007-2017.

12. Engelmann, H., H. Holtmann, C. Brakebush, Y.S. Avni, I. Sarov, Y. Nophar, E. Hadas et al. Antibodies to a soluble form of a tumor necrosis factor (TNF) receptor have TNF-like activity. J. Biol. Chem. 1990;265:14497-14504.

13. Engelmann, H., D. Novịck. D. Wallach. Two tumọ necrọsis factor-binding proteins purified from human urine: evidence for immunological cross-reactivity with cell surface tumor necrosis factor receptors. J. Biol. Chem. 1990;265:1531-1536.

14. Brockhaus, M., H.J. Schoenfeld, E.J. Schlaeger, W. Hunziker, W. Lesslauer, H. Loetscher. Identification of two types of tumor necrosis factor receptors on human cell lines by monoclonal antibodies. Proc. Natl. Acad. Sci. USA 1990;87:3127-3131.

15. Peetre, C., H. Thysell, A. Grubb, 1. Olsson. A tumor necrosis factor binding protein is present in human biological fluids. Eur. J. Haematol. 1988;41:414-419.

16. Spinas, G.A., U. Keller, M. Brockhaus. Release of soluble receptors for Tumor Necrosis Factor (TNF) in relation to circulating TNF during experimental endotoxemia. J. Clin. Invest. 1992:90:533-536.

17. Bemelmans, M.H.A., D.J. Gouma, W.A. Buurman. LPS induced sTNFR-Receptor release in vivo in a murine model: investigation of the role of TNF, IL-1, LIF, and IFN $\gamma$. J. Immunol. $1993 ; 151: 5554-5562$.

18. Aderka, D., H. Engelmann, Y. Maor, C. Brakebush, D. Wallach. Stabilization of the bioactivity of Tumor Necrosis Factor by its soluble receptors. J. Exp. Med. 1992;175:323-329. 
19. Cope, A.P., D. Aderka, M. Doherty, H. Engelmann, D. Gibbons, A.C. Jones, F.M. Brennan et al. Increased levels of soluble Tumor Necrosis Factor receptors in the sera and synovial fluid of patients with rheumatic diseases. Arthritis Rheum. 1992;35:1160-1169.

20. Van Zee, K.J., T. Kohno, E. Fischer, C.S. Rock, L.L. Moldawer, S.F. Lowry. Tumor Necrosis Factor soluble receptors circulate during experimental and clinical inflammation and can protect against excessive Tumor Necrosis Factor $\alpha$ in vitro and in vivo. Proc. Natl. Acad. Sci. $1992 ; 89: 4845-4849$.

21. Sheehan, K.C.F., N.H. Ruddle, R.D. Schreiber. Generation and characterisation of hamster monoclonal antibodies that neutralizes Murine Tumor Necrosis Factors. J. Immunol. 1989; 142: 3884-3893.

22. Pinto, M., A. Kaplun. Immune status in mice with experimental biliary obstruction. Clin. Immunol. Immunopathol. 1980;16:396-405.

23. Derwent Publications LTD. 1991. Europaische Patentanmeldung. Veroffentlichungsnummer: 0432309A1. Anmeldungsnummer: 89123301.7

24. Dentener, M.A., J.W. Greve, J.W. Maessen, W.A. Buurman. Role of tumor necrosis factor in the phenomenon of the enhanced sensitivity of animals to endotoxin after exposure to lead. Immunopharmacology and Immunotoxicology 1989;11: 321 -324.

25. Rollinghoff, M., N.L. Wamer. Specificity of in vivo tumor rejection assessed by mixing immune spleen cells with target and unrelated tumor cells. Proc. Soc. Exp. Biol. Med. 1973; 144:813-818.

26. Espevik, T., J. Nissen-Meyer. A highly sensitive cell line, WEHI 164 clone 13, for measuring cytotoxic factor/tumor necrosis factor from human monocytes. J. Immunol. Melhods 1986,95: 99.105.

27. Hanssen, M.B., S.E. Nielsen, K. Berg. Re-examination and further development of a precise and rapid dye method for measuring cell growth/cell kill. J. Immunol. Methods 1989:119:203. 210.

28. Selkur, E.E. Measurement of renal blood flow. Meth. Med. Res. 1948;1:191-199.

29. Dejong, C.H.C., M.T. Kampman, N.E.P. Deutz, P.B. Soeters. Altered glutamine metabolism in rat portal drained viscera and hindquarter during hyperammonemía. Gastroenterology 1992;102:936.948.

30. Rose, B.D. Clinical physiology of acid-base and electrolyte disorders. 1977. Mc Graw-Hill Kogakusha LTD, Tokyo, $548 \mathrm{pp}$.

31. Norusis, M.J. ed. SPSS/PC+ V3.I BASE MANUAL for the IBM PC/XT/AT and PS/2. SPSS Inc., Chicago, USA.

32. Wait, R.B., K.U. Kahng. Renal failure complicating obstructive jaundice. 1989. Am. J. Surg. 1989;157:256-263.

33. Pitt, H.A., J.L. Cameron. R.G. Postier, T.R. Gadacz. Factors affecting mortality in biliary tract surgery. Am. J. Surg. 1981:141:66-72.

34. Hishida, A., N. Honda, M. Sudo, M. Nagase. Mechanisms of alteredl renal perfusion in the early stage of obstructive jaundice. Kidney Int. 1980;1:223-230.

35. Maessen, J.G., J.W. Greve, W.A. Buurman. Increased sensitivity to endotoxemia by tissue necrosis. Surgery 1991;109:154-159.

36. Froon, A.H.M., M.H.A. Bemelmans, J.W. Greve, C.J. van der Linden, W.A. Buurman. Increased levels of soluble Tumor Necrosis Factor receptors in sepsis syndrome:correlation with plasma creatinine. Crit. Care Med., in press.

37. Beutler, B., A. Cerami. Cachectin: More than a tumor necrosis factor. N. Engl. J. Med. 1987;316:379-385.

38. Better, O.S., S.G. Massry. Effect of chronic bile duct obstruction on renal handling of salt and water. J. Clin, Invest, 1975:51:402-411. 
39. Hamilton, G., S. Hofbauer, B. Hamilton. Endotoxin, TNF-alpha, Interleukin-6 and parameters of the cellular immune system in patients with intraabdominal sepsis. Scand. J. Infect. Dis. 1992;24:361-368.

40. Brockhaus, M., Y. Bar-Khayim, S. Gurwicz, A. Frensdorff, N. Haran. Plasma tumor necrosis factor soluble receptors in chronic renal failure. Kid. Int. 1992;42:663-667. 


\section{Chapter 6}

\section{INFLUENCE OF NEPHRECTOMY ON TUMOR NECROSIS FACTOR CLEARANCE IN A MURINE MODEL}

M.H.A. Bemelmans, D.J. Gouma, W.A. Buurman.

J. Immunol. 1993;150:2007-2017. 


\section{Summary}

TNF, a cytokine with multiple properties, is known to be rapidly inactivated in vivo. In patients with septic shock and kidney malfunction, conflicting data have been reported regarding the presence of TNF in the circulation. Recently, we have shown that these differences can be the result of the detection of free TNF vs TNF complexed with soluble TNF-R. Enhanced levels of soluble TNF-R have been reported in patients with kidney malfunction. Because the kidney is thought to play an important role in TNF and TNF-R metabolism, we investigated the influence of bilateral nephrectomy on TNF clearance and TNF-R regulation in a murine model. The data obtained show that bilateral nephrectomy results in circulating levels of immunologically detectable (ELISA), but not biologically active (bioassay), TNF. Injection of endotoxin results in significantly higher levels of immunologically detectable TNF in bilaterally nephrectomized mice compared with sham-operated mice, whereas biologically active levels were similar. To investigate the roles of TNF-R1 (P55) and TNF-R2 (P75) in this process, clearance of TNF was studied by injection of murine and human TNF. Murine TNF injection leads to comparable clearance of bioactive TNF in nephrectomized and sham operated mice $\left(t_{1 / 2} \pm 12 \mathrm{~min}\right)$. However, clearance of immunologically detectable murine TNF is significantly slower in nephrectomized mice compared with shamoperated mice ( $\mathrm{t}_{1 / 2}$ resp. $96 \mathrm{~min}$ vs $26 \mathrm{~min}$, respectively; $\mathrm{p}<0.05$ ). Administration of human TNF results in a significantly lower clearance in nephrectomized mice compared to sham operated mice $\left(t_{1 / 2}\right.$ resp. $108 \mathrm{~min}$ vs $25 \mathrm{~min}$, respectively; $\left.\mathrm{p}<0.05\right)$. This is observed for both bioactive human TNF and immunologically detectable human TNF. Based on the fact that murine TNF-RI ( $55 \mathrm{kDa}$ ) has a similar affinity for murine and human TNF, whereas murine TNF-R2 (75kDa) shows affinity only for murine TNF, the data obtained suggest an important role for TNF-R2 in inactivation and clearance of TNF by the kidney. Moreover, the data suggest that kidney malfunction affects TNF clearance, leading to increased amounts of circulating TNF-TNF-R complexes, which could function as a slow release reservoir for TNF.

\section{Introduction}

TNF is rapidly cleared from the circulation (1-3). The clearance mechanism seems to consist of two phases, first inactivation of the biologic activity of TNF and then clearance of the TNF protein. The bioinactivation is considered to be caused by binding to circulating soluble TNF Receptors (sTNF-R'), although other mechanisms have been reported (4-6). The kidney and the liver are thought to be responsible for clearance of the protein $(1,2,7)$.

Two types of TNFR have been identified (8-10), a 55k-Da receptor (TNF-R1) and a $75 \mathrm{kDa}$ receptor (TNF-R2). The $55-\mathrm{kDa}$ receptor has been implicated in various biologic functions of TNF. Antibodies against human TNF-R1 have been shown to behave as receptor antagonists and agonists, eliciting several TNF activities, such as 
cytotoxicity, synthesis of $\mathrm{PGE}_{2}$ and fibroblast proliferation (9,11-13). The function of the 75-kDa receptor is less well defined. Several reports have described $\mathrm{mAb}$ against TNF-R2 that only partially antagonize TNF responses and enhance the antagonistic effects of anti-TNF-R1 mAb (12-14). Recent data indicate a role for the TNF-R2 in thymocyte and T-cell proliferation (15); however, additional functions of TNF-R2 have yet to be identified.

Thus far, it is unclear to what extent sTNFR are involved in inactivation of TNF in the circulation. The presence of circulating sTNF-R, which has been reported in healthy and diseased individuals (16-20), supports the hypothesis that sTNF-R play a role in inactivation of the bioactivity of TNF in vivo. For rapid inactivation of increasing TNF levels as in experimental bacteremia (21), immediate elevation in STNF-R levels would be necessary. Compatible with this hypothesis, a TNF infusion was reported to result in a marked increase in TNF binding proteins in the serum (22). A rapid shedding of sTNF-R from non-neoplastic cells was shown for neutrophils upon activation with physiologic peptides (FMLP) or polypeptides (C5a or granulocyte/macrophage-CSF) of bacterial or human origin or pharmacologic agents that activate protein kinase C (PMA or A23187) (23). Moreover, an increase in circulating TNF after LPS administration to human volunteers was accompanied by a rapid increase of an undefined TNF inhibitor (21), which may be identical to STNF-R.

There are substantial data indicating a role for the kidney in clearance of sTNF-R $(18,24,25)$. Nevertheless, it is unclear whether the kidney is involved in clearance of complexes of TNF with sTNF-R or of native TNF protein.

In the present study, the role of the kidney in TNF metabolism is investigated in a murine model. The data presented show that bioactive TNF is rapidly inactivated in the circulation. The sTNF-R2 $(75 \mathrm{kDa})$ is suggested to play a major role in this process in mice. Furthermore, data are presented indicating that the kidney plays an important role in TNF metabolism by removing both TNF complexed with sTNF-R and native TNF from the circulation.

\section{Materials and Methods}

Animals. Female Swiss mice weighing 27 to 35 grams were obtained from Charles River Breeding Laboratories (Heidelberg, FRG.). They were maintained on a standard laboratory diet and were allowed free access to water.

Reagents. Escherichia coli O55:B5 LPS, 3-[4,5-dimethylthiazol-2-yl]-2,5 diphenyltetrazolium bromide (MTT), N,N-dimethylformamide (DMF), substrate o-phenyldiamine (OPD) and BSA were obtained from Sigma (St Louis, MO). Culture medium (CM) consisted of RPMI 1640 (GIBCO, Paisley, U.K.) supplemented with 10\% FCS (Hyclone, Logan, UT), $100 \mathrm{U} / \mathrm{ml}$ penicillin, and $100 \mu \mathrm{g} / \mathrm{ml}$ streptomycin (Flow, Irvine, U.K.). TN3 (26) is a hamster mAb specific for murine TNF, produced by Celltech (Slough, UK). SDS was obtained from Bio-Rad (Richmond, CA). The mAb 61 E71 
$\left(\mathrm{IgG}_{1}\right)$, an anti TNF antibody that inhibited the biologic function of TNF in both the L929 and WEHI bioassays was described previously (27). Peroxidase conjugated goat anti rabbit IgG was obtained from Jackson Immunoresearch Laboratories Inc. (Westgrove, PA). Polyclonal rabbit anti murine TNF antiserum. (RAMT) and rabbit antihuman TNF antiserum were produced by injecting rabbits with murine or human TNF, respectively. Human and murine rTNF were kindly provided by BASF/Knoll (Ludwigshafen, FRG).

Surgical Procedures. Female Swiss mice underwent surgery under a light ether anesthesia on a temperature-controlled mattress. The mice were divided randomly into two groups, a sham operated control group and a group, in which both kidneys were removed $(\mathrm{BN})$. After a midline abdominal incision was made, the vessel pedicles of the kidney were identified, the kidney was dissected from its surrounding tissue and ligatures were placed around the vessel pedicles of the kidney. After this procedure, the ligatures were removed in the sham operated group, whereas in the BN group ligatures were tied and the kidneys were removed. Special care was taken to prevent damage to the adrenal blood supply.

TNF and LPS administration. Murine TNF was administered i.p. at $250 \mathrm{ng} / \mathrm{mouse}$, in $0.5 \mathrm{ml}$ of PBS. Human TNF was administered in the same way at $1 \mu \mathrm{g}$ of human TNF dissolved in $0.5 \mathrm{ml}$ of PBS per mouse. LPS was also administered in $0.5 \mathrm{ml}$ of PBS.

ELISA for murine and human TNF. ELISA for murine TNF was performed as described earlier by Dentener (28). In short, a 96-well Immuno Maxisorp plate (Nunc, Roskilde, Denmark) was coated with TN3. A standard titration curve was obtained by making serial dilutions of a known sample of murine rTNF in 50\% normal murine serum. The plates were then washed and incubated with RAMT, followed by addition of an enzyme labeled anti-rabbit reagent and enzyme reaction. ELISA for human TNF was performed as described by Engelberts (27). In short, a 96-well Immuno-Maxisorp plate was coated with a murine anti-human TNF mAb 61E71. A standard titration curve was obtained by making serial dilutions of a known sample of human rTNF in normai murine serum. The plates were incubated with a polyclonal rabbit anti-humanTNF antiserum, followed by addition of an enzyme labeled anti-rabbit reagent and enzyme reaction. The detection limit for murine TNF is $50 \mathrm{pg} / \mathrm{ml}$ and for human TNF is $20 \mathrm{pg} / \mathrm{ml}$.

Human TNF measurement by Medgenix ELISA (Medgenix Diagnostics, Brussels, Belgium) was done as recommended. First the samples and standard were incubated for $2 \mathrm{~h}$ with continuous shaking and then the plates were washed, followed by incubation with an enzyme labeled anti-TNF for $2 \mathrm{~h}$ with continuous shaking. The plates were then washed again, followed by enzyme reaction. The detection limit for human $\mathrm{TNF}$, as given by Medgenix, is $3 \mathrm{pg} / \mathrm{ml}$. 
WEHI 164 cytotoxicity bioassay. Biologic TNF activity was measured by using the murine fibrosarcoma WEHI 164 cell line $(29,30)$. The MTT-method was used to assess cell killing as described previously (31). A standard titration curve was obtained by making serial dilutions of a known quantity of a human rTNF sample or murine rTNF sample, depending on which TNF was injected. To differentiate between human and murine TNF, antibodies inactivating human or murine TNF (mAb $61 E 71$ and TN3. respectively) were added in some experiments. The dilution giving rise to $50 \%$ lysis was correlated with the $\mathrm{LD}_{50}$ of the standard curve. The $\mathrm{LD}_{50}$ ranged between 10 and $40 \mathrm{pg} / \mathrm{ml}$.

Fast protein liquid chromatography (FPLC). Three hours after BN or sham operation, $100 \mu \mathrm{g}$ of LPS per mouse were administered. Two hours later, serum samples were collected. The sera were applied to a Superose 12 column (Pharmacia, Uppsala, Sweden) attached to an FPLC system (Pharmacia) with PBS as solvent. Column flow rate was $0.5 \mathrm{ml} / \mathrm{min}$. Fractions of $250 \mu \mathrm{l}$ were collected and then assayed in the ELISA for TNF activity. The elution positions (relative m.w.) of the samples containing TNF activity by ELISA were determined with respect to the following proteins of known m.w.: phosphorylase b (rabbit), 94,000; BSA, 67,000; OVA, 43,000; carbonic anhydrase (bovine), 30,000; trypsin inhibitor (soybean), 20,100; and $\alpha$-lactalbumin (bovine), 14,400 (Pharmacia).

Immunoprecipitation. Sham-operated and BN mice were given i.p. injections, $3 \mathrm{~h}$ after operation, of $2 \mu \mathrm{g}$ of murine ${ }^{125} \mathrm{I}$-TNF; murine rTNF was iodinated with Iodobeads (Pierce, Rockford, IL). Sixty minutes after the injection, blood was sampled and sera of three mice were mixed and subjected to immunoprecipitation. Immunoprecipitation of the serum, containing murine ${ }^{125}$ I-TNF was performed with rabbit anti-sTNF-R1, rabbit anti-sTNF-R2 (both a generous gift of Dr. D.V. Goeddel, Genentech, Ca) or RAMT-Ireated protein A-Sepharose spheres (Pharmacia). After careful washing, samples were run under reducing conditions by using SDS-Phastgel Gradient (10 to $15 \%$ ) on a Phast system (Pharmacia). As controls, two concentrations of murine ${ }^{125} \mathrm{I}$ TNF and sera of the aforementioned mice were run under reducing conditions. For autoradiography of the gels, Kodak XAR-5 film was used in combination with intensifieir screens.

Statistical analysis. Analysis of variance was used for comparison of differences in serum cytokine level̂s after nephrectomy or nephrectomy followed by LPS injection (32). Multiple regression analysis was used for comparison of detected levels of cytokines in the circulation after human or murine TNF injection in sham-operated mice and BN mice. Probability (p) values below 0.05 were considered to be statistically significant. 


\section{Results}

Spontaneous TNF levels in BN mice. In BN $(n=10)$ mice TNF was detected by ELISA in circulation $( \pm 200 \mathrm{pg} / \mathrm{ml})$ as soon as $2 \mathrm{~h}$ after nephrectomy (Fig. 1A). In contrast, no TNF was detected in sham-operated mice $(\mathrm{n}=10$; data not shown). In the time period from 2 to 16 hours, a minimal increase in serum TNF was observed. Thereafter, the condition of the mice deteriorated rapidly and TNF levels increased until sacrifice at $24 \mathrm{~h}$. Immunologically detected TNF appeared not to be biologically active, as assessed in the WEHI bioassay (Fig. 1A).

\section{Influence of $B N$ on TNF levels after} LPS administration. Three hours after BN $(n=8)$ or sham operation $(n=8)$, LPS was administered i.p. Circulating TNF levels, assessed by ELISA, peaked in both groups after $2 \mathrm{~h}$ (TNF peak level of $\mathrm{BN}$ vs sham-operated mice, 55 vs 10 $\mathrm{ng} / \mathrm{ml}$ ). TNF levels were significantly higher in BN mice, however, than in sham- operated mice (p<0.001) (Fig. IB), Moreover, TNF levels in BN mice declined more slowly and at $6 \mathrm{~h}$ after LPS injection TNF was still detectable in $\mathrm{BN}$ mice, whereas it had almost disappeared in the sham-operated mice. To study the nature of the immunologically detected TNF, plasma samples of BN $(n=4)$ and sham-operated mice $(n=4)$ taken $2 \mathrm{~h}$ after LPS injection were subjected to gel filtration chromatography. Subsequent sampling of $250 \mu \mathrm{I}$ fractions and TNF assessment by ELISA showed two peaks of TNF activity in the BN sera, a minor peak after $102 \mathrm{~min}(95 \mathrm{kDa})$ and a major peak
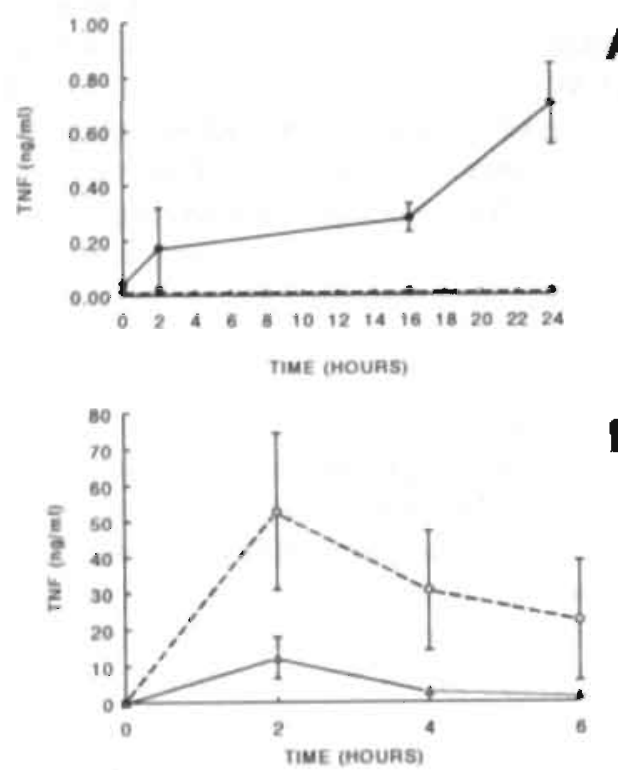

$\mathbf{B}$

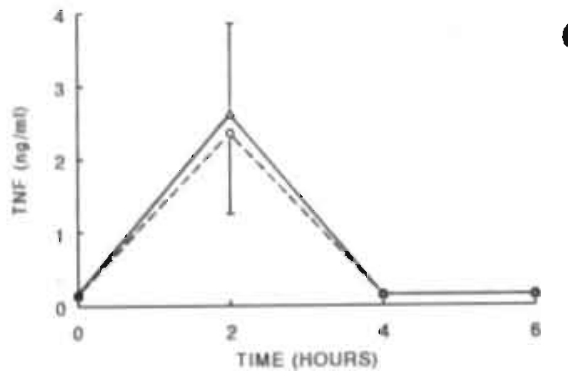

Figure 1: TNF levels in BN mice with or without LPS injection. (A) TNF levels in BN mice $(n=10)$. Solid line represents TNF levels as assessed by ELISA, dashed line represents data determined by WEHI bio-assay. Time scale marks h after nephrectomy. (B) TNF levels determined by ELISA, after LPS injection in BN, $n=8$ (open circles, dashed line) and shamoperated mice, $n=8$ (open triangles, solid line). Three hours after nephrectomy or sham operation LPS was given $(100 \mu \mathrm{g} /$ mouse i.p.) After 2, 4, and 6 h blood was taken. Each time point represents 8 mice in both groups. (C) TNF levels from of experiment described in (B) measured by WEHI bioassay. Data are expressed as means $\pm \mathrm{SD}$. 
after $122 \mathrm{~min}$ (35 kDa)(Fig. 2A). Sera of sham-operated mice, however, revealed only one peak after $124 \mathrm{~min}$ ( $35 \mathrm{kDa}$ ) (Fig. 2B).

The levels of biologically active TNF, as assessed by WEHI bioassay, appeared to be virtually identical for LPS-injected BN and sham-operated mice (Fig. 1C). There was only a minimal bioactivity in the sera of both groups of mice after 4 or $6 \mathrm{~h}$. The patterns of immunoassay and bioassay in sham-operated mice were largely similar, although higher levels were found in the sera of sham-operated mice in the ELISA compared with the WEHI bioassay.

Figure 2: Analysis of immunologically detectable TNF in plasma from sham-operated and $B N$ mice by size exclusion chromatography. Three hours after $B N(n=4)$ or sham-operation $(\mathrm{n}=4), 100 \mu \mathrm{g}$ of LPS per mouse were given i.p. Two h later serum samples were collected and applied to a Superose 12 column attached to an FPLC system. The eluate was collected in $250 \mu \mathrm{l}$ fractions and assayed by ELISA. A standard titration curve is shown as a dashed line with subsequently determined $m$. $w$. on the right $\mathrm{Y}$-axis and volume after elution on the $\mathrm{X}$ axis. The solid line represents TNF levels in the collected fractions plotted against the left Y-axis. (A) FPLC data for serum of BN mice (B) FPLC data for serum of sham-operated mice.
A

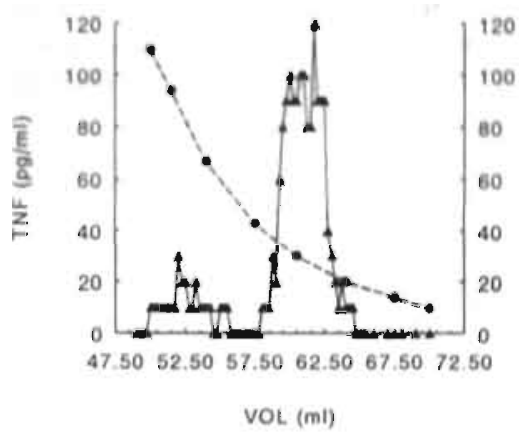

B

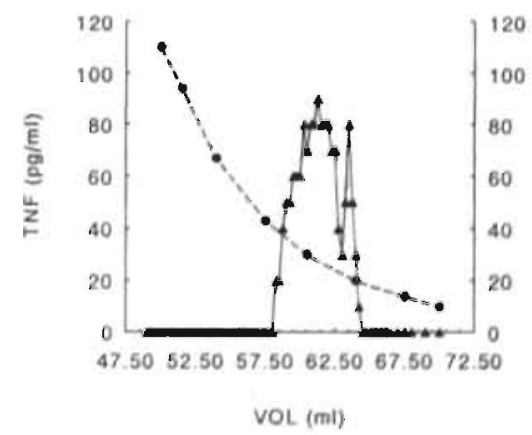

Effect of unilateral nephrectomy (UN) on TNF metabolism. Although one kidney is sufficient to maintain adequate clearance of urea and creatinine, we studied whether this holds also for clearance of TNF. In non treated UN mice $(n=8)$, immunologically and biologically active TNF levels were below the detection limit (data not shown). 
LPS administration $3 \mathrm{~h}$ after $\mathrm{UN}(\mathrm{n}=6)$ or sham operation $(\mathrm{n}=6)$ resulted in similar TNF levels in both groups with a peak after $2 \mathrm{~h}$ and with identical kinetics in both ELISA and bioassay; data from the WEHI bioassay are not shown (Fig. 3). Evidently, one functioning kidney is sufficient for maintenance of normal TNF clearance.

Figure 3: Circulating TNF levels in Unilateral nephrectomized (UN: $n=6$ ) and sham-operated mice $(n=6)$ after LPS administration. Three hours after UN or sham operation. LPS was injected i.p. at $100 \mu \mathrm{g}$ per mouse. Blood was collected after 2 and $6 \mathrm{~h}$. Open circles and dashed line represent circulating TNF levels in UN mice, open triangles and solid line represent circulating TNF levels in sham-operated mice. TNF was assessed by ELISA. Data are expressed as means \pm SD.

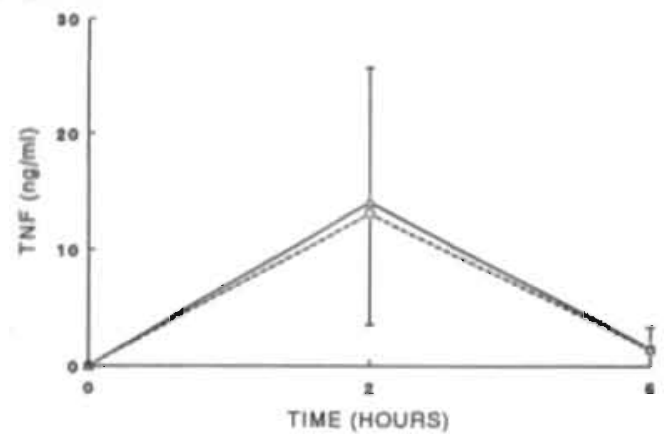

Effects of adrenalectomy. The pituitary adrenal axis is known to be involved in the regulation of TNF kinetics (33-35). Although macroscopic inspection indicated that the arterial supply to the adrenals was not damaged during nephrectomy, we investigated whether the changes in TNF kinetics observed after nephrectomy were the result of damage to the adrenals.

Adrenalectomy did not result in biologically nor immunologically detectable TNF levels (data not shown). LPS administration $3 \mathrm{~h}$ after adrenalectomy resulted, in agreement with previous data, in rapid death in the majority of animals (five of eight)(33-35). Moreover, TNF levels in the survivors $(n=3)$ did not decrease after the peak at $2 \mathrm{~h}$, but remained elevated at a plateau level. It was, therefore, concluded that nephrectomy in our experiments did not result in damage to the adrenals and that results obtained with nephrectomized animals are specific for the absence of kidney function.

Clearance of murine rTNF. Murine rTNF was administered to $\mathrm{BN}(\mathrm{n}=24)$ and shamoperated $(\mathrm{n}=24)$ mice ( $3 \mathrm{~h}$ after the initial operation) to delineate the role of the kidney in the TNF kinetics (six mice per time point in both groups). The data demonstrate that immunologically detectable murine TNF was removed significantly more slowly from the circulation in $B N$ mice $\left(T_{1 / 2}= \pm 96 \mathrm{~min}\right)$ compared with sham-operated mice $\left(T_{1 / 2}=\right.$ $\pm 26 \mathrm{~min})(\mathrm{p}<0.05$; Fig. 4A). In contrast, removal of biologically active TNF from the circulation was rapid and appeared to be similar in BN and sham-operated mice (Fig. 4B).

Biologically active TNF in both groups was approximately $0.75 \mathrm{ng} / \mathrm{ml}$ at 20 minutes after administration of murine TNF and declined rapidly thereafter (half-life in both 
groups $\pm 12 \mathrm{~min}$ ), whereas levels of immunologically detectable TNF in the sera were approximately $11 \mathrm{ng} / \mathrm{ml}$ in $\mathrm{BN}$ mice and $5.5 \mathrm{ng} / \mathrm{ml}$ in sham-operated mice at that time point. At $60 \mathrm{~min}$, substantial levels of immunologically detectable TNF were present in both groups, although biologically active TNF was hardly detectable. These data indicate that the differences in TNF levels observed in endotoxin treated $\mathrm{BN}$ and shamoperated mice were not caused by differences in TNF production, but rather by differences in removal of TNF from the circulation.

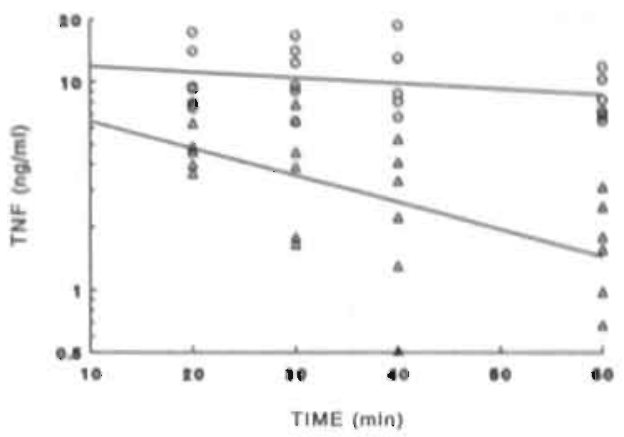

Figure 4: Clearance of murine rTNF in BN ( $n=24$; open circles) or sham-operated mice ( $n=24$; open triangles). Three hours after nephrectomy or sham operation, individual mice received $250 \mathrm{ng} /$ mouse murine rTNF i.p. and blood was taken after $20,30,40$ and $60 \mathrm{~min}$. At each time point 6 mice were tested.

(A) Circulating murine TNF levels determined by ELISA (BN vs sham-operated $\mathrm{p}<0.05$ ).

(B) murine TNF levels measured by WEHI bioassay. The continuous lines represent linear regression analysis of the TNF values.

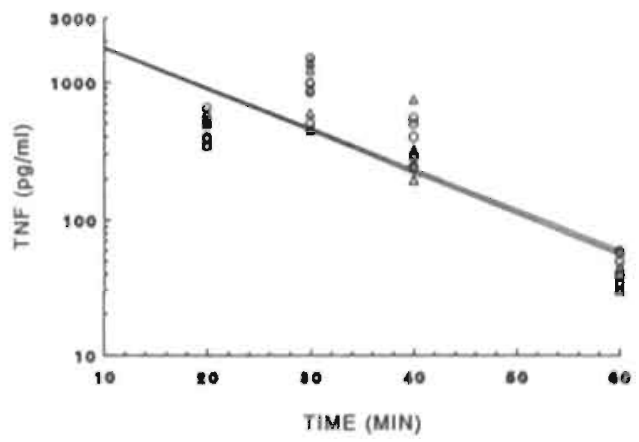

Clearance of human rTNF in mice after nephrectomy. After injection of human rTNF in mice ( $3 \mathrm{~h}$ after surgery), the clearance. of TNF can be assessed accurately, because the techniques used to detect human TNF by ELI ISA and WEHI bioassay allow differentiation between exogenous human TNF and possible endogenously produced murine TNF. Moreover, the use of human TNF offered the possibility of delineation of the role of TNF-R2 in the kinetics of TNF bioinactivation, because murine TNF-R2 lacks affinity for human TNF.

BN mice $(n=32)$ cleared human rTNF more slowly than did sham-operated mice $(n=32) ; \quad\left(T_{1 / 2}=108 \min\right.$ vs $T_{1 / 2}=25 \mathrm{~min} ; \mathrm{p}<0.05$; Fig. 5A). At every time point eight mice per group were assayed. The data obtained by ELISA, which is specific for 
human TNF, were similar to those obtained by bioassay in the presence of anti-murine TNF antibody (Fig. 5B), which permits the selective detection of human TNF, emphasizing the fact that our ELISA selectively recognizes sTNF-R-free biologically active human TNF (27). The results obtained with the Medgenix ELISA, which is known to recognize free TNF as well as complexes of sTNF-R and TNF (sTNF-R-TNF), were identical to the data obtained with our own ELISA (Fig. 5C). Obviously, the bioactivity of human TNF was not inactivated after administration. Furthermore, it appeared that administration of exogenous human TNF resulted in significant release of murine TNF (approximately $1 \mathrm{ng} / \mathrm{ml}$ ), which was immunologically as well as biologically detectable (data not shown).

Figure 5: Clearance of human rTNF in BN ( $n=32 ;$ open circles) and sham-operated mice ( $n=32$; open triangles). Three hours after nephrectomy or sham operation, individuall mice received I $\mu \mathrm{g} /$ mouse human rTNF i.p. and blood was taken after $60,100,140$ and 180 min. At each time point 8 mice were tested. (A) Circulating human TNF levels determined by ELISA (BN vs sham-operated $\mathrm{p}<0.05$ ),

(B) human TNF levels measured by WEHI bioassay (BN vs sham-operated $\mathrm{p}<0.05$ ),

(C) human TNF levels determined with the Medgenix ELISA ( 3 mice per time point; BN vs sham-operated $\mathrm{p}<0.05$ ). The continuous lines represent linear regression analysis of the data.

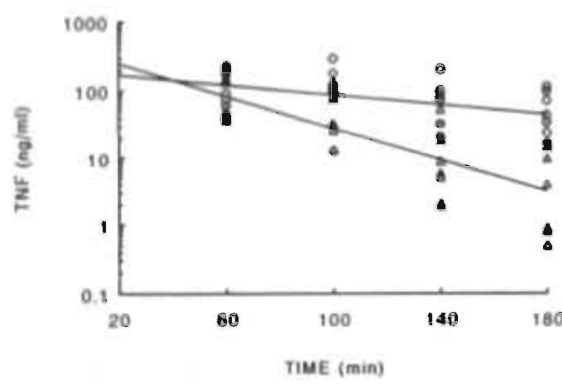

A

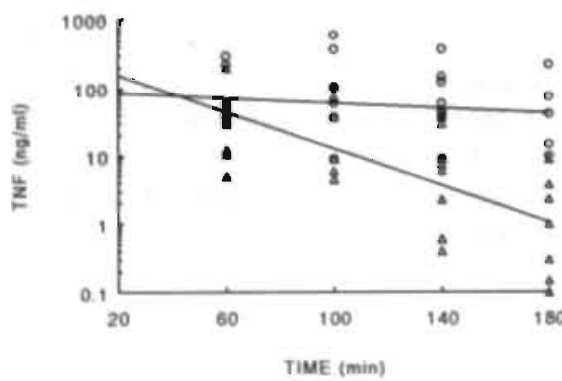

B

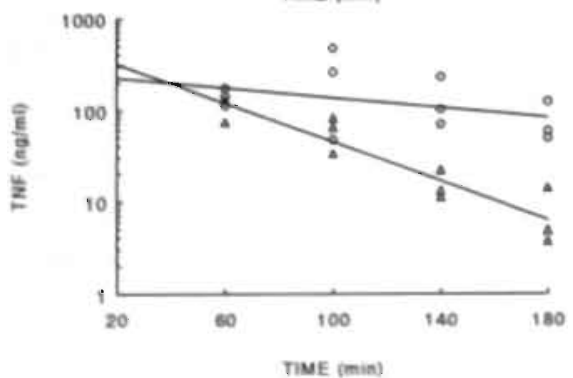




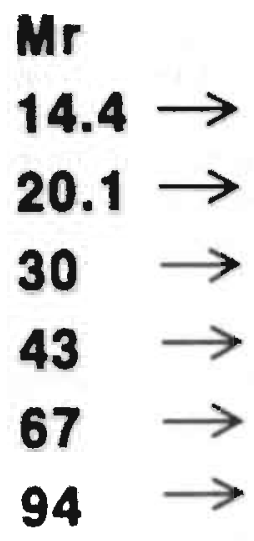

\section{A $B$ C C $\quad D \quad E \quad F$}

Figure 6: Immunoprecipitation of circulating murine TNF with anti-TNF-R and anti-murine TNF antibodies. Sera of $\mathrm{BN}$ mice given injections of murine ${ }^{125} \mathrm{I}$-TNF were subjected to immunoprecipitation with anti-TNF-R1, anti-TNF-R2 or RAMT. After precipitation, the samples were separated by reducing SDS-PAGE and visualized by using autoradiography. Lanes $\mathrm{A}$ and $\mathrm{B}$ : murine ${ }^{125} \mathrm{I}-\mathrm{TNF}$ controls; lane C: anti-TNF-R1; lane D: blood of murine ${ }^{125} \mathrm{I}-\mathrm{TNF}-$ injected BN mice; lane E: anti-TNFR2; lane F: RAMT. The positions of the molecular mass standards are indicated (left).

Immunoprecipitation studies. Serum samples from BN mice and sham-operated mice given injections of murine ${ }^{125}$ I-TNF were immunoprecipitated with either rabbit antisTNF-R1, anti-sTNF-R2, or RAMT antibodies. From the sera of sham-operated mice only minimal amounts of counts were precipitated, as was expected from the clearance data described above. In BN mice in a typical experiment $7 \mathrm{cpm} / \mu \mathrm{l}$ were precipitated with anti-sTNF-R1, $99 \mathrm{cpm} / \mu \mathrm{l}$ with anti-sTNF-R2 and $19 \mathrm{cpm} / \mu \mathrm{l}$ with RAMT, whereas in sham-operated mice these data were $5 \mathrm{cpm} / \mu \mathrm{l}$ after precipitation with anti-sTNF-R1, $12 \mathrm{cpm} / \mu \mathrm{l}$ with anti-sTNF-R2, and $10 \mathrm{cpm} / \mu \mathrm{l}$ with RAMT. When subjected to SDSPAGE analysis, the BN mouse serum samples, precipitated with rabbit anti-sTNF-R2 as well as the samples precipitated with RAMT, revealed a specific band of $\approx 17 \mathrm{kDa}$ on the autoradiogram (Fig. 6). Immunoprecipitation with anti-sTNF-R1 however, revealed only very faint bands. 


\section{Discussion}

Bilateral nephrectomy mice resulted in the presence of immunologically detectable TNF (by ELISA), whereas bioactivity could not be detected. In LPS-treated mice, removal of the kidney appeared to prolong the presence of immunologically detectable TNF, whereas the disappearance rate of biologically active TNF did not seem to be affected. The chromatographic data indicated that in the serum of BN mice, in addition to a low molecular mass fraction ( $35 \mathrm{kDa}$ ) with TNF activity, which has been reported to represent the native TNF molecule $(18,36)$, a high molecular mass fraction $(95 \mathrm{kDa})$ with immunologically detectable TNF activity was present. The high molecular mass fraction was absent in normal LPS-treated mice. These molecular masses correlate well with those found in mixtures of STNF-R and TNF (37). Based on the presence of the high molecular mass TNF activity, we suggest that in BN mice, a substantial amount of TNF complexed with sTNF-R or another binding protein is present. The data obtained by immunoprecipitation with anti-sTNF-R2 in combination with the data obtained with RAMT, both of which precipitate murine ${ }^{125} \mathrm{I}-\mathrm{TNF}$, support our observation, that sTNF-R2-TNF complexes circulate in BN mice. Because RAMT precipitation led to the specific $17 \mathrm{kDa}$ band, it appears that the ELISA, that was used to measure the circulating TNF in these mice (and in which the very same RAMT was used as detecting mAb) does not recognize TNF split products but, rather, recognizes TNFTNF-R complexes.

To further elucidate the role of the kidney in TNF clearance, exogenous murine TNF was administered to normal and BN mice. The data obtained were similar to those obtained with endotoxin injection. The half-life of biologically active murine TNF was approximately $12 \mathrm{~min}$ in both $\mathrm{BN}$ mice and normal mice. The half-life of immunologically detectable TNF increased from $26 \mathrm{~min}$ in normal mice to approximately 100 min in BN mice $(\mathrm{p}<0.05)$. These data strongly suggest that two different mechanisms are responsible for the clearance of TNF, i.e., the inactivation of the bioactivity of the TNF molecule and the clearance of the protein. Protein clearance appeared to be largely dependent on the kidney. As mentioned above, TNF-inactivation is most likely caused by sTNF-R, which form complexes with $\operatorname{TNF}(18,37)$, although various binding proteins and other mechanisms, such as inactivation of TNF by proteolytic enzymes released by stimulated human neutrophils have also been reported $(4,5)$.

To elucidate the potential role of the two TNF-R in this inactivation mechanism, we administered exogenous human TNF. Because the murine TNF-R2 (75 kDa) lacks affinity for human TNF $(15,38)$, such experiments offered the opportunity to differentiate between the kinetics of murine TNF and human TNF and to unravel possible functional differences between the two receptors. The experiments show that mice are less effective in clearing both biologically active human TNF and immunologically detectable human TNF, leading to nearly equal half lives for bioactive human TNF and immunologically detectable human TNF. 
Moreover, biologically active human TNF was cleared with a half life similar to that of immunologically detectable murine TNF. Thus it seems that human TNF is not inactivated during circulation. We observed no difference between the curves for immunologically detectable human TNF obtained with our own ELISA, which does not detect human TNF complexed with sTNF-R, and those obtained with the Medgenix ELISA, which detects free human TNF and also human TNF complexed with sTNF-R (39). This strongly supports our suggestion that human TNF complexes are absent in the case of exogenous human TNF administration and that the inactivation of human TNF is negligible.

Further evidence for the lack of biologic inactivation and a renal clearance of TNF was found in nephrectomized mice. The half life for bioactive human TNF was $108 \mathrm{~min}$, being similar to the clearance of the immunologically detectable human TNF in these mice. This value is similar to the half life of approximately $100 \mathrm{~min}$. for immunologically detectable murine TNF in BN mice, indicating that inactivation of human TNF is absent. Furthermore, it appears that, in addition to the kidney, other organs are playing a role in clearance of TNF with a substantially longer half life, because the absence of the kidney did not completely block TNF clearance.

Based on the facts that human TNF lacks affinity for the murine TNF-R2 and that human TNF in contrast to murine TNF is not inactivated in circulation, it seems that sTNF-R2 is functional in inactivation of the bioactivity of circulating murine TNF in vivo.

Pilot experiments aimed at determining the influence of nephrectomy with or without LPS injection on circulating sTNF-R levels, showed that these treatments led to a rapid increase (approximately 10 fold for sham-operated mice and $>40$ fold for BN mice) of sTNF-R2 (data not shown). Soluble TNF-R1 levels were approximately 60 to 100 $\mathrm{pg} / \mathrm{ml}$ in normal mice and showed only a moderate increase after LPS injection and nephrectomy. Because sTNF-R2 is present at a concentration approximately 50 to 60 times higher than that of sTNF-R 1 and because the $\mathrm{K}_{\mathrm{d}}$ of sTNF-R $\mathrm{i}$ is $200 \mathrm{pM}$ and the $\mathrm{K}_{\mathrm{d}}$ of sTNF-R2 is $50 \mathrm{pM}(38)$, it can be calculated that in vivo, circulating sTNF-R2 can bind up to 200 times more TNF than circulating sTNF-R1. These data, strongly support our hypothesis concerning the inactivation of TNF by sTNF.R2.

To rapidly inactivate circulating TNF, sTNF-R must be shed rapidly and in large quantities. The data on the sTNF-R kinetics after endotoxin and human or murine TNF administration strongly support this hypothesis. sTNF-R2 levels are substantially higher than sTNF-R1 levels in these situations, indicating that, at least in mice, an important function of sTNF-R2 is to be rapidly shed to inactivate circulating native TNF. In the case of human TNF administration, a rise in sTNF-R2 cannot lead to bioinactivation of TNF, explaining the difference between the murine and human TNF data. This seems to be an important functional difference between TNF-R2 and TNF-R1, in addition to the reported functional differences between TNF-R2 and TNF-R1 in T-cell proliferation and thymocyte proliferation (15). 
Based on a half life of human rTNF of approximately $100 \mathrm{~min}$ in BN mice (clearance from other organs) and a half life of $25 \mathrm{~min}$ in sham-operated operated mice (clearance from the kidney and other organs), a half life of approximately $33 \mathrm{~min}$ can be calculated for kidney clearance. Assuming that these clearance processes are similar for human and murine TNF, it can be calculated that the bioinactivation of murine TNF takes place with a half life of approximately $22 \mathrm{~min}$. By following this calculation for murine TNF bioactivity, a half life of approximately $18 \mathrm{~min}$ in $\mathrm{BN}$ mice would be expected, whereas we observed a half life of only $12 \mathrm{~min}$. A potential explanation for this fact, is that the methods used are not sufficiently sensitive to detect this difference. Moreover, we cannot exclude a minor role for proteolytic enzymes in the inactivation mechanism $(4,5)$. In agreement with our data, different groups have shown that TNF is rapidly cleared from the circulation $\left(\mathrm{t}_{1 / 2}= \pm 20 \mathrm{~min}\right)$ and that the kidney plays a role in TNF clearance $(1,2,3,7,40)$. Furthermore, the liver, skin, lung, and gastrointestinal tract were observed to concentrate injected ${ }^{125} \mathrm{I}-\mathrm{TNF}-\alpha$ relative to plasma $(1,7,41)$. In skin, lung, and gastrointestinal tract, however, specific binding could not be demonstrated. The kidney and, to a lesser extent, the liver seem, therefore, responsible for clearance of TNF $(2,3,7,40)$.

Assuming that a similar mechanism exists in humans, renal dysfunction, which is often

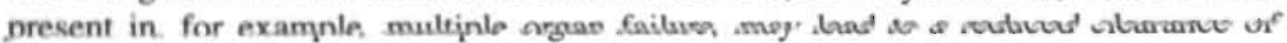
TNF-sTNF-R complexes. The resulting increase of circulating sTNF-R complexes could function as a slow release reservoir for bioactive TNF $(16,42)$, thus enhancing the pathophysiologic effects of TNF.

TNF is reported to circulate as a dimer or a compact trimer (37,43-45); a complex of TNF with sTNF-R would be retained by the glomerular filter and the only possible way of entering into the tubules would be by peritubular uptake $(46,47)$. However, a single TNF molecule could easily pass the glomerular membrane. In agreement with previous reports describing the kidney as the major organ regulating peripheral TNF levels, clearance of both native and complexed TNF may occur via peritubular binding to the renal glycoprotein ligand uromodulin $(48,49)$. The reported high levels of circulating binding protein in patients with renal failure and the high concentrations of sTNFR in the urine of these patients $(18,24,25)$ support the role of the kidney in clearance of the sTNF-R protein, possibly both free and complexed with TNF.

Here we present data that strongly suggest that circulating TNF, is substantially inactivated by rapid shedding of STNF-R2, by a thus far unresolved mechanism, and subsequent binding of TNF: In the presence of normal kidney function, these TNFsTNF-R complexes are cleared by the kidney. However, the experiments with human TNF in mice indicate that the kidney is also capable of clearing native TNF. The rapid inactivation of biologically active TNF is an important protective mechanism that, taking into account the $\mathrm{K}_{\mathrm{d}}$ of 50pM for sTNF-R2-TNF complexes, leads to very low effective bioactive TNF levels. Future experiments are required to elucidate, whether inactivated TNF, in addition to bioactive TNF, plays a role in the pathophysiology of TNF related diseases. 


\section{References}

1. Beutler, B.A., I.A. Milsark, and A. Cerami. Cachectin/ tumor necrosis factor: production, distribution, and metabolic fate in vivo. J. Immunol. 1985:135:3972-3977.

2. Ferraiolo, B.L., J.A. Moore, D. Crase, P. Gribling, H. Wilking, and R.A. Baughman. Pharmacokinetics and tissue distribution of recombinant human tumor necrosis factor- $\alpha$ in mice. Drug Metab. Dispos. 1988;16:270-275.

3. Chapman, P.B., T.J. Lester, E.S. Casper, J.L. Gabrilove, G.Y. Wong, S.J. Kempin, P.J. Gold, S. Welt, R.S. Warren, H. Fletcher Starnes, S.A. Sherwin, L.J. Old, and H.F. Oettgen. Clinical pharmacology of recombinant human tumor necrosis factor in patients with advanced cancer. J. Clin. Oncol. 1987;5:1942-1951.

4. Kessel van, K.P.M. J.A.G. van Strijp, and J. Verhoef. Inactivation of recombinant human tumor necrosis factor- $\alpha$ by proteolytic enzymes released from stimulated human neutrophils. J. Immunol. 1991:147:3862-3868.

5. Nortier, J., P. Vandenabeele, E. Noel, Y. Bosseloir, M. Goldman, and M. Deschodtlanckman. Enzymatic degradation of tumor necrosis factor by activated human neutrophils - the role of elastase. Life Sci. 1991,49:1879-1886.

6. Lantz, M., H. Thysell, E. Nilsson, and I. Olsson. On the binding of tumor necrosis factor (TNF) to heparin and the release in vivo of the TNF-binding protein 1 by heparin. J. Clin. Invest, 1991;88:2026-2031.

7. Pessina, G.P., A. Pacini, V. Bocci, E. Maioli, and A. Naldini. Studies on tumor necrosis factor (TNF): II. Metabolic fate and distribution of human recombinant TNF. Lymphokine Res. 1987;6:35-44.

8. Engelmann, H., H. Holtmann, C. Brakebush, Y.S. Avni, I. Sarov, Y. Nophar, E. Hadas, O. Leitner, and D. Wallach. Antibodies to a soluble form of a tumor necrosis factor (TNF) receptor have TNF-like activity. J. Biol. Chem. 1990;265:I4497-14504.

9. Engelmann, H., D. Novick, and D. Wallach. Two tumor necrosis factor-binding proteins purified from human urine: evidence for immunological cross-reactivity with cell surface tumor necrosis factor receptors. J. Biol. Chem. 1990;265:1531-1536.

10. Brockhaus, M., H.J. Schoenfeld, E.J. Schlaeger, W. Hunziker, W. Lesslauer, and H. Loetscher. Identification of two types of tumor necrosis factor receptors on human cell lines by monoclonal antibodies. Proc. Natl. Acad. Sci. USA. 1990;87:3127-3131.

11. Espevik, T., M. Brockhaus, H. Loetscher, U. Nonstad, and R. Shalaby. Characterization of binding and biological effects of monoclonal antibodies against a human tumor necrosis factor receptor. J. Exp. Med. 1990;171:415-426.

12. Shalaby, M.R., A. Sundan, H. Loetscher, M. Brockhaus, W. Lesslauer, and T. Espevik. Binding and regulation of cellular functions by monoclonal antibodies against human tumor necrosis factor receptors. J. Exp. Med. 1990;172:1517-1520.

13. Naume, B., R. Shalaby, W. Lesslauer, and T. Espevik. Involvement of the 55- and 75-kDa tumor necrosis factor receptors in the generation of lymphokine-activated killer cell activity and proliferation of natural killer cells. J. Immunol, 1991;146:3045-3048.

14. Hohmann, H., M. Brockhaus, P.A. Baeuerle, R. Remy, R. Kolbeck, and A.P.G.M. van Loon. Expression of the Types A and B tumor necrosis factor (TNF) receptors is independently regulated, and both receptors mediate activation of the transcription factor NF-kB. J. Biol. Chem. 1990;265:22409-22417.

15. Tartaglia, L.A., R.F. Weber, I.S. Figari, C. Reynolds, M.A. Palladino, and D.V. Goeddel. The two receptors for tumor necrosis factor mediate distinct cellular responses. Proc. Natl. Acad. Sci. USA. 1991;88:9292-9296. 
16. Engelmann, H., D. Aderka, M. Rubinstein, D. Rotman, and D. Wallach. A tumor necrosis factor-binding protein purified to homogeneity from human urine protects cells from tumor necrosis factor toxicity. J. Biol. Chem, 1989;264:11974-11980.

17. Seckinger, P., S. Isaaz, and J.M. Dayer. Purification and biologic characterization of a specific tumor necrosis factord inhibitor. J. Biol. Chem. 1989;264:11966-11970.

18. Peetre, C., H. Thysell, A. Grubb, and I. Olsson. A tumor necrosis factor binding protein is present in human biological fluids. Eur. J. Haematol. 1988;41:414-419.

19. Nophar, Y., O. Kemper, C. Brakebush, H. Engelmann, R. Zwang, D. Aderka, H. Holtman, and D. Wallach. Soluble forms of tumor necrosis factor receptors (TNF-Rs): the cDNA for the type 1 TNF-R, cloned using amino and sequence data of its soluble form, encodes both the cell surface and a soluble form of the receptor. EMBO J. 1990;9:3269-3278.

20. Seckinger, P., S. Isaaz, and J.M. Dayer. A human inhibitor of tumor necrosis factor- $\alpha$. J. Exp. Med. 1988;167:1511-1516.

21. Spinas, G.A., D. Bloesch, M.T. Kaufmann, U. Keller, and J.M. Dayer. Induction of plasma inhibitors of interleukin 1 and TNF $\alpha$ activity by endotoxin administration to normal humans. Am. J. Physiol. 1990;259:R993-R997.

22. Lantz, M., S. Malik, M.L. Stevin, and I. Olsson. Infusion of tumor necrosis factor (TNF) causes an increase in circulating TNF-binding proteins. Cytokine 1990;2:402-406.

23. Porteu, F., and C. Natan. Shedding of tumor necrosis factor by activated human neutrophils. J. Exp. Med. 1990:172:599-607

24. Olsson, O., M. Lantz, E. Nilsson, C. Peetre, H. Thysell, A. Grubb, and G. Adolf. Isolation and characterization of a tumor necrosis factor binding protein from urine. Eur. J. Haematol. 1989:42:270-275

25. Lantz, M., U. Gullberg, E. Nilsson, and L. Olsson. Characterization in vitro of a human tumor necrosis factor-binding protein. J. Clin. Invest. 1990;86:1396-1442.

26. Sheehan, K.C.F., N.H. Ruddle, and R.D. Schreiber. Generation and characterization of hamster monoclonal antibodies that neutralizes murine tumor necrosis factors. J. Immunol. 1989;142:3884-3893.

27. Engelberts, 1., A. Moller, G.J. M. Schoen, C.J. van der Linden, and W.A. Buurman. Evaluation of measurement of human TNF in plasma by ELISA. Lymphokine Res. 1991;10:69-76.

28. Dentener, M.A., J.W. Greve, J.G. Maessen, and W.A. Buurman. Role of tumor necrosis factor in the phenomenon of the enhanced sensitivity of animals to endotoxin after exposure to lead. Immunopharmacol. Immunotoxicol. 1989;11:321-324.

29. Rollinghoff, M., and N.L. Warner. Specificity of in vivo tumor rejection assessed by mixing immune spleen cells with target and unrelated tumor cells. Proc. Soc. Exp. Biol. Med. $1973 ; 144: 813-818$.

30. Espevik, T., and J. Nissen-Meyer. A highly sensitive cell line, WEHI 164 clone 13 , for measuring cytotoxic factor /tumor necrosis factor from human monocytes. J. Immunol. Methods. 1986:95:99-105.

31. Hanssen, M.B., S.E. Nielsen, and K. Berg. Re-examination and further development of a precise and rapid dye method for measuring cell growth/cell kill. J. Immunol. Methods. 1989:119:203-210.

32. Norusis, M.J. ed. SPSS/PC+ V3.1 Base Manual for the IBM PC/XT/AT and PS/2. SPSS Inc., 1988, Chicago, USA.

33. Bertini, R., M. Bianchi, and P. Ghezzi. Adrenalectomy sensitizes mice to the lethal effects of interleukin I and tumor necrosis factor. J. Exp. Med. 1988;167:1708-1712.

34. Silverstein, R., B.R. Turley, C.A. Christoffersen, D.C. Johnson, and D.C. Morrison. Hydrazine sulfate protects d-galactosamine sensitized mice against endotoxin and tumor necrosis factor/cachectin lethality: evidence of a role for the pituitary. J. Exp. Med. 1991;173:357-365. 
35. Zuckerman, S.H., J. Shellhaas, and L.D. Butler. Differential regulation of lipopolysaccharideinduced interleukin 1 and tumor necrosis factor synthesis: effects of endogenous and exogenous glucocorticoids and the role of the pituitary-adrenal axis. Eur. J. Immunol. 1989;19:301. 305 .

36. Smith, R.A., M. Kirstein, W. Fierst, and C. Baglioni. Species specificity of human and murine tumor necrosis factor. J. Biol. Chem. 1986;261:14871-14874,

37. Pennica, D., W.J. Kohr, B.M. Fendly, S.J. Shire, H.E. Raab, P.E. Borchardt, M. Lewis, and D.V. Goeddel. Characterization of a recombinant extracellular domain of the type-1 tumor necrosis factor receptor; evidence for tumor necrosis factor- $\alpha$ induced receptor aggregation. Biochemistry 1992;31:1134-1141.

38. Lewis, M., L.A. Tartaglia, A. Lee, G.L. Benett, G.C. Rice, G.H.W. Wong, E.Y. Chen, and D.V. Goeddel. Cloning and expression of cDNAs for two distinct murine tumor necrosis factor receptors demonstrate one receptor is species specific. Proc. Natl, Acad. Sci. USA. $1991 ; 88: 2830-2834$.

39. Engelberts, I., S. Stevens, G.J.M. Francot, C.J. van der Linden, and W.A. Buurman. Evidence for different effects of soluble TNF-receptors on various TNF measurements in human biological fluids. Lancet, 1991;338:515-516.

40. Ferraiolo, B.L., J. McCabe, S. Hollenbach, B. Hultgren, R. Pitti, and H. Wilking. Pharmacokinetics of recombinant human tumor necrosis factor- $\alpha$ in rats. Drug Metab. Dispos. 1989:17:369-372.

41. Palladino, M.A., M. Refaat Shalaby, S.M. Kramer, B.L. Ferraiolo, R.A. Baughman, A.B. Deleo, D. Crase, B. Marafino, B.B. Aggarwal, I.S. Figari, D. Liggitt, and J.S. Patton. Characterization of the antitumor activities of human tumor necrosis factor- $\alpha$ and the comparison with other cytokines: induction of tumor-specific immunity. J. Immunol. 1987; 138:4023-4032.

42. Aderka, D., H. Engelmann, Y. Maor, C. Brakebush, and D. Wallach. Stabilization of the bioactivity of tumor necrosis factor by its soluble receptors. J. Exp. Med. 1992;175:323-329.

43. Smith, R.A., and C. Baglioni. The active form of tumor necrosis factor is a trimer. J. Biol. Chem. 1987;262:695I-6954.

44. Eck, M.J., B. Beutler, G. Kuo, J.P. Merryweather, and S.R. Sprang. Crystallization of trimeric recombinant human tumor necrosis factor (cachectin). J. Biol. Chem. 1988:263:12816-12819.

45. Petersen, C.M., A. Nykjaer, B.S. Christansen, L. Heickedorff, S.C. Mogendsen, and B. Moller. Bioactive human recombinant tumor necrosis factor- $\alpha$ : an unstable dimer? Eur. J. Immunol. 1989;19:1887-1894.

46. Strober, W., and T.A. Waidmann. The role of the kidney in the metabolisnn of plasma proteins. Nephron. 1974;13:35-66.

47. Dam ten M.A.G.J. The renal handling of low molecular weight proteins in man. Ph. D. Thesis, 1991. Amsterdam, The Netherlands.

48. Hession, C., J.M. Decker, A.P. Sherblom, S. Kumar, C.C. Yue, R.J. Mattaliano, R. Tizard, E. Kawashima, U. Schmeissner, S. Heletky, E.P. Chow, C.A. Burne, A. Shaw, and A.V. Muchmore. Uromodulin (Tamm-Horsfall glycoprotein): a renal ligand for lymphokines. Science. 1987;237:1479-/484.

49. Bichler, K.H., S. Kleinknecht, H.J. Nelde, and W.L. Strohmaier. Tumor necrosis factor in benign and malign tissue of the kidney. Urol. Res. 1991:19:367-373. 



\section{Chapter 7}

\section{TISSUE DISTRIBUTION AND CLEARANCE OF SOLUBLE MURINE TNF RECEPTORS IN MICE}

M.H.A. Bemelmans, D.J. Gouma, W.A. Buurman.

Submitted 


\section{Abstract}

In this study, clearance of STNFR was investigated. The data show that bilateral nephrectomy results in an increase of the levels of both sTNFR after which a new steady state situation develops, suggesting that next to the kidneys also other organs are involved in clearing of STNFR. Bilateral nephrectomy also leads to an increase in circulating TNF. This TNF was detected by ELISA and appeared to be not biologically active.

To investigate whether the endotoxin induced increase in STNFR is dependent of renal function, endotoxin was injected in nephrectomized mice. The data show that nephrectomy followed by endotoxin injection resulted in a further increase of the levels of both sTNFR. However, the endotoxin induced increase in nephrectomized mice was similar to the situation in normal mice after LPS indicating that the endotoxin induced increase is kidney independent in these mice.

To investigate the relative participation of various organs in sTNFR clearance, ${ }^{125} \mathrm{I}$ labelled sTNFR-P75 was injected. The data reveal that the majority of the sTNFR is removed from the circulation by the kidneys although also indications for involvement of the liver and the lungs were obtained. Calculation of the parametric clearance revealed that nephrectomy resulted in a 50\% reduction of sTNFR-P75 clearance.

Furthermore, the data presented strongly suggest that sTNFR release seems to be a continuous process, which is in balance with clearance of the sTNFR by the kidney, although also other organs such as the liver and the lungs are involved.

\section{Introduction}

Two different TNF receptors (TNFR-P55 and TNFR-P75) are reported to be present on the cell membrane (1-6). These TNFR can be liberated in vitro from the cell membrane of PMN's by proteolytic cleavage after stimulation with FMLP leading to the formation of a soluble form of TNFR (sTNFR)(7-11). Levels of sTNFR, like those of systemic TNF, increase in response to endotoxemia in vivo (12-14). In contrast to TNF, sTNFR levels are also detectable in normal situations in man as well as in animals $(12,15,16)$. While levels of sTNFR-P55 and sTNFR-P75 in man are similar, these levels differ considerably in mice (12). The murine sTNFR-P75 levels are in the same range as sTNFR-P75 levels in man (approximately $5 \mathrm{ng} / \mathrm{ml}$ ), while sTNFR-P55 levels are much lower in mice (approximately $75 \mathrm{pg} / \mathrm{ml}$ ). Moreover, the kinetics of both sTNFR in mice after LPS injection is clearly different. While sTNFR-P55 reveal a peak after $30 \mathrm{~min}$ and return rapidly to normal levels, sTNFR-P75 levels peak after 4-8 hours and remain elevated for several hours.

The observation that sTNFR-P75 levels in mice are much higher than sTNFR-P55 levels and remain in the circulation for a longer period of time, fit with previously reported data, that suggested that sTNFR-P75 is responsible for inactivation and subsequent clearance of TNF by the kidneys in mice (17). 
The fact that sTNFR were found in the urine of healthy individuals $(4,8,18-20)$ and enhanced levels of sTNFR were observed in plasma of patients with chronic renal failure (21), lead to the conclusion that sTNFR are cleared by the kidney.

In this study, the role of the kidney in the clearance of sTNFR was investigated using bilateral nephrectomy in a mouse model.

\section{Materials and methods}

Animals. Female Swiss mice weighing 27.5-34.5 grams were obtained from Charles River Breeding Laboratories (Heidelberg, FRG). They were maintained on a standard laboratory diet and were allowed free access to water. University of Limburg criteria for care and use of laboratory animals in research were followed throughout.

Reagents. Lipopolysaccharide E.coli O55:B5 (LPS), phenol extract (catalog no. L2880), Bovine Serum Albumin (BSA), 3-[4,5-dimethylthiazol-2-yl]-2,5 diphenyltetrazolium bromide (MTT), N,N-dimethyl formamide (DMF) were obtained from Sigma (St. Louis, MO); 3, 3',5, 5'-tetramethylbenzidine (TMB) was obtained from Kirkegaard \& Perry Laboratories Inc. (Gaithersburg, Maryland). TN3 (22), a hamster monoclonal antibody specific for murine TNF was a generous gift from Celltech, Slough, UK. Sodium dodecyl sulfate (SDS) was obtained from Bio-Rad (Richmond, CA). Peroxidase conjugated goat anti rabbit IgG was obtained from Jackson (Westgrove, PA). Polyclonal rabbit anti-murine TNF antiserum (RAMT) was produced by injecting rabbits with murine TNF kindly provided by Knoll/BASF (Ludwigshafen,FRG). Rabbit antibodies to soluble murine TNFR-P55 and P75, used in the ELISA were produced by injecting rabbits with highly purified murine TNFR-P55 and TNFR-P75, which were kindly provided by Prof M. Feldman (London, UK) and Prof. W. Fiers (Gent, Belgium).

Surgical Procedures. Mice were operated under a light ether anesthesia on a temperature controlled mattress. The mice were divided randomly into two groups: a sham operated control group and a group, in which both kidneys were removed (BN=bilateral nephrectomy). After making a midline abdominal incision, the vessel pedicles of the kidneys were identified, the kidneys were dissected from their surrounding tissue and ligatures were placed around the vessel pedicles of the kidneys. After this procedure, the ligatures were removed in the sham group, while in the BN group ligatures were tied and the kidneys were removed. Special care was taken to prevent damage to the adrenal blood supply, as was published previously (17).

Kinetics of sTNFR in nephrectomized mice. Role of the kidney in clearance of sTNFR was investigated in two sets of experiments. First in bilaterally nephrectomized (BN) mice with sham operated animals as controls and secondly in $\mathrm{BN}$ mice treated with LPS. 
In the first group, mice were randomly divided in two groups of 10 mice that were either subjected to BN or to a sham operation. Subsequently, the mice were divided in 2 groups of 5 mice. in the first group blood was sampled after $0.5,4$, and $12 \mathrm{hr}$ and in the second group after 1,2 , and $8 \mathrm{hr}$. Soluble TNF receptors were measured by ELISA, while TNF was measured by bioassay and ELISA.

In the second group ( 24 mice), a BN operation was performed and 90 minutes after operation $50 \mu \mathrm{g}$ LPS was injected ip. The mice were divided in 6 groups of 4 mice. In each group one blood sampling was done after which the mice were sacrificed. Blood was sampled after $0.5,1,2,4,8,12$ hours and sTNFR and TNF was measured.

Kinetics of ${ }^{125} 1$-murine sTNFR-P75 in normal and nephrectomized mice. Murine STNFR-P75 were labelled with ${ }^{125}$ I with a specific activity of $2 \mathrm{mCi}$ using Iodobeads (Pierce, Rockford, IL). Kinetics of ${ }^{125} \mathrm{I}$-murine sTNFR-P75 was studied by injection of $50 \mu \mathrm{l}(145.000 \mathrm{cpm})$ into the orbital plexus and blood was sampled out of the opposite orbital plexus. At the end of the experiment, mice were exsanguinated and the following organs or tissues were excised: liver, lung, spleen, kidneys, bladder, gallbladder, part of the abdominal section of the skin (including hair), heart, and thyroid. Furthermore, the urine was collected.

In the first set of experiments, kinetics of labelled sTNFR-P75 was studied in normal mice. Six mice were divided in two groups of three mice. In the first group, blood was sampled 10,30, and 60 minutes after injection of the radiolabelled protein and in the second group after 60,120,240, and 300 minutes. At the last timepoint, $60 \mathrm{~min}$ and $300 \mathrm{~min}$ respectively, mice were exsanguinated and the organs as mentioned in the surgical procedures section were excised. Thereafter, the tissues were weighed and radioactivity measured in a $\gamma$-counter. The same procedure was followed for the blood samples.

In the second set of experiments, the influence of nephrectomy on sTNFR-P75 kinetics was studied. $B N(n=6)$ or sham operation $(n=6)$ was performed and 90 min after the operation $50 \mu \mathrm{I}^{125} \mathrm{I}-\mathrm{sTNFR}-\mathrm{P} 75$ was injected. BN mice were divided in 3 groups of 2 mice. In group 1, mice were sacrificed after $10 \mathrm{~min}$, blood was collected and organs were excised. In group 2, blood was collected after 10 and $120 \mathrm{~min}$. In group 3 , blood was sampled after 60 and $240 \mathrm{~min}$. After the second blood sampling, $120 \mathrm{~min}$ in group 2 and $240 \mathrm{~min}$ in group 3 , mice were sacrificed and organs were excised. The same experimental protocol was followed for the 6 sham operated mice.

To check whether the labelled protein remained intact in the circulation, proteins in whole blood were precipitated using 50\% TCA solution, and radioactivity in the precipitate and the supernatant was compared. The data reveal that more than $75 \%$ of the radioactivity is found in the precipitate (protein bound) after $10 \mathrm{~min}$ and this figure remained constant during the experiment. Also, radioactivity was measured in the plasma and in centrifuged erythrocytes. The data indicate that the radioactivity is predominantly $(75 \%)$ present in the plasma and that the distribution rate plasma / erythrocyte does not change during the experiment. Moreover, the low radioactivity 
detected in the thyroid did not indicate that considerable amounts of free ${ }^{125} \mathrm{I}$ were present in the circulation (Table 1 and 2).

SDS-Page gel electrophoresis. Blood, bile acid and urine samples of sham operated mice collected $120 \mathrm{~min}$ after injection with ${ }^{125} \mathrm{I}$-sTNFR-P75, were run under reducing conditions using SDS-Phastgel Gradient (10 to 15\%) on a Phast system (Pharmacia, Uppsala, Sweden). As controls, two concentrations of murine ${ }^{125}$ I-sTNFR-P75 were run under reducing conditions. For autoradiography of the gels, Kodak XAR-5 film was used in combination with intensifier screens.

Enzyme linked imminosorbent assay (ELISA) for murine TNF. ELISA for murine TNF was performed as described earlier by Dentener (23). In short: A 96-well immuno maxisorp plate (Nunc, Roskilde, Denmark) was coated with TN3. Aspecific binding was blocked with BSA. After washings, $100 \mu \mathrm{l}$ diluted serum sample $(50 \mu \mathrm{l}$ serum/ 50 $\mu \mathrm{l}$ PBS) was added to each well. A standard titration curve was obtained by making a serial dilution of a known sample of murine recombinant TNF in normal murine serum. Subsequently, plates were washed and incubated with a polyclonal rabbit antimurine TNF antiserum followed by a peroxidase conjugated goat anti rabbit $\operatorname{lgG}$ and substrate TMB, activated with $\mathrm{H}_{2} \mathrm{O}_{2}$. The reaction was stopped and optical density was read. The ELISA has a lower detection limit of $50 \mathrm{pg} / \mathrm{ml}$ TNF.

WEHI 164 cytotoxicity bioassay. Biological TNF activity was measured using the murine fibrosarcoma WEHI 164 cell line $(24,25)$. The MTT-method was used to assess cell killing as described previously (26). A standard titration curve was obtained by making a serial dilution of a known quantity of a murine rTNF sample. The dilution giving rise to $50 \%$ lysis was correlated to the $\mathrm{LD}_{50}$ of the standard curve. $\mathrm{LD}_{50}$ ranged between 10 and $40 \mathrm{pg} / \mathrm{ml}$.

Enzyme linked immunosorbent assay for soluble murine soluble TNF-Receptors. ELISA for murine sTNFR was performed as described earlier (12). In short: a 96 well immuno-maxisorp plate (Nunc, Roskilde, Denmark) was coated with rabbit anti-soluble murine TNFR-P55 or rabbit anti-soluble murine TNFR-P75, resp. A standard titration curve was obtained by making a serial dilution of a known sample of recombinant murine TNFR-P55 or TNFR-P75, resp. Subsequently, plates were washed and incubated with biotinylated polycional rabbit anti-soluble mTNFR-P55 or anti-soluble mTNFR-P75. After washings, plates were incubated with streptavidin peroxidase followed by enzyme reaction. The detection limit for murine sTNFR-P55 is $5 \mathrm{pg} / \mathrm{ml}$ and for sTNFR-P75 $50 \mathrm{pg} / \mathrm{ml}$.

Statistical analysis. Differences in serum TNF and sTNFR levels were calculated using analysis of variance (27). Data are expressed as means \pm SEM unless stated otherwise. Probability values below 0.05 were considered to be statistically significant. 


\section{Results}

The effect of bilateral nephrectomy (BN) on sTNFR serum levels was studied in otherwise normal mice. The results show that levels of both sTNFR increased rapidly after BN, which was in contrast to sTNFR levels after sham operation ( $p<0.001$; Fig. 1). Already a few minutes after BN, an increase in both STNFR levels was observed and this increase held on for approximately $2-4$ hours after which the incline gradually diminished and sTNFR levels reached plateau levels after approximately 8 hours. In sham operated mice, a minor increase in both STNFR was observed as a result of the operation, which decreased after approximately $1 \mathrm{hr}$ (Fig. 1). Moreover, unilateral nephrectomy resulted in data that were comparable with the results obtained after sham operation (data not shown).

A

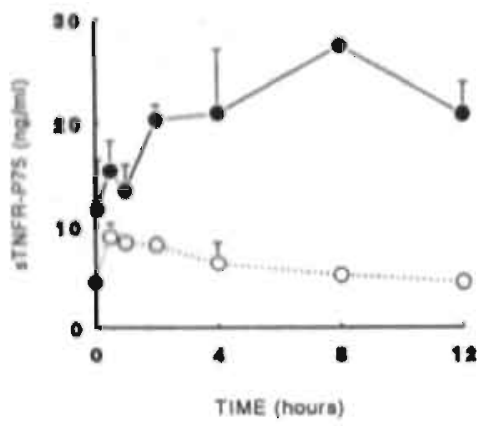

B

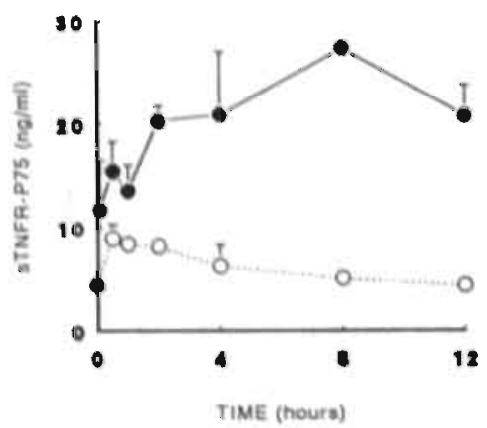

Fisure 2: BN leads to enhanced levels of TNF detectable by ELISA. Closed circles represent TTVF levels after BN $(n=10)$, open circles after sham operation $(n=10)$. The data obtained after WEHI assay were all below detection limit and therefore not shown. Data are expressed as means \pm SEM.
Figure 1: Levels of sTNFR increase rapidly after bilateral nephrectomy (BN). Closed circles represent sTNFR levels after BN $(n=10)$, open circles represent sTNFR levels after sham operation ( $\mathrm{n}=10)$ as measured by ELISA. Blood was collected $0.5,1,2,4,8$, and $12 \mathrm{hr}$ after operation. 8 TNFR-P55 levels are represented, by solid lines in upper graph $\mathrm{A}$, while sTNFR-P75 levels are represented by dashed fines in lower graph B. Data are expressed as means \pm SEM.

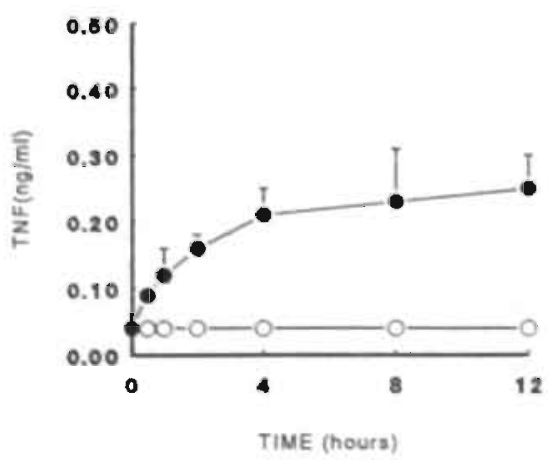


In the same serum samples, TNF levels were assessed by ELISA and by bio-assay. In contrast to sTNFR levels which reached plateau levels approximately 4 hours after BN, TNF levels measured by ELISA showed a steady increase during the experimental period (Fig. 2). Although the increase in TNF levels seems to diminish after 4-8 hr, previously published data showed that TNF levels after nephrectomy do not reach plateau levels, but remain rising (17). The detected TNF was found to be not biologically active as established by WEHI bioassay (data not shown). TNF levels in sham operated mice were below detection limit with the ELISA as well as with the bioassay (data not shown).

It has previously been shown that sTNFR levels increase rapidly after LPS administration in man and mice $(12,15,28)$. In order to investigate whether the LPS induced increase is independent of renal function, the effect of LPS administration on STNFR levels in BN mice was investigated. BN followed by LPS administration resulted in a rapid increase in STNFR levels which showed similar kinetics as after BN without endotoxin administration, reaching a plateau level after 2-4 hr (Fig. 3). However, maximal levels reached are much higher in these mice with maximal levels of sTNFRP55 of $9 \mathrm{ng} / \mathrm{ml}$ and of $70 \mathrm{ng} / \mathrm{ml}$ of sTNFR-P75 8 hours after nephrectomy and LPS injection $(\mathrm{p}<0.001)$.

Figure 3: LPS enhances sTNFR levels in BN mice. LPS $(50 \mu \mathrm{g})$ was administered to 24 mice and blood was collected $0.5,1,2,4,8$, and $12 \mathrm{hr}$ after LPS injection. sTNFR-P55 levels are represented by solid lines and open circles while sTNFR-P75 levels are represented by dashed lines and closed circles. Data are expressed as means \pm SEM

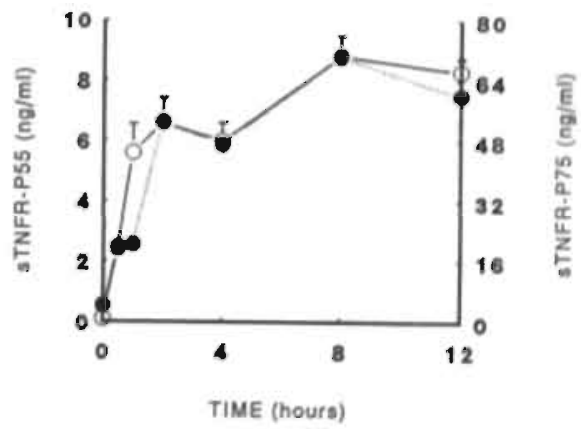

Clearance of sTNFR was studied in mice injected with murine sTNFR-P75 labelied with ${ }^{125}$ I. For these experiments, sTNFR-P75 was chosen because this receptor was considered to be responsible for TNF inactivation in mice (17). The data obtained show that after an initial peak after injection, sTNFR-P75 levels decreased slowly (Fig.4). 


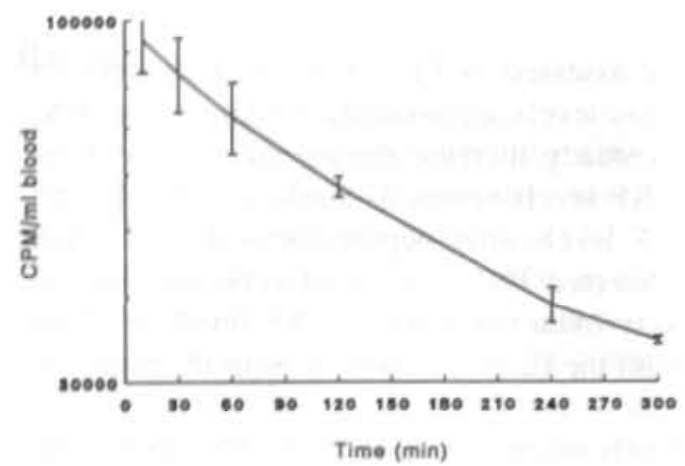

Figure 4: Kinetics of injected 12 I labelled. sTNFR-P75 injected in six mice. The solid line represents the label in $\mathrm{cpm} / \mathrm{ml}$ blood. Data are expressed as means \pm SEM.

Sixty min. after injection, highest radioactivity (expressed in absolute cpm) was observed in urine followed by liver, kidney and lung (Table 1). When expressed in $\mathrm{cpm} / \mathrm{mg}$ tissue (or $\mathrm{cpm} / \mathrm{mg}$ urine) highest counts were observed in urine, followed by bile, kidney, and thereafter the other organs (Table 1). The distribution pattern, observed after $120 \mathrm{~min}$. was similar to the situation after 60 minutes, although due to the clearance, the total amount of radioactivity per organ had diminished considerably (Table 1). To ascertain that the amount of sTNFR injected did not surpass the maximal clearance capacity in a next experiment $50 \%$ of the original amount of sTNFR-P75 was injected. The kinetics of the clearance data obtained were similar to the clearance data obtained with the higher amount of the receptor, which justifies the amount of receptor used in the above mentioned experiments (data not shown).

Table 1: Organ distribution of radioactivity in individual organs after injection of ${ }^{125} \mathrm{I}$ labelled sTNFRP75 in untreated mice at different time points.

$$
\mathrm{T}=60 \mathrm{~min}
$$

$\mathrm{T}=120 \mathrm{~min}$

\begin{tabular}{l|c|c|c|c} 
& \multicolumn{1}{|c}{ value/organ } & \multicolumn{1}{c}{$\mathrm{cpm} / \mathrm{mg}$ organ } & \multicolumn{1}{c}{ value/organ } & $\mathrm{cpm} / \mathrm{mg}$ organ \\
\hline Liver & $10,002 \pm 704^{\circ}$ & $6.6 \pm 0.5$ & $4,900 \pm 201$ & $3.9 \pm 0.09$ \\
\hline Bile & $921 \pm 142$ & $26.3 \pm 3.6$ & $712 \pm 140$ & $14.1 \pm 0.9$ \\
\hline Spleen & $774 \pm 114$ & $6.6 \pm 0.6$ & $259 \pm 29$ & $2.5 \pm 0.03$ \\
\hline Kidneys & $5,523 \pm 169$ & $13 \pm 1$ & $2,303 \pm 226$ & $6.3 \pm 0.5$ \\
\hline Bladder & $118 \pm 43$ & $6.1 \pm 1.3$ & $71 \pm 19$ & $4.7 \pm 0.9$ \\
\hline Urine & $24,497 \pm 9,655$ & $779 \pm 179$ & $3,369 \pm 545$ & $116 \pm 3.7$ \\
\hline Skin & $1,167 \pm 44$ & $5.8 \pm 0.7$ & $546 \pm 27$ & $2.4 \pm 0.04$ \\
\hline Heart & $761 \pm 44$ & $4.6 \pm 0.1$ & $470 \pm 122$ & $2.8 \pm 0.4$ \\
\hline Thyroid & $129 \pm 10$ & $7.6 \pm 0.9$ & $128 \pm 21$ & $5.7 \pm 1.6$ \\
\hline Lungs & $1,753 \pm 85$ & $8.6 \pm 0.8$ & $741 \pm 61$ & $3.5 \pm 0.2$
\end{tabular}

Data are expressed as means \pm SEM. 
To further unravel the role of the kidney in sTNFR clearance, labelled sTNFR-P75 were injected in $\mathrm{BN}$ and sham operated mice. The results reveal that $10 \mathrm{~min}$ after injection significantly higher levels of radioactivity were detected in the serum of BN mice compared to sham operated mice (Fig 5). This difference is maintained up to the end of the experiment after $240 \mathrm{~min}$. In contrast, the organ distribution was similar between $\mathrm{BN}$ and sham operated mice $10 \mathrm{~min}$ after injection of the labelled protein (data not shown). At later timepoints, $120 \mathrm{~min}$ and $240 \mathrm{~min}$, the liver and lung in BN mice reveal higher $\mathrm{cpm} / \mathrm{gram}$ tissue values compared to sham mice, suggesting that these organs are "activated" by the high serum receptor levels and compensate for the absence of the kidneys (Table 2).

Table 2: Radioactivity in individual organs after injection of ${ }^{125} \mathrm{I}$ labelled sTNFR-P75 in BN or sham operated mice after 120 and $240 \mathrm{~min}$.

\begin{tabular}{|c|c|c|c|c|c|c|c|c|}
\hline & \multicolumn{2}{|c|}{ SHAM (T= $120 \mathrm{~min})$} & \multicolumn{2}{|c|}{$B N(T=120 \mathrm{~min})$} & \multicolumn{2}{|c|}{ SHAM (T=240 min) } & \multicolumn{2}{|c|}{$\mathrm{BN}(\mathrm{T}=240 \mathrm{~min})$} \\
\hline & cpmvorgan & cpm/mg & cpm/organ & $\mathrm{cpm} / \mathrm{mg}$ & cpm/organ & $\mathrm{cpm} / \mathrm{mg}$ & cpm/organ & cpm/mg \\
\hline Liver & $4,161 \pm 1,804^{4}$ & $3.2 \pm 1.5$ & $4.519 \pm 145$ & $3.4 \pm 0.1$ & $4,967 \pm 871$ & $3 \pm 0.5$ & $10,830 \pm 929$ & $7.1 \pm 0.04$ \\
\hline Bile & $287 \pm 21$ & $20.9 \pm 0.7$ & $327 \pm 227$ & $31.3 \pm 2.9$ & $425 \pm 35$ & $14.6 \pm 2.9$ & $361 \pm 289$ & $21.7 \pm 13.9$ \\
\hline Spleen & $385 \pm 59$ & $2.8 \pm 0.04$ & $362 \pm 22$ & $3.8 \pm 0.3$ & $261 \pm 57$ & $1.9 \pm 0.3$ & $295 \pm 82$ & $2.5 \pm 0.6$ \\
\hline Kidneys & $2.551 \pm 59$ & $6.7 \pm 2.8$ & $\ldots$ & $\ldots$ & $2.017 \pm 298$ & $5 \pm 0.6$ & $\ldots$ & $\ldots$ \\
\hline Bladder: & {$[49 \pm 9$} & $5.6 \pm 0.3$ & -.. & - & $170 \pm 109$ & $6.9 \pm 4.1$ & $\ldots$ & $\ldots$ \\
\hline Urine & $14,930 \pm 1,630$ & $543 \pm 116$ & - & $\ldots$ & $6,386 \pm 4413$ & $201 \pm 3.6$ & $\cdots$ & + \\
\hline Skin & $1,571 \pm 167$ & $4.7 \pm 1$ & $2,150 \pm 161$ & $6.3 \pm 0.2$ & $631 \pm 125$ & $1.7 \pm 0.4$ & $1.345 \pm 589$ & $4 \pm 1.2$ \\
\hline Heart & $776 \pm 11$ & $4.4 \pm 0.4$ & $751 \pm 58$ & $5.3 \pm 0.3$ & $345 \pm 98$ & $2.1 \pm 0.5$ & $791 \pm 163$ & $4.9 \pm 0.5$ \\
\hline Thyroid & $18 i \pm 66$ & $7.5 \pm 0.8$ & $154 \pm 45$ & $6.6 \pm 0.7$ & $126 \pm 61$ & $4.7 \pm 3.6$ & $341 \pm 117$ & $8.9 \pm 2.1$ \\
\hline Langs & $839 \pm 285$ & $4.1 \pm 1.3$ & $804 \pm 28$ & $3.9 \pm 0.05$ & $703 \pm 20$ & $2.9 \pm 0.01$ & $2,127 \pm 382$ & $9.1 \pm 1.4$ \\
\hline
\end{tabular}

-Data are expressed as means \pm SEM. 


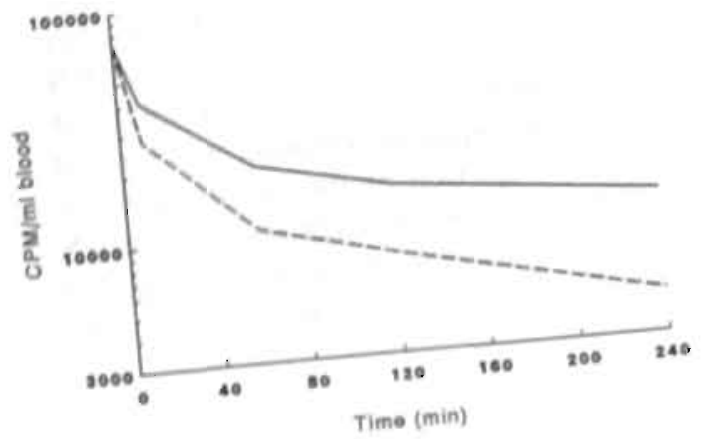

Figure 5: Kinetics of ${ }^{125}$ I labelled sTNFR-P75 Figure 5: Kinetics of and sham operated mice.
injected in BN mice an solid line represents the disappearance of
The the label from the circulation of BN mice $(n=6)$, the dashed line represents sTNFR levels in sham mice $(\mathrm{n}=6)$ (expressed in $\mathrm{cpm} / \mathrm{ml}$ blood). Data are expressed as means.

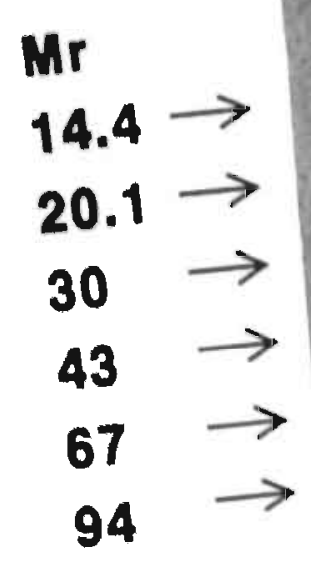

\section{A $B$ B C}

Fisure 6: SDS-PAGE of blood samples, urine samples and bile samples collected $120 \mathrm{~min}$ after injection of the labelled sTNFR-P75 in sham operaled mice. The sand $\mathrm{A}$ and $\mathrm{B}$ : murine ${ }^{125} \mathrm{I}-\mathrm{s}$ TNFR-P75 controls; SDS-PAGE and visualized by using autoradiography. 125 injected BN mice; lane E: bile. The positions lane $\mathrm{C}$ : urine: lane D: blood of murine
of the molecular mass standards are indicated (left). 
In order to investigate the molecular nature of the radioactivity detected in urine, blood, and bile, samples collected from sham operated mice $120 \mathrm{~min}$ after injection of labelled sTNFR-P75 were subjected to SDS-Page. The results show that the radioactivity recovered from the urine consists in part of intact labelled receptor (Fig.6), whereas a considerable amount of the radioactivity in the urine consists of products with very low molecular weight $(<5 \mathrm{Kd})$. These products most likely represent tyrosine residues coupled to iodine or free iodine which is released after catabolism of sTNFR in the kidney. The blood and bile samples did not contain enough radioactivity to be visualized by SDS-Page radiography. The fact that the thyroid does not demonstrate significant amounts of radioactivity at above mentioned timepoints together with the TCA precipitation data suggests low breakdown of labelled protein in the circulation. Estimation of the area under the curve (AUC) after injection of labelled sTNFR-P75 in $\mathrm{BN}$ and sham operated mice shows a clear difference between the $\mathrm{AUC}_{0-}$ of $\mathrm{BN}$ mice and the $\mathrm{AUC}_{0-}$ of sham operated mice (Table 3). Moreover, the data show that the parametric clearance (CL: Dose/ $\left.\mathrm{AUC}_{0-\infty}\right)$ is strongly reduced in $\mathrm{BN}$ mice compared to sham mice $(0.99 \mathrm{ml} / \mathrm{hr}$ vs $2.13 \mathrm{ml} / \mathrm{hr}$; Table 3$)$.

Table 3: Estimation of the area under the curve (AUC) after injection of labelled sTNFR-P75 in BN $(n=6)$ and sham operated mice $(n=6)$ and the subsequent parametric clearance ${ }^{6}$.

$$
\mathrm{AUC}_{\mathrm{lm}}(\mathrm{cpm} \cdot \mathrm{hr} / \mathrm{ml}) \quad \mathrm{Cl}(\mathrm{ml} / \mathrm{hr})
$$

\begin{tabular}{lll}
\hline BN Mice & 145,980 & 0.99
\end{tabular}

$\begin{array}{lll}\text { Sham mice } & 66,975 & 2.17\end{array}$

"Parametric clearance (CL) is expressed as dose/AUC

\section{Discussion}

The data show that the kidney plays an important role in clearance of both s TNFR-P55 and sTNFR-P75. The rapid increase in both sTNFR levels after BN is in contrast to the kinetics of sTNFR levels after sham operation or unilateral nephrectomy. The latter treatments caused only a minor, short living increase, most likely as a result of the trauma, a phenomenon which has been described earlier (29). Moreover, in vitro data show that even hypoxia can induce sTNFR release (30). Under normal physiological conditions, these sTNFR are primarily cleared by the kidneys which results in a steady state level of approximately $50 \mathrm{pg} / \mathrm{ml}$ sTNFR-P55 and $5 \mathrm{ng} / \mathrm{ml}$ sTNFR-P75 in the circulation in mice (12). 
Several hours after BN, a new equilibrium of sTNFR levels is formed as reflected by the plateau levels of sTNFR in the serum. However, this equilibrium is reached at the cost of increased circulating sTNFR levels.

Taken together, the data strongly suggest that a continuous production of sTNFR occurs which are released in to the circulation. Whether these sTNFR are enzymatically cleaved membrane TNF-R (the so-called shedding) or produced by alternative splicing remains to be resolved.

The sTNF-R clearance, for which the kidney appears to be most important leads in normal mice to the stable plasma levels mentioned above. In absence of the kidneys, organs with a substantially lower extraction fraction are responsible for the clearance leading to much higher plasma levels of both STNFR. Whether in nephrectomized animals the continuous production of sTNFR is changed compared to normal animals remains to be resolved.

LPS in BN animals caused a similar rapid increase in sTNFR levels as it does in normal mice indicating that the kidney is not involved in the LPS induced increase in sTNFR levels. In BN mice, the LPS enhanced production of sTNFR results in a further delayed reaching of the equilibrium and thus higher plasma levels of sTNFR at the moment the equilibrium is reached.

The experiments with labelied sTNFR reveal that 1 hour after injection in terms of cpm per mg of organ/tissue, the highest radioactivity was found in the urine, followed by the gallbladder and the kidneys, which supports a major role for the kidneys and also a role for the liver. The data are at variance with the data of Gascon et al. who investigate the kinetics of exogenous human sTNFR in mice. Human sTNFR tend to accumulate more in the bile than murine sTNFR (31), which may represent in part foreign protein clearance by the liver.

Furthermore, the data suggest that the $t_{1 / 2}$ of labelled sTNFR-P75 is shorter in sham operated mice than in normal non treated mice. A possible explanation is that the operation results in an activated state of the organs responsible for clearance of STNFR-P75 resulting in a more rapid removal from the circulation. The definitive explanation for this fact remains however unclear.

Our results are in line with the hypothesis that under normal physiological conditions STNFR are being cleared from the circulation by the kidneys. $(12,21)$. In addition, the SDS-PAGE data reveal that part of the radioactivity present in the urine is coming from intact sTNFR, suggesting that the sTNFR protein can pass the glomerular filter of the kidney. The latter data is supported by the data of others, who reported the presence of functional sTNFR in human urine $(4,18,19)$.

The results obtained after calculation of the parametric clearance further support the hypothesis that the kidney is an important organ for clearance of the sTNFR, although other organs are also involved. Their role in presence of normal functioning kidneys remains nevertheless to be established.

Based on our results and our previous studies, we propose that a continuous production of sTNFR and a relatively rapid clearance of sTNFR and also of sTNFR-TNF com- 
plexes is an important mechanism in the physiological protection against the harmful effects of circulating TNF. Such TNF may be leaking from local inflammatory sites. This is in line with early reports showing that the STNFR function as anticytokines which are responsible for binding and inactivation of TNF (1,32-36). Our hypothesis differs from that of Aderka et al., who suggest that the sTNFR-TNF complexes form slow release reservoirs (37), which was based on the in vitro observation that sTNFR stabilizes TNF in vitro.

In conclusion, it is suggested that a continuous release of sTNFR occurs in balance with renal function, which also explains the strongly enhanced sTNFR levels in anuric patients. Therefore, measurement of sTNFR in clinical situations should be related to kidney function. In line with the important function of the kidney in sTNFR clearance, Froon et al. described recently that sTNFR levels in septic patients strongly correlated with renal function (38), making correlation with other parameters complicated. 


\section{References}

1. Fiers, W. Tumor Necrosis Factor, characterization at the molecular, cellular and in vivo level. FEBS. Lett. 1991;285:199-212.

2. Tartaglia, L.A.,D.V. Goeddel. Two TNF receptors. Immunol. Today 1992;13:151-153.

3. Dembic, Z., H. Loetscher, U. Gubler, Y-CE. Pan, H-W. Lahm, R. Gentz, M. Brockhaus, W. Lesslauer. Two human TNF receptors have similar extracellular, but distinct intracellular, domain sequences. Cytokine 1990;2:231-237.

4. Engelmann, H., D. Novick, D. Wallach. Two tumor necrosis factor-binding proteins purified from human urine: evidence for immunological cross-reactivity with cell surface tumor necrosis factor receptors. J. Biol. Chem. 1990;265:1531-1536.

5. Hohmann, H.P., R. Remy, M. Brockhaus, A.P.G.M. van Loon. Two different cell types have different major receptors for human tumor necrosis factor (TNF $\alpha$ ). J. Biol. Chem. 1989;264: 14927.14934.

6. Nophar, Y., O. Kemper, C. Brakebush, H. Engelmann, R. Zwang. D. Aderka, H. Holtman, D. Wallach. Soluble forms of tumor necrosis factor receptors (TNF-Rs): the cDNA for the type 1 TNF-R, cloned using amino and sequence data of its soluble form, encodes both the cell surface and a soluble form of the receptor. EMBO J. 1990;9:3269-3278.

7. Ding. A.H., F. Porteu. Regulation of Tumor Necrosis Factor receptors on phagocytes. P. Soc. Exp. Biol. Med. 1992;200;458-465.

8. Lantz, M., U. Gullberg, E. Nilsson, I. Olsson. Characterization in vitro of a human tumor necrosis factor-binding protein. J. Clin. Invest. 1990;86:1396-1402.

9. Porteu, F., C. Natan. Shedding of tumor necrosis factor by activated human neutrophils. $J$. Exp. Med. 1990;172: 599-607.

10. Porteu, F., M. Birockhaus, D. Wallach, H. Engelmann, C. Nathan. Human neutrophil elastase releases a ligand-binding fragment from the $75-\mathrm{kDa}$ Tumor Necrosis Factor (TNF) receptor. J. Biol. Chem. 1991;266:18846-18853.

11. Lewis, M., L.A. Tartaglia, A. Lee, G.L. Bennet, G.C. Rice, G.H.W. Wong, E.Y. Chen, D.V. Goeddel. Cloning and expression of cDNAs for two distinct murine tumor necrosis factor receptors demonstrate one receptor is species specific. Proc. Natl. Acad. Sci. 1991;88:28302834

12. Beme!mans, M.H.A., D.J. Gouma, W.A. Buurman. LPS induced sTNF-Receptor release in vivo in a murine model: investigation of the role of TNF, IL-1, LIF, and IFN- $\gamma . J$. Immunol. 1993;151:5554-5562.

13. Shapiro, L., B.D. Clark, S.F. Orencole, D.D. Poutsiaka, E.V. Granowitz, C.A. Dinarello. Detection of Tumor Necrosis Factor soluble receptor p55 in blood samples from healthy and endotoxemic humans. J. Inf. Dis. 1993;167:1344-1350.

14. Seckinger, P., S. Isaaz, J.M. Dayer. A human inhibitor of tumor necrosis factor- $\alpha$. J. Exp. Med. 1988:167:1511-1516.

15. Van Zee, K.J., T, Kohno, E. Fischer, C.S. Rock, L.L. Moldawer, S.F. Lowry. Tumor Necrosis Factor soluble receptors circulate during exerimental and clinical inflammation and can protect against excessive Tumor Necrosis Factor $\alpha$ in vitro and in vivo. Proc, Natl. Acad. Sci. USA $1992,89: 4845-4849$.

16. Aderka, D., H. Engelmann, Y. Shemer-Avni, V. Hornik, A. Galil, B. Sarov, D. Wallach. Variation in serum levels of the soluble TNF receptors among healthy individuals. Lymphokine Res. 1992:11:157-159.

17. Bemelmans, M.H.A., D.J. Gouma, W.A. Buurman. Influence of nephrectomy on Tumor Necrosis Factor clearance in a murine model. J. Immunol. 1993:150:2007-2017. 
18. Olsson, I., M. Lantz, E. Nilsson, C. Peetre, H. Thyssell, A. Grubb, G. Adolf. Isolation and characterization of a Tumor Necrosis Factor binding protein from urine. Eur. J. Haematol. 1989:42:270-275.

19. Novick, D., H. Engelmann, D. Wallach. Purification of soluble cytokine receptors from normal human urine by ligand-affinity and immunoaffinity chromatography. J. Chromatogr. 1990:510:331-337.

20. Peetre, C., H. Thysell, A. Grubb, I. Olsson. A tumor necrosis factor binding protein is present in human biological fluids. Eur. J. Haematol. 1988;41:414-419.

21. Brockhaus, M., Y. Bar-Khayim, S. Gurwicz, A. Frensdorff, N. Haran. Plasma Tumor Necrosis Factor soluble receptors in chronic renal failure. Kidney Int, 1992,42:663-667.

22. Sheehan, K.C.F., N.H. Ruddle, R.D. Schreiber. Generation and characterization of hamster monoclonal antibodies that neutralize murine Tumor Necrosis Factors. J. Immunol. 1989;142: 3884-3893.

23. Dentener, M.A., J.W. Greve, J.G. Maessen, W.A. Buurman. Role of tumor necrosis factor in the phenomenon of the enhanced sensitivity of animals to endotoxin after exposure to lead. Immunoph. Immunotoxicol. 1989;11:321-324.

24. Rollinghoff, M., N.L. Warner. Specificity of in vivo tumor rejection assessed by mixing immune spleen cells with target and unrelated tumor cells. Proc. Soc. Exp. Biol. Med. $1973: 144: 813^{\prime}-818$.

25. Espevik, T., J. Nissen-Meyer. A highly sensitive cell line, WEHI 164 clone 13, for measuring cytotoxic factor /tumor necrosis factor from human monocytes. J. Immunol. Methods 1986;95:99-105.

26. Hanssen, M.B., S.E. Nielsen, K. Berg. Re-examination and further development of a precise and rapid dye method for measuring cell growth/cell kill. J. Immunol. Methods 1989;119:203. 210 .

27. Norusis, M.J.. ed. SPSS/PC+ V3.I Base Manual for the IBM PC/XT/AT and PS/2. SPSS Inc., 1988, Chicago, USA.

28. Spinas, G.A., U. Keller, M. Brockhaus. Release of soluble receptors for Tumor Necrosis Factor (TNF) in relation to circulating TNF during experimental endotoxemia. J. Clin. Invest. 1990;90:533-536.

29. Tan, L.R., K. Waxman, G. Scanell, G. Loli, G.A. Granger. Trauma causes early release of soluble receptors for Tumor Necrosis Factor. J. Trauma. 1993;34:634-638.

30. Scannell, G., K. Waxman, G.J. Kaml, G. Loli, T. Gatanaga, R. Yamamoto, G.A. Granger. Hypoxia induces a human macrophage cell line to release Tumor Necrosis Factor- $\alpha$ and its soluble receptors in vitro. J. Surg. Res. 1993;54:281-285.

31. Gascon, M-P., H.C. Porchet, J. le Cotonnec, A. Ythier, D. Wallach, P. Piguet, G.E. Grau. Pharmacokinetics and tissue distribution of human urinary tumor necrosis factor binding protein in mice. Drug. Met. Disp. 1992;20:592-595.

32. Olsson, T., U. Gatanaga, U. Gullberg, M. Lantz, G.A. Granger. Tumour necrosis factor (TNF) binding proteins (soluble TNF receptor forms) with possible roles in inflammation and malignancy. Eur. Cytokine Netw. 1993;4:169-180.

33. Bertini, R., R. Delgado, R. Faggioni, M. Gascon, A. Ythier, P. Ghezzi. Urinary TNF-binding protein (TNF soluble receptor) protects mice against the lethal effect of TNF and endotoxic shock. Eur. Cytokine Netw. 1993:4:39-42.

34. Lesslauer, W., H. Tabuchi, R. Gentz, M. Brockhaus, E.J. Schlaegger, G. Grau, P.F. Piguet, P. Pontaire, P. Vassali, H. Loetscher. Recombinant soluble Tumor Necrosis Factor receptor proteins protect mice from lipopolysaccharide-induced lethality. Eur. J. Immunol. 1991;21: 2883-2886. 
35. Ashkenazi, A., S.A. Marsters, D.J. Capon, S.M. Chamov, I.S. Figari, D. Pennica, D.V. Goeddel, M.A. Palladino, D.H. Smith. Protection against endotoxic shock by a Tumor Necrosis Factor receptor immunoadhesin. Proc. Natl. Acad. Sci. USA 1991;88:10535-10539.

36. Engelberts, L., S. Stevens, G.J.M. Francot, C.J. van der Linden, W.A. Buurman. Evidence for different effects of soluble TNF-receptors on various TNF measurements in human biological fluids. Lancet 1991:338:515-516.

37. Aderka, D., H. Engelmann, Y. Maor, C. Brakebush, D. Wallach. Stabilization of the bioactivity of Tumor Necrosis Factor by its soluble receptors. J. Exp. Med. 1992;175:323-329.

38. Froon, A.H.M., M.H.A. Bemelmans, J.W. Greve, C.J. van der Linden, W.A. Buurman. Increased plasma levels of soluble Tumor Necrosis Factor receptors in sepsis syndrome: correlation with plasma creatinine. Crit Care in press. 


\section{Chapter 8}

\section{LPS INDUCED STNF-RECEPTOR RELEASE IN VIVO IN A MURINE MODEL: INVESTIGATION OF THE ROLE OF TNF, IL-1, LIF, AND IFN- $\gamma_{\text {。 }}$}

M.H.A. Bemelmans, D.J. Gouma, W.A. Buurman.

J. Immunol. 1993;151:5554-5562. 


\begin{abstract}
Tumor Necrosis Factor (TNF), a primary mediator of the response to infection, can be injurious to the organism when present in excessive quantities. Circulating soluble TNF receptors appear to represent a natural mechanism that protects against circulating TNF. Two soluble TNF Receptors (sTNFR-P55 and sTNFR-P75) circulate in vivo and are upregulated in response to endotoxin. In this study, we investigated the kinetics of LPS induced sTNFR release and the role of the cytokines TNF, LIF, IFN- $\gamma$, and IL-1 in this process.
\end{abstract}

The results show that LPS injection results in a rapid increase in levels of both sTNFR. While sTNFR-P55 decreases after a peak at 30 minutes, sTNFR-P75 levels show a peak after 4-8 hours after which they slowly diminish. Both hTNF and mTNF are capable of increasing levels of both sTNFR. Blocking circulating TNF by administration of 3 different anti-TNF agents before LPS injection (monoclonal antibody to mTNF, sTNFR55-Fc or sTNFR75-Fc) results in a significant increase of sTNFR-P55 levels, while only both sTNFR-Fc constructs also significantly increase sTNFR-P75 levels. While IL-1 ra pretreatment before LPS has no effect on TNF or sTNFR levels, LIF pretreatment significantly increases sTNFR-P55 levels. Pretreatment with $\alpha$ IFN- $\gamma$ monoclonal antibody before LPS results in a significant reduction in TNF and sTNFRP55 levels while sTNFR-P75 levels are significantly increased.

Our data show that both sTNFR can be upregulated by LPS and TNF. The influence of TNF, LIF, IL-I and IFN- $\gamma$ on the kinetics of LPS induced circulating sTNF-R is discussed in the context of the pathophysiology of LPS induced disease.

\title{
Introduction
}

Two different TNF receptors have been identified, a $55 \mathrm{kD}$ receptor (TNFR-P55) and a $75 \mathrm{kD}$ receptor (TNFR-P75) (1-3). They appear to be present to different extent on the celi surface of various cells (4). The extracellular parts of both TNF receptors are found also as soluble TNF receptors (sTNFR) in circulation (5-7). TNF receptors were suggested to be part of a paracrine and autocrine regulatory system, which regulates the toxic effects of circulating TNF (8). On the one hand, liberation from the cell surface receptors by proteolytic cleavage of $\mathrm{TNF}$ receptors can protect against the deleterious effects of TNF by binding circulating TNF, whereas on the other hand, the loss of cell surface receptors can lead to a transiently decreased responsiveness to TNF. Recently we reported data that provided strong evidence that in mice sTNFR-P75 plays an important role in inactivation of TNF followed by clearance of TNF by the kidney (9).

In vitro data show, that FMLP, C5a, GM-CSF, and elastase cause shedding of TNFR from the cell surface of PMN's, whereas endotoxin, IFN- $\gamma$, IL-1B, or TGF-B1 do not cause shedding (10-12). However, few data are available about the mechanisms that are responsible for TNFR liberation in vivo. Increase of sTNF-R levels have been 
observed in the serum of febrile patients, in cancer patients, in patients with rheumatoid arthritis, and in patients with end stage renal disease (7, 13-16). Administration of Escherichia coli endotoxin to healthy human volunteers resulted in induction of significant amounts of sTNFR $(8,17)$. sTNFR-P75 peak levels correlated significantly with TNF levels, whereas sTNFR-P55 did not correlate with TNF. These data suggest a difference in regulation of both STNFR.

The current study was performed to investigate the mechanism, which underlies the increase in STNFR levels in response to LPS. In this process, the role of TNF and cytokines known to be involved in LPS induced pathophysiology, like IFN- $\gamma$, LIF (Dfactor) and IL-1 were studied.

\section{Materials and Methods}

Animals. Female Swiss mice weighing 27-34 grams were obtained from Charles River Breeding Laboratories (Heidelberg, FRG). They were maintained on a standard laboratory diet and were allowed free access to water.

Reagents. Lipopolysaccharide E.coli O55:B5 (LPS), phenol extract (catalog no. L2880), 3-[4,5-dimethylthiazol-2-yl]-2,5 diphenyltetrazolium bromide (MTT), N,N-dimethyl formamide (DMF), substrate O-Phenyl-Diamine (OPD) and Bovine Serum Albumin (BSA) were obtained from Sigma (St Louis, MO). Culture medium (CM) consisted of RPMI 1640 (Gibco, Paisley, U.K.) supplemented with $10 \%$ bovine calf serum (Hyclone, Logan, UT), penicillin $100 \mathrm{U} / \mathrm{ml}$ and streptomycin $100 \mu \mathrm{g} / \mathrm{ml}$ (Flow, Irvine, U.K.). Sodium dodecyl sulfate (SDS) was obtained from Bio-Rad (Richmond, CA). The mAb 61E71 $\left(\operatorname{IgG}_{1}\right)$, an anti TNF antibody that inhibited the biological function of TNF in both the L929 and the WEHI bioassay was described previously (18). Peroxidase conjugated goat anti rabbit IgG was obtained from Jackson, Westgrove, PA. Polyclonal rabbit anti-murine TNF antibodies (RaMT) and rabbit anti-human TNF antibodies were produced by injecting rabbits with murine or human TNF, iespectively. TN3 (19) is a hamster monoclonal antibody specific for murine TNF (kindly provided by Celltech Slough, UK). The following agents were obtained through the courtesy of the respective firms or persons: Recombinant human and murine TNF (kindly provided by BASF/Knoll, Ludwigshafen, FRG): D-factor (LIF), recombinant murine TNFR-P55 and TNFR-P75, and rabbit anti murine, sTNFR-P55 and P75 (kindly provided by Dr. D.V. Goeddel and Dr. G. Wong, Genentech, San Francisco, CA); Anti-MuIFN- $\gamma$ (F3, kindly provided by Dr. H. Heremans, Leuven, Belgium); I-1ra (kindly provided by Dr. J. Vannice, Synergen, Boulder, CO); sTNFR55-Fc, a TNF receptor construct (20) (kindly provided by Dr. Lesslauer and Dr. Loetscher, F. Hoffmann-La Roche Ltd., Basel, Switzerland); sTNFR75-Fc (kindly provided by Dr. S. Gillis, Immunex, Seattle, WA). 
Experimental protocol. Mice were injected ip with LPS $(10 \mu \mathrm{g} ; \mathrm{n}=48$ or $100 \mu \mathrm{g}$; $\mathrm{n}=12$ ), mTNF (250 ng; $\mathrm{n}=12$ ) or hTNF (250 ng; $\mathrm{n}=12$ ) dissolved in $500 \mu \mathrm{l}$ phosphate buffered saline (PBS). In the first experiment, kinetics of sTNFR-P55 and sTNFR-P75 after $10 \mu \mathrm{g}$ LPS were studied. Mice were randomized in 8 groups of 6 mice. Blood samples were taken after 0.5, 1, 1.5, 2, 4, 8, 12, 16 (Fig 1). At every time point, 200 $\mu \mathrm{l}$ blood of one group of mice was taken by orbital puncture under light ether anesthesia. After clotting for one hour at room temperature, blood was centrifugated, serum was collected and serum was frozen at $-20 \mathrm{C}$. After 24 hours, all mice were exsanguinated for endpoint values. Since peak levels of sTNFR-P55 were found after 0.5 hours and peak levels of sTNFR-P75 levels after 8 hours, in subsequent experiments blood was taken after $0.5,2,8$ and 24 hours after LPS or TNF injection. In every experimental group, mice were divided into two groups. In one group blood was collected after $0.5,8$ and 24 hours and in the other group after 2 and 24 hours. The results of these two groups were pooled.

In order to investigate the role of different cytokines in LPS induced increase of sTNFR plasma levels, the following treatments were combined with $10 \mu \mathrm{g}$ LPS administration: monoclonal anti-TNF antibody (TN3) at $\mathrm{t}=-6 \mathrm{~h}$ ip $(750 \mu \mathrm{g} / \mathrm{mouse}$ in 500 $\mu \mathrm{l}$ PBS; $\mathrm{n}=16$ vs 16 control LPS mice); sTNFR55-Fc ip at $\mathrm{t}=-2$ hours in $250 \mu \mathrm{l}$ PBS ( $25 \mu \mathrm{g} /$ mouse; $n=17$ vs 20 control LPS mice); sTNFR75-Fc ip at $t=-2$ hours in $250 \mu \mathrm{l}$ PBS ( $25 \mu \mathrm{g} /$ mouse; $\mathrm{n}=25$ vs 28 control LPS mice); a monoclonal anti-MUIFN- $\gamma$ antibody ip $(0.1 \mathrm{mg} /$ mouse in $500 \mu \mathrm{l} \mathrm{PBS})$ at $\mathrm{t}=-24$ hours ( $\mathrm{n}=19$ vs 21 control LPS mice); LIF (D-factor) $10 \mu \mathrm{g}$ per mouse in $0.5 \mathrm{ml}$ PBS ip at $\mathrm{t}=-24$ hours $(\mathrm{n}=26$ vs 29 control L.PS mice); IL-1ra $(0.5 \mathrm{mg} /$ mouse per injection, dissolved in $100 \mu \mathrm{l} 0.5 \% \mathrm{BSA}$ ) subcutaneously just before, and 4,8 , and 12 hours after LPS injection ( $\mathrm{n}=16$ vs 18 control LPS mice). The doses of the treatments used have been shown to be protective against lethal endotoxemia $(20,21-26)$. Moreover, administration of these reagents without LPS injection did not result in differences in TNF or STNFR levels (data not shown).

Enzyme linked immunosorbent assay for soluble murine TNF-Receptors. Antisera against soluble murine TNFR-P55 and P75 were raised in rabbits by injection of highly purified recombinant murine TNFR-P55 and TNFR.P75. Antibodies were purified by ammonium sulfate precipitation and Protein A chromatography. The antisera were titered by ELISA, with recombinant murine TNF receptors coated in the wells of microtiter plates. The titers were as follows: rabbit anti smTNFR-P55: titer to smTNFR-P55 1:200,000 and to smTNFR-P75 1:130. Rabbit anti smTNFR-P75: titer to smTNFR-P75 1:60,000 and to smTNFR-P55 1:160. These highly specific antibodies were used to coat 96-well immuno-maxisorp plates (Nunc, Roskilde, Denmark). A standard titration curve was obtained by making a serial dilution of a known sample of recombinant murine TNFR-P55 or TNFR-P75. Subsequently, plates were washed and incubated with biotinylated polyclonal rabbit anti soluble mTNFR-P55 or anti soluble mTNFR-P75. After washings, plates were incubated with streptavidin peroxi- 
dase followed by enzyme reaction. The detection limit in serum for murine sTNFR-P55 is $5 \mathrm{pg} / \mathrm{ml}$ and for sTNFR-P75 $50 \mathrm{pg} / \mathrm{ml}$. Spiking murine sTNFR with samples containing murine TNF, human TNF, human sTNFR55-Fc, or human sTNFR75-Fc did not influence the reading of the elisa for murine sTNFR (data not shown).

Enzyme linked immunosorbent assay for murine TNF. Elisa for murine TNF was performed as described earlier by Dentener (25). In short: A 96-well immuno maxisorp plate (Nunc, Roskilde, Denmark) was coated with TN3. A standard titration curve was obtained by making a serial dilution of a known sample of murine recombinant TNF (BASF) in 50\% normal murine serum. Subsequently, plates were washed and incubated with RaMT, followed by an enzyme labelled anti-rabbit reagent and enzyme reaction. The detection limit for murine TNF is $50 \mathrm{pg} / \mathrm{ml}$.

WEHI 164 cytotoxicity bioassay. Biological TNF activity was measured using the murine fibrosarcomal WEHI 164 cell line $(27,28)$. The MTT-method was used to assess cell killing as described previously (29). A standard titration curve was obtained by making a serial dilution of a known quantity of a murine ITNF sample. The dilution giving rise to $50 \%$ lysis was correlated to the $L D_{50}$ of the standard curve. $L D_{50}$ ranged between 10 and $40 \mathrm{pg} / \mathrm{ml}$.

Enzyme linked immunosorbent assay for human TNF. Elisa for human TNF was performed as described earlier by Engelberts (18). In short: A 96-well immuno maxisorp plate was coated with a murine anti-human TNF mAb 6ilE71. A standard titration curve was obtained by making a serial dilution of a known sample of human recombinant TNF in normal murine serum. The plates were incubated with a polyclonal rabbit anti-human-TNF antiserum, followed by an enzyme labelled anti-rabbit reagent and enzyme reaction. The detection limit for human TNF is $20 \mathrm{pg} / \mathrm{ml}$.

Statistical Analysis (30). Analysis of variance (ANOVA) was used for comparison of differences in serum TNF and TNFR levels after the different treatments followed by LPS or TNF injections. Probability (p) values below 0.05 were considered to be statistically significant.

\section{Results}

LPS injection $(10 \mu \mathrm{g} /$ mouse ip) resulted in a TNF peak level of $30 \mathrm{ng} / \mathrm{ml}$ after 90 minutes, which diminished rapidly (Fig 1A). At 4 hours, TNF was no longer detectable. A higher dose of LPS (100 $\mu \mathrm{g} /$ mouse) resulted in a further increase in circulating TNF, while the kinetics remained similar (Fig 2A). The levels detected by immunoassay and WEHI bioassay were similar (data not shown), showing that most of the detected TNF was biologically active. 
A

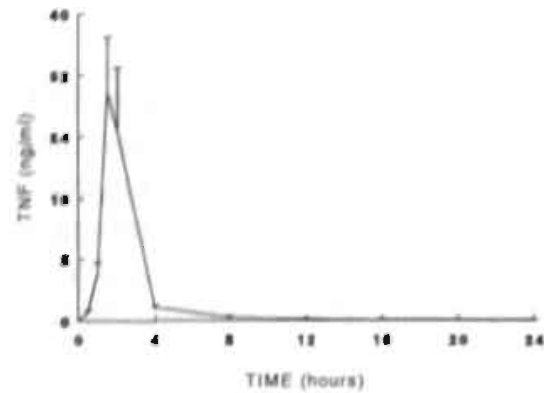

B

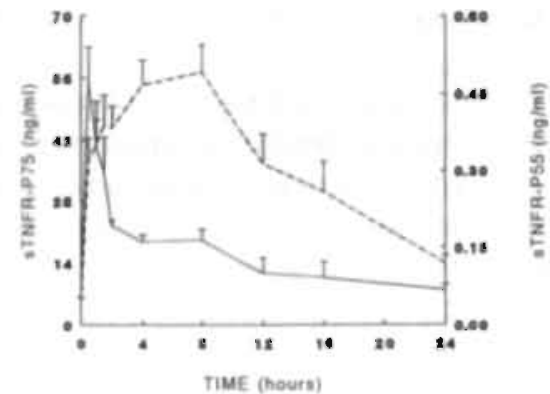

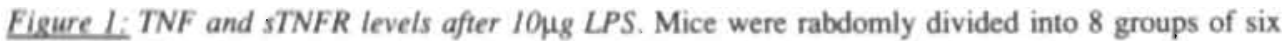
mice each. Blood was sampled at $0.5,1,1.5,1,4,8,12$ and 16 hours after the LPS injection. At every timepoint, $200 \mu \mathrm{l}$ blood of one group of mice was taken. After 24 hours all mice were exsanguinated.

(A) TNF levels after $10 \mu \mathrm{g}$ LPS ip.

(B) STNFR-P55 (solid line) and sTNFR-P75 levels (dashed line) after $10 \mu \mathrm{g}$ LPS ip. Data are expressed as means \pm SEM.

Whereas TNF is not detectable in serum of normal non treated mice, we detected 56 $\pm 18 \mathrm{pg} / \mathrm{ml}$ sTNFR-P55 and $5 \pm 0.7 \mathrm{ng} / \mathrm{ml}$ sTNFR.P75 in these mice. In the LPS ireated mice, we observed that a rapid increase of STNFR levels preceded measurable circulating TNF (Fig 1B). The kinetics of sTNFR-P55 and sTNFR-P75 differed substantially. sTNFR-P55 increased from baseline levels to a maximum from 350 $\mathrm{pg} / \mathrm{ml}$ as soon as 30 minutes after LPS injection. Thereafter sTNFR-P55 levels declined rapidly, although after 4 hours approximately 200 pg/ml sTNFR.P55 was still detectable. STNFR-P75 showed a similar rapid increase detectable as soon as 30 minutes after LPS injection. However, sTNFR-P75 levels increased from approximately $5 \mathrm{ng} / \mathrm{ml}$ to reach a maximum of approximately $50 \mathrm{ng} / \mathrm{ml}$ after $4-8$ hours. Thereafter, sTNFRP75 levels declined slowly. They remained elevated for a longer period of time, and after 16 hours still $30 \mathrm{ng} / \mathrm{ml}$ sTNFR-P75 was present. A higher dose of LPS (100 $\mu \mathrm{g})$ did not cause a further increase of sTNFR-P55, but resulted in slightly higher sTNFRP75 levels (Fig 2B/C).

To investigate whether TNF released in response to LPS is responsible for the shedding of TNF receptors, mice were injected with murine TNF. High levels of circulating TNF were present 30 minutes after injection (mean of $6 \mathrm{ng} / \mathrm{ml}$ ). TNF was no longer detectable after 2 hours (data not shown). While a minor increase in sTNFR-P55 with a peak after 30 minutes was seen, sTNFR-P75 increased rapidly till $25 \mathrm{ng} / \mathrm{ml}$ after 2 hours, and declined slowly afterwards (Fig 3A/B). 
A

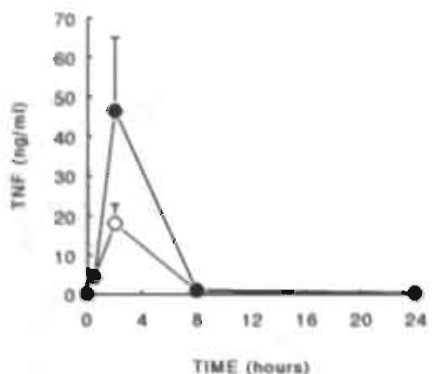

B

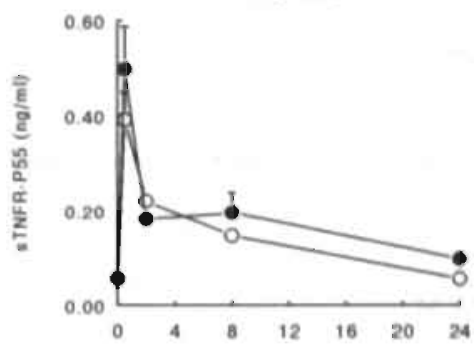

C

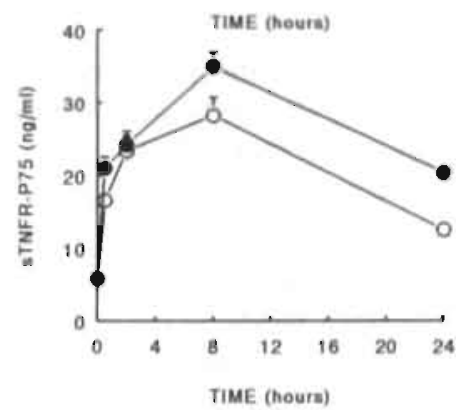

Figure 2: TNF and sTNFR levels after $10 \mu \mathrm{g}$ ( $n=14$; open circles) or $100 \mu \mathrm{g}$ LPS ( $n=12$; closed circels).
(A) TNF levels
(B) sTNFR-P55 levels
(C) sTNFR-P75 levels.

Data are expressed as means \pm SEM

In order to investigate whether triggering of TNFR-P55 was instrumental in this process, we administered human TNF, which can only trigger TNFR-P55. Injection of human TNF resulted in a rapid appearance of human TNF in the circulation with a peak of $1.6 \mathrm{ng} / \mathrm{ml}$ after 30 minutes (data not shown). Human TNF was no longer detectable after 2 hours. Moreover, this amount of hTNF did not result in significant amounts of circulating murine TNF. Also, human TNF appeared to induce an increase of both sTNFR in similar fashion as murine TNF, indicating that triggering of TNFRP55 is sufficient to cause an increase of both sTNFR-P55 and sTNFR-P75 levels (Fig $3 \mathrm{~A} / \mathrm{B})$. 

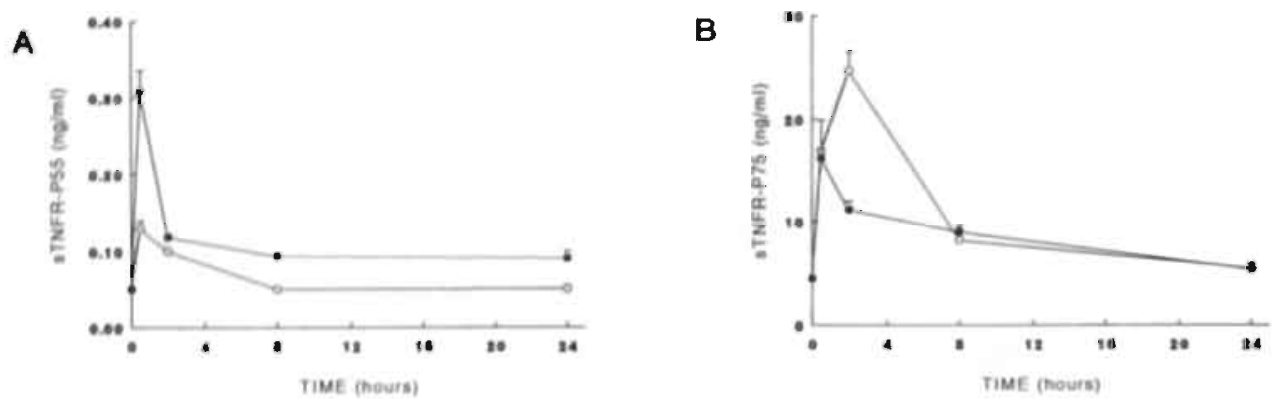

Figure 3 ; sTNFR levels after murine ( $n=12$; open circels) or human TNF injection $(n=12$; closed circels).

(A) sTNFR-P5s levels

(B) sTNFR-P75 levels.

Data are expressed as means \pm SEM

In order to further investigate whether the presence of TNF was necessary for the induction of increased sTNFR levels after LPS administration, we studied the influence of administration of the following anti-TNF agents: 1. a monoclonal anti-TNF antibody TN3; 2. sTNFR55-Fc; 3. sTNFR75-Fc. Administration of these agents without LPS injection did not result in the presence of circulating TNF, nor did they affect TNFR levels (data not shown). All 3 anti-TNF treatments significantly reduced TNF levels after LPS injection to non detectable levels as measured by the WEHI assay (data not shown). However, STNFR-P55 peak levels were significantly increased after 30 minutes in all 3 groups compared to control LPS data, although STNFR-P55 kinetics were unaffected by the three anti-TNF agents (TN3 vs LPS: $<<0.001$; sTNFR55-Fc vs LPS: $p=0.002$; sTNFR75-Fc vs LPS $p=0.032$; Fig 4A/B/C). Administration of TN3 did not significantly affect sTNFR-P75 levels after LPS Fig 4A). This was in sharp contrast to the enhanced increase of STNFR-P75 levels observed in the mice which received the sTNFR55-Fc or sTNFR75-Fc ( $<<0.001$ and $p=0.017$, resp.; Fig 4B/C).

IFN- $\gamma$ is known to play a role in LPS induced TNF release and LPS induced pathophysiology. Therefore we investigated whether IFN- $\gamma$ is involved in LPS induced TNFR kinetics. To this end, mice were treated with a monoclonal anti-muIFN- $\gamma$ antibody before LPS injection. The amount of antibody used was capable of depleting the mouse of all detectable circulating IFN- $\gamma$ and protects mice from a lethal endotoxin injection (22). The results obtained show that anti-IFN- $\gamma$ significantly reduced circulating TNF after LPS administration ( $\mathrm{P}<0.001$; Fig $5 \mathrm{~A})$. Paradoxically, while administration of anti-IFN- $\gamma$ reduced the increase of sTNFR.P55 levels $(p=0.044)$, it significantly enhanced the increase of sTNFR-P75 levels, without affecting the kinetics of both TNFR $(\mathrm{p}<0.001$; Fig $6 \mathrm{~A}$ ). 

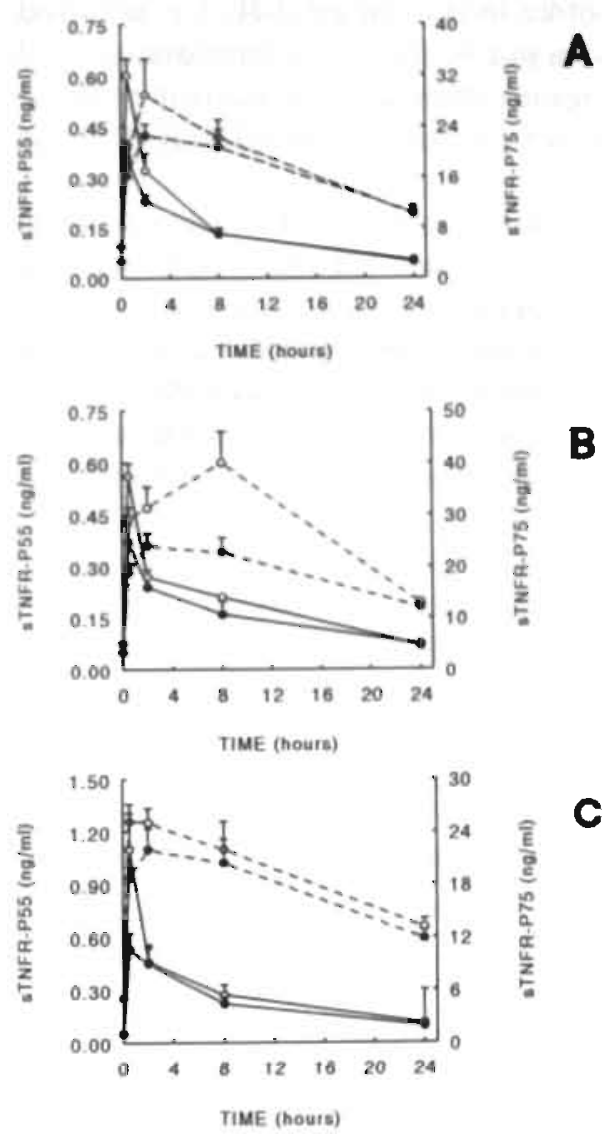

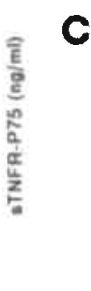

Figure 4: sTNFR levels after pretreatment with momoclonal anti-TNF antibody (TN3), $(n=16)$. sTNFR5S-Fc $(n=17)$ and sTNFR75. Fc $(n=25)$ before an injection of $10 \mu \mathrm{g}$ LPS ip (all $3 \mathrm{re-}$ presented by open circles) with the accompanying LPS control mice (represented by closed circels). Solid line represents STNFR-P55 levels, dashed line represents sTNFR-P75 levels.
(A) TN3 and control
(B) sTNFR55-Fc and control
(C) sTINFR75-Fc and control.

B
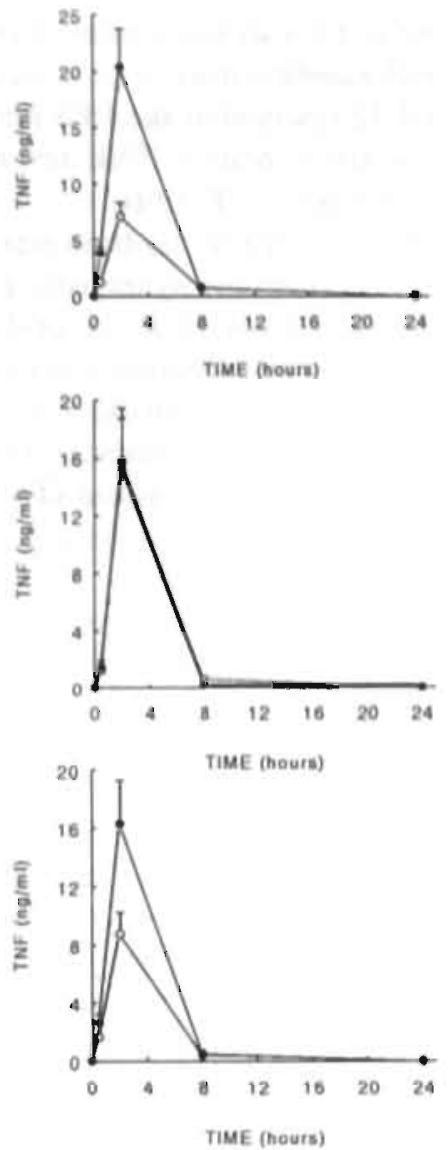

B

C

Figure 5: TNF levels after pretreatment with anti-IFN-Y $(n=10)$, IL-Ira $(n=16)$ or $L I F$ $(n=26)$ before $10 \mu \mathrm{g}$ LPS injection (all 3 rep. resented by open circles) and the accompany. ing control LPS levels (closed circles).
(A) anti-IFN- $\gamma$ and control
(B) IL-Ira and control
(C) LIF and control.

Data are expressed as means \pm SEM

Data are expressed as means \pm SEM 
Previous reports have shown that blocking IL-1 by pretreatment with an IL-1ra protects mice from a lethal endotoxin shock, which strongly suggest that $\mathrm{L}-1$ plays an important role in LPS induced pathophysiology. In order to investigate if $\mathrm{IL}-1$ is involved in TNF-R kinetics, mice were injected with IL-1ra just before LPS administration, and 4,8 , and 12 hours after the LPS injection. The results show that pretreatment with IL1ra does affect neither TNF levels (Fig 5B), nor the kinetics of sTNFR-P55 and sTNFR-P75 levels (Fig 6B).

Administration of LIF has been reported to protect mice from a lethal endotoxin shock. Moreover, a dramatic synergistic protection was seen when LIF was combined with sub-protective doses of IL-1B or TNF- $\alpha$. These data provide evidence that LIF may have an important physiological role in the host defense against endotoxin shock. LIF administration appeared to have no effect on circulating TNF levels after LPS injection $(p=0.076$; Fig 5C). Nevertheless, sTNFR-P55 increase was significantly enhanced after LIF treatment $(p=0.04)$, while sTNFR-P75 levels remained similar to the control LPS group (Fig 6C).

A
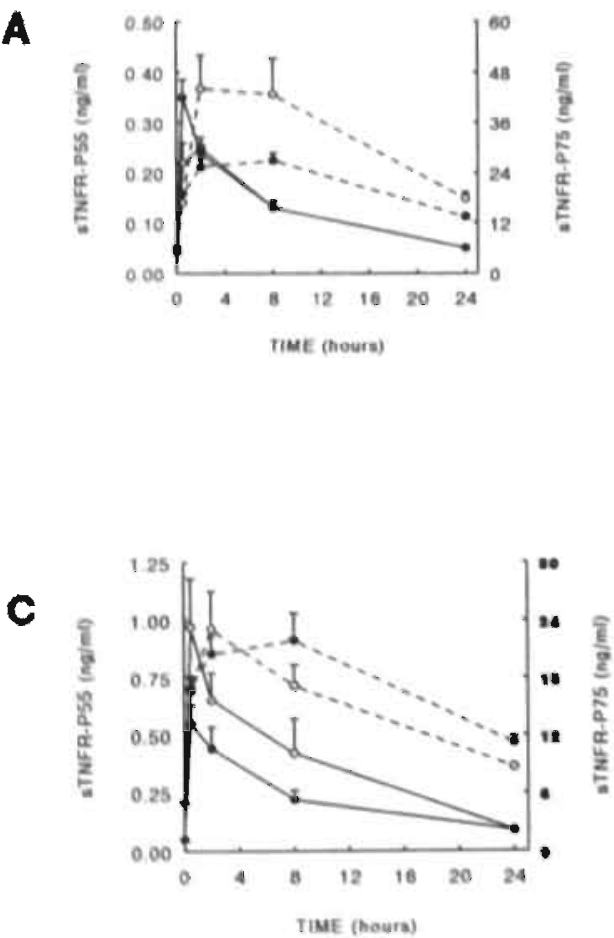

B

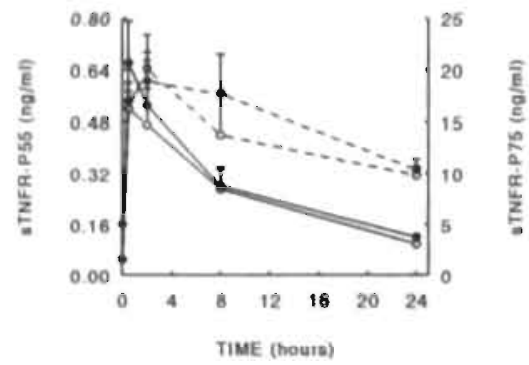

Figure 6: sTNFR levels after tretreatment with anti-IFN- $\gamma(n=19)$, IL-Ira $(n=16)$ or LIF $(n=$. 26) before LPS $(10 \mu \mathrm{g}$ ) injection (all 3 represented by open circels) with their accompanying LPS control levels (closed circels). Solid line represents sTNFR-P55 levels, the dashed line represents, sTNFR-P75 leveis.

(A) anti-IFN- $\gamma$ and control

(B) IL-1ra and control

(C) LIF and control.

Data are expressed as means $\pm \mathrm{SEM}$. 


\section{Discussion}

Although sTNFR-P55 and sTNFR-P75, the liberated extracellular domains of the two TNF receptors, share a high sequence homology, they are biochemically and immunologically distinct proteins $(3,31)$. Since also the predicted amino acid sequences of the intracellular regions of the two TNF receptors are distinct, it was concluded that the different intracellular domains transmit distinct signals upon TNF binding (32). In agreement with these data, Tartaglia et al. have shown that the two TNF receptors mediate distinct cellular responses, TNFR-P55 initiating signals for cytotoxicity, while TNFR-P75 generates signals for proliferation of thymocytes and cytotoxic T-cells (33). In some situations however, the receptors mediate the same effects, like the signals required for proliferative responses of peripheral blood mononuclear cells to PHA (34). The specific role of both TNFR is more easily investigated now TNF mutants reactive with a single TNFR type become available (35). The first results show that hTNF-R55specific TNF mutants reduce systemic toxicity in murine systems. Recently we reported substantial evidence showing that in mice STNFR-P75 in contrast to sTNFR-P55 is responsible for the inactivation of TNF and clearance from the circulation (9). Since our data show that STNFR-P75 is predominantly present in the circulation (in normal mice sTNFR-P55 levels range approximately from $60-100 \mathrm{pg} / \mathrm{ml}$ while there is $50-70$ times more sTNFR-P75 present, $\pm 5 \mathrm{ng} / \mathrm{ml}$ ) and since previous reports have shown that the Kd of mTNFR-P75 is approximately equal to the Kd of mTNFR-P55 (36), these observations support the fact that sTNFR-P75 is potentially a very potent inactivator of circulating TNF in mice. Besides circulating TNF, also a membrane associated form of $26 \mathrm{kD}$ can mediate biological effects such as cell killing by cell to cell contact and subsequent binding to the TNF receptor (37). Future experiments are necessary to unravel the influence of sTNFR and the biological activity of membrane bound TNF. We demonstrate that injection of endotoxin in mice results in a rapid increase in both STNFR-P55 and sTNFR-P75 levels observed as soon as 30 minutes after LPS injection. Nevertheless, the difference in basal sTNFR levels is maintained after LPS administration resulting in much higher sTNFR-P75 levels compared to sTNFR-P55 levels. sTNFR-P55 diminished after a peak at 30 minutes after LPS administration, sTNFRP75 levels increased to a maximum plateau level 4-8 hours after LPS injection and showed only a slow decrease afterwards. After 24 hours there are still significantly higher levels of sTNFR-P75 present in the circulation compared to levels in control levels, whereas sTNFR-P55 levels were back to control levels. Administration of higher amounts of LPS had no influence on kinetics of the two TNF receptors. However, while sTNFR-P55 peak level were not increased after higher amounts of LPS are given, the data revealed a small increase in STNFR-P75 levels after injection of higher amounts of LPS. After LPS stimulation peak values of $350 \mathrm{pg} / \mathrm{ml}$ of sTNFR-P55 and $50 \mathrm{ng} / \mathrm{ml}$ of sTNFR-P75 were found. These data seem to be in line with the theory that TNFR-P75 is responsible for the inactivation and clearance of TNF (9). 
The experiments show that murine and human TNF induce an increase in sTNFR levels, although the effect of murine TNF on sTNFR-P55 release is small. The human TNF data show that triggering of TNFR-P55 is sufficient to cause shedding of both sTNFR. However, since both sTNFR increase after LPS injection even before the detection of circulating TNF, it appears that other mechanisms besides TNF cause sTNFR shedding. Moreover, the experiments with anti-TNF reagents did not significantly reduce the increase of circulating sTNFR levels, while biologically active TNF in these animals was not detectable.

In contrast, the sTNF55-Fc and sTNF75-Fc, both strong inactivators of TNF, even caused a significant increase of both sTNFR-P55 and sTNFR-P75 levels. Possibly the absence of TNF as a ligand for the STNFR in these experiments resulted in an increased and prolonged presence of the sTNFR in the circulation. We have no explanation for the difference of effects on sTNFR levels between TN3 and the two sTNFRFc. An explanation could be that sTNFR-Fc constructs have a stronger inhibitory effect than the monoclonal antibody TN3. In conclusion our data indicate that LPS regulates sTNFR release directly or via other intermediate messengers than TNF.

Anti-IFN- $\gamma$ substantially and significantly decreased circulating TNF levels, which is in contrast with previous published data which showed that anti-IFN- $\gamma$ caused an increase of TNF leveis after LPS injection (22). The dosage and type of LPS used in this study may be responsible for the observed differences. Concerning the sTNFR levels, the data show that the anti-IFN- $\gamma$ antibody reduced sTNFR-P55 levels while increasing sTNFR.P75 levels. Whether this increase in sTNFR-P75 levels is responsible for the observed reduced circulating TNF levels remains to be investigated. However, the strongly reduced TNF levels in combination with enhanced sTNFR-P75 levels could play an important role in the protective effect of anti-IFN- $\gamma$ in case of a lethal endotoxemia.

Investigation on the effect of blocking the receptor for IL-1 by administration of IL-1 ra before a LPS injection, revealed that this treatment had no effect whatsoever on TNF and sTNFR levels. These data strongly suggest that IL-1 has no substantial role in the LPS induced TNF release, nor is it a mediator in the LPS induced sTNFR release in vivo. However, the mechanism by which IL-Ira protects an animal for lethal effects of LPS could be the fact that IL-1ra blocks the binding of IL-1 to its receptor, thereby negating the synergistic lethality of TNF and IL-1 both of which are induced by LPS.

The influence of Leukemia Inhibiting Factor (LIF), also called D-factor which is strongly protective in lethal endotoxemia, on LPS induced circulating TNF seemed of minor importance, resulting in a not significant reduction of circulating TNF levels. sTNFR-P55 levels were significantly increased, while sTNFR-P75 levels seemed similar to the levels after LPS alone. Due to its low levels, the observed increase in sTNFR-P55 levels seem of minor importance in relation to TNF inactivation in the circulation. Furthermore, the protective effect of LIF in lethal endotoxemia is not likely to be caused by a reduction in TNF and/or enhanced sTNFR-P55 levels, but may be 
based on other suggested mechanisms as the modulation of acute phase protein synthesis or the modulation of the hematopoietic cell populations $(21,38)$.

The data presented here provide evidence that sTNFR-P55 and sTNFR-P75 are regulated distinct from each other, since the observed increase or decrease of sTNFRP55 levels is not correlated with changes in STNFR-P75 levels. A distinct induction mechanism for release of the TNFR-P55 and the TNFR-P75 is not surprising, since differential TNF receptor expression patterns were found by immunochemistry; TNFRP75 is mainly found in the T-cell area whereas TNFR-P55 is being found in the germinal center of lymphoid tissue (39). The difference in regulation between both sTNFR was also reported after treatment of healthy volunteers with endotoxin with or without Ibuprofen: although STNFR-P75 in this experiment increased with increasing TNF concentrations, sTNFR-P55 remained unchanged, irrespective of the increases in TNF production (8). Nevertheless, sTNF-R regulation and function do not have to be identical in man and mouse. In man basal sTNFR-P55 and sTNFR-P75 levels are not substantially different, and in some diseases an increase in STNFR-P55 rather than in sTNFR-P75 has been reported (14).

Our results on the kinetics of sTNFR increase differ from previous reports, where sTNFR levels, established in human volunteers after LPS administration followed TNF release with a delay of 90 minutes (8). Whether this difference depends on differences in species or on other aspects remains to be investigated.

The physiological meaning of enhanced sTNFR levels is considered to be a protective mechanism against circulating TNF. Since sTNFR-P55 levels never exceed I ng/ml, sTNFR-P55 will not be instrumental in substantially reducing the cytotoxicity of circulating TNF, present in levels up to $20 \mathrm{ng} / \mathrm{ml}$ during endotoxemia. However, peak. levels of sTNFR-P75 up to $50 \mathrm{ng} / \mathrm{ml}$ would lead to a very substantial reduction of free bioactive circulating TNF, and facilitate by complex formation the clearing of TNF by the kidneys. On the other hand, the increase of both STNFR results in a decreased amount of receptors on the cell membrane which could reduce the sensitivity of cells to TNF.

In conclusion, our data show that not only LPS, but also murine TNF and human TNF can induce the release of STNFR. The data reveal that TNF itself is most likely only minimally involved in LPS enhancement of sTNFR levels. Considering the effects of the cytokines which were shown to play a role in the LPS induced pathophysiology (LIF, IFN- $\gamma$, IL-1), we observed that although IFN- $\gamma$ and LIF are involved in the sTNFR release and affect STNFR release, other factors are probably more crucial in this process. Future experiments are essential to further unravel the processes which lead to sTNFR release and the exact physiological role of enhanced sTNFR levels. 


\section{References}

1. Engelmann, H., H. Holtmann, C. Brakebush, Y.S. Avni, I. Sarov, Y. Nophar, E. Hadas, O. Leitner, and D. Wallach. Antibodies to a soluble form of a tumor necrosis factor (TNF) receptor have TNF-like activity. J. Biol. Chem. 1990;265:14497-14504.

2. Engelmann, H., D. Novick, and. D. Wallach. Two tumor necrosis factor-binding proteins purified from human urine. Evidence for immunological cross-reactivity with cell surface tumor necrosis factor receptors. J. Biol. Chem. 1990;265:1531-1536.

3. Brockhaus, M., H.J. Schoenfeld, E.J. Schlaeger, W. Hunziker, W. Lesslauer, and H. Loetscher. Identification of two types of tumor necrosis factor receptors on human cell lines by monoclonal antibodies. Proc. Natl. Acad. Sci. USA. 1990;87:3127-3131.

4. Vandenabeele, P., W. Declercq, D. Vercammen, M. Van de Craen, J. Grooten, H. Loetscher, M. Brockhaus, W. Lesslauer, and W. Fiers. Functional characterization of the human Tumor Necrosis Factor Receptor p75 in a transfected rat/mouse T cell hybridoma. J. Exp. Med. 1992:176:1015-1024.

5. Engelmann, H., D. Aderka, M. Rubinstein, D. Rotman, and D. Wallach. A tumor necrosis factor-binding protein purified to homogeneity from human urine protects cells from tumor necrosis factor toxicity. J. Biol'. Chem. 1989;264:11974-11980.

6. Seckinger, P., S. Isaaz, and J.M. Dayer. Purification and biologic characterization of a specific tumor necrosis factor $\alpha$ inhibitor. J. Biol. Chem. 1989;264:1/966-1/973.

7. Peetre, C., H. Thysell, A. Grubb, and I. Olsson. A tumor necrosis factor binding protein is present in human biological fluids. Eur. J. Haematol. 1988:41:414-419.

8. Spinas, G.A., U. Keller, M. Brockhaus. Release of soluble receptors for Tumor Necrosis Factor (TNF) in relation to circulating TNF during experimental endotoxemia. J. Clin. Invest. 1992;90:533-536.

9. Bemelmans, M.H.A., D.J. Gouma, and W.A. Buurman. Influence of nephrectomy on Tumor Necrosis Factor (TNF) clearance in a murine model. J. Immunol.' 1993;150:2007-2017.

10. Porteu, F., and C. Natan. Shedding of Tumor Necrosis Factor by activated human neutrophils. J. Exp. Med. 1990;172: 599-607.

11. Porteu, F., M. Brockhaus, D. Wallach, H. Engelmann, and C. Natan. Human neutrophil elastase releases a ligand-binding fragment from the 75-kDa Tumor Necrosis Factor (TNF) receptor. J. Biol. Chem. 1991;266:18846-18853.

12. Ding, A.H., F. Porteu. Regulation of Tumor Necrosis Factor Receptor on phagocytes. P. Soc. Exp. Biol. Med. 1992;200:458-465.

13. Brockhaus, M., Y. Bar-Khayim, S. Gurwicz, A. Frensdorff, and N. Haran. Plasma Tumor Necrosis. Factor soluble receptors in chronic renal failure. Kidney Int. 1992;42:663-667.

14. Andus, T., V. Gross, A. Holstege, M. Ott, M. Weber, M. David, H. Gallati, W. Gerok, and J. Scholmerich. High concentrations of soluble Tumor Necrosis Factor receptors in ascites. Hepatolgy 1992;16:749-755.

15. Aderka, D., H. Engelmann, V. Homik, Y. Skomick, Y. Levo, D. Wallach, and G. Kushtai. Increased serum levels of soluble receptors for Tumor Necrosis Factor in cancer patients. Cancer Res. 1991:51:56025607.

16. Cope, A.P., D. Aderka, M. Doherty, H. Engelmann, D. Gibbons, A.C. Jones, F.M. Brennan, R.N. Maini, D. Wallach, and M. Feldmann. Increased levels of soluble Tumor Necrosis Factor receptors in the sera and synovial fluid of patients with rheumatic diseases. Arthritis Rheum. 1992;35:1160-1169.

17. Van Zee, K.J., T. Kohno, E. Fischer, C.S. Rock, L.L. Moldawer, and S.F. Lowry. Tumor Necrosis Factor soluble receptors circulate during experimental and clinical inflammation and 
can protect against excessive Tumor Necrosis Factor $\alpha$ in vitro and in vivo. Proc. Natl. Acad. Sci. $1992 ; 89: 4845-4849$.

18. Engelberts, I., A. Moller, G.J.M. Schoen, C.J. van der Linden, and W.A. Buuman. Evaluation of measurement of human TNF in plasma by elisa. Lymphokine Res. 1991;10:69-76.

19. Sheehan K.C.F., N.H. Ruddle, and R.D. Schreiber. Generation and characterisation of hamster monoclonal antibodies that neutralizes Murine Tumor Necrosis Factors. J Immunol. 1989;142: 3884-3893.

20. Lesslauer. W., H. Tabuchi, R. Gentz, M. Brockhaus, E.J. Schlaeger, G. Grau, P.F. Piguet, P. Pointaire, P. Vassali, and H.R. Loetscher. Recombinant soluble tumor necrosis factor receptor proteins protect mice from lipopolysaccharide-induced lethality. Eur. J. Immunol. 1991;21: 2883-2886.

21. Alexander, H.R., G.G.H. Wong, G.M. Doherty, D.J. Venzon, D.L. Fraker, and J.A. Nonton. Differentiation Factor/Leukemia Inhibitory Factor protection against lethal endotoxemia in mice: Synergistic effect with Interleukin-1 and Tumor Necrosis Factor. J. Exp. Med. 1992; 175:1139-1142.

22. Doherty, G.M., J.R. Lange, H.N. Langstein, H.R. Alexander, C.M. Buresh, and J.A. Nonton. Evidence for IFN- $\gamma$ as a mediator of the lethality of endotoxin and Tumor Necrosis Factor- $\alpha$. J. Immunol. 1992;149:1666-1670.

23. Alexander, H.R., G.M. Doherty, D.J. Venzon, M.J. Merino, D.L. Fraker, and J.A. Nonton. Recombinant interleukin-1 receptor antagonist (IL-1ra): Effective therapy against gramnegative sepsis in rats. Surgery 1992;112:188-193.

24. Alexander, H.R., G.M. Doherty, C.M. Buresh, D.J. Venzon, and J.A. Norton. A recombinant human receptor antagonist to interleukin 1 improves survival after lethal endotoxemia in mice. J. Exp. Med. 1991;173:1029-1032.

25. Dentener, M.A., J.W. Greve, J.G. Maessen, and W.A. Buurman. Role of tumor necrosis factor in the phenomenon of the enhanced sensitivity of animals to endotoxin after exposure to lead. Immunopharmacol and Immunotoxicol. 1989;11:321-324.

26. Ashkenazi, A., S.A. Marsters, D.J. Capon, S.M. Chamov, I.S. Figari, D. Pennica, D.V. Goeddel, M.A. Palladino, and D.H. Smith. Protection against endotoxic shock by a Tumor Necrosis Factor receptor immunoadhesin. Proc. Natl. Acad. Sci. 1991;88:10535-10539.

27. Rollinghoff, M., and N.L. Wamer. Specificity of in vivo tumor rejection assessed by mixing immune spleen cells with target and unrelated tumor cells. Proc. Soc. Exp. Med. 1973;144: 813-818.

28. Espevik, T., and J. Nissen-Meyer. A highly sensitive cell line, WEHI 164 clone 13, for measuring cytotoxic factor /tumor necrosis factor from human monocytes. J. Immunol. Methods. 1986;95:99-105.

29. Hanssen, M.B., S.E. Nielsen, and K. Berg. Re-examination and further development of a precise and rapid dye method for measuring cell growth/cell kill. J. Immunol. Methods. $1989 ; 119: 203-210$.

30. Norusis, M.J. ed. SPSS/PC+ V3.1 BASE MANUAL for the IBM PC/XT/AT and PS/2. SPSS Inc., Chicago, USA.

31. Hohmann, H.P., R. Remy, M. Brockhaus, and A.P.G.M. van Loon. Two different cell types have different major receptors for human tumor necrosis factor (TNFoi). J. Biol. Chem. 1989:264:14927-14934.

32. Dembic, Z., H. Loetscher, U. Gubler, Y.E. Pan, H. Lahm, R. Gentz, M. Brockhaus, and W. Lesslauer. Two human TNF receptors have similar extracellular, but distinct intracellular, domain sequences. Cytokine 1990;4:231-237.

33. Tartaglia, L.A., R.F. Weber, I.S. Figari, C. Reynolds, M.A. Palladino, Jr., and D.V. Goeddel. The two receptors for tumor necrosis factor mediate distinct cellular responses. Proc. Natl. Acad. Sci, 1991;88:9292-9296. 
34. Gehr, G., R. Gentz, M. Brockhaus, H. Loetscher, and W. Lesslauer. Both Tumor Necrosis. Factor Receptor types mediate proliferative signals in human mononuclear cell activation. $J$. Immunol. 1992;149:911-917.

35. Van Ostade, X., P. Vandenabeele, B. Everaerdt, H. Loetscher, R. Gentz, M. Brockhaus, W. Lesslauer, J. Tavernier, P. Brouckaert, and W. Fiers. Human TNF mutants with selective activity on the P55 receptor. Nature 1993:361:266-269.

36. Goodwin, R.G, D. Anderson, R. Jerzy, T. Davis, C.I. Brannan, N.G. Copeland, N.A. Jenkins, and C.A. Smith. Molecular cloning and expression of the type 1 and 2 murine receptors for tumor necrosis factor. Mol. Cell. Biol. 1991;11:3020-3026.

37. Kriegler, M., C. Perez, K. DeFay, L. Albert, and S.D. Lu. A novel form of TNF/Cachectin is a cell surface cytotoxic transmembrane protein: ramifications for the complex physiology of TNF. Cell 1988;53:45-53.

38. Metcalf, D., N.A. Nicola, D.P. Gearing. Effects of injected leukemia inhibitory factor on hematopoietic and other tissues in mice. Blood 1990;76:50-56.

39. Ryffel, B., M. Brockhaus, U. Durmuller, and F. Gudat. TNF receptors in lymphoid tissues and lymphomas: source and site of action of tumor necrosis factor $\alpha$ (TNF $\alpha$ ). Am. J. Pathol. 1991:139:7-15. 


\section{Chapter 9}

IN VIVO T-CELL ACTIVATION BY ANTI-CD3 MAB INDUCES SOLUBLE TNF RECEPTOR RELEASE IN MICE: EFFECTS OF PENTOXIFYLLINE, METHYLPREDNISOLONE, ANTI-TNF AND ANTI-IFN- $\gamma$ ANTIBODIES

M.H.A. Bemelmans, D. Abramowicz, D.J. Gouma, M. Goldman, W.A. Buurman.

J. Immunol., in press. 


\begin{abstract}
Injection of anti-CD3 is accompanied by an increase in systemic TNF, a mediator of the physiological changes induced by anti-CD3 injection. Various mechanism have been reported to be responsible for TNF inactivation and clearance. Recently it has become evident that circulating soluble TNF receptors (P55 and P75), which are known to increase in response to TNF inducers such as LPS, represent a natural protection mechanism against circulating TNF.

Here we show that triggering the $T$ cell receptor by anti-CD3 injection results in a strong induction of both systemic TNF and soluble TNF receptor release. Maximal levels of TNF were reached after 2 hours $(10 \mathrm{ng} / \mathrm{ml})$. Maximum levels of P55 (450 $\mathrm{pg} / \mathrm{mi}$ ) were reached between 0.5 and 8 hours, while highest levels of P75 were reached after 2 hours $(28 \mathrm{ng} / \mathrm{ml})$. Since TNF and IFN- $\gamma$ are supposed to be involved in the pathophysiology of the anti-CD3 response, we investigated the influence of in vivo neutralization of TNF and IFN- $\gamma$. Injection of mAb's to TNF and IFN- $\gamma$ significantly reduced systemic TNF levels as well as both soluble TNF receptor levels. Two inhibitors of anti-CD3 induced TNF release, steroids and pentoxifylline both reduced TNF levels and P75 levels without affecting P55 levels.

The results show that T-cell activation induces both systemic TNF release and release of both soluble TNF receptors. Although TNF and IFN- $\gamma$ are involved in this mechanism, their role does not seem to be crucial.
\end{abstract}

\title{
Introduction
}

Increased levels of sTNFR are considered to be protective by both inactivating systemic TNF and enhancing the renal clearance of TNF (1). Moreover, since sTNFR are liberated by proteolytic cleavage from the cell membrane (2-4), the loss of cell surface TNF receptors can lead to a transiently decreased responsiveness to TNF (4).

Soluble TNF-Receptors (sTNFR) are released in vivo in situations in which systemic TNF is present (5-9). Two soluble TNF Receptors (sTNFR-P55 and sTNFR-P75) circulate in vivo and are upregulated in response to endotoxin. LPS was reported to cause an increase in STNFR in man, baboon and mice $(1,6,7)$. In a previous study we showed that TNF itself is not playing a crucial role in LPS-induced sTNFR release in mice (10), although circulating TNF does induce an increase in sTNFR levels in mice.

T-cell mediated immune processes also lead to TNF release both in vivo (11-13) and in vitro (14). In agreement with these data, enhanced STNFR levels have been observed in rheumatoid arthritis and systemic lupus erythematosus, diseases in which T-cell mediated immunity is thought to be involved (5).

In this study, we analyzed the evolution of sTNFR serum levels in mice injected with the $145-2 \mathrm{C} 11 \mathrm{mAb}$, an anti-mouse $\mathrm{CD} 3 \mathrm{mAb}$ which induces polyclonal $\mathrm{T}$ cell activation and TNF release. We took advantage of this model to investigate the effects of 
corticosteroids, pentoxifylline, anti-TNF and anti-IFN- $\gamma$ antibodies on the release of sTNFR associated with $\mathrm{T}$ cell activation.

\section{Materials and methods}

Mice. Six to nine week old female DBA/2 and $n u / n u$ mice were purchased from Iffa Credo (L'Arbresle, France).

Reagents. Bovine Serum Albumin, 3-(4,5-dimethylthiazol-2-yl)-2,5 diphenyltetrazolium bromide (MTT), N,N-dimethyl formamide and para-aminohippuric acid (PAH) were obtained from Sigma (St. Louis, MO); 3, 3',5, 5'- tetramethylbenzidine (TMB) was obtained from Kirkegaard \& Perry Laboratories Inc. (Gaithersburg. Maryland). Culture medium consisted of RPMI 1640 (Gibco, Paisley, U.K.) supplemented with $10 \%$ bovine calf serum (Hyclone, Logan, UT), penicillin $100 \mathrm{U} / \mathrm{ml}$ and streptomycin $100 \mu \mathrm{g} / \mathrm{ml}$ (Flow, Irvine, U.K.). Sodium dodecyl sulfate was obtained from Bio-Rad (Richmond, CA). Peroxidase conjugated goat anti rabbit IgG was obtained from Jackson, Westgrove, PA. Polyclonal rabbit anti-murine TNF antibodies (RaMT) were produced by injecting rabbits with murine TNF. TN3 (15) is a hamster monoclonal antibody specific for murine TNF (kindly provided by Celltech Slough, UK). Pentoxifylline (PTX) was obtained from Torental (Hoechst Pharmaceuticals, Frankfurt, Germany), methylprednisolone (m-PDS) was obtained from Upjohn (Kalamazoo, MI). The following agents were obtained through the courtesy of the respective firms or persons: Recombinant murine TNF (kindly provided by BASF/Knoll, Ludwigshafen, FRG); recombinant murine TNFR-P55 and TNFR-P75, and rabbit anti murine sTNFRP55 and P75 (kindly provided by Dr. D.V. Goeddel, Genentech, San Francisco, CA); anti-MuIFN- $\gamma$ (F3) was kindly provided by Dr. H. Heremans (Leuven, Belgium).

Production of the anti-CD3 $m A b$. The hamster mAb 145-2C11 directed against the mouse CD3 complex was obtained in ascites form. The endotoxin content of this preparation was less than $100 \mathrm{pg} / \mathrm{ml}$. The antibody was dissolved in $200 \mu \mathrm{l}$ of PBS and injected ip.

Experimental protocol. (A) We first investigated the kinetics of TNF and sTNFR release in serum after injection of $0.4,2,10$, and $50 \mu \mathrm{g}$ of the anti-mouse CD3 145$2 \mathrm{C} 11 \mathrm{mAb}$. Blood samples $(\mathrm{n}=6)$ were obtained by orbital puncture under light ether anesthesia at $0.5,2,8,24,48$, and $72 \mathrm{~h}$ after $145-2 \mathrm{C} 11$ injection. For each anti-CD3 dose, one group of six mice were bled at $0.5,8$, and $48 \mathrm{~h}$, while another group was bled at 2, 24, and $72 \mathrm{~h}$. Pilot experiments showed that this schedule of blood sampling did not interfere with TNF or sTNFR levels. Zero timepoints were obtained from a separate group of mice $(n=8)$ belonging to the same batch.

(B) We next investigated the effects of pretreatment with anti-TNF (TN3), anti-IFN- $\gamma$ (F3), PTX, and m-PDS on TNF and sTNFR release induced by $50 \mu \mathrm{g}$ of 145-2C11. 
Each agent was dissolved in $200 \mu \mathrm{l}$ of PBS and injected ip. Group 1 received $750 \mu \mathrm{g}$ TN3 6 h before anti-CD3 injection, as described previously (16); group 2 received 100 $\mu \mathrm{g}$ of F3, a dose sufficient to neutralize IFN- $\gamma$ production in mice (17); group 3 received $2 \mathrm{mg}$ PTX $1 \mathrm{~h}$ before and group 4 received $1 \mathrm{mg} \mathrm{m}-\mathrm{PDS} 2 \mathrm{~h}$ before anti-CD3 challenge, as based on our previous observations $(18,19)$. The effect of injection of the $\mathrm{mAB}$ 's, PTX or m-PDS alone was investigated in control mice $(n=12)$ for each reagent. Blood was sampled $30 \mathrm{~min}(\mathrm{n}=4), 2 \mathrm{hr}(\mathrm{n}=4)$ and $6 \mathrm{hr}(\mathrm{n}=4)$ after injection. These treatments did not affect sTNFR-P55 levels, while a minimal increase in sTNFRP75 levels was observed (from 5 till $6.5 \mathrm{ng} / \mathrm{ml}$ ). Therefore, we consider the effect of injection of these agents on sTNFR levels negligible.

Renal blood flow (RBF) measurements. RBF was assessed by modification of the method of Selkurt et al (20). Instead of administration of PAH by catheters we administered PAH by means of an osmotic minipump implanted intraperitoneally. Osmotic Alzet minipumps (model 1003D, Alza corporation Palo Alto, CA) were filled with $100 \mu \mathrm{l}$ of $1.8 \mathrm{M} \mathrm{PAH}$, and incubated for 4 hours at $37 \mathrm{C}$ in sterile saline in order to obtain stable flow. Thereafter, the pumps were implanted ip in 6 mice. Eighteen hours after implantation (time point at which steady state was reached, data not shown) we injected 3 mice with $50 \mu \mathrm{g}$ of $145-2 \mathrm{Cl}$, while the other 3 mice received saline. Blood samples were taken after 8, 24, and 30 hours and collected on ice in heparinized cups (Microvette CB 1000, Sarstedt, Nümbrecht, FRG). For PAH determinations, 100 $\mu$ of whole blood was deproteinized with $100 \mu \mathrm{l}$ of $50 \%$ trichloracetic acid, thoroughly mixed, allowed to stand for deproteinization (4. C, 30 minutes) and centrifuged after which the supernatants were stored at $-70 \mathrm{C}$. PAH was determined by standard techniques as described previously (21). RBF was calculated as input divided by the serum concentration of $\mathrm{PAH}$ in $\mathrm{ml} / \mathrm{min}(22)$.

Enzyme linked immunosorbent assay (ELISA) for murine TNF. ELISA for murine TNF was performed as described earlier by Dentener (23). In short: A 96-well immuno maxisorp plate (Nunc, Roskilde, Denmark) was coated with TN3. Aspecific binding was blocked with BSA. After washings, $50 \mu$ diluted serum sample $(25 \mu \mathrm{l}$ serum/ 25 $\mu \mathrm{l}$ PBS) was added to each well. A standard titration curve was obtained by making a serial dilution of a known sample of murine recombinant TNF in normal murine serum. Subsequently, plates were washed and incubated with a polyclonal RaMT antiserum followed by a peroxidase conjugated goat anti rabbit IgG and substrate TMB, activated with $\mathrm{H}_{2} \mathrm{O}_{2}$. The reaction was stopped and optical density was read. The ELISA has a lower detection limit of $50 \mathrm{pg} / \mathrm{ml}$ TNF. This elisa detects both free TNF and TNF bound to TNF receptors.

WEHI 164 cytotoxicity bioassay. Biological TNF activity was measured using the murine fibrosarcoma WEHI 164 cell line (24). The MTT-method was used to assess cell killing as described previously (25). A standard titration curve was obtained by making a serial dilution of a known quantity of a murine rTNF sample. The dilution 
giving rise to $50 \%$ lysis was correlated to the $\mathrm{LD}_{50}$ of the standard curve. $\mathrm{LD}_{50}$ ranged between 10 and $40 \mathrm{pg} / \mathrm{ml}$.

Enzyme linked immunosorbent assay for soluble murine TNF-Receptors. ELISA for murine sTNFR was performed as described earlier (10). In short: a 96 well immunomaxisorp plate (Nunc, Roskilde, Dennnark) was coated with rabbit anti-soluble murine TNFR-P55 or rabbit anti-soluble murine TNFR-P75 $(50 \mu \mathrm{l})$. Aspecific binding was blocked with BSA. After washings, $50 \mu$ liluted serum sample (1:10) was added to each well. A standard titration curve was obtained by making a serial dilution of a known sample of recombinant murine TNFR-P55 or TNFR-P75, resp. Subsequently, plates were washed and incubated with biotinylated polyclonal rabbit anti-soluble mTNFR-P55 or rabbit anti soluble-mTNFR-P75. After washings, plates were incubated with streptavidin peroxidase followed by enzyme reaction. The detection limit for murine sTNFR-P55 is $5 \mathrm{pg} / \mathrm{ml}$ and for sTNFR-P75 $50 \mathrm{pg} / \mathrm{ml}$. Pilot experiments showed that sTNFR levels are constant between different batches of DBA/2 mice. The sTNFRP55 baseline levels of these mice were ranging from $55-80 \mathrm{pg} / \mathrm{ml}$ and sTNFR-P75 baseline levels from from $4.6-5.4 \mathrm{ng} / \mathrm{ml}$.

Statistical analysis. Analysis of variance (ANOVA) was used for comparison of differences in serum TNF and TNFR levels (26). Data are expressed as means \pm SEM unless stated otherwise. Probability values below 0.05 were considered to be statistically significant.

\section{Results}

Kinetics and dose response of anti-CD3 induced TNF production. As previously reported (27), serum TNF levels increased as a result of 145-2C11 injection. While TNF peaked at $2 \mathrm{~h}$ with all doses of anti-CD3, it increased from $4,9 \mathrm{ng} / \mathrm{ml}$ with $0.4 \mu \mathrm{g}$ $145-2 \mathrm{C} 11$ to up to $10 \mathrm{ng} / \mathrm{ml}$ with higher doses (Fig.1). The highest anti-CD3 dose (50 $\mu \mathrm{g}$ resulted in a second TNF peak in the circulation after $48-72 \mathrm{~h}(\mathrm{p}<0.01)$ Lack of serum TNF release in nude mice injected with $50 \mu \mathrm{g}$ of $145-2 \mathrm{C} 11$ ascertained that TNF release in DBA/2 animals was related to the anti-T-cell properties of the 1452Cll preparation (data not shown).

Kinetics and dose response of anti-CD3 induced STNFR release. Fig 2 shows that $T$ cell activation by anti-CD3 $\mathrm{mAb}$ induced sTNFR release into the circulation. sTNFRP55 release was dose dependent (Fig 2A). As soon as 30 min. after injection sTNFRP55 levels increased in the $0.4 \mu \mathrm{g}$ and $2 \mu \mathrm{g}$ group from baseline $(75 \mathrm{pg} / \mathrm{ml})$ to 200 $\mathrm{pg} / \mathrm{ml}$, while in the 10 and $50 \mu \mathrm{g}$ groups levels were increased to $375-450 \mathrm{pg} / \mathrm{ml}$. Maximum sTNFR-P55 levels reached a plateau between 0.5 and $8 \mathrm{hr}$ after mAb administration. Whereas the STNFR-P55 levels of the 3 lower doses of anti-CD3 returned to normal within $72 \mathrm{hr}$, the levels in the $50 \mu \mathrm{g}$ group remained elevated. 
The base line of sTNFR-P75 levels of approximately $4.5 \mathrm{ng} / \mathrm{ml}$ is almost 60 times higher than that of sTNFR-P55 levels (as we reported earlier for other mice strains). In response to mAb 145-2C11 sTNFR-P75 levels showed slightly different kinetics (Fig 2B). The two lower doses $(0.4$ and $2 \mu \mathrm{g})$ caused only a minor increase after 30 min (from 5 to $7 \mathrm{ng} / \mathrm{ml}$ ), the levels peaked after 2 hours at 22 and $28 \mathrm{ng} / \mathrm{ml} \mathrm{resp.,} \mathrm{and}$ decreased thereafter reaching near normal levels after $24 \mathrm{hr}$. The two higher doses (10 and $50 \mu \mathrm{g}$ ) resulted in a massive increase as soon as $30 \mathrm{~min}$ after injection till 20 $\mathrm{ng} / \mathrm{ml}$. While the peak levels after 2 hours were almost identical to the $2 \mu \mathrm{g}$ group, they remained elevated up to 8 hours, whereafter the levels decreased. While the sTNFR-P75 levels in the $10 \mu \mathrm{g}$ group decreased to normal levels after $72 \mathrm{hr}$, they were still elevated in the $50 \mu \mathrm{g}$ group.

Eisure 1. TNF levels after anti-CD3 injection, $\stackrel{\mu}{z}$ measured by Elisa. Open circles represent TNF levels after $0.4 \mu \mathrm{g}$, closed circles after $2 \mu \mathrm{g}$. open triangles after $10 \mu \mathrm{g}$ and closed triangles after $50 \mu \mathrm{g}$ of anti-CD3 mAb. The mAb was injected ip dissolved in $200 \mu$ PBS. Data are expressed as means \pm SEM. Every time point represents 6 mice per group.

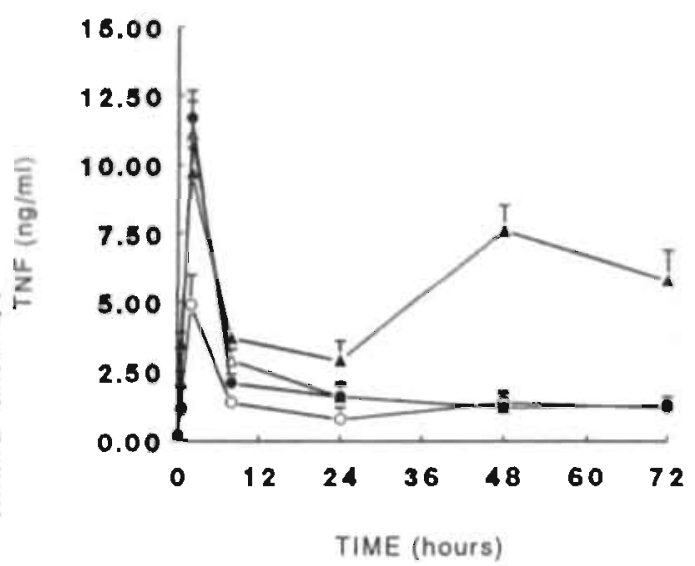

Effects of anti-TNF, anti-IFN- $\gamma$, PTX and m-PDS on TNF and sTNFR levels in anti$C D 3$ injected mice. As previously described, pretreatment with the anti-TNF mAb TN3 $(750 \mu \mathrm{g})$ completely blocked the release of TNF after 145-2C11 injection as assessed by the WEHI bioassay ( $p<0.001$; data not shown). We used the bioassay in this setting since the TN $3 \mathrm{mAb}$ injected to neutralize TNF is also used in the TNF elisa, which prevents its use. Both sTNFR-P55 levels and sTNFR-P75 levels were significantly reduced compared to the control anti-CD3 group $(p=0.003$ and $p<0.001$ resp; Fig 4A/Fig 5A), although they were still elevated compared to baseline levels.

Anti-IFN- $\gamma$ treatment resulted in a significant reduction of circulating TNF $(p<0.001$; Fig 3), with a $30 \%$ reduction in peak value. Although sTNFR-P55 levels and sTNFRP75 levels were significantly decreased compared to the anti-CD3 control group $(p=0.006$, $p<0.001$ resp.; Fig 4B/Fig 5B), they were significantly above baseline levels. 


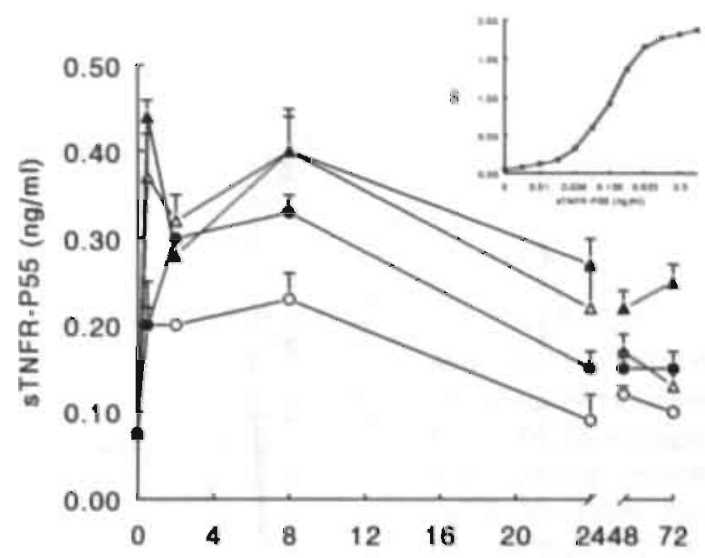

A

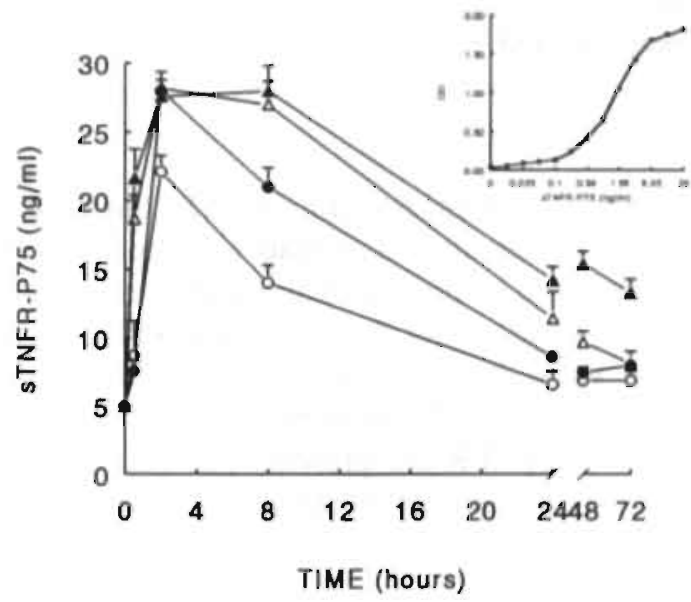

B

Figure 2: sTNFR levels after anti-CD3 injection. Upper graph A represents sTNFR-P55 levels. The inset shows the standard curve for sTNFR-P55. Lower graph B represents sTNFR-P75 levels. The inset shows the standard curve for sTNFR-P75. Open circles represent sTNFR levels after $0.4 \mu \mathrm{g}$, closed circles after $2 \mu \mathrm{g}$, open triangles after $10 \mu \mathrm{g}$ and closed triangles after $50 \mu \mathrm{g}$ of anti-CD3 mAb. Data are expressed as means \pm SEM. Every time point represents 6 mice per group. Insert gives detailed view of the first 8 hours after anti-CD3 injection.

PTX pretreatment significantly reduced TNF levels ( $p<0.001$; Fig 3) with a $44 \%$ reduction in peak value. It did not have any effect on the increase in STNFR.P55 levels after anti-CD3 treatment while it significantly reduced sTNFR-P75 levels, which were however still clearly elevated above baseline levels ( $<<0.001$; Fig 4C/Fig 5C).

$\mathrm{m}$-PDS pretreatment resulted in reduction of TNF release with peak value $60 \%$ lower than without pretreatment ( $\mathrm{p}<0.001$; Fig 3 ). While sTNFR-P55 levels were similar to the anti-CD3 control group, sTNFR-P75 levels were significantly reduced $(p<0.001$; Fig 4D/Fig SD), but they were still statistically higher than baseline levels. 
Figure 3. TNF levels after anti-CD3 injection with or without pretreatment, as measured by Elisa. Mice were challenged with $50 \mu \mathrm{g}$ of 145-2C1I without pretreatment (open triangles) or after pretreatment with either anti-IFN- $\gamma$ $\mathrm{mAb}(100 \mu \mathrm{g})$ (open circles), PTX ( $2 \mathrm{mg})$ (closed triangles), or m-PDS (1mg)(closed circles). Data are expressed as means \pm SEM for 6 mice at each time point.

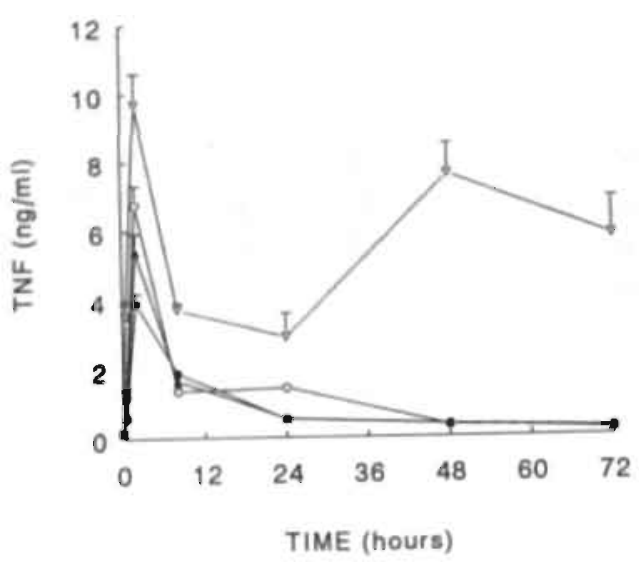

Effects of 145-2Cl1 injection on Renal Blood Flow (RBF) in mice. Increased levels of sTNFR have been observed in patients and animals with renal failure and signs of renal tubular necrosis were reported to be present in anti-CD3 treated animals $24-48 \mathrm{hr}$ after injection of the mAb (19). To ascertain that the observed increases in STNFR leveis after anti-CD3 treatment were due to T-cell activation and not to impaired renal function, we measured $\mathrm{RBF}$ up to 30 hours after $145-2 \mathrm{C} 11$ treatment, the time period in which increased levels of sTNFR are present. The data showed a slight but not significant decrease in RBF at 24 and $30 \mathrm{~h}$, which is unlikely to play any significant role in the early and massive increase in STNFR levels observed (Table 1).

Table 1. Renal blood flow (ml/min) after anti-CD3 injection *

$$
8 \mathrm{hr} \quad 24 \mathrm{hr} \quad 30 \mathrm{hr}
$$

\begin{tabular}{llll}
\hline Control $(n=3)^{4}$ & $2.55 \pm 0.74^{4}$ & $3.9 \pm 1.3$ & $3.1 \pm 1$ \\
Anti-CD3 $(n=3)$ & $2.40 \pm 0.16$ & $3.0 \pm 0.25$ & $2.6 \pm 0.2$
\end{tabular}

$50 \mu \mathrm{g}$ of 145-2C11 was administered ip in $200 \mu \mathrm{l}$ PBS.

' control animals received $200 \mu \mathrm{l}$ PBS ip.

' Data are expressed as means \pm SEM. 

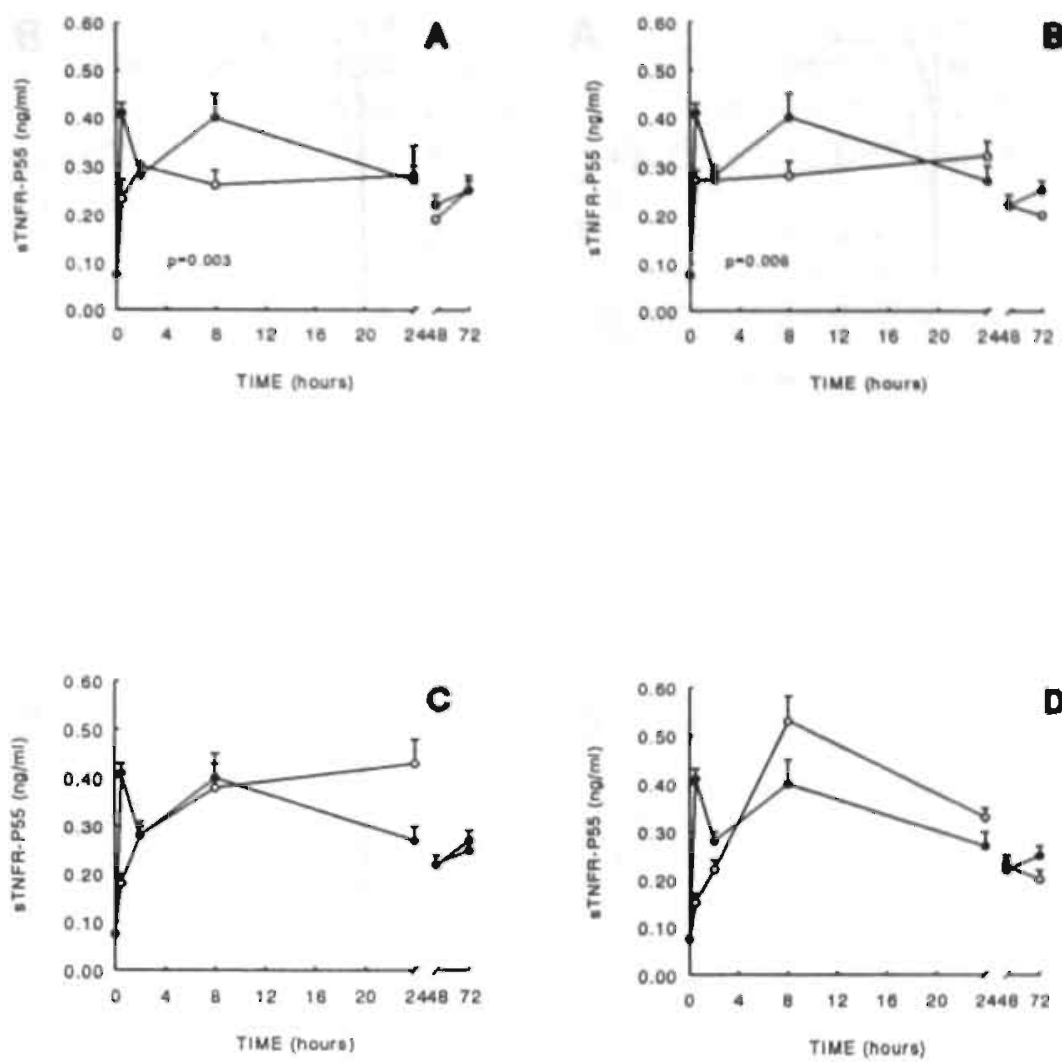

Figure 4: sTNFR-P55 levels after anti-CD3 injection with or without pretrealment. Mice were challenged with $50 \mu \mathrm{g}$ of $145-2 \mathrm{C} 11$ without pretreatment (closed circles) or after pretreatment (all showed as open circles) with either anti-TNF mAb $(750 \mu \mathrm{g})($ panel A), anti-IFN- $\gamma \mathrm{mAb}(100 \mu \mathrm{g})(\mathrm{panel}$ B), PTX (2mg)(panel C), or m-PDS (1mg)(panel D). Data are expressed as means \pm SEM for 6 mice at each time point. 

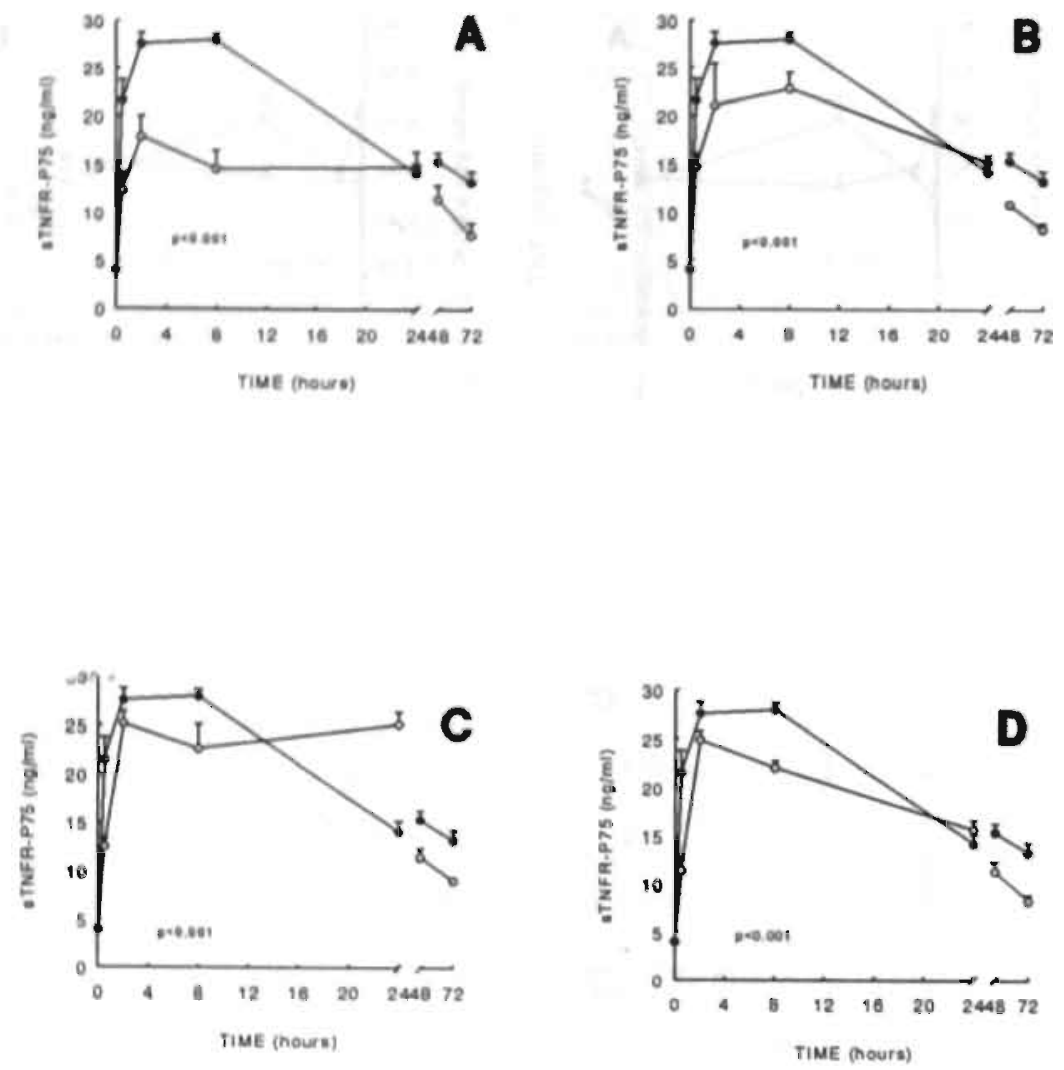

Figure 5. STNFR-P75 levels after anti-CD3 injection with or without pretreatment. Mice were challenged with $50 \mu \mathrm{g}$ of $145-2 \mathrm{CII}$ without pretreatment (closed circles) or after pretreatment (all showed as open circles) with either anti-TNF mAb $(750 \mu g)($ panel A), anti-IFN- $\gamma$ mAb $(100 \mu g)($ panel B), PTX (2mg)(panel C), or m-PDS (1mg)(panel D). Data are expressed as means \pm SEM for 6 mice at each time point. 


\section{Discussion}

The 145-2C11 mAb directed against the CD3 complex of murine T-lymphocytes shares with OKT3 the property to activate T-cells in vivo and in vitro $(13,14,27-31)$. T-cell activation has been demonstrated to be accompanied by release of several cytokines such as TNF $(16,18,19,27,31-33)$. In this study, we demonstrate in a murine model that injection of the mAb 145-2C11 also induces the release of both sTNFR-P55 and STNFR-P75 in the circulation.

Our data first show that release of TNF and sTNFR after anti-CD3 is dose dependent. In addition, high doses of the antibody led to prolonged increase in TNF and STNFR. These data are in accordance with a previous report describing dose dependence of $\mathrm{T}$ cell activation by anti-murine CD3 (30).

Comparison of kinetics of sTNFR levels after anti-CD3 with those obtained after LPS injection (10), show that with both agents sTNFR-P55 levels peaked as soon as $30 \mathrm{~min}$ after injection, but in anti-CD3 treated mice sTNFR-P55 levels remained high up to 8 hours. The maximum levels of sTNFR-P55 after anti-CD3 in the circulation were however similar to those observed after LPS injection, as we reported before. Baseline levels of sTNFR-P75 levels $(4-5 \mathrm{ng} / \mathrm{ml})$ are approximately 50-60 times higher than baseline levels of sTNFR-P55 $( \pm 75 \mathrm{pg} / \mathrm{ml})(10)$. This in contrast to the situation in man where similar levels for sTNFR-P55 and sTNFR-P75 levels are present (7). After LPS as well as after anti-CD3 administration, sTNFR-P75 levels increased rapidly before the actual TNF increase and remained high up to 8 hours, although maximal levels reached after LPS injection were higher (10).

In a previous study, it was shown that TNF can induce sTNFR release in vivo (10). In line with this observation, we studied whether TNF released in response to anti-CD3 is responsible for the observed release of sTNFR. Therefore, we injected mice with an anti-TNF mAb (TN3) or with PTX, a methylxanthine which is known for its anti-TNF properties (34). The data obtained show that both agents significantly reduced TNF levels. While TN3 reduced also both sTNFR levels, PTX only affected sTNFR-P75 levels, although in both cases sTNFR levels were still significantly higher compared to baseline levels. A possible explanation for these observations could be the fact that TN3 is a more potent anti-TNF agent. The effect of TN3 on sTNFR release by antiCD3 injection is clearly different from the effect of TN3 on LPS induced sTNFR release. In the latter TN3 in contrast enhanced sTNFR-P55 levels without affecting sTNFR-P75 levels compared to the LPS control group. These differences indicate that the induction mechanisms for STNFR release are not identical in both models. It appears that TNF plays a negligible role in the LPS model, whereas in the anti-CD3 model however, a minor role for TNF can not be excluded, since STNFR levels were reduced when TNF levels were reduced.

As anti-CD3 not only results in the release of TNF but also in the release of IFN- $\gamma$ (32), we studied the effects of anti-IFN- $\gamma$ pretreatment. MAb pretreatment reduced next to TNF levels also levels of both sTNFR after anti-CD3 injection. The reduction in 
TNF levels and in sTNFR-P55 levels is in line with the effects of anti-IFN- $\gamma$ after LPS injection where a reduction of systemic TNF levels was seen together with a minor decrease in sTNFR-P55 levels (10). However, in the LPS model anti-IFN- $\gamma$ resulted in substantially and significantly increased sTNFR-P75 levels compared to LPS controls, which strengthens the fact that STNFR-P75 regulation is different in both models.

Steroids, agents that are routinely used in man to attenuate the side effects consecutive to the first injections of OKT3, are shown to efficiently reduce TNF levels and sTNFRP75 levels which is in line with its inhibitory effect on T-cell activation and cytokine release. Paradoxically, steroids lacked an effect on sTNFR-P55 levels, for which we have no explanation.

The physiological meaning of enhanced sTNFR levels is considered to constitute a protective mechanism against circulating TNF. Taken into account the $\mathrm{Kd}$ of murine STNFR-P55 of $200 \mathrm{pM}$ and the concentration of circulating TNF of approximately 10 $\mathrm{ng} / \mathrm{ml}$, sTNFR-P55 levels seem to be of little importance for inactivation of TNF $(1,35)$. However, peak levels of sTNFR-P75 up to $30 \mathrm{ng} / \mathrm{ml}$ could, taking into account the Kd of the mTNFR-P75 of $50 \mathrm{pM}$, by complex formation lead to a very substantial reduction of free bioactive circulating TNF, and facilitate the clearing of TNF by the kidneys (1). Therefore, it is of interest that steroids reduce TNF levels by more than $65 \%$, but only minimally affected the levels of STNFR. Since in a previous report it was shown that steroids given before anti-CD3 injection not only reduced TNF levels, but also IFN- $\gamma$, IL- 6 and IL-2 levels, the relatively unaffected sTNFR levels could provide a substantial buffer for TNF inactivation which, together with the reduced cytokine levels could contribute to the significantly reduced anti-CD3 induced side effects.

In conclusion, our data show that not only LPS and TNF but also T-cell activation via anti-CD3 results in the release of STNFR. This observation is in line with the presence of TNF and sTNFR in other T-celi mediated diseases such as RA (5). The mechanism of sTNFR release differs between the anti-CD3 model and the LPS model, since the effects of pretreatment of the mice with anti-IFN- $\gamma$ or TN3 were clearly distinct. The results obtained show that TNF is not a crucial factor in sTNFR release induced by anti-CD3, although a minor role can not be excluded. The nature of the cells involved in TNF and sTNFR release are not yet identified but in vitro data indicate that both T. cells, neutrophils and macrophages might be involved (2-5). The mechanism by which sTNFR release in vivo is regulated requires further investigation. 


\section{References}

1. Bemelmans, M.H.A., D.J. Gouma, and W.A. Buurman. Influence of nephrectomy on Tumor Necrosis Factor clearance in a murine model. J. Immunol. 1993;150:2007-2017.

2. Porteu, F., M. Brockhaus, D. Wallach, H. Engelmann, and C. Nathan. Human neutrophil elastase releases a ligand-binding fragment from the $75-\mathrm{kDa}$ Tumor Necrosis Factor (TNF) receptor. J. Biol. Chem. 1991;266:18846-18853.

3. Porteu, F., and C. Nathan. Shedding of tumor necrosis factor by activated human neutrophils. J. Exp. Med. 1990;172:599-607.

4. Ding, A.H., and F. Porteu. Regulation of Tumor Necrosis Factor receptors on phagocytes. P. Soc. Exp. Biol. Med. 1992;200:458-465.

5. Cope, A.P., D. Aderka, M. Doherty, H. Engelmann, D. Gibbons, A.C. Jones, F.M. Brennan, R.N. Maini, D. Wallach, and M. Feldmann. Increased levels of soluble Tumor Necrosis Factor receptors in the sera and synovial fluid of patients with rheumatic diseases. Arthritis Rheum. 1992;35:1160-1169.

6. Van Zee, K.J., T. Kohno, E. Fischer, C.S. Rock, L.L. Moldawer, and S.F. Lowry. Tumor Necrosis Factor soluble receptors circulate during exerimental and clinical inflammation and can protect against excessive Tumor Necrosis Factor $\alpha$ in vitro and in vivo. Proc. Natl. Acad. Sci. $1992 ; 89 ; 4845-4849$.

7. Spinas, G.A., U. Keller, and M. Brockhaus. Release of soluble receptors for Tumor Necrosis Factor (TNF) in relation to circulating TNF during experimental endotoxemia. J. Clin. Invest. 1992;90:533-536.

8. Andus, T., V. Gross, A. Holstege, M. Ott, M. Weber, M. David, H. Gallati, W. Gerok, and J. Scholmerich. High concentrations of soluble Tumor Necrosis Factor receptors in ascites. Hepatolgy 1992;16:749-755.

9. Aderka, D., H. Engelmann, V. Homik, Y. Skornick, Y. Levo, D. Wallach, and G. Kushtai. Increased senum levels of soluble receptors for Tumor Necrosis Factor in cancer patients. Cancer Res. 1991;51:5602-5607.

10. Bemelmans, M.H.A., D.J. Gouma, and W.A. Buurman. L.PS induced sTNF-Receptor release in vivo in a murine model: investigation of the role of TNF, IL-1, LIF, and IFN- $\gamma$. J. Immunol. 1993;151:5554-5562.

11. Imagawa, D.K., J.M. Millis, P. Seu, K.M. Olthof, J. Hart, E. Wasef, R.A. Dempsey, S. Stevens, and R.W. Busuttil. The role of Tumor Necrosis Factor in allograft rejection. Transplantation 1991:51:57-62.

12. Tsuchida, A., H. Salem, N. Thompson, and W.W. Hancock. Tumor Necrosis Factor production during human renal allograft rejection is associated with depression of plasma protein $\mathrm{C}$ and free protein $\mathrm{S}$ levels and decreased intragraft thrombomodulin expression. I. Exp. Med. 1992:175:81-90.

13. Chatenoud, L., C. Ferran, C. Legendre, I. Thouard, S. Merite, A. Reuter, Y. Gevaert, H. Kreis, P. Franchimont, and J.F. Bach. In vivo cell activation following OKT3 administration. Transplantation 1990:49:697-702.

14. Urra, J.M., R. Peces, E. Martinez-Naves, V. Gutierrez, F. Setien, and C. Lopez-Larrea. Tumor Necrosis. Factor $\alpha$ is released by monocytes in OKT3 monoclonal antibody immunosuppressive therapy. Transpl. Proc. 1992;24:2542-2544.

15. Sheehan, K.C.F., N.H. Ruddle, and R.D. Schreiber. Generation and characterization of hamster monoclonal antibodies that neutralize murine Tumor Necrosis Factors. J Immunol. 1989;142:3884-3893.

16. Ferran, C., M. Dy, K. Sheehan, R. Schreiber, G. Grau, J. Bluestone, J.F. Bach, and L. Chatenoud. Cascade modulation by anti-tumor necrosis factor antibody of interferon- $\gamma$. 
interleukin-3 and interleukin- 6 release after triggering of the CD3/T cell receptor activation pathway. Eur. J. Immunol.1991:21:2349-2353.

17. Heremans, H., C. Dillen, R. Dijkmans, G. Grau, and A. Billiau. The role of cytokines in various animal models of inflammation. Lymphokine Res. 1989;8:329-333.

18. Alegre, M.L., K. Gastaldello, D. Abramowicz, P. Kinnaert, P. Vereerstraeten, L. de Pauw, P. Vandenabeele, M. Moser, O. Leo, and M. Goldman. Evidence that pentoxifylline reduces antiCD3 monoclonal antibody-induced cytokine release syndrome. Transplantation 1991;52:674. 679.

19. Alegre, M.L., P. Vandenabeele, M. Depierreux, S. Floquin, M. Deschodt-Lanckman, V. Flamand, M. Moser, O. Leo, J. Urbain, W. Fiers, and M. Goldman. Cytokine release syndrome induced by the 145-2C11 anti-CD3 monoclonal antibody in mice: Prevention by high doses of methylprednisolone. J. Immunol. 1991;146:1184-1191.

20. Selkurt, E.E. Measurement of renal blood flow. Meth. Med. Res. 1948:1:191-199.

21. Dejong, C.H.C., M.T. Kampman, N.E.P. Deutz, and P.B. Soeters. Altered glutamine metabolism in rat portal drained viscera and hindquarter during hyperammonemia. Gastroenterology 1992:102:936-948.

22. Rose, B.D. Clinical physiology of acid-base and electrolyte disorders. 1977. Mc Graw-Hill Kogakusha LTD, Tokyo, 548 pp.

23. Dentener, M.A., J.W. Greve, J.G. Maessen, and W.A. Buurman. Role of tumor necrosis factor in the phenomenon of the enhanced sensitivity of animals to endotoxin after exposure to lead. Immunopharmacol, and Immunotoxicol, 1989;11:321-324.

24. Espevik, T., and J. Nissen-Meyer. A highly sensitive cell line, WEHI 164 clone 13, for measuring cytotoxic factor /tumor necrosis factor from human monocytes. J. Immunol. Methods. 1986;95:99-105.

25. Hanssen, M.B., S.E. Nielsen, and K. Berg. Re-examination and further development of a precise and rapid dye method for measuring cell growth/cell kill. J. Immunol. Methods. 1989;119:203-210.

26. Norusis, M.J. ed. SPSS/PC+ V3.1 Base Manual for the IBM PC/XT/AT and PS/2. SPSS Inc., 1988. Chicago, USA.

27. Alegre, M., P. Vandenabeele, V. Flamand, M. Moser, O. Leo, D. Abramowicz, J. Urbain, W. Fiers, and M. Goldman. Hypothermia and hypglycemia induced by anti-CD3 monoclonal antibody in mice: role of tumor necrosis factor. Eur. J. Immunol. 1990;20:707-710.

28. Caillat-Zucman, S., N. Blumenfeld, C. Legendre, L.H. Noel, J.F. Bach, H. Kreis, and L. Chatenoud. The OKT3 immunosuppressive effect. Transplantation 1990;49:156-160.

29. Ferran, C., M. Dy, S. Merite, K. Sheehan, R. Schreiber, F. Leboulenger, P. Landais, J. Bluestone, J.F. Bach, and L. Chatenoud. Reduction of morbidity and cytokine release in antiCD3 MoAb-treated mice by corticosteroids. Transplantation. 1990;50:642-648.

30. Ellenhorn, J.D.j., R. Hirsch, J.P. Hartly, and J.A. Bluestone. Dose-dependent activation of murine T-cells following in vivo administration of anti-murine CD3. Transpl. Proc, 19889; 21:1013-1014.

31. Debets, J.M.H., K.M.L. Leunissen, H.J. van Hooff, C.J. van der Linden, and W.A. Buurman. Evidence of involvement of tumor necrosis factor in adverse reactions during treatment of kidney allograft rejection with antithymocyte globulin. Transplantation 1989;47:487-492.

32. Abramowicz. D., L. Schandene, M. Goldman, A. Crusiaux, P. Vereerstraeten, L. De Pauw, J. Wybran, P. Kinnaert, E. Dupont, and C. Toussaint. Release of tumor necrosis factor, interleukin-2, and gamma-interferon in serum after injection of OKT3 monoclonal antibody in kidney transplant recipients. Transplantation 1989:47:606-608.

33. Charpentier, B., C. Hiesse, O. Lantz, C. Ferran, S. Stevens, D. O'Shaugnessy, M. Bodmer, G. Benoit. J.F. Bach, and L. Chatenoud. Evidence that antihuman Tumor Necrosis Factor monoclonal antibody prevents OKT3-induced acute syndrome. Transplantation 1992,954:997. 
34. Schandene, P., P. Vandenbussche, A. Crusiaux, M.L. Alegre, D. Abramowicz, E. Dupont, J. Content, and M. Goldman. Differential effects of pentoxifylline on the production of tumour necrosis factor-alpha (TNF- $\alpha$ ) and interleukin- 6 (IL- 6 ) by monocytes and T-cells. Immunology 1992;76:30-34.

35. Lewis, M., L.A. Tartaglia, A. Lee, G.L. Benett, G.C. Rice, G.H.W. Wong, E.Y. Chen, and D.V. Goeddel. Cloning and expression of cDNAs for two distinct murine tumor necrosis factor receptors demonstrate one receptor is species specific. Proc. Natl. Acad. Sci. USA. 1991;88:2830-2834. 



\section{Chapter 10}

INCREASED PLASMA LEVELS OF SOLUBLE TUMOR NECROSIS FACTOR RECEPTORS IN SEPSIS SYNDROME: CORRELATION WITH PLASMA CREATININE

A.H.M. Froon, M.H.A. Bemelmans, J.W. Greve, C.J. van der Linden, W.A. Buurman. Crit. Care. Med., in press. 


\section{Abstract}

Tumor Necrosis Factor (TNF) is an important mediator in the complex pathophysiology of sepsis syndrome. Although a positive correlation with mortality has been demonstrated, TNF has not been found consistently in sepsis. Since prolonged elevations in soluble TNF receptor levels were demonstrated after endotoxin and TNF administration, it was investigated here whether the measurement of TNF receptor levels could provide a better parameter of disease compared to plasma TNF and Interleukin-6 (IL-6) levels.

Design: Prospective analysis.

Setting: General ICU of a University Hospital.

Patients: Patients with sepsis syndrome and proven bacteremia.

Results: Plasma peak levels of the soluble 55kD molecular weight TNF receptor were significantly higher $(\mathrm{P}<.005)$ in nonsurvivors compared to survivors of sepsis syndrome, whereas the difference in peak levels of the soluble $75 \mathrm{kD}$ TNF receptor did not reach significancy $(\mathrm{P}=, 06)$. In contrast to TNF peak levels $(\mathrm{P}=.14)$, significantly higher IL-6 peak levels were measured in nonsurvivors $(\mathrm{P}<.05)$. Besides the positive conrelation between the soluble 55kD TNF receptor and the soluble $75 \mathrm{kD}$ TNF receptor $\left(r^{2}=68 ; \mathrm{P}<0001\right)_{i}$ peak leyels of both soluble $55 \mathrm{kD}$ and $75 \mathrm{kD}$ TNF receptor correlated significantly with plasma creatinine, an indicator of renal function $\left(\mathrm{r}^{2}=.60 ; \mathrm{P}<.0001\right.$ and $\mathrm{r}^{2}=.44 ; \mathrm{P}<.001$, respectively). Plasma creatinine levels were significantly higher in nonsurvivors $(\mathrm{P}<.001)$.

Conclusions: In the population studied, plasma soluble TNF receptor levels correlated with outcome as well as with plasma creatinine levels. The data presented suggest that increased plasma soluble TNF receptor levels in sepsis syndrome are merely the result of renal failure complicating sepsis, and are likewise correlated with mortality.

\section{Introduction}

Tumoi Necrosis Factor (TNF) is a cytokine primarily secreted by mononuclear phagocytes and is considered to play an important role in the metabolic and hemodynamic alterations seen in endotoxemia (1-3). Evidence for the involvement of TNF in the pathophysiology of sepsis was obtained in animal studies (4) as well as in volunteer studies (5). Moreover, prophylactic administration of anti-TNF antibodies reduced the lethality after induced endotoxemia (6) and gram-negative bacteremia (7) in animal models.

TNF has been demonstrated to play an important role in the defense against infections (8). However, high plasma levels of TNF as seen in endotoxemia are considered to be harmful and can lead to organ failure and death (9). Although a positive correlation between plasma TNF and mortality has been demonstrated in sepsis syndrome (9-11) and meningococcal sepsis (12), this correlation has not been found consistently $(13,14)$. In plasma both $55 \mathrm{kD}$ and $75 \mathrm{kD}$ molecular weight soluble TNF receptors are able to 
affect the detection of TNF in some assays by complexing TNF (15). The inconsistency in observed TNF data can be explained by differences between assays in the ability to detect TNF complexed to the TNF receptor. In addition, the short half life of TNF (16) makes detection dependent on frequency of sampling.

The measurement of TNF induced factors with slower kinetics (Interleukin-6, soluble TNF receptors) may offer better opportunities to assess the severity of disease. For Interleukin-6 (IL-6) a positive correlation with mortality has been reported $(16,17)$. Since increased soluble TNF receptor levels were detected after TNF (18) and endotoxin administration in humans $(19,20)$, soluble TNF receptor levels appeared to reflect TNF induced inflammation, and could therefore be useful as a parameter of disease. The exact function of soluble TNF receptors is thus far not known. However, soluble TNF receptors have been demonstrated to bind and to inactivate TNF. Although elevations in soluble TNF receptor levels have been demonstrated in inflammation, impaired renal clearance of soluble TNF receptor as in chronic renal failure also leads to increased soluble TNF receptor levels (21).

In this study the hypothesis was investigated whether soluble TNF receptor plasma levels are a more useful parameter to asses the severity of disease compared to plasma TNF and IL-6 levels. Therefore soluble TNF receptor levels were determined in patients that fulfilled the criteria of sepsis syndrome in combination with a positive blood culture. Results were correlated with mortality and plasma creatinine levels.

\section{Materials and Methods}

Patient selection. All patients admitted to the general intensive care unit (ICU) of the University Hospital of Maastricht are registered prospectively. A registration system is used, composed of the following parts: the Apache II score (22); the "grading of sepsis score" (23); daily registration of sepsis syndrome parameters (24) (Table 1); registration of positive bacterial cultures; and daily blood sampling for cytokine measurements.

This ICU patient database was used to select the patient population studied. Patients were included if they fulfilled the criteria of sepsis syndrome in combination with a positive blood culture. One or more plasma samples had to be available for the determination of inflammatory mediators. Patients with pre-existing severe organ failure (including chronic renal failure) were excluded from the study. The study was reviewed and approved by our Institutional Review Board, which deemed that informed consent was not required.

Blood samples. From the day of ICU admission, blood samples were taken daily from each patient and collected in tubes containing ethylenediaminetetraacetic (EDTA). Daily blood samples were always collected together with the first daily round of routine blood sampling at approximately $6 \mathrm{AM}$. The blood samples were immediately put on ice and plasma was prepared at $4{ }^{\circ} \mathrm{C}$ by centrifugation at $3000 \mathrm{rpm}$ for 5 
minutes. Samples were stored at $-70^{\circ} \mathrm{C}$ until use. Levels of TNF, $\mathrm{L}-6$, and both the soluble $55 \mathrm{kD}$ and $75 \mathrm{kD}$ TNF receptor were determined as described below. Since plasma samples were collected prospectively, the above mentioned levels were determined in plasma samples collected for 7 days (from 3 days before up to 3 days after study entry). In patients fulfilling the inclusion criteria at ICU admission, no pre-sepsis samples were available. The highest cytokine/receptor levels measured in each patient, further designated as peak levels, were correlated with mortality.

Table 1. Definition of sepsis syndrome*

\section{obligatory sepsis criteria:}

Clinical evidence of infection

Fever or hypothermia: temperature $>38.3$ or $<35.6{ }^{\circ} \mathrm{C}$

Tachycardia: $>90$ beats per min

Tachypnoea: $>20$ breaths per min or the requirement of mechanical ventilation

\section{and either hypotension:}

Systolic blood pressure $\leq 90 \mathrm{~mm} \mathrm{Hg}$ or a sustained drop in systolic pressure $>40 \mathrm{~mm} \mathrm{Hg}$

\section{or 2 or more of the 6 following signs}

of systemic toxiclty or peripheral hypoperfusion:

Hypoxemia: $\mathrm{PaO}_{2} \leq 75$ torr $\left(\leq 10 \mathrm{kPa}\right.$ ) or $\mathrm{PaO}_{2} / \mathrm{FiO}_{2} \leq 250$

Metabolic acidosis: $\mathrm{pH}<7.3$ or base deficit $>5 \mathrm{mmol} / \mathrm{L}$ or elevated plasma lactate level

Acute renal failure: urinary output $<0.5 \mathrm{~mL} / \mathrm{kg}$ body weight/hour

Quick $>1.5 \times$ normal value or APTT $>1.2 \times$ normal value or platelet count $<10010^{9} / \mathrm{L}$

or $<50 \%$ of the baseline value

Sudden decrease in mental aquity

Cardiac index $>4 \mathrm{~L} / \mathrm{min} / \mathrm{m}^{2}$ with systemic vascular resistance $<800$ dyne sec $/ \mathrm{cm}^{5}$

* definition of sepsis syndrome similar as proposed by Bone (24)

Assays. Plasma TNF concentrations were determined ușing an enzyme-linked immunosorbent assay (ELISA) developed in our laboratory, which correlates well with TNF detected by bioassay $(15,25)$. In short, samples and the standard titration curve (recombinant TNF kindly provided by BASF/Knoll, Ludwigshafen, FRG) were incubated with a murine anti-human TNF mAb $61 \mathrm{E} 71$ absorbed to a microtiter plate (Nunc, Roskilde, Denmark). Subsequently the plates were incubated with a polyclonal rabbit anti-human TNF antiserum, followed by a peroxidase conjugated goat anti-rabbit-IgG (Jackson, Westgrove, PA) and substrate (O-phenyldiamine, Sigma, St. Louis, $\mathrm{MO}$ ). Optical density was read, and TNF concentrations were calculated from the standard TNF curve. The detection limit for TNF was $20 \mathrm{pg} / \mathrm{mL}$.

Plasma IL- 6 concentrations were determined in a procedure largely parallel to the TNF ELISA mentioned above. As capture antibody the murine anti-human IL-6 antibody 5EI (developed in our laboratory) was used. Plasma samples and the standard titration 
curve with recombinant IL-6 (kindly provided by Prof. Dr. W. Sebald, Würzberg, FRG) were added to the plates and subsequently incubated with polyclonal rabbit anti-IL-6 antiserum followed by peroxidase conjugated goat anti-rabbit-IgG. Substrate was added, and optical density was read. The detection limit for $\mathrm{IL}-6$ was $10 \mathrm{pg} / \mathrm{mL}$. In order to detect and to quantify TNF receptors, the microtiter plates were coated with TNF receptor antibodies (htr-20 and utr-4 for the $55 \mathrm{kD}$ and $75 \mathrm{kD}$ TNF receptor, respectively) as has been described before (26). Plasma samples and peroxidase labeled TNF were added and incubated simultaneously. During the incubation period the human TNF receptor present in the samples binds with both the immobilized anti-human TNF receptor antibodies and the human TNF-peroxidase conjugate. Thereafter the unbound material is eliminated through a washing step, and the quantity of bound peroxidase determined enzymatically through the addition of substrate. The color intensity was read, and the quantity of human TNF receptor in the samples calculated from the standard curve with the soluble $55 \mathrm{kD}$ and $75 \mathrm{kD}$ TNF receptor, respectively. Detection limit for both the soluble $55 \mathrm{kD}$ and $75 \mathrm{kD}$ TNF receptor was $100 \mathrm{pg} / \mathrm{mL}$. All reagents for the soluble TNF receptor assay (htr-20, utr-4, peroxidase labeled TNF, soluble 55kD TNF receptor, and soluble $75 \mathrm{kD}$ TNF receptor) were kindly provided by Drs. H. Gallati and M. Brockhaus, Hoffmann-La Roche, Basel, Switzerland. Creatinine levels were determined as described previously (27).

Statistical analysis. Cytokine/receptor data are shown as peak levels, and in each patient group (survivors and nonsurvivors) mean peak value \pm SEM are given. Mann-Whitney test was used for statistical analysis of the data. Differences were considered significant at $\mathrm{P}<.05$. Correlations between plasma creatinine and soluble TNF receptor peak levels were analyzed by using Spearman's rank correlation test.

\section{Results}

Patients. Between January 1991 and March 1992, 516 patients were admitted at the ICU (Table 2). On admission or later during their stay on the ICU, 28 patients fulfilled the inclusion criteria. Patients of which blood samples were available ( $n=26 ; 14$ female, 12 male) were included in the study (range 1 to 7 blood samples). Their ages ranged from 33 to 91 years (mean age $63 \pm 2.9$ years (SEM)). A gram-negative bacteremia was found in 10 patients, a gram-positive blood culture in 11 patients, and a mixed bacteremia in 5 patients.

The study population was divided in 2 groups according to survival of sepsis syndrome. The first group ( $\mathrm{n}=10$ ) consisted of nonsurvivors; patients deceased in ICU within 30 days after sepsis syndrome was diagnosed. Patients alive at day 30 or patients discharged from ICU $(n=16)$ were classified as survivors. The ICU mortality rate at day 30 was $38 \%(n=10)$ and the final hospital mortality rate $62 \%(n=16)$. 
Table 2. Patient selection

Patients admitted to ICU 1991-1992.

Patients fulfilled sepsis syndrome criteria

Sepsis syndrome and positive blood culture

After excluding long-term hemodialysis patients

Patients of which plasma samples were available

Correlation of Tumor Necrosis Factor and Interleukin- 6 with Mortality. In 3 of the 10 nonsurvivors biologically active TNF could not be detected. Although the highest TNF peak levels were found in nonsurvivors, the difference in TNF peak levels between survivors and nonsurvivors was not significant $(\mathrm{P}=.14)$. Mean TNF peak levels were $80 \pm 30 \mathrm{pg} / \mathrm{mL}$ and $185 \pm 65 \mathrm{pg} / \mathrm{mL}$ in survivors and nonsurvivors, respectively (fig 1 , left).

In contrast to TNF, plasma IL-6 peak. levels were significantly higher in nonsurvivors $(\mathrm{P}<-05)$. Although IL-6 could not be detected in 2 of the 10 nonsurvivors, the highest IL-6 peak levels were found in this group with a mean peak level of $9.6 \pm 3.0 \mathrm{ng} / \mathrm{mL}$. Moreover, 6 out of 7 patients with plasma IL 6 peak levels exceeding $3 \mathrm{ng} / \mathrm{mL}$ died, whereas 15 out of 19 patients with IL-6 peak levels less than $3 \mathrm{ng} / \mathrm{mL}$ survived. In survivors mean IL-6 peak level was $1.0 \pm 0.5 \mathrm{ng} / \mathrm{mL}$ (fig 1 , right).
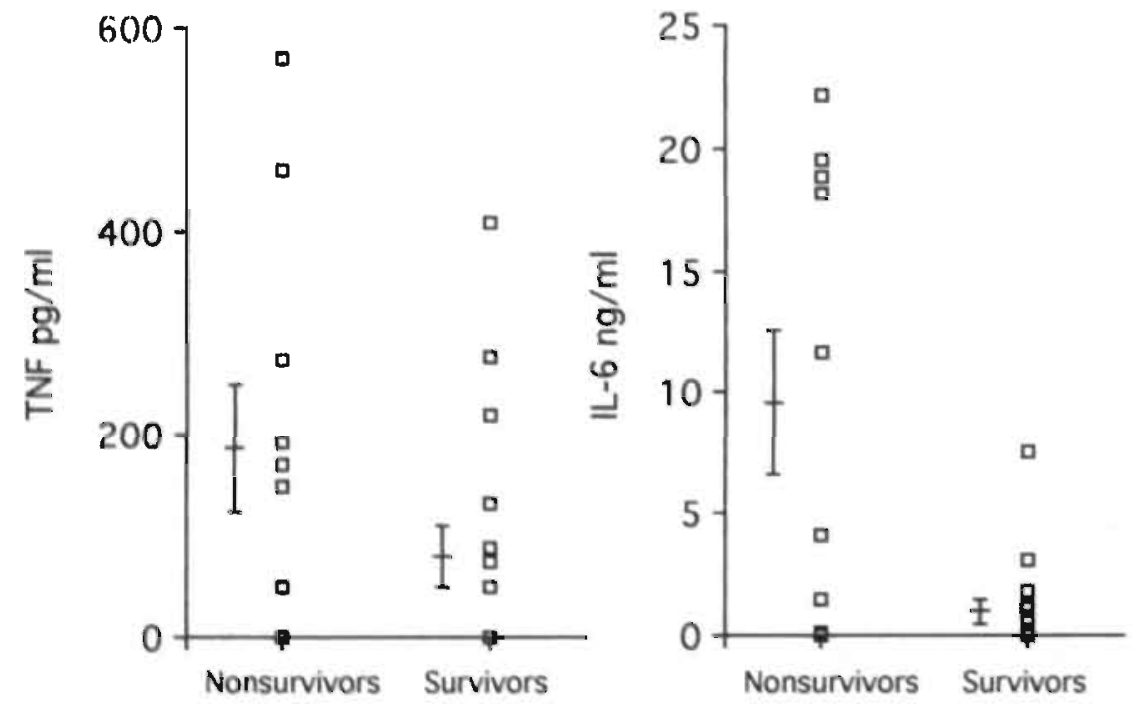

Figure 1: Cytokine peak levels in sepsis syndrome.

The difference in plasma TNF peak levels (left) between survivors $(n=16)$ and nonsurvivors $(n=10)$ was not significant. $(P=14)$, whereas plasma IL-6 peak levels (right) were significantly higher in nonsurvivors $(\mathrm{P}<.05)$. The error bar in each patient group represents the mean peak value $\pm \mathrm{SEM}$. 
Correlation of Soluble TNF Receptor Plasma Levels with Mortality. Both soluble 55kD and $75 \mathrm{kD}$ TNF receptors were detected in all plasma samples tested and a positive correlation between the soluble $55 \mathrm{kD}$ TNF receptor and soluble $75 \mathrm{kD}$ TNF receptor was found $\left(r^{2}=.68 ; \mathrm{P}<.0001\right)$. Soluble $55 \mathrm{kD}$ TNF receptor peak levels were significantly higher in nonsurvivors of sepsis syndrome compared to survivors $(\mathrm{P}<.005)$. Mean soluble $55 \mathrm{kD}$ TNF receptor peak levels were $12.2 \pm 1.6 \mathrm{ng} / \mathrm{mL}$ (range $3.4-20.5 \mathrm{ng} / \mathrm{mL}$ ) and $5.2 \pm 1.0 \mathrm{ng} / \mathrm{mL}$ (range $1.5-13.3 \mathrm{ng} / \mathrm{mL}$ ) in nonsurvivors and survivors, respectively (fig 2, left). Similar data were found for soluble $75 \mathrm{kD}$ TNF receptor peak levels (fig 2 , right). In nonsurvivors mean soluble $75 \mathrm{kD}$ TNF receptor peak level was $11.3 \pm 1.8$ $\mathrm{ng} / \mathrm{mL}$ and in survivors $6.6 \pm 1.2 \mathrm{ng} / \mathrm{mL}$. The difference between survivors and nonsurvivors however, was not significant $(\mathrm{P}=.06)$.
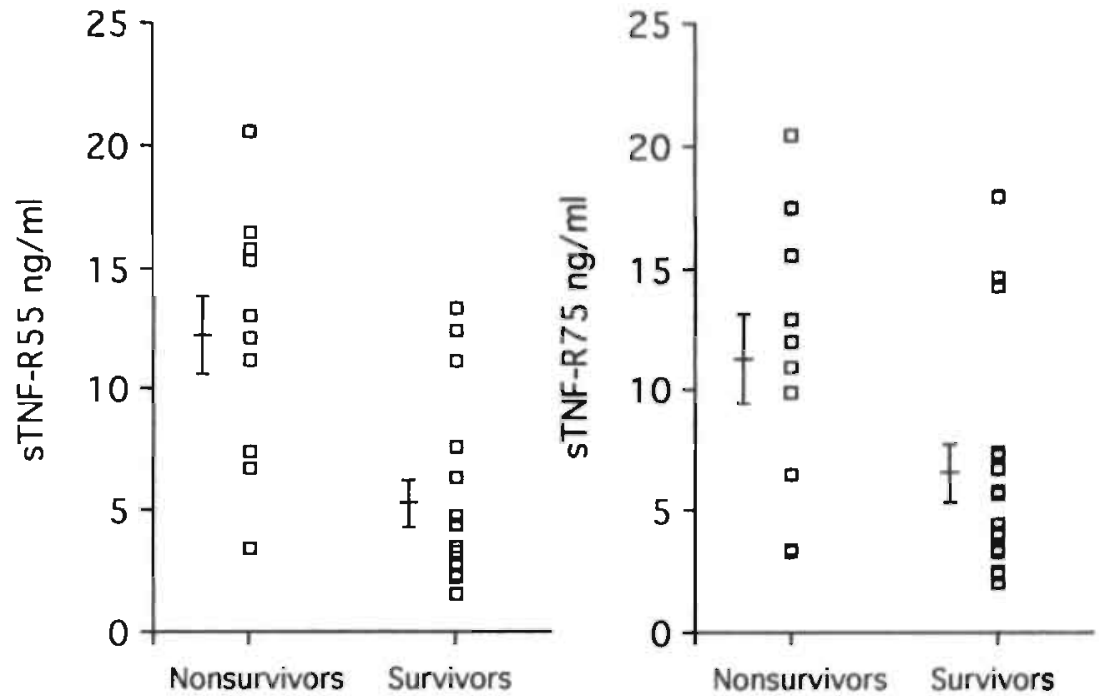

Figure 2: soluble TNF receptor peak levels in sepsis syndrome.

In contrast to soluble 75kD TNF receptor peak levels (right), soluble 55kD TNF receptor peak levels (left) were significantly higher in nonsurvivors $(n=10)$ compared to survivors $(n=16)(\mathbb{P}=0.06$ and $\mathrm{P}<.005$, respectively). The error bar in each patient group represents the mean peak value $\pm \mathrm{SEM}$.

Correlation between Plasma Creatinine and Plasma soluble TNF receptor Levels. As a parameter, although not absolute, of renal function, plasma creatinine levels were measured and correlated with soluble TNF receptor levels (fig 3 ). The data showed a significant correlation between both soluble $55 \mathrm{kD}$ and $75 \mathrm{kD}$ TNF receptor peak levels and corresponding plasma creatinine levels $\left(r^{2}=.60 ; \mathrm{P}<.0001\right.$ and $r^{2}=.44 ; \mathrm{P}<.001$, respectively). 

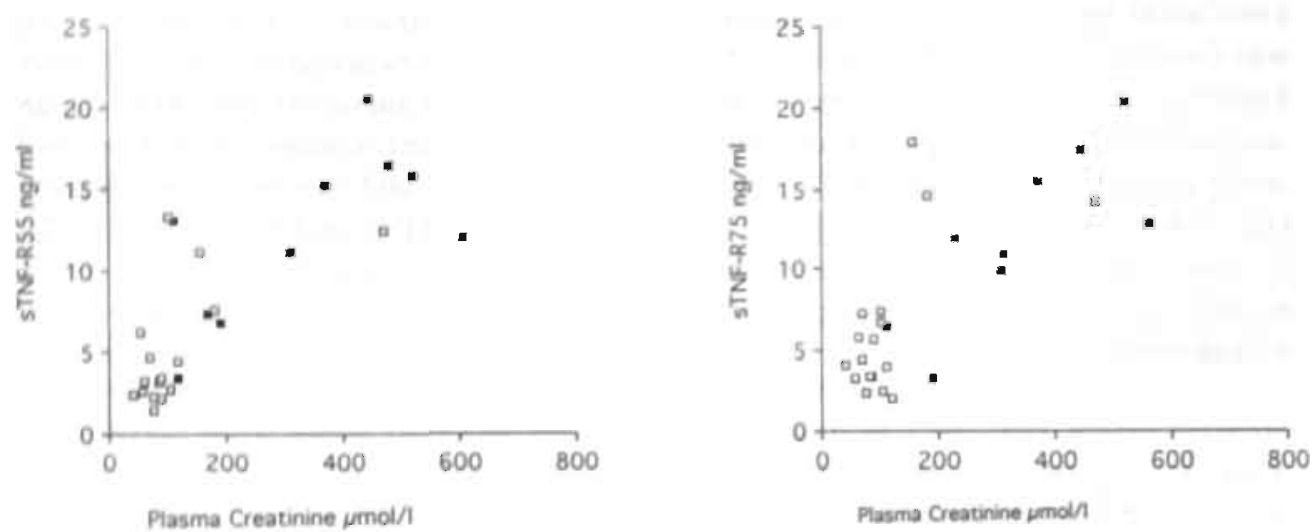

Fisure 3. Correlation between soluble TNF receptor peak levels and plasma creatinine in sepsis syndrome. Both soluble 55kD TNF receptor (left) and soluble $75 \mathrm{kD}$ TNF receptor (right) peak levels correlated significantly with corresponding plasma creatinine levels: $r^{2}=.60 ; P<.0001$ and $r^{2}=.44$; $P<, 001$, respectively (survivors $n=16$; nonsurvivors $n=10$ ).

Table 3. Plasma creatinine peak levels in sepsis syndrome and ICU mortality*

\begin{tabular}{lll}
\hline & Plasma Creatinine & Plasma Creatinine \\
& $\leq 150 \mu \mathrm{mol} / \mathrm{L}$ & $>150 \mu \mathrm{mol} / \mathrm{L}$ \\
Survivers $(\mathrm{n}=16)$ & 12 & 4 \\
Nonsurvivors $(\mathrm{n}=10)$ & 1 & 9 \\
& & \\
\hline
\end{tabular}

* Plasma creatinine peak levels exceeding $150 \mu \mathrm{mol} / \mathrm{L}$ correlated significantly with mortality. Chi-Square: $\mathrm{P}<.005$.

\section{Discussion}

Several inflammatory mediators involved in the pathophysiology of the sepsis syndrome are reported to be associated with fatal outcome (e.g. IL-6, TNF). Since plasma TNF levels were not detected consistently in sepsis, it was investigated here whether the measurement of soluble TNF receptor levels provides a better parameter of disease. Both soluble $55 \mathrm{kD}$ TNF receptor and soluble $75 \mathrm{kD}$ TNF receptor levels were measured and results were correlated with mortality and compared with TNF and IL-6 data. 
In the present study 6 out of 7 patients with plasma IL-6 peak levels exceeding 3 $\mathrm{ng} / \mathrm{mL}$ died. Moreover, plasma IL-6 peak levels were significantly higher in nonsurvivors compared to survivors. These IL-6 data are consistent with earlier reports on the involvement of IL-6 in the pathophysiology of sepsis syndrome $(16,17)$.

For TNF no correlation with mortality was observed, in contrast to previous reports (9-12), but in agreement with others (13). There are several explanations for the inconsistency in TNF data. First, it was reported recently that assays such as used here detect free TNF, whereas other assays detect free TNF as well as the TNF/soluble TNF receptor complex (15). The relative lack of information about the properties of most assays used, complicates comparison of earlier reported TNF data. Second, TNF is only in short intervals present in plasma during sepsis syndrome as was shown in meningococcal sepsis (16) and in studies with experimentally induced sepsis and endotoxemia $(5,19)$. A rapid decrease in circulating TNF levels can be explained by both its short half life and by an active feedback mechanism as reported in endotoxemia, which appeared to be regulated by the hypothalamic adrenal axis $(28,29)$.

Besides TNF, soluble TNF receptors are considered to be involved in inflammation. Soluble TNF receptors, which consist of the proteolytically cleaved extra-cellular part of the TNF cell surface receptor (30), were first detected in urine of febrile patients (31), and later also in urine and plasma of patients with chronic renal failure (32). The shedding of the TNF receptor may function as a protection mechanism against the harmful effects of TNF. Loss of TNF cell surface receptors could lead to a decreased responsiveness of the cell to TNF. In addition, circulating soluble TNF receptor bind TNF with high affinity, resulting in an inhibition of the biological activity of TNF (32). Shedding of TNF receptor has been demonstrated after endotoxin $(19,20)$ and TNF administration (18), therefore soluble TNF receptor levels could reflect a TNF/ endotoxin induced inflammatory response. Since soluble TNF receptor levels show slower kinetics compared to the short-lived elevations in TNF levels, soluble TNF receptor levels could be more useful as a parameter of disease.

Increased soluble TNF receptor levels have been reported in critically ill patients (19), and a positive correlation with mortality has been demonstrated in meningococcaemia (26). The results presented here are in agreement with these data. Although the differences in soluble $75 \mathrm{kD}$ TNF receptor levels did not reach significancy $(P=.06)$, soluble $55 \mathrm{kD}$ TNF receptor peak levels were significantly higher $(\mathrm{P}<.005)$ in nonsurvivors compared to survivors.

However, increased soluble TNF receptor levels have not only been demonstrated in inflammation, soluble TNF receptor levels are also known to be influenced by renal function. Elevated soluble TNF receptor levels were detected in patients with chronic renal failure (32) and a positive correlation with plasma creatinine was demonstrated in patients with different degrees of chronic renal failure (21). Moreover experimental animal data from our laboratory demonstrated a central role for the kidney in the clearance of TNF receptor and TNF/TNF receptor complexes in mice (33). 
In order to investigate whether soluble TNF receptor kinetics in the population studied were influenced by renal function, soluble TNF receptor peak levels were correlated with corresponding plasma creatinine levels. Since long-term hemodialysis patients were excluded from the study, increased plasma creatinine levels were considered to reflect acute renal failure complicating sepsis syndrome. Both soluble $55 \mathrm{kD}$ TNF receptor and soluble $75 \mathrm{kD}$ TNF receptor peak. levels were correlated significantly with corresponding plasma creatinine levels $\left(r^{2}=.60 ; \mathrm{P}<.0001\right.$ and $r^{2}=.40 ; \mathrm{P}<.001$, respectively). In contrast, TNF $\left(r^{2}=.05 ; \mathrm{P}=.25\right)$ and $\mathrm{IL}-6\left(r^{2}=.17 ; \mathrm{P}<.05\right)$ correlated poorly with plasma creatinine. In long-term hemodialysis patients $(n=4)$, which were excluded from this study, high soluble TNF receptor levels were detected even before sepsis syndrome was diagnosed $(17.3 \pm 0.8 \mathrm{ng} / \mathrm{mL}$ and $12.5 \pm 0.4 \mathrm{ng} / \mathrm{mL}$ for soluble $55 \mathrm{kD}$ and $75 \mathrm{kD}$ TNF receptor, respectively). Although soluble TNF receptor peak levels were high in the excluded patients, 3 out of 4 patients did survive.

Acute renal failure is a severe complication of sepsis and plays an important role in the mortality due to septic shock and multiple organ failure (34). In the present study, the positive correlation between acute renal failure, as assessed by plasma creatinine, and mortality was confirmed (Table 3). Plasma creatinine peak levels were significantly higher in nonsurvivors compared to survivors $(\mathrm{P}<.001)$. Since the kidney was reported to play an important role in soluble TNF receptor clearance, impaired renal function. will lead to the accumulation of these proteins in plasma. This is supported by the demonstrated positive correlation between plasma creatinine and soluble TNF receptor levels. Moreover the correlation of soluble TNF receptor levels with plasma creatinine was more pronounced than the correlation with mediators, such as TNF and IL-6, involved in the pathophysiology of sepsis syndrome (data not shown). The present data strongly suggest that increased soluble TNF receptor levels do not directly reflect inflammatory state, but merely the degree of renal failure.

The physiological role of increased soluble TNF receptor levels in sepsis syndrome is not yet resolved. When sepsis is complicated by an impaired renal function, a decreased clearance of both soluble TNF receptor and TNF/soluble TNF receptor complexes will lead to increased plasma levels. Although TNF complexed with the receptor is biologically inactive, such complexes may serve as a "slow release reservoir" of biologically active TNF (35). On the other hand, pre-existing increased soluble TNF receptor levels, may mitigate the impact of over-production of TNF in patients suffering from severe infections.

In conclusion, soluble TNF receptor levels correlated with outcome as well as with plasma creatinine levels. The data presented suggest that, in the ICU patients studied, increased soluble TNF receptor levels do not directly reflect inflammation, but appear to be the result of renal failure complicating sepsis syndrome and are likewise correlated with mortality. The usefulness of soluble TNF receptor levels as a parameter of disease is therefore limited. The clinical importance of elevated soluble TNF receptor levels remains to be elucidated. 


\section{References}

1. Cerami, A., Y. Ikeda, N. Le Trang, et al. Weight loss associated with an endotoxin-induced mediator from peritoneal macrophages: the role of cachectin (tumor necrosis factor). Immunol. Lett. 1985;11:173-177.

2. Suffredini, A.F., R.E. Fromm, M.M. Parker, et al. The cardiovascular response of normal humans to the administration of endotoxin. N. Engl. J. Med. 1989:321:280-287.

3. Giroir, B.P. Mediators of septic shock: New approaches for interrupting the endogenous inflammatory cascade. Crit. Care. Med. 1993;21:780-789.

4. Tracey, K.J., B. Beutler, S.F. Lowry, et al. Shock and tissue injury induced by recombinant human cachectin. Science 1986;234:470-474.

5. Michie, H.R., K.R. Manogue, D.R. Spriggs, et al. Detection of circulating tumor necrosis factor after endotoxin administration. N. Engl. J. Med. 1988;318:1481-1486.

6. Beutler, B., I.W. Milsark, A. Cerami. Passive immunization against cachectin/tumor necrosis factor protects mice from lethal effect of endotoxin. Science 1985:229:869-871.

7. Tracey, K.J., Y. Fong, D.G. Hesse, et al. Anti-cachectin/TNF monoclonal antibodies prevent septic shock, during lethal bacteraemia. Nature 1987;330:662-664.

8. Echtenacher, B., W. Falk. D.N. Mannel, et al. Requirement of endogenous tumor necrosis factor/cachectin for recovery from experimental peritonitis. J. Immunol. 1990;145:3762-3766.

9. Marks, J.D., C.B. Marks, J.M. Luce, et al. Plasma tumor necrosis factor in patients with septic. shock. Mortality rate, incidence of adult respiratory distress syndrome, and effects of methylprednisolone administration. Am. Rev. Respir. Dis.1990;141:94-97.

10. Damas, P., A. Reuter, P. Gysen, et al. Tumor necrosis factor and interleukin-1 serum levels during severe sepsis in humans. Crit. Care. Med. 1989:17:975-978.

11. Debets, J.M., R. Kampmeijer, M.P. van der Linden, et al. Plasma tumor necrosis factor and mortality in critically ill septic patients. Crit. Care. Med. 1989:17:489-494.

12. Waage, A., A. Halstensen, T. Espevik. Association between tumour necrosis factor in serum and fatal outcome in patients with meningococcal disease. Lancet 1987;1:355-357.

13. Hamilton, G., S. Hofbauer, B. Hamilton. Endotoxin, TNF-alpha, Interleukin-6 and parameters of the cellular immune system in patients with intraabdominal sepsis. Scand. J. Infect. Dis. $1992 ; 24: 361-368$.

14. Fischer. Influence of an anti-tumor necrosis factor monoclonal antibody on cytokine levels in patients with sepsis. Crit. Care. Med. 1993;21:318-327.

15. Engelberts, I., S. Stephens, G.J. Francot, et al. Evidence for different effects of soluble. TNF-receptors on various TNF measurements in human biological fluids [iletter]. Lancet 1991;338:515-516.

16. Waage, A., P. Brandizaeg, A. Halstensen, et al. The complex pattern of cytokines in serum from patients with meningococcal septic shock. Association between interleukin 6 , interleukin 1, and fatal outcome. J. Exp. Med, 1989;169:333-338.

17. Hack, C.E., E.R. de Groot, B.R.J. Felt, et al. Increased plasma levels of interleukin-6 in sepsis. Blood 1989;74:1704-1710.

18. Lantz, M., S. Malik, M.L. Slevin, et al. Infusion of tumor necrosis factor (TNF) causes an increase in circulating TNF-binding protein in humans. Cytokine 1990;2:402-406.

19. van Zee, K.J., T. Kohno, E. Fischer, et al. Tumor Necrosis Factor soluble receptors circulate during experimental and clinical inflammation and can protect against excessive Tumor Necrosis Factor-alpha in vitro and in vivo. Proc. Natl. Acad. Sci. USA 1992;89:4845-4849.

20. Spinas, G.A., U. Keller, M. Brockhaus. Release of soluble receptors for tumor necrosis factor (TNF) in relation to circulating TNF during experimental endotoxinemia, J. Clin. Invest. 1992;90:533-536. 
21. Brockhaus, M., Y Bar-Khayim, S. Gurwicz, et al. Plasma tumor necrosis factor soluble receptors in chronic renal renal failure. Kidney Int. 1992;42:663-667.

22. Knaus, W.A., E.A. Draper, D.P. Wagner, et al. APACHE II: A severity of disease classification system. Crit. Care. Med. 1985;13:818-829.

23. Elebute, E.A., H.B. Stoner. The grading of sepsis. Br. J. Surg. 1983;70:29-31.

24. Bone, R.C. Sepsis, the sepsis syndrome, multi-organ failure: a plea for comparable definitions [editorial]. Ann. Intern. Med. 1991;114:332-333.

25. Engelberts, I., A. Moller, G.J. Schoen GJ, et al. Evaluation of measurement of human TNF in plasma by ELISA. Lymphokine Res. 1991:10:69-76.

26. Girardin, E., P. Rouxlombard, G.E. Grau, et al. Imbalance between tumour necrosis factor-alpha and soluble TNF receptor concentrations in severe meningococcaemia. Immunology 1992;76:20-23.

27. Larsen, K. Creatinine assay by a reaction-kinetic approach. Clin. Chem. Acta. 1972;41:209217.

28. Bertini, R., M. Bianchi, P. Ghezzi. Adrenalectomy sensitizes mice to the lethal effects of interleukin 1 and tumor necrosis factor. J. Exp. Med. 1988;167:1708-1712.

29. Zuckerman, S.H., J. Shellhaas, L.D. Butler. Differential regulation of lipopolysaccharide-induced interleukin I and tumor necrosis factor synthesis: effects of endogenous and exogenous glucocorticoids and the role of the pituitary-adrenal axis. Eur. J. Immunol. 1989;19:301-305.

30. Porteu, F., M. Brockhaus, D. Wallach, et al. Human neutrophil elastase releases a ligand-binding fragment from the 75-kDa tumor necrosis factor (TNF) receptor. Comparison with the proteolytic activity responsible for shedding of TNF receptors from stimulated neutrophils. J. Biol. Chem. 1991:266:18846-18853.

31. Seckinger, P., S. Isaaz, J.M. Dayer. A human inhibitor of tumor necrosis factor alpha. J. Exp. Med. 1988:167:1511-1516.

32. Peetre, C., H. Thysell, A. Grubb, et al. A tumor necrosis factor binding protein is present in human biological fluids. Eur. J. Haematol. 1988;41:414-419.

33. Bemelmans, M.H.A., D.J. Gouma, W.A. Buurman. Influence of nephrectomy on tumor necrosis factor clearance in a murine model. J. Immunol. 1993:150:2007-2017.

34. Manship, L., R.D. McMillin, J.J. Brown. The influence of sepsis and multisystem organ failure on mortality in the surgical intensive care unit. Am. J. Surg. 1984;50:94-101.

35. Aderka, D., H. Engeimann, Y. Maor, et al. Stabilization of the bioactivity of tumor necrosis factor by its soluble receptors. J. Exp. Med. 1992;175:323-329. 


\section{Chapter 11 \\ SUMMARY / SAMENVATTING}

\section{Summary}

It has been recognized that surgery in patients with obstructive jaundice is associated with a high morbidity and mortality. Despite various preoperative therapeutic treatments, performed to reduce the increased risk of complications, the morbidity remains relatively high. Especially infectious complications are a major drawback for surgical procedures in these patients. Although various explanations for this phenomenon have been put forward, the definitive solution to the pathophysiological abnormalities has not yet been found. The aim of this thesis was to further unravel the pathophysiology underlying the complications observed in obstructive jaundice.

In Chapter 1 , an introduction is given of inflammation in general and more specifically of inflammatory derangements during obstructive jaundice. The underlying mechanism of these derangements is still unclear and the discovery of cytokines has offered new tools to elucidate the pathophysiology of inflammation. Especially the inflammatory cytokines IL-6, TNF and the two soluble TNF receptors were considered to be important mediators of the inflammatory response. IL-6 is a cytokine that is normally not detectable in the circulation. However, during trauma or inflammation, a strong increase in IL-6 levels is observed. TNF is shown to be involved in several diseases, especially in the inflammatory diseases and the soluble TNF receptors are considered to be involved in regulation of these TNF levels. These cytokines were particularly of interest since one of the inducers of these inflammatory cytokines, endotoxin, was reported to be present in the circulation of jaundiced patients and animals.

The possible role of the cytokines IL-6, TNF and the soluble TNF receptors in inflammatory diseases and in obstructive jaundice is discussed.

An outline of the experiments which were performed to elucidate the problems put forward in the aim of the study and a discussion of these experiments is presented in Chapter 2. Moreover, recent techniques developed in the laboratory which enabled the studies reported are described. These include the TNF measurement in mice using an ELISA and a bio-assay, the sTNFR measurement in mice using an ELISA, and the studies with the ${ }^{125}$ I-labelled TNF and sTNFR. The ELISA used was shown to recognize "total" TNF. This includes both biologically active TNF and TNF which is not biologically but immunologically detectable. Since the bio-assay measured only bioactive TNF, it was possible to compare biologically active as well as immunologically detectable TNF in the circulation during obstructive jaundice. In addition, the role 
of both soluble TNF receptors is discussed and a detection method developed for these TNF receptors is presented.

Furthermore, the pitfalls of TNF measurements are discussed shortly. It is explained that TNF can be present in the circulation in a biologically active form and in an biologically inactive form, the latter being immunologically detectable. It is shown that some assays measure bioactive TNF, while others detect bioactive as well as bioinactive TNF ("total" TNF or immunologically detectable TNF). Since it is not always clear which assay is used, comparison of data from different research groups remains difficult.

In Chapter 3, experiments are reported that describe the presence of $\mathrm{L}-6$ and TNF in the sera of mice with an experimental biliary obstruction (BDL). Following the surgical trauma, a rapid increase in circulating $\mathrm{IL}-6$ is observed. Thereafter, a slow decrease is observed. However, while IL-6 levels in sham operated mice decreased after the operation, IL-6 levels in BDL mice show a second increase after approximately 12 days. Further, the data demonstrate that TNF is present in the circulation of BDL mice. This in contrast to sham mice in which no circulating TNF could be detected. Cytokine production by macrophages of BDL mice in response to LPS was significantly higher compared to cytokine production by macrophages of sham mice, which is indicative for the inflammatory status present in these mice.

The results indicate that during biliary obstruction an inflammatory reaction is present which is reflected by the presence of circulating inflammatory cytokines IL-6 and TNF and by activated macrophages.

In Chapter 4, a model of temporary normothermic bilateral renal ischemia was used to evaluate mortality after surgery in obstructive jaundice. This trauma model was originally described by Zager and later also used by Maessen and Greve. Maessen et al. showed that ischemic injury to the kidneys was exacerbated by endotoxemia and showed that TNF played an important role in this mechanism. Since TNF and endotoxin are present in mice with biliary obstruction, this model was used to investigate whether surgery in obstructive jaundice was accompanied by an increased mortality. Moreover, this model was also used to investigate the effectiveness of several interventions before surgery in obstructive jaundice.

The data show that bilateral renal ischemia results in increased levels of circulating TNF and a mortality of approximately $50 \%$. Since TNF is suggested to play an important role in the observed mortality, the effect of anti-TNF treatment was tested. Anti-TNF treatment by a monoclonal anti-TNF antibody reduced circulating TNF levels, but failed to reduce the mortality. This was also the case for pentoxifylline, a known TNF inhibitor. Only lactulose resulted in a significant reduction of mortality, although the reduction in TNF was not as impressive as after anti-TNF treatment. Despite the fact that TNF is an important cytokine in several diseases, these results suggest that TNF is not the only mediator involved. Other still unknown factors, which are affected by lactulose, are supposedly also involved. 
Experiments on the nature of TNF in obstructive jaundice are presented in Chapter 5. Moreover, the presence of soluble TNF receptors (sTNFR) in the circulation of these mice was studied with ELISA's developed for this purpose. The data reveal that TNF is predominantly present in the circulation of jaundiced mice in a biologically inactive form. This biological inactivity is probably achieved, at least partially, because the increased levels of TNF are accompanied by increased levels of both STNFR, which are sufficient to prevent the presence of bioactive TNF in the circulation.

Surgical trauma in biliary obstructed mice was accompanied by a high mortality and high TNF levels as is shown in Chapter 4. In Chapter 5, it is shown that this TNF is not biologically active. Moreover, such a trauma is accompanied by a strong increase in the levels of both sTNFR. Comparison of the sTNFR after the operation between the survivors and non-survivors showed that the STNFR levels in the survivors were significantly lower than those of non-survivors.

The results of these experiments indicate that obstructive jaundice is accompanied by inflammation reflected by the presence of circulating TNF. However, this TNF is not biologically active, probably because of inactivation by soluble TNF receptors. After a surgical trauma, circulating STNFR rather than TNF are shown to correlate well with mortality in these mice.

The experiments of the previous Chapters reveal that TNF is present in bioactive as well as immunologically detectable form and it is suggested that sTNFR are important for inactivation of TNF. Moreover, previous reports suggest that TNF and sTNFR are removed from the circulation by the kidneys. Therefore, in Chapter 6, the role of the kidney in clearance of TNF is investigated. Moreover, the nature of TNF (biologically active or immunologically detectable) after LPS injection is evaluated. It is shown that the kidney is the most important organ for TNF clearance. Furthermore, the data reveal that circulating TNF is present in two forms, a biologically active form and an immunologically detectable form. While the removal of biologically active TNF in mice is independent of renal function, the data show that immunologically detectable TNF is removed more slowly from the circulation in nephrectomized mice. In addition, the studies using radiolabelled TNF strongly suggest that sTNFR-P75 rather than $\mathrm{STNFR}$ P55 is involved in inactivation and clearance of TNF from the circulation.

While in Chapter 6, the attention is focussed on TNF and its clearance, in Chapter 7. the clearance of sTNFR from the circulation is studied. The nephrectomy studies show that the kidney is also a very important organ for clearance of both soluble TNF receptors from the circulation. The data show that removal of the kidneys leads within minutes to increased STNFR levels in the circulation. However, after several hours, despite absence of both kidneys, the body is capable of installing a new equilibrium leading to plateau levels of soluble TNF receptors, although these plateau levels are maintained at the expense of higher serum levels. These results suggest that sTNFR clearance is also regulated by other organs.

The studies using radioactive labelled STNFR-P75 reveal that nephrectomy results in a strongly reduced clearance rate of sTNFR-P75 compared to the control mice and 
support therefore the importance of the kidney for clearance. The distribution patterns after ${ }^{125}$ I-sTNFR-P75 injection are also in line with the fact that the kidney is an important clearance organ since major amounts of radioactivity are found in the urine. Next to the kidney, other organs, such as liver, spleen and lungs are also involved in sTNFR clearance.

While the clearance and the function of both soluble TNF receptors was studied extensively in the previous Chapters, agents responsible for the release of soluble TNF receptors in several disease states remain unclear. Therefore, the release of sTNFR in a murine model was studied in Chapter 8 and 9 by triggering this, release via different pathways. The results demonstrate that increased levels of sTNFR in vivo can be induced by endotoxin as well as by human or murine TNF. Nevertheless, pretreatment of the mice injected with endotoxin with anti-TNF antibodies still results in increased sTNFR levels while TNF is hardly measurable. Pretreating the mice with an anti-IFN $\gamma^{\prime}$ antibody reveal that despite a clear TNF reducing effect, the effect on sTNFR levels is less pronounced. LIF treatment reduces only sTNFR-P55 levels together with TNF levels while sTNFR-P75 are unaffected. While IL-1 receptor antagonist (IL-1ra) pretreatment can prevent mortality after a lethal endotoxin injection, treating the mice with an IL-Ira has no effect whatsoever on TNF or sTNFR levels. The conclusion of these experiments is that although TNF, IFN- $\gamma$, LIF and IL- 1 are important cytokines especially in regulation of mortality after endotoxin injection, they do not seem to be of ultimate importance in regulation of sTNFR levels.

Since in diseases where T-cellular processes are involved such as in rheumatoid arthritis TNF is present in the circulation, it is studied in Chapter 9 whether T-cell activation in an experimental model also results in the release of sTNFR. To this end, mice were injected with a monoclonal antibody directed against the murine CD3 molecule. The data show that besides LPS and TNF also T-cell activation by anti-CD3 is capable of inducing the release of both sTNFR in the circulation. However, the kinetics of LPS induced sTNFR release and anti-CD3 induced sTNFR release are clearly different. After T-cell activation, peak levels of sTNFR-P55 are reached much later compared to the situation after LPS injection.

Investigation of the role of TNF and IFN- $\gamma$ revealed that mAb's against these cytokines reduced TNF as well as sTNFR levels. In clinical situations pentoxifylline and steroids are used to prevent the anti-CD3 induced side effects. Therefore, the effect of these agents on sTNFR levels were studied. The data obtained show that both agents reduce TNF and sTNFR-P55 levels without affecting sTNFR-P75 levels.

These results suggest that also T-cellular activation by an anti-CD3 mA b is capable of inducing the release of both sTNFR. Although the cytokines tested seem to be involved in this mechanism, none of them seems to be exclusively responsible for the increase in STNFR levels.

The results of the previous Chapters showed that inflammation is accompanied by TNF, sTNFR and IL-6 release. Moreover, the kidneys are shown to be of major 
importance for clearance of TNF and sTNFR. Therefore, in the last Chapter, cytokine levels of IL-6, TNF, and sTNFR together with the renal function were monitored in septic patients with positive blood cultures. The data revealed that the amount of circulating IL-6 as well as levels of both sTNFR correlated with mortality. This was in contrast to circulating TNF which showed no correlation with mortality. A possible explanation for the fact that TNF reveals no correlation with mortality could be the short $t_{1 / 2}$ of TNF and the rapid inactivation of the TNF molecule when present in the circulation. Moreover, TNF production is not a continuous process.

However, sTNFR levels as expected correlated also strongly with creatinine. On its turn, creatinine showed a good correlation with mortality, a fact which is known for a period of time. These data show that increased cytokine levels are present in septic patients. Moreover, increased sTNFR levels are, at least partially, the result of a decreased renal function and are likewise correlated with mortality.

These results show that cytokine regulation in experimental animals and in septic patients is essentially the same. Moreover, as in mice, the kidney seems to be an important organ for STNFR clearance in these patients. This leeds to the suggestion that the pathophysiology underlying cytokine release in patients and experimental animals is similar. 


\section{Samenvatting}

Het is bekend dat chirurgische procedures in patienten met obstructie icterus gepaard gaan met een hoge morbiditeit en mortaliteit. Ondanks verschillende preoperatieve therapeutische voorzorgsmaatregelen gericht op verlaging van deze complicaties, blijft de morbiditeit relatief hoog. Met name de infectieuze complicaties zijn een oorzaak voor de terughoudendheid voor chirurgische procedures bij deze patienten. Hoewel dit probleem reeds vele jaren bekend is, is de oplossing voor de pathofysiologische afwijkingen die hiermee verbonden zijn nog steeds niet gevonden. Het doel van dit proefschrift is de verschillende pathofysiologische mechanismen die ten grondslag liggen aan deze morbiditeit en mortaliteit, verder te ontrafelen.

In hoofdstuk 1 wordt een introductie gegeven over ontsteking in het algemeen en over de meer specifieke onstekingsafwijkingen die optreden tijdens afsluiting van de galwegen (obstructie icterus) in patiënten. De onderliggende oorzaken van deze afwijkingen zijn nog steeds niet duidelijk. De ontdekking van de cytokines, kleine hormoonachtige eiwitten die een belangrijke rol spelen bij ontstekingsreacties, bood een nieuwe mogelijkheid om deze afwijkingen verder te ontrafelen. Met name de inflammatoire cytokines Interleukine-6 (IL-6), Tumor Necrosis Factor (TNF) en de twee oplosbare TNF-receptoren werden beschouwd als zeer belangrijke cytokines in dit proces. IL-6 is een cytokine dat normaal niet of nauwelijks meetbaar is in de circulatie. Echter, tijdens trauma of gedurende ontstekingsprocessen wordt een sterke stijging gezien van dit cytokine in de circulatie.

TNF wordt aangetroffen in de circulatie tijdens verschillende ziektes, met name tijdens inflammatoire ziektes. De oplosbare TNF receptoren op hun beurt worden beschouwd als regulatoren van de hoeveelheden van TNF in de circulatie, omdat ze door binding aan het TNF molecuul, TNF kunnen inactiveren.

Onze interesse ging uit naar deze cytokines omdat endotoxine (LPS), een van de veroorzakers van deze inflammatoire cytokines, aanwezig is in de circulatie van patiënten met obstructie icterus en dieren met een experimentele afsiuiting van de galwegen. In Hoofdstuk 1 wordt de mogelijke rol van de cytokines IL-6, TNF en de oplosbare TNF receptoren tijdens inflammatie en obstructie icterus besproken.

In hoofdstuk 2 wordt er een beschrijving gegeven van de experimenten die uitgevoerd zijn om de in de inleiding besproken vragen te beantwoorden. Aansluitend hieraan worden de resultaten van de proeven besproken. Bovendien worden de technieken die bij deze experimenten in het laboratorium gebruikt zijn beschreven. Hieronder vallen de TNF meting in de circulatie van de muizen met behulp van een Enzyme Linked Immunosorbent Assay (ELISA) en een bioassay. Van de ELISA is aangetoond dat deze assay de "totale" hoeveelheid TNF meet. Hieronder vallen niet alleen het biologisch actieve TNF, maar ook het TNF dat alleen immunologisch detecteerbaar is. Gezien het feit dat de bioassay alleen vrij bioactief TNF kan meten, was het mogelijk met deze twee assays de spiegels van het immunologisch en het biologisch actieve TNF te 
vergelijken tijdens obstructie icterus. Naast de TNF meting wordt ook de meting van de oplosbare TNF receptoren besproken.

Om de regulatie van TNF en de oplosbare TNF receptoren te onderzoeken, zijn deze eiwitten radioactief gelabeld en aansluitend geïnjecteerd.

Omdat de TNF assay een aantal problemen kent, zijn deze kort aangestipt in dit hoofdstuk. Sommige assays herkennen alleen biologisch actief TNF. Andere assays herkennen ook het TNF molecuul dat geinactiveerd is en daarom immunologisch detecteerbaar wordt genoemd. Gezien het feit dat het niet altijd duidelijk is welke assays gebruikt zijn en dus welk TNF is onderzocht, is het moeilijk verschillende artikelen met elkaar te vergelijken.

In hoofdstuk 3 zijn de metingen beschreven van de cytokines IL-6 en TNF in de circulatie van muizen met een experimentele afsluiting van de galwegen.

De data laten zien, dat er binnen 1-2 uur na de operatie een stijging te zien is van het circulerende IL-6. Na een piek na ongeveer 3 uur wordt er een snelle daling gezien. In tegenstelling tot sham geopereerde muizen waarin de $I L-6$ spiegels blijven dalen, wordt er in de groep met een galwegafsluiting een tweede stijging gezien na 12 dagen. Voorts laten de resultaten zien dat TNF wordt aangetroffen in de circulatie van muizen met een galwegafsluiting, terwijl in de sham geopereerde muizen geen TNF gemeten wordt. Om te onderzoeken of de macrofagen van galweggeobstrueerde muizen in een geactiveerde toestand waren is de cytokine produktie gemeten, zowel spontaan als na stimulatie. De data laten zien dat de macrofagen van de galweggeobstrueerde muizen spontaan reeds veel meer cytokines (zowel IL-6 als TNF) produceren en dat dit verschil in cytokine spiegels ook na stimulatie met bijvoorbeeld endotoxine aanwezig blijft.

Deze resultaten suggereren dat er tijdens afsluiting van de galwegen een ontstekingsreactie aanwezig is hetgeen wordt bevestigd door de verhoogde cytokine spiegels in de circulatie en door de aanwezigheid van geactiveerde macrofagen.

In hoofdstuk 4 wordt een model van tijdelijke normotherme bilaterale nierischemie gebruikt om de mortaliteit na een chirurgisch trauma bij obstructe icterus te evalueren. Dit model was oorspronkelijk beschreven door Zager en later ook gebruikt door Maessen en Greve. Maessen toonde aan dat een ischemische beschadiging van de nier en mortaliteit werden verhoogd door toediening van endotoxine en dat TNF daarbij een rol speelde. Omdat galwegafsluiting gepaard gaat met de aanwezigheid van TNF en endotoxine in de circulatie, werd er in dit model bekeken of de bilaterale ischemie van de nier gepaard gaat met een hoge mortaliteit. Voorts werd dit model gebruikt om de effecten van interventies voor de chirurgische ingrepen te bestuderen. De data laten zien dat er na bovengenoemd trauma een mortaliteit optreedt van zo'n $50 \%$. Voorts blijken de spiegels van TNF sterk te stijgen. Omdat TNF wordt gezien als een cytokine dat potentieel een belangrijke rol speelt in deze mortaliteit, is het effect van anti-TNF behandeling onderzocht. Behandeling met een monoclonaal antilichaam tegen TNF leidde tot een sterke daling van het circulerende TNF, maar resulteerde niet in een 
daling van de mortaliteit. Dezelfde resultaten werden gezien na toediening van pentoxifylline, een andere bekende TNF remmer. Alleen de toediening van lactulose oraal leidde tot een daling van de mortaliteit en een kleine verlaging van de TNF spiegels. Ondanks het feit dat TNF een belangrijk cytokine is tijdens vele ziektes, suggereren deze data dat TNF zeker niet de enige mediator is in de mortaliteit na chirurgie in muizen met een experimentele afsluiting van de galwegen. Andere nog onbekende factoren die beïnvloed worden door lactulose lijken in deze ook een rol te spelen.

In hoofdstuk 5 worden de resultaten besproken van de experimenten die zijn verricht om te onderzoeken of het TNF dat aanwezig is in de circulatie tijdens obstructie icterus biologisch dan wel immunologisch actief is. Bovendien wordt de aanwezigheid van de oplosbare TNF receptoren bij dit ziektebeeld besproken. De data laten zien dat TNF in de circulatie van muizen met een experimentele galwegafsluiting voornamelijk in de biologisch niet actieve vorm aanwezig is. Deze inactivatie wordt waarschijnlijk deels bereikt door het feit dat verhoogde TNF spiegels gepaard gaan met hoge TNF receptor spiegels. Deze receptoren zijn op hun beurt in staat om het vrijgekomen TNF te inactiveren.

Zoals in Hoofdstuk 4 is beschreven, leidt een chirurgisch trauma bij muizen met een galwegafsluiting tot een hoge mortaliteit en hoge TNF spiegels. In Hoofdstuk 5 wordt er aangetoond dat dit TNF niet biologisch actief is. Naast de TNF stijging wordt er ook een stijging van de spiegels van de oplosbare TNF receptoren gezien. Vergelijking van de spiegels van de oplosbare TNF receptoren tussen de muizen die het trauma overleven en de spiegels van hen die niet overleven, laat zien dat de spiegels in de niet overlevende dieren significant hoger zijn.

De resultaten laten zien dat trauma bij galweggeobstrueerde muizen leidt tot hoge spiegels van biologisch niet actief TNF, waarschijnlijk ten gevolge van inactivatie door oplosbare TNF receptoren. Daarnaast wordt aangetoond dat spiegels van oplosbare TNF receptoren een goede correlatie laten zien met de mortaliteit.

De resultaten van bovenstaande studies laten zien dat TNF aanwezig kan zijn in de circulatie in twee vormen, bioactief en immunologisch detecteerbaar, en dat oplosbare TNF receptoren belangrijk zijn voor inactivatie van TNF. Bovendien zijn er sterke aanwijzingen dat TNF en oplosbare TNF receptoren worden verwijderd uit de circulatie door de nier. Op grond van dit feit is in hoofdstuk 6 de klaring van TNF door de nieren onderzocht. Daarnaast werd er onderzocht of TNF aanwezig na LPS toediening, biologisch actief was.

De data laten zien dat de nier het belangrijkste orgaan is voor TNF klaring. Terwijl de klaring van bioactief TNF onafhankelijk van de nierfuctie verloopt, blijkt immunologisch detecteerbaar TNF veel trager te worden verwijderd na verwijdering van de nieren. Bovendien laten de resultaten met de studie met ${ }^{125} \mathrm{I}$ gelabeld TNF in de muis zien dat de $75 \mathrm{kDa}$ receptor verantwoordelijk is voor inactivatie en klaring van TNF uit de circulatie. 
Terwijl in Hoofdstuk 6 de nadruk ligt op de klaring van TNF, wordt er in Hoofdstuk 7 de klaring van de oplosbare TNF receptoren onderzocht. De resultaten laten zien dat ook de oplosbare TNF receptoren worden geklaard door de nier. Reeds enkele minuten na nefrectomie blijkt er een sterke stijging van de plasma spiegels op te treden van de TNF receptoren, die echter na enige tijd een nieuw plateau bereiken. Deze resultaten suggereren dat er ook andere organen verantwoordelijk zijn voor klaring van de oplosbare TNF receptoren. Dit hernieuwde evenwicht gaat echter gepaard met hogere plamaspiegels.

In aansluiting aan de voorgaande hypothese ondersteunen de resultaten van de labellingsproef het feit dat de $75 \mathrm{kDa}$ receptor de belangrijkste inactivator is van TNF. Het distributie patroon van de gelabelde oplosbare TNF receptor laat zien dat de receptor naast in de nier, ook in de lever, milt en longen kan worden aangetoond.

Hoewel in de vorige Hoofdstukken de functie van de oplosbare TNF receptoren is besproken, blijven de stoffen die verantwoordelijk zijn voor de release van deze receptoren nog onduidelijk. Om deze vraag te beantwoorden is in hoofdstuk 8 en 9 de release van deze receptoren bestudeerd.

De resultaten laten zien dat niet alleen endotoxine (LPS) maar ook humaan of muizen. TNF een stijging in de circulerende spiegels van oplosbare TNF receptoren veroorzaakt. Hoewel anti-TNF behandeling de stijging van de TNF spiegels na een LPS injectie kan voorkomen, blijkt deze behandeling de spiegels van de oplosbare TNF receptoren nauwelijks te beïnvloeden. Hetzelfde geldt eigenlijk voor anti-interferon- $\gamma$ (anti-IFN- $\gamma$ ) behandeling na LPS injectie, hetgeen een daling van de TNF spiegels veroorzaakt, maar nauwelijks effect heeft op de spiegels van oplosbare TNF receptoren. Leukemia Inhibiting Factor (LIF) behandeling heeft alleen een kleine daling van de 55 $\mathrm{kDa}$ receptor tot gevolg zonder dat TNF of de zwaardere receptor worden beïnvloed. Behandeling met een $\mathrm{IL}-1$ receptor antagonist (IL-1 ra) blijkt geen effect te hebben op circulerende TNF spiegels noch op spiegels van de oplosbare TNF receptoren.

Deze resultaten laten zien dat hoewel TNF, IFN- $\gamma$, LIF en IL-1 zijn betrokken bij de LPS geïnduceerde mortaliteit, ze op zich zelf niet cruciaal blijken te zijn.

Omdat in ziekten waarbij $\mathrm{T}$-cellulaire processen zijn betrokken, zoals reumatoide artritis, TNF in de circulatie anwezig was, is er in Hoofdstuk 9 onderzocht of T-cel activatie ook leidt tot een release van de oplosbare receptoren. Daartoe werden muizen geïnjecteerd met een monoclonaal antilichaam (mAb) tegen het muizen $\mathrm{CD} 3$ molecuul. De resultaten laten zien dat naast LPS, ook T-cellulaire activatie leidt tot release van oplosbare receptoren, hoewel er duidelijke kinetiekverschillen aanwezig zijn. Antilichamen tegen TNF of IFN- $\gamma$, gegeven voor een injectie met anti-CD3 blijken zowel TNF als de spiegels van beide TNF receptoren te verlagen. Pentoxifylline en steroiden worden in de kliniek frequent gebruikt om de anti-CD3 geïnduceerde morbiditeit te voorkomen. Vanwege dit feit zijn beide stoffen ook getest in het anti-CD3 model. Beide stoffen verlagen TNF en de $55 \mathrm{kDa}$ receptor zonder de $75 \mathrm{kDa}$ receptor te beïnvloeden. 
Deze data suggereren dat naast LPS ook T-cel activatie door anti CD3 leidt tot de release van oplosbare TNF receptoren. Hoewel de geteste cytokines een rol spelen in dit mechanisme, lijkt noch TNF, noch IFN- $\gamma$ cruciaal te zijn.

De resultaten van voorgaande Hoofdstukken laten zien dat ontsteking gepaard gaat met verhoogde spiegels van $\mathrm{LL}-6$, TNF en oplosbare TNF receptoren. Bovendien lijkt de nier een belangrijke rol te spelen in de klaring van TNF en de oplosbare TNF receptoren. Daarom zijn in dit laatste Hoofdstuk de spiegels van IL-6, TNF en de oplosbare TNF receptoren onderzocht tezamen met de nierfunctie in septische patiënten met een positieve bloedkweek. De data laten zien dat zowel IL-6 als de oplosbare TNF receptoren een goede correlatie vertonen met mortaliteit, dit in tegenstelling tot TNF. Een mogelijke verklaring voor het feit dat TNF niet correleert met de mortaliteit is de korte halfwaarde tijd van TNF en de snelle inactivatie door onder andere de oplosbare TNF receptoren.

Echter, de oplosbare TNF receptoren correleren ook goed met de nierfunctie, die op zijn beurt ook een sterke correlatie heeft met mortaliteit. De data laten zien dat bewezen sepsis gepaard gaat met verhoogde cytokine spiegels. Voorts blijkt dat verhoogde spiegels van oplosbare TNF receptoren, tenminste gedeeltelijk, het gevolg zijn van de nierfunctie en derhalve als zodanig correleren met mortaliteit. Het andere deel van de stijging van de spiegels van de oplosbare TNF receptoren is waarschijnlijk het gevolg van de inflammatoire reactie.

Deze resultaten laten zien dat de cytokine regulatie in experimentele muizen en in septische patienten in principe identiek is. Bovendien blijkt de nier bij deze patienten, net als bij de muis een belangrijke functie te hebben in de klaring van de sTNFR. Deze gegevens leiden tot de suggestie dat de pathophysiologie die ten grondslag ligt aan de cytokine release in patienten en experimentele dieren gelijk is. 


\section{Dankwoord}

Zoals altijd volgt er aan het einde van een proefschrift een dankwoord. Dit is niet meer dan logisch, want zonder bepaalde personen zou dit proefschrift niet gerealiseerd hebben kunnen worden.

Als eerste wil ik mijn co-promotor bedanken, Wim Buurman. Beste Wim, je uitspraken "fluitje van een fietsbel, heb ik al duizend keer gedaan" betekenden meestal weer een maand of drie hard werken. Je uitgesproken gedrevenheid en enthousiasme (ook s'avonds en in het weekeinde) zorgde er echter voor dat ik, ook als het soms tegen zat, altijd weer de draad oppakte. Tijdens onze werkbesprekingen bleek dat je niet alleen op je eigen vakgebied veel kennis bezat, maar ook op andere gebieden, hetgeen de besprekingen enigszins verlengde (en menig sterk verhaal over de ifel deed vliegen). Beste Wim, je hulp was van onschatbare waarde en ik hoop nog lang met je te kunnen blijven samenwerken.

Dirk Gouma, als student ben ik bij je begonnen en heb je me lekker gemaakt voor de chirurgie. Na mijn studie ben ik daarom begonnen met het verwezenlijken van de droom chirurg te worden. Voorafgaand aan mijn opleiding heb ik eerst deze promotie afgerond. Voor het schrijven van de artikelen hebben we samen menig heuveltje beklommen, zowel letterlijk als figuurlijk en je kritische opmerkingen bleken zeer waardevol bij het tot stand komen van dit proefschrift. Hopelijk kunnen we in de toekomst nog eens samen "aan tafel" staan.

Jan-Willem Greve, in het begin van mijn promotic hebben we vaak nieuwe experimenten besproken in "ons huis", waarvoor mijn dank (ook voor het huis).

Zonder de mensen van het lab Heelkunde was deze promotie niet tot een goed einde gekomen. Allereerst mijn kamergenoten: Gaby, als ik in technische problemen zat met elisa's of andere zaken was je er altijd om de helpende hand te bieden. Monique, de gedurende de laatste maanden, toen ik met mijn proefschrift bezig was, heb je me geholpen met het uitwerken van de receptor elisa's, hetgeen vaak een ondankbaar karwei was. Joop, alias lekker, lekker, scrontsch; we wachten nog op het etentje in Brussel. Ivo, we hebben veel lol gehad, vooral het lab-uitje was een succes hetgeen herhaling behoeft. Bas, opvolger van Joop, jij kwam naar het lab juist voordat ik naar de kliniek ging, bedankt voor de gezelligheid.

Maarten Bouma, niet alleen op het lab hebben we veel plezier gehad, ook op de fiets hebben we heel wat kilometertjes gemaakt; alleen leef je voor een "Grunninger" knap bourgondisch.

Jet, Trudy, Mieke, Jeske, Ilse, Mariëlle, Ingeborg, Eckhardt, Berry en Robert, bedankt voor de hulp en de gezellige tijd op het lab. De wetenschappelijke discussies waren altijd zeer verhelderend, de borrels van het lab voor herhaling vatbaar. 
Albert Froon, het laatste hoofdstuk is grotendeels jouw werk waarvoor mijn dank. Komend jaar zullen we elkaar in de kliniek weer tegenkomen.

Cees Dejong, samen zijn we in het BMC begonnen en samen zullen we verder gaan met de opleiding Heelkunde. Eigenlijk is nu alleen het bier een probleem (ik zal er echt beter op letten).

Marian Siep mijn dank voor je secretariële ondersteuning, vooral als de deadlines er weer aan kwamen. Esther ten Hoor, toen het proefschrift ten einde liep, moesten er allerlei zaken op korte termijn geregeld worden, hetgeen je snel en doeltreffend afhandelde.

Mick Deutz, je kritische opmerkingen en adviezen bleken altijd van grote waarde, je statische kennis bleek vaak een uitkomst.

De "lab-buren" Gabrie, Hans, Carlo en Dennis, bedankt voor jullie hulp en gezelligheid.

Karin Scheele, bedankt voor de lay-out van het proefschrift. Ik had er zelf echt geen zin meer in.

De vakgroep Heelkunde, in het bijzonder Prof. Kootstra en Prof. Soeters, wil ik bedanken voor de mogelijkheden die ze hebben geboden om mijn promotie te verwezenlijken.

De Heelkundige assistenten zou ik willen bedanken voor het ontzien van mij, speciaal voor mijn promotie.

Tevens een speciaal woord van dank voor de afdeling CPV onder leiding van Ton van de Boogaard voor de perfecte verzorging van mijn muisjes en konijnen en voor de vele nuttige adviezen. Ondanks alle huisvestingsproblemen wisten jullie ervoor te zorgen dat ik gewoon door kon opereren.

Michel Goldman et Daniel Abramowicz, merci pour m'avoir donné la posibilité de travailler dans votre laboratôire à Bruxelles.

Tevens eeri speciaal woord van dank voor de "echte vrienden" Maupie, L. Claus, BTV, en Zwoelie (de laatste twee tevens paranymf). Nu het proefschrift af is kunnen we eindelijk weer eens samen op vakantie (en krijgen wij natuurlijk de pepermolen weer). Theun en Lianne, bedankt voor ons vakantieverbijif in Frankrijk "dans la Ferté". Het leverde Maya en mij spaarzame momenten van echte ontspanning op tijdens onze promotietijd.

De ouders van Maya, Sam en Thea, bedankt voor de gastvrijheid en de lasagna. Nu we wai meer tijd hebben zal ik niet meer zo hard rijden en zullen we weer wat vaker langs komen.

Tevens wil ik diegenen bedanken die ik vergeten heb hier te vermelden (daar kom je meestal pas achter als het boekje al naar de drukker is).

Aan het einde komen meestal de mensen waarvoor een simpel dankwoord eigenlijk. tekort schiet. Dit geldt voor mijn ouders, Rietje en Leon. Jullie hebben ervoor gezorgd dat een aantal zaken altijd weer geregeld was en jullie stonden altijd klaar met adviezen en hulp voor ons, vooral tijdens de laatste maanden van onze promotie. Zonder jullie was ik nooit zaver gekomen. 
Last but certainly not least, Maya. Allebei hebben we een proefschrift geschreven en ons huishouden was er dan ook naar. De vrije tijd die we hadden was zeer spaarzaam, evenals de vakanties. Ik weet zeker dat het zonder elkaar een stuk moeilijker geweest zou zijn. Nu de promoties achter de rug zijn, kunnen we weer eens gewoon op vakantie en hebben we tenminste weer eens een weekend gewoon vrij. Op naar de volgende uitdaging, de logeerkamer bijvoorbeeld. 


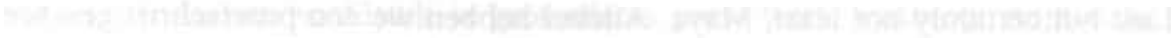

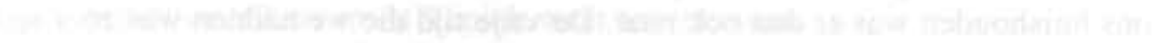

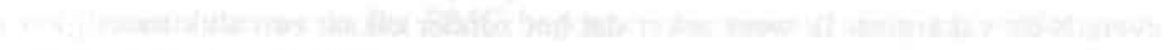

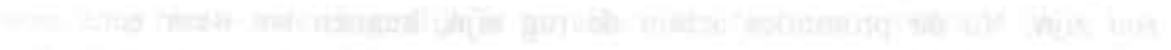

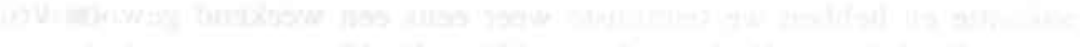




\section{Publications}

During the course of the experimental studies, which are partially presented in this thesis, the following publications were realized.

1. Bemelmans, M.H.A., J.W. Greve, D.J. Gouma, W.A. Buurman. Cytokines Tumor Necrosis Factor and Interleukin-6 in experimental biliary obstruction in mice. Hepatology 1992;15:1132-1136.

2. Bemelmans, M.H.A., D.J. Gouma, J.W. Greve, W.A. Buurman. The effect of anti-TNF treatment on circulating Tumor Necrosis Factor and mortality after surgery in jaundiced mice. Br. J. Surg. 1993; 80:1055-1058.

3. Bemelmans, M.H.A., D.J. Gouma, W.A. Buurman. Influence of nephrectomy on Tumor Necrosis Factor clearance in a murine model. J. Immunol. 1993;150: 2007-2017.

4. Gouma, D.J., J.W. Greve, M.H.A. Bemelmans. Development and reversibility of T lympho-cyte dysfunction in experimental obstructive jaundice. Br.J.Surg. 1991; 78:633 (Letter to the editor).

5. Bemelmans, M.H.A., D.J. Gouma, W.A. Buurman. LPS induced sTNF-Receptor release invivo in a murine model: investigation of the role of TNF, IL-1, LIF, and IFN- $\gamma$. J. Immunol. 1993;151:5554-5562.

6. Froon, A.H.M., M.H.A. Bemelmans, J.W. Greve, C.J.van der Linden, W.A. Buurman. Increased plasma levels of soluble Tumor Necrosis Factor receptors in sepsis syndrome: correlation with plasma creatinine. Crit. Care, in press.

7. Bemelmans, M.H.A., D. Abramowicz, D.J. Gouma, M. Goldman, W.A. Buurman. In vivo T-cell activation by anti-CD3 $\mathrm{mAb}$ induces soluble TNF Receptor release in mice: effects of pentoxifylline, methylprednisolone, antiTNF and anti-IFN- $\gamma$ antibodies. J. Immunol., in press.

8. Bemelmans, M.H.A., J.W. Greve, D.J. Gouma, W.A. Buurman. Increased levels. of TNF and soluble TNF receptors in biliary obstruction in mice; soluble TNF receptors as prognostic factors for mortality. Submitted for publication.

9. Bemelmans, M.H.A., D.J. Gouma, w.A. Buluman. Tissue distribution and clearance of soluble murine TNF receptors in mice. Submitted for publication.

10. Takahashi, N., P. Broukaert, M.H.A. Bemelmans, W.A. Buuman, W. Fiers. Mechanism of induction to Tumor Necrosis Factor (TNF): no involvement of modulators of TNF bioavailability or receptor binding. Cytokine, in press.

11. Steinsham, S., M.H.A. Bemelmans, W.A. Buurman, A. Waage. Granulocytopenia reduces release of soluble. TNF receptor $\mathrm{p} 75$ in endotoxin-stimulated mice: A possible mechanism of enhanced TNF activity. Submitted for publication. 



\section{Curriculum Vitae}

Marc Bemelmans was born on February $7^{\text {th }} 1964$ in Maastricht, The Netherlands. He attended high school in Maastricht, Henric van Veldeke College (Gymnasium B). In 1982 he entered Medical School at the University of Maastricht. From may 1988 until september 1988 he worked as a research fellow at the Department of Surgery, School of Medicine, University of Wisconsin, Madison, USA (head: Prof. dr. F.O. Belzer). He graduated in november 1988. From early 1989 until september 1993 he was a research fellow at the Laboratory of Experimental Surgery, Department of Surgery, Biomedical Center, University of Limburg, Maastricht (head: Dr. W.A. Buurman). During this period the work contained in this thesis was accomplished under the supervision of Dr. W.A. Buurman and Prof. dr. D.J. Gouma. In september 1993 he started his surgical training in the Academic Hospital Maastricht, The Netherlands (head Prof. dr. G. Kootstra). 
Het verschijnen van dit proefschrift werd mede mogelijk gemaakt door de financiële steun van Duphar Nederland B.V., Solvay Duphar B.V., de stichting Dr. Ir. J.H.J. van de Laar, Zyma Nederland B.V., Glaxo B.V, en Nutricia B.V. 

